Florida International University FIU Digital Commons

FIU Electronic Theses and Dissertations

University Graduate School

6-24-2002

\title{
Lumps and balls in high-slump concrete: reasons and remedy
}

Ivan R. Canino-Vazquez

Florida International University

DOI: $10.25148 /$ etd.FI14052558

Follow this and additional works at: https://digitalcommons.fiu.edu/etd

Part of the Civil Engineering Commons

\section{Recommended Citation}

Canino-Vazquez, Ivan R., "Lumps and balls in high-slump concrete: reasons and remedy" (2002). FIU Electronic Theses and Dissertations. 1994.

https://digitalcommons.fiu.edu/etd/1994

This work is brought to you for free and open access by the University Graduate School at FIU Digital Commons. It has been accepted for inclusion in FIU Electronic Theses and Dissertations by an authorized administrator of FIU Digital Commons. For more information, please contact dcc@fiu.edu. 
FLORIDA INTERNATIONAL UNIVERSITY

Miami, Florida

LUMPS AND BALLS IN HIGH-SLUMP CONCRETE:

REASONS AND REMEDY

A thesis submitted in partial fulfillment of the

requirements for the degree of

MASTER OF SCIENCE

in

CIVIL ENGINEERING

by

Ivan R. Canino-Vazquez

2002 
To: Dean Vish Prasad

College of Engineering

This thesis, written by Ivan R. Canino-Vazquez, and entitled Lumps and Balls In HighSlump Concrete: Reasons and Remedy, having been approved in respect to style and intellectual content, is referred to you for judgment.

We have read this thesis and recommend that it be approved.

Luis Prieto-Portar

Nestor Gomez

Irtishad Ahmad, Major Professor

Date of Defense: June 24, 2002

The thesis of Ivan R. Canino-Vazquez is approved.

Dean Vish Prasad

College of Engineering

Dean Douglas Wartzok

University Graduate School

Florida International University, 2002 


\section{DEDICATION}

A man once told me; "The most difficult part of receiving an academic degree, is getting to school." This thesis is dedicated to him, my father; who bestowed upon me the greatest gift of all, an education. Secondly, I dedicate this work to my mother. For never allowing her great love and affection towards me, to hinder her ability to cope with my absence.

Finally, I dedicate this to all those who perished on September 11, 2001 as a consequence of the destruction of the World Trade Towers in New York City. As a Civil Engineer, one is humbled, due to our great civil obligation. Engineers will learn from this catastrophe and underscore our ethical responsibilities to society to built safe infrastructures and cities. The engineering community must improve our work where needed, in order to prevent such devastation from ever happening again. 


\section{ACKNOWLEDGMENTS}

I wish to thank my major graduate professor, Dr. Irtishad Ahmad for all his support during my graduate studies at Florida International University. His input and guidance is greatly appreciated. Also in my committee, Dr. Nestor Gomez and Dr. Luis Prieto-Portar, your draft corrections of my work were very useful. Thank you for your advice and for being in my committee.

My appreciation goes out to Mr. Salman Azhar from Florida International University for helping me conduct the experiments and for providing helpful information. Furthermore, I would like to acknowledge CSR Rinker and their personnel, mainly Mr. Jerry Haught P.E.; as well as the Florida Department of Transportation personnel, Mr. Leigh Markert and Ms. Robbin Dano for their expertise.

Finally, I would like to thank Mr. Richard Gaynor, former director of the National Ready Mix Concrete Association for his previous substantial research, advice, and suggestions for my work. 


\section{ABSTRACT OF THE THESIS \\ by \\ Ivan R Canino-Vazquez \\ Florida International University, 2002 \\ Miami, Florida \\ Professor Irtishad Ahmad, Major Professor}

LUMPS AND BALLS IN HIGH-SLUMP CONCRETE: REASONS AND REMEDY

The objective of this research was to investigate the reason lumps occur in highslump concrete and develop adequate batching procedures for a lumps-free high-slump ready-mix concrete mix used by the Florida Department of Transportation. Cement balls are round lumps of cement, sand, and coarse aggregate, typically about the size of a baseball that frequently occur in high-slump concrete. Such lumps or balls jeopardize the structural integrity of structural members.

Experiments were conducted at the CSR Rinker concrete plant in Miami, Florida, based on a protocol developed by a team of Florida Department of Transportation (FDOT) concrete engineers, Rinker personnel, and Florida International University faculty. A total of seventeen truckloads were investigated in two phases, between April 2001 and March 2002. The tests consisted of gathering data by varying load size, discharge rate, headwater content, and mixing revolutions.

The major finding was that a usual load size and discharge rate, an initial headwater ratio of $30 \%$, and an initial number of revolutions of 100 at 12 revolutions per minute seem to produce a lump-free high-slump concrete. It was concluded that inadequate mixing and batching procedures caused cement lumps. Recommendations regarding specific load size, discharge rates, number of mixing revolutions, and initial water content are made. Clear guidelines for a high-slump concrete batching protocol can be developed, with further testing based on these research conclusions. 
1. INTRODUCTION 1

1.1 PROBLEM STATEMENT 5

1.2 SCOPE AND OBJECTIVES 6

1.3 ORGANIZATION OF THESIS $\quad 8$

2. CONCRETE MIXING TECHNOLOGY; CURRENT STATE OF KNOWLEDGE 9

$\begin{array}{ll}2.1 \text { CURRENT SPECIFICATIONS } & 10\end{array}$

2.2 HIGH-SLUMP CONCRETE 11

$\begin{array}{ll}\text { 2.2.1 Code specifications } & 13\end{array}$

2.3 PROPORTIONING CONCRETE 14

2.4 CONCRETE MIX DESIGN 16

$\begin{array}{ll}2.5 \text { TRUCK MIXER } & 19\end{array}$

2.6 CONCRETE MIXING 25

2.6.1 Mixing codes 26

2.7 PRODUCTION MIXING TECHNIQUES FOR TRUCK MIXED CONCRETE 26

2.8 PRIOR RESEARCH 27

2.8.1 Mixing in a Truck Mixer 28

2.8.2 Avoiding Uniformity Problems in a Truck Mixer 31

2.8.3 CSR Rinker Loading Sequence $\quad 35$

2.9 PROFESSIONAL OPINIONS 36

2.9.1 California Department of Transportation 36

2.9.2 Georgia Department of Transportation 37

2.9.3 Online Concrete Database $\quad 37$

2.10 SPECIFIC PROBLEMS 38 
3. METHODOLOGY 40

3.1 TEST VARIABLES $\quad 40$

3.2 MIX DESIGN 41

3.3 CONCRETE TRUCK MIXER 44

3.4 METHODOLOGY 44

3.4.1 Phase I 46

3.4.2 Phase II 47

3.5 EXPECTED RESULTS 48

4. RESULTS AND ANALYSIS OF FINDINGS 53

4.1 TEST BATCHES/VARIABLES STUDIED 55

4.1.1 Discharge rate 56

4.1.2 Load size $\quad 59$

4.1.3 Headwater content 61

4.1.4 Initial Revolutions 66

4.1.5 Headwater and Initial Revolutions 67

4.2 CEMENT LUMP SAMPLE GRADATIONS 69

4.2.1 Sample Gradations Discussion $\quad 69$

5. DISCUSSION AND CONCLUSIONS 74

$\begin{array}{ll}5.1 \text { DISCUSSION } & 74\end{array}$

5.2 CONCLUSIONS 75

5.3 RESERCH CONTRIBITION/IMPLEMENTATION 77

$\begin{array}{ll}\text { 5.4 FUTURE STUDIES } & 78\end{array}$

$\begin{array}{ll}\text { 6. REFERENCES } & 81\end{array}$

$\begin{array}{llr}7 . & 83\end{array}$ 


\section{LIST OF TABLES}

TABLE

PAGE

3.1 Mix Design for Phase I 42

3.2 Mix Design for Phase II 43

4.1 Test Batch Results 54

4.2 Grading Samples: Percent Passing 70

4.3 Grading Samples: Percent Retained 71 


\section{LIST OF FIGURES}

FIGURE

PAGE

1.1 Concrete in Formwork 3

1.2 Cement Lump or Ball 3

1.3 CSR Rinker Facilities in Miami, Florida 7

$\begin{array}{lll}2.1 & \text { Slump of Concrete } & 12\end{array}$

$\begin{array}{lll}2.2 & \text { CSR Rinker Truck Mixer } & 19\end{array}$

$2.3 \quad$ TMMB Rating Plate 20

2.4 Required Capacity and Approval Metal Plate of a CSR Rinker Truck $\begin{array}{ll}\text { Mixer } & 22\end{array}$

$\begin{array}{lll}2.5 & \text { Truck Mixing Drum Layout } & 24\end{array}$

2.6 Drum Blades 24

$\begin{array}{lll}2.7 & \text { Batching Procedures } & 32\end{array}$

3 Batching Procedure 45

3.1 Concrete Samples 49

3.2 Concrete Cylinder Samples 49

3.3 Concrete Slump Test 50

3.4 Concrete Air Content Test 50

3.5 Concrete Discharge 51

3.6 Discharging Concrete Into Secondary Truck 51

3.7 Concrete Cement Lump Retrieval 52

3.8 Sieving Concrete $\quad 52$

4.1 Ten Inch Cement Lump 55

4.2 Trial A: Discharge Rate 56

4.3 Cement Lumps of $150 \mathrm{lb} / \mathrm{sec}$ Batch 58 
4.4 Cement Lump of $250 \mathrm{lb} / \mathrm{sec}$ Batch 58

4.5 Trial B: Load Size $\quad 59$

4.6 Cement Lumps from 7 cuyd Load 60

4.7 Trial C: Headwater Ratio 61

4.8 Cement Lumps in One Day of Testing of Phase I 63

4.9 Trial D: Headwater Ratio 63

4.10 Cement Lump of 50\% Headwater Ratio and 55 Initial Revolutions in Phase II 65

4.11 Cement Limp of $30 \%$ Headwater Ratio and 55 Initial Revolutions in Phase II 65

4.12 Trial E: Initial Mixing Revolutions 66

4.13 Initial Mixing Revolutions and Headwater Ratio 67

4.14 Grading Sample Weights 69

$\begin{array}{lll}4.15 & \text { Percent Passing } & 71\end{array}$

4.16 Percent Retained 72

4.17 Cement Lumps Composition 73 


\section{CHAPTER 1: INTRODUCTION}

Ready-mix concrete can be produced in large central batching plants that provide good quality control under strict guidelines. These central batching plants mix aggregate, cement, and water to form concrete very effectively. This is because central batching facilities usually have larger mixing blades and higher mixing agitation. These plants can provide good homogeneous concrete in large amounts. One shortcoming central batching plants have, is that they are large and expensive. This is why large batching facilities are not abundant. Moreover, concrete delivery is limited to a specific diameter distance from the plant. Due to this limitation, concrete producers have used other less expensive alternatives to produce and deliver ready-mixed concrete.

One alternative method of producing ready-mix concrete is to batch concrete in truck mixers. The components of concrete are mechanically introduced to the inclined truck drum and are then mixed in the truck. Truck mixing allows the concrete producer to batch concrete of particular requirements for a customer; and increases the range and reliability of the concrete delivery. Contrary to central stationary mixing plants, truck mixers do not have large mixing blades and high mixing capacities. Mixing concrete in a truck is different from mixing it in a central batch plant. Mixing blades in a plant lift and drop the concrete. Width limitations on truck mixers dictate the use of spiral blades that first move the concrete down towards the head end of the drum then back up the central axis towards the discharge end. Therefore, concrete mixed in a truck mixer is normally 
not as uniform as concrete from a central batching plant (Gaynor, 1996). In South Florida, the majority of ready-mix concrete produced is mixed in a truck mixer. Therefore, investigation and research in adequate truck mixing techniques are imperative in this region.

Major customers, such as those in the Florida Department of Transportation (FDOT), have faced problems with the truck mixed high-slump concrete used in drilled shaft. It seems that the concrete is prone to forming cement lumps when batched or mixed in a truck mixer (Figure 1.1). Cement balls are round lumps of cement, sand, and coarse aggregate, typically about the size of a baseball (i.e. 6") (Figure 1.2) (Gaynor, 1996). Mixing usually grinds them up in a 2-inch slump concrete mix, but in high-slump concrete (6 to 8 inches), required for drilled-shafts this does not occur.

A drilled-shaft forms the basis of a structural foundation, or in the case of FDOT a road bridge (deep foundation system for heavy loads). Similar to a footing pile, a drilledshaft supports the load of the structural member above it. Contrary to a pile that is prefabricated and hammered in, a drilled-shaft is constructed on site. A hole is first excavated to meet the dimensions for the drilled-shaft required to support the structure. Then, the steel reinforcement cage is introduced and the concrete is cast. Therefore a concrete with high mobility is required in order to flow through the steel reinforcement and small crevasses in the ground. The water in the concrete is increased to raise its workability. 


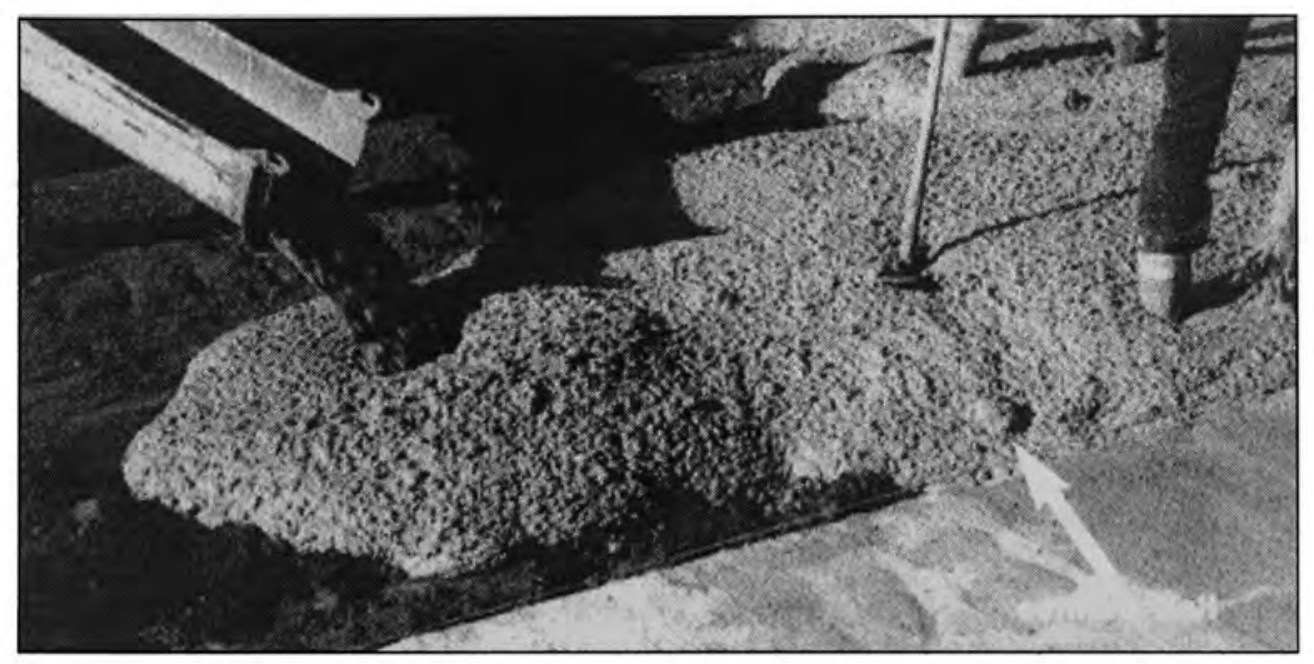

Figure 1.1 Concrete in Formwork (Gaynor, 1996)

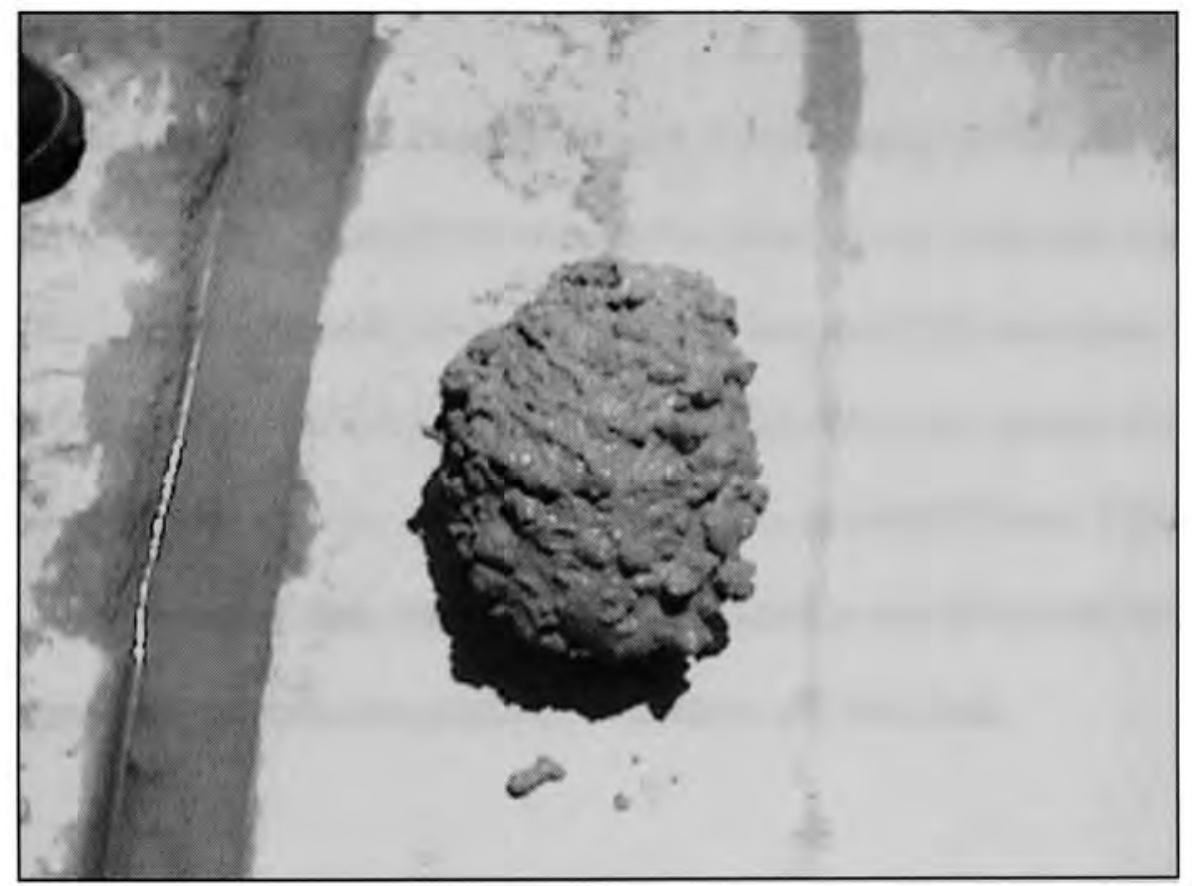

Figure 1.2 Cement Lump or Ball 
Because of the high workability needed in high-slump concrete, a large amount of water is present in the mix and is therefore susceptible to homogeneity problems. "Workability is the property of freshly mixed concrete that determines the ease and homogeneity with which it can be mixed, placed, compacted and finished" (Gambir, 1989). Sometimes the term consistency is used to describe this condition. In general, freshly mixed concrete is plastic or semi-fluid with the consistency of thick mud. However, different degrees of plasticity are needed for different uses of concrete. The consistency of concrete is directly affected by the amount of water in it, better known as the water-cement ratio (if no admixtures are used). The more water in the concrete the more fluid and workable it is. The consistency is often measured by the slump of the concrete. Paving concrete has usually a low-slump (stiff consistency), while drilled-shaft concrete uses a high-slump concrete.

Cement lumps or balls frequently found in high-slump concrete jeopardize the structural integrity of drilled shafts by causing the formation of weakened zones and by increasing the potential for soil intrusion. If cement lumps or balls are found in a batch, the Florida Department of Transportation requires the batch to be rejected (FDOT 346). This creates disruption of work, costly rework, and loss of valuable time. The occurrence of cement lumps in high-slump concrete must be avoided to ensure the best interest of all the parties involved: the concrete producer, contractor, and the client. 


\subsection{PROBLEM STATEMENT}

A thorough investigation needs to be carried out to determine the reasons for lumps and to develop procedures for avoiding the occurrences of lumps and balls in truck-mixed high-slump ready-mixed concrete used to cast Florida Department of Transportation drilled-shafts.

At the moment, no mixing specification for high-slump concrete is available in the United States of America. This may be due to two factors: 1) cement lumps occur in all kinds of concretes, and it is therefore accepted as a common nuisance and removed or sieved while casting; and 2) there has not been much interest by a major organization for a high-slump concrete truck-mixing procedure until now. Normal slump concrete has been extensively researched before and these findings have been applied to concrete batching procedures. Subsequently, FDOT drilled-shaft concrete has been batched using procedures for normal slump concrete. As mentioned earlier these procedures have proved to be inadequate for batching high-slump concrete. An unusually high number of cement lumps have been found in high-slump concrete, to the extent that FDOT is requiring batches having cement lumps to be discarded. Because of the costly consequences of batches being rejected, FDOT is searching for a protocol to mix highslump concrete. 


\subsection{SCOPE AND OBJECTIVES}

The scope of this research is high-slump concrete used for Florida Department of Transportation drilled-shafts mixed in a truck mixer. The objective of this investigation is to develop procedures and batching techniques to produce lumps-free high-slump concrete, by performing extensive field tests batches in a concrete manufacturing facility. The findings of this research will be suggested to the FDOT as a basis that will eventually, after further testing, be used to develop specifications for high-slump concrete mixed in a tuck-mixer. The CSR Rinker plant, in Miami Florida, was selected for this purpose (Figure 1.3). Test batches were tested at this location. These tests involved studies of such variables such as batch size, discharge rate, headwater content, mixing rate, and mixing time.

The concrete mix and its proportions are identical for all batches. Because of a large number of variables present in the manufacturing of concrete and the high cost of each test batch, variables like: 1) the mixing rate and charging rate of the truck mixer drum, 2) the discharge sequence of the materials in to the tuck mixer, 3) the mix design properties, and 4) the mixing equipment or truck are taken as constants. Furthermore in Chapter Two, researches done on some of these variables are included and it would be redundant to test them again. Variables like the mixing sequence of materials have been previously studied and are explained in Chapter 2 (please see Section 2.7). Similarly, the charging and mixing rate of the drum are plant standards used by the concrete manufacturer and remain constant. The same truck is used in all test batches for this 


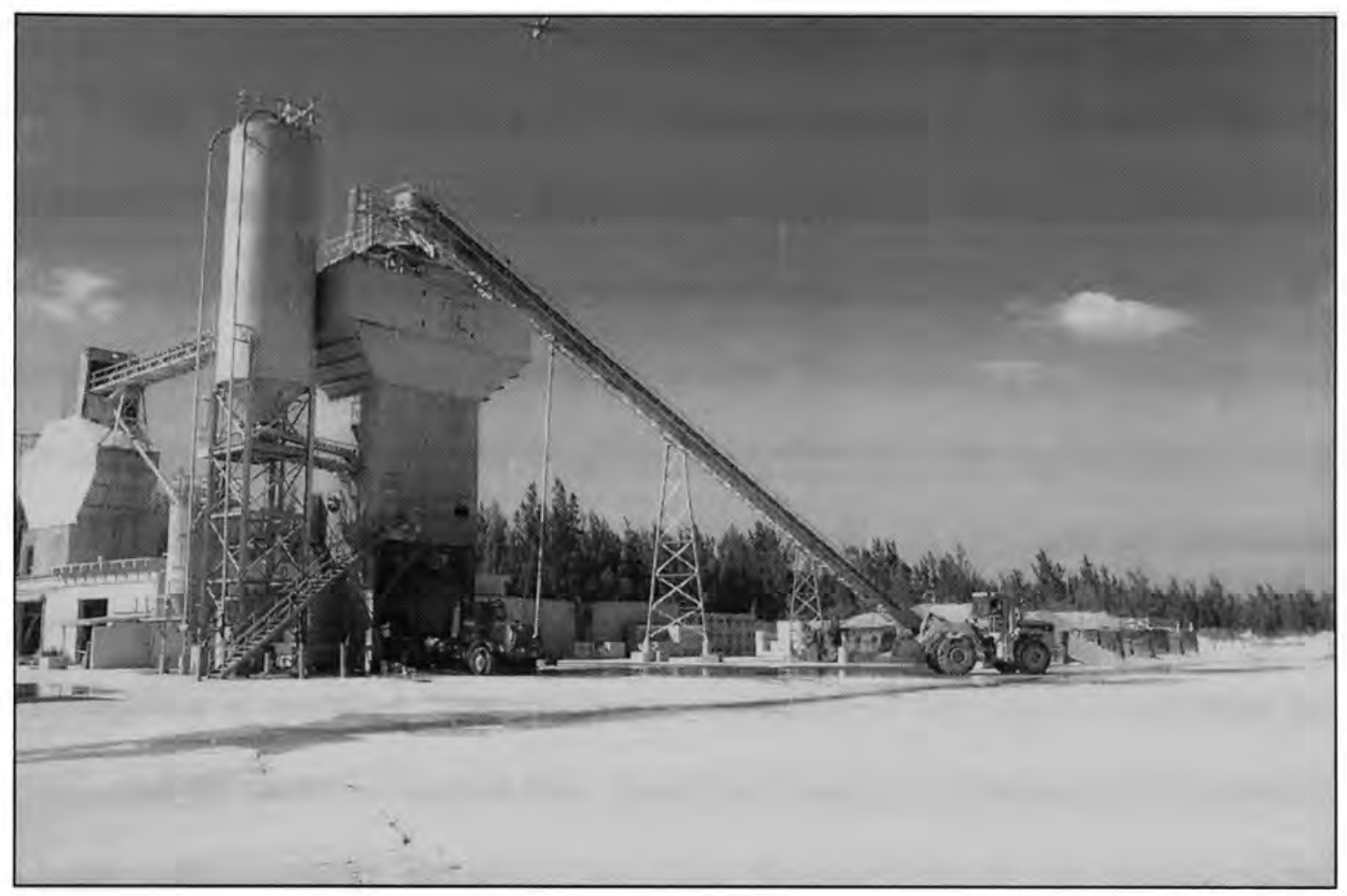

Figure 1.3 CSR Rinker Facilities in Miami, Florida

study, in order to eliminate the equipment condition as a variable. Seven and twentyeight-day compression cylinder tests were preformed to gather data on strength uniformity. A low coefficient of variation among the test batches indicates this. Cement balls are analyzed for gradation and content. The analyzed cement lumps provides a better understanding of their composition. Finally, slump, air entrapment, and temperature data were also collected for each test batch. 


\subsection{ORGANIZATION OF THESIS}

This report is organized in a sequential manner to simplify the reader's comprehension. The study begins with a simple introduction, explaining some concrete basic principles and identifying the problem (Chapter 1). Second, in Chapter 2, the materials and the procedures of batching concrete, their respective codes, and any past research are included. These give insight to the problem and help explain current mixing methods used in the industry. These methods are then incorporated to high-slump concrete whenever possible. Next, Chapter 3 the methodology used to carry out the investigation is described. The project was conducted in two phases to examine the reason and the remedy of cement balls. Results and analysis of findings are discussed in Chapter 4 in two phases. The results from these two phases provide the conclusions and suggestions for the high-slump concrete mix protocol (Chapter 5). Finally, a list of possible ways to expand on this study is given. 


\section{CHAPTER 2}

\section{CONCRETE MIXING TECHNOLOGY; CURRENT STATE OF KNOWLEDGE}

High slump concrete is not an innovation; it has been batched and used extensively. Still, one may think concrete engineers have never paid much attention to it due to the lack of credible research done on the subject. One reason is that cement lumps in concrete are a manufacturing problem born at the mixing plant. In other words, the construction engineer is not responsible for the concrete. The engineer purchases the material as any other product, to suffice structural specifications. If the engineer finds any balls or lumps in the mix, "they are sieved and work is continued" (Markert, 2001). Concrete manufactures are private companies that do not regulate codes, and therefore do not usually conduct research investigations. But, due to their experience, concrete manufactures are the best source of information into the problem. Most available information on the subject comes from small research and professional opinions provided by concrete manufactures and their engineers.

Concrete manufacturers normally use procedures outlined in codes for normal slump concrete and use their own experiences, when varying the amount of water in the batch of high-slump concrete, to incorporate the adequate water content and sequence (Markert, 2001). However, this is proving to be a faulty technique. This seemingly proper batching technique is costing the FDOT too many delays because of the excessive amount of cement lumps found in high-slump concrete. This has leaded the Florida 
Department of Transportation (FDOT) to search for a protocol to mix high-slump concrete used in drilled-shafts in order to have a lumps-free concrete.

By the same token, concrete manufactures believe that producing lumps-free high-slump concrete is achievable. But the primary reason concrete manufacturers do not have a different batching method for high-slump concrete is that they understand that the guidelines will decrease their productivity and increase cost. One can presume that concrete manufacturers think the cost of batching a lumps-free high-slump concrete outweigh the lost revenue and time of rejected batches. The rationale behind their belief could be that a different batching guideline would affect their productivity, because a high-slump mix, free of cement lumps could cost too much and delay other deliveries of concrete. First, the batching computers will have to be altered at the time of batching, and this alone takes valuable time. Second, plant personnel must be further trained on multiple batching guidelines not in use today. Third, the delicacy and precision that must be used to batch a high-slump concrete (due to water additions and mixing revolutions) takes too much time and effort on their part.

\subsection{CURRENT SPECIFICATIONS}

The American Society for Testing of Materials (ASTM), the Florida Department of Transportation (FDOT), the American Concrete Institute (ACI) and the National Ready Mix Concrete Association (NRMCA) provide guidelines for mixing and batching normal slump concrete. The ACI 211 and ACI 318 provide codes and "commentary 
regarding the quality, mixing, and placing of concrete" (ACI, 1999). In publication C 94 called "Standards Specifications for Ready Mix Concrete" ASTM provides specifications that cover "ready-mix concrete manufactured and delivered to a purchaser in a freshly mixed unhardened state as hereinafter specified" (ASTM, 2001). This code refers to the ordering, purchasing, materials, slump tolerances, air-entrained, measuring materials, batching plant, mixers, mixing, delivering, batch ticket, plant inspections, test methods, strength, and the uniformity requirements of concrete. In Florida, a more regional code is used by the FDOT. FDOT section 346-6.2 is an example of additional concrete mix design specifications used in Florida. Its purpose is to "furnish concrete in accordance with specified requirements, or order concrete from an FDOT approved plant that has approved mix designs" (FDOT, 2001).

\subsection{HIGH-SLUMP CONCRETE}

The ease of placing, consolidating, and finishing freshly mixed concrete is called workability. Concrete should be workable but should not segregate or bleed excessively. Because of the tendency of freshly mixed concrete to segregate and bleed, it is important to transport and place each load as close as possible to its final destination. Entrained air improves workability and reduces the tendency of freshly mixed concrete to segregate and bleed (FDOT, 2001).

The engineer specifies the workability of concrete, in order to meet the requirements of the construction. Depending on the function or accessibility of the 
member being cast, a workability or slump measurement is specified. The concrete batch is measured using a "slump test" in order to verify the correct workability of the concrete at the time of casting (Appendix A.6). A slump of 2 to 4 inches is normally used in most construction sites, while high slump concrete ranges from 7 to 8 inches (Markert, 2001). High slump concrete is used in drilled shafts (Figure 1.3) because casting requires a more fluid or workable concrete. The additional water provides the concrete the extra mobility to maneuver through the steel reinforcement and soil around it.
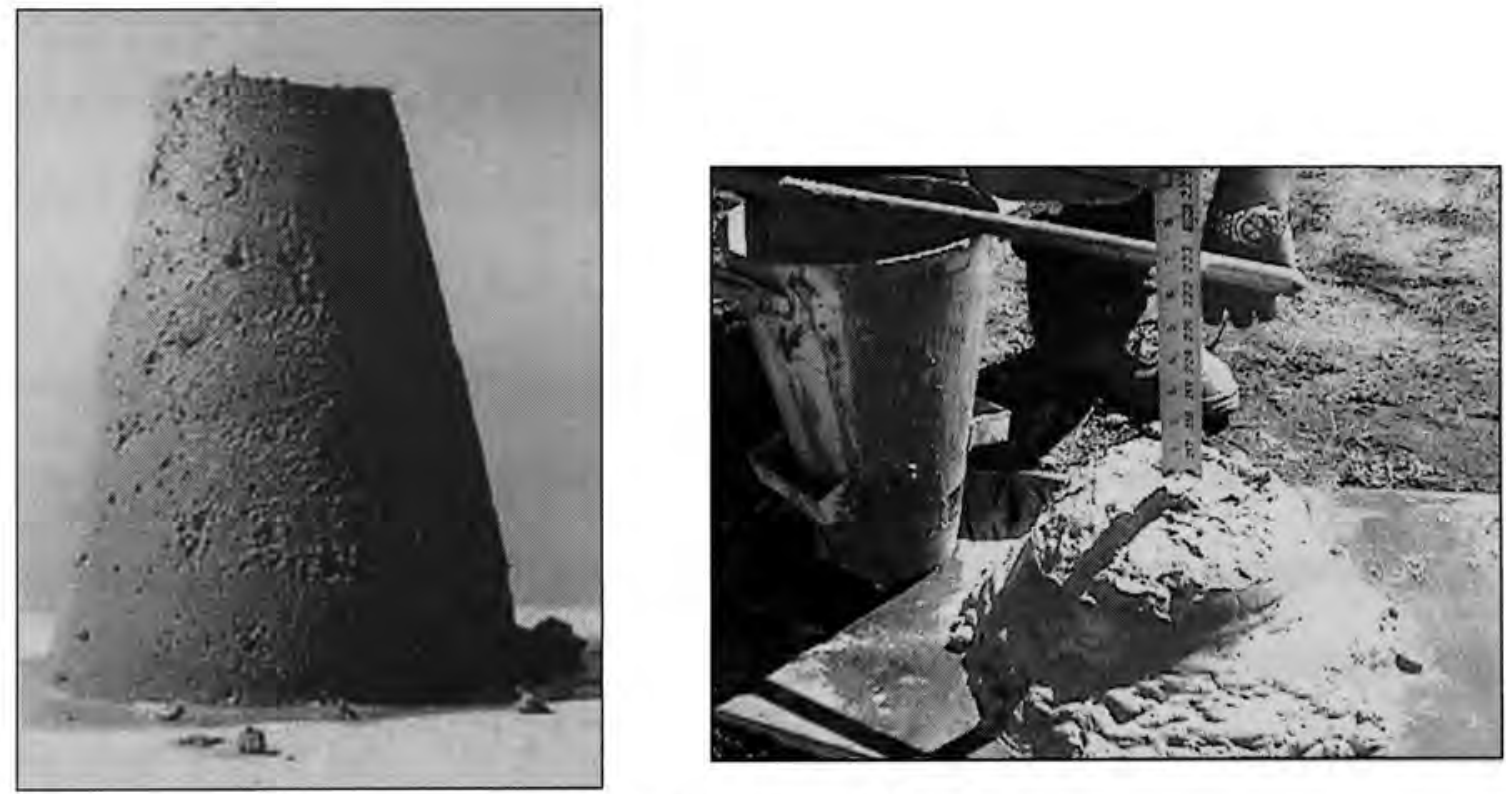

Figure 2.1 Slump of Concrete 


\subsubsection{Code Specifications}

The Florida Department of Transportation codes include section 346-3.2 (FDOT, 2001) for drilled shaft concrete or high-slump concrete. This section briefly explains specifications, slump test procedures, and how to use high-slump concrete, but gives no indication of how to properly mix it. When drilled shaft concrete is specified or required in the contract documents and is to be placed in any wet shaft, it is required to provide concrete in accordance with the specified slump loss requirements.

When concrete is placed in a dry excavation, it is expected to test for slump loss, except where a temporary removable casing is required (FDOT, 2001). The drilled shaft concrete has a slump between 7 inches and 9 inches when placed and maintains a slump of 4 inches or more throughout the drilled shaft concrete elapsed time. It must be ensured that the slump loss is gradual as evidenced by slump loss tests. The concrete elapsed time is the sum of the mixing and transit time, the placement time and the time required for removal of any temporary casing that causes or could cause the concrete to flow into the space previously occupied by the temporary casing. The slump loss tests are performed before drilled shaft concrete operations begin and before they cease, demonstrating that the drilled shaft concrete maintains a slump of at least four inches throughout the concrete elapsed time. The Engineer should be informed at least 48 hours prior to performing such tests in order to allow arrangements to be made for a FDOT representative to witness the mixing and testing required. 


\subsection{PROPORTIONING OF CONCRETE}

The components of a concrete mix are proportioned in order to achieve adequate strength, proper workability, and low cost. Cement, is the most expensive material in concrete. Therefore, the least amount of cement required to attain a satisfactory concrete mix is used. To reduce cost, high-slump concrete batched by Rinker is proportioned with almost equal amounts of blast furnace slag and cement. The aggregates should be well gradated, in order to reduce the volume of cement paste needed to fill the voids between the materials; also, "the coarse aggregate of high-slump concrete should not exceed a nominal size of $3 / 4$ inch" (Kostmatka, Panarese, 1994). By adding water, the plasticity and fluidity of the mix increases, giving the concrete more workability. But, the large volume of voids created by the water, adversely affects the concrete strength. Therefore, the water and cement must be carefully proportioned to maintain both workability and strength. Due to this problem, the high-slump concrete mixed should be proportioned with sufficient amounts of both cement (and slag) and water. As for the cement paste, the water-cement ratio is the decisive influence or prime factor that controls the strength of the concrete.

Although concrete is composed principally of coarse and fine aggregates, portland or hydraulic cement, and water; most mixes today include additional cementitious materials and admixtures. Air-entraining admixtures improve freeze-thaw resistance and other qualities. Chemical admixtures are often used to accelerate or retard set, improve workability, reduce mixing water, and/or increase strength. Natural pozzolans, fly ash, 
and slag's supplement or replace a portion of the portland cement and alter concrete properties (Rose, 1991). An air-entrained admixture, water retardant admixture, a water reducer admixture and fly ash slag are all used in this research as part of the high-slump concrete design in this research (Table 3.1). Using these materials, designers can tailor and adjust mixes to meet a wide variety of performance requirements. But following this procedure requires an understanding of the basic mix design approach (Appendix D, ACI 211).

Inevitably, strength properties of a concrete mix of given proportions vary from batch to batch. It is therefore necessary to select proportions that will furnish an average strength sufficiently greater than the specified design strength for even the accidentally weaker batches to be of adequate quality.

Proportions are controlled, by weight, by means of manually operated or automatic dial scales connected to the hoppers. The mixing water is batched either by measuring tanks or by water meters. Batch quantities are often defined in terms of the total weight of each component needed to make up 1 cubic yard of wet concrete; such as $517 \mathrm{lb}$ of cement (and slag), $300 \mathrm{lb}$ of water, $1270 \mathrm{lb}$ of dry sand, and $1940 \mathrm{lb}$ of dry coarse aggregate. This method is used in this research, and a mix design of this nature is shown in table 3.1 .

ACI 211 (1999) presents the trial-batch method. This method of proportioning is used to obtain mixes of the desired properties from the cements and aggregates at hand. 
Selecting a water-cement ratio from predetermined information on a table, in connection with a set of tables that for a variety of conditions (types of structures, dimensions of members, degree of exposure to weathering, etc.), produce several small trial batches with varying amounts of aggregate to obtain the required strength, consistency, and other properties with a minimum amount of paste (ACI 211, 1999).

Mix design weights must be adjusted for variable moisture contents of the aggregates at the time the aggregates are batched. The adjusted weights are termed batch weights. For example, if the aggregate contains free moisture in excess of that required to fill aggregate pores, the free moisture is part of the mixing water (Rose, 1991). Because some of the as-batched weight of aggregate is water, adjusted aggregate batch weights must be greater than design weights. Water added through a water meter or weigh batcher must be reduced by the amount of free water present on the aggregate. The engineer must also consider the job site water allowable to be used as a slump water addition in the high-slump mix design. The water additions are further explained in Chapter 3.

\subsection{CONCRETE MIX DESIGN}

There are a number of accepted concrete design methods for ready mix concrete. The American Concrete Institute (ACI), founded in 1905, is a non-profit organization dedicated to public service and to representing user interest in the field of concrete. ACI provides an extensive concrete quality, mixing, and placing code and commentary in Chapter 5 of the Building Code and Commentary 318 (ACI, 1999). It defines and 
explains the current ready mix concrete code specifications, by "describing procedures that concrete of adequate strength can be obtained and providing procedures for checking the quality of concrete during and after its placement in the work" (ACI, 1999).

The goal of any mix design process is to produce a concrete that will meet performance requirements for the specified conditions and use (Rose, 1991). Performance is usually related to strength, durability, and appearance of the hardened concrete. But the combination of materials used must also be a practical one, producing a mix that is workable and economical. In most mix design procedures, quantities of materials are determined for a unit volume, usually a cubic yard or cubic meter of concrete. Weights of water and cementitious materials are first chosen, since these have primary effects on workability, strength, durability, and economy. Volume of entrapped or entrained air is estimated. The optimum ratio and weights of coarse and fine aggregates are then calculated to achieve adequate workability and to provide the bulk material to fill the unit volume. Solid volumes of each component are calculated using the specified weights and specific gravities of each component.

ACI 211 or "Standard Practice for Selecting Proportions for Normal, Heavyweight, and Mass Concrete" (ACI, 1999) is the most widely used guide for concrete mix design. The method has a sound technical basis and provides a first approximation of proportions. But as with any other method, calculated proportions are subject to revision on the basis of experience with trial batches. A list of outlined mix design steps is shown in Appendix D. 
A more regional code is also available from the Florida Department of Transportation, called "Portland Cement Concrete" or FDOT section 346.6 (FDOT, 2001). It is available for mix design requirements and procedures for Portland cement concrete. Its purpose is to provide concrete in accordance with FDOT requirements or order the concrete from a plant approved by the department that has approved mix designs. For detailed information of the proposed mix design submittal requirements see FDOT 346-6 in Appendix B.

FDOT requires the engineer to have the highest water-cement ratio demonstrated, to provide the required over-design strength requirements as an adjustment during production to maintain both plastic property and strength requirements of delivered concrete. The standard deviation must represent either a group of at least 30 consecutive tests or a statistical average for two groups totaling 30 or more tests. If the engineer cannot determine the plant standard deviation from historical data, code allows an overdesign requirement (FDOT, 2001).

The 28-day strength of trial mixes should meet the over-design requirements of section $346-6$, to ensure that concrete sampled and tested at the point of placement has a strength exceeding the specified minimum strength of 3,400 psi for Type II cement as shown in table 2 in of FDOT 346 in Appendix B. For design mixes proposed for use in wet drill shafts, additional requirements of FDOT 346-3.2 must be demonstrated (Appendix B). (For details on establishing the standard deviation of a plant please see FDOT 346.) 


\subsection{TRUCK MIXER}

The truck mixer used in this research is a ten cubic yard; rear loaded mixing truck, normally loaded with nine cubic yards of concrete (Figure 2.2). The truck has three internal blades (Figure 2.6), and both the blades and truck must be in perfect working conditions. The truck is NRMA, TMMB and FDOT certified. (For more details on the truck used in this research, please see Section 3.4).

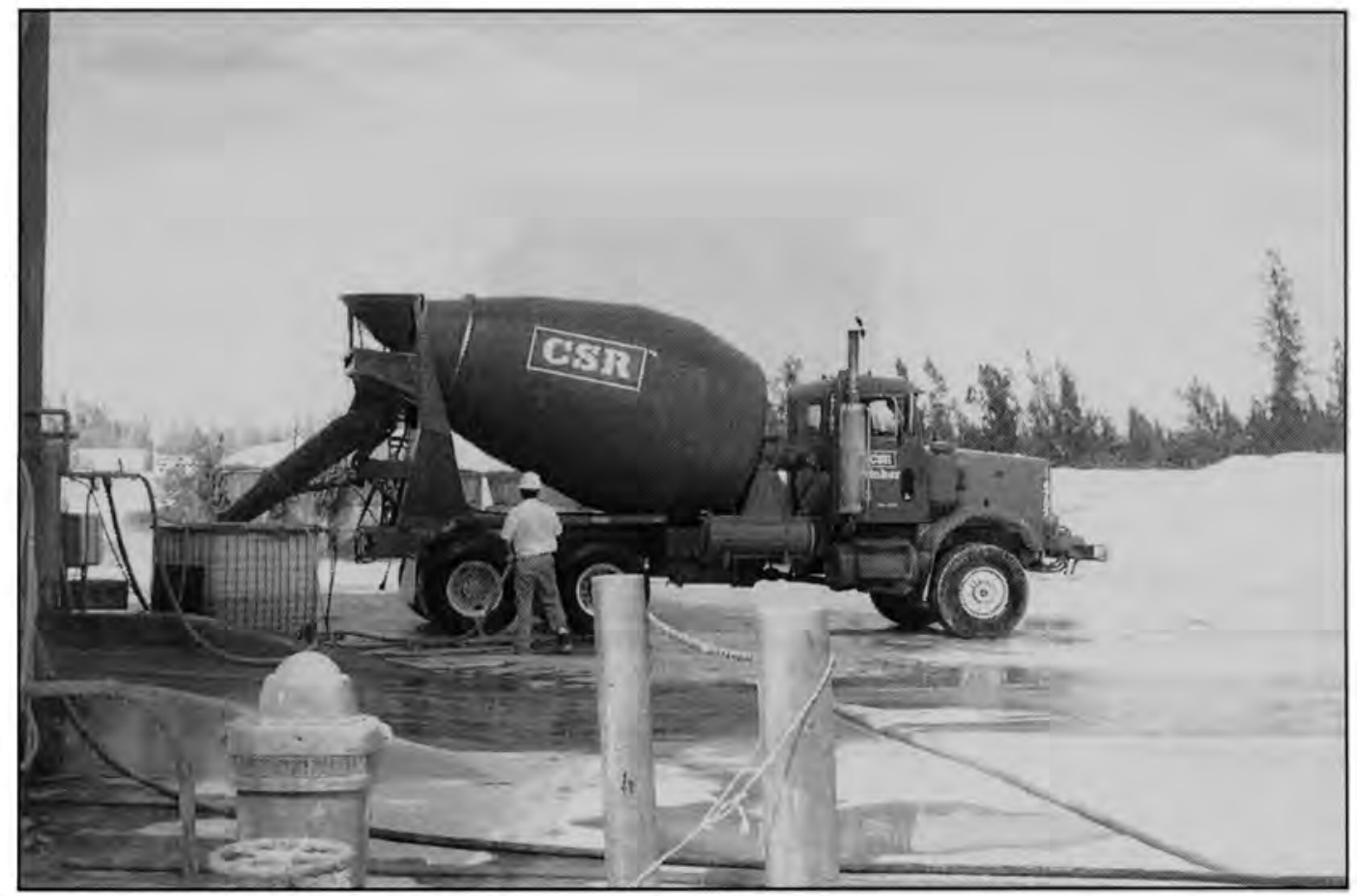

Figure 2.2 CSR Rinker Truck Mixer 
To ensure high-quality ready mix concrete a number of organizations standardize procedures and create code. One of these organizations is called, the Truck Mixer Manufacturers Bureau (TMMB). TMMB is affiliated with the National Ready Mix Concrete Association (NRMCA). Together, these organizations establish standards for truck mixers and agitators. These standards establish requirements for:

- Volume limitations

- Water tank and water system options

- Water measuring devices

- Water injection

- Inspection hatches

- Mixing speed

- Agitator speed

- Rated mixing capacity

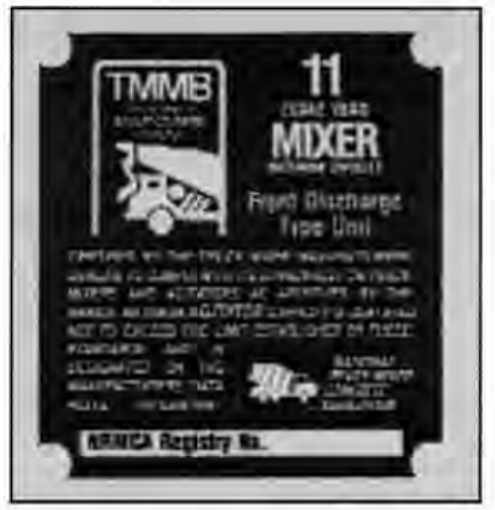

Figure 2.3 TMMB Rating Plate

Contractors must be sure that concrete is mixed and delivered in a truck meeting TMMB standards, by looking for the TMMB rating plate on the truck (Figure 2.3). 
Other codes available come from the American Standards for Testing of Materials and the Florida Department of Transportation. ASTM supplies truck mixer requirements and procedures in section 10 of their C 94 code (ASTM, 2001). Similar to the TMMB, ASTM and FDOT require each truck mixer or agitator to have attached a metal plate or plates on which identify the following (Figure $2.3 \& 2.4$ ):

1) the gross volume of the drum

2) the capacity of the drum or container in terms of the volume of mixed concrete,

3) the minimum and maximum mixing speeds of rotation of the drum, blades, or paddles.

When the concrete is truck-mixed as described in ASTM C 94 (Section 11.5) and FDOT 346, the volume of mixed concrete cannot exceed $63 \%$ of the total volume of the drum or container. Truck mixers must be equipped with counters to readily verify the number of revolutions of the drum, blades, or paddles. The truck mixer must be capable of combining the ingredients of the concrete within the specified time or the number of revolutions specified. Uniformity requirements: like using longer mixing time, smaller loads, or a more efficient charging sequence can be stipulated by the engineer. This will be the case in this project, because the test batches conducted will vary all of the previous cases. The mixer must maintain the mixed concrete in a thoroughly mixed and uniform mass and discharging the concrete with a satisfactory degree of uniformity (ASTM C 9410 or FDOT 346 in Appendix B). 


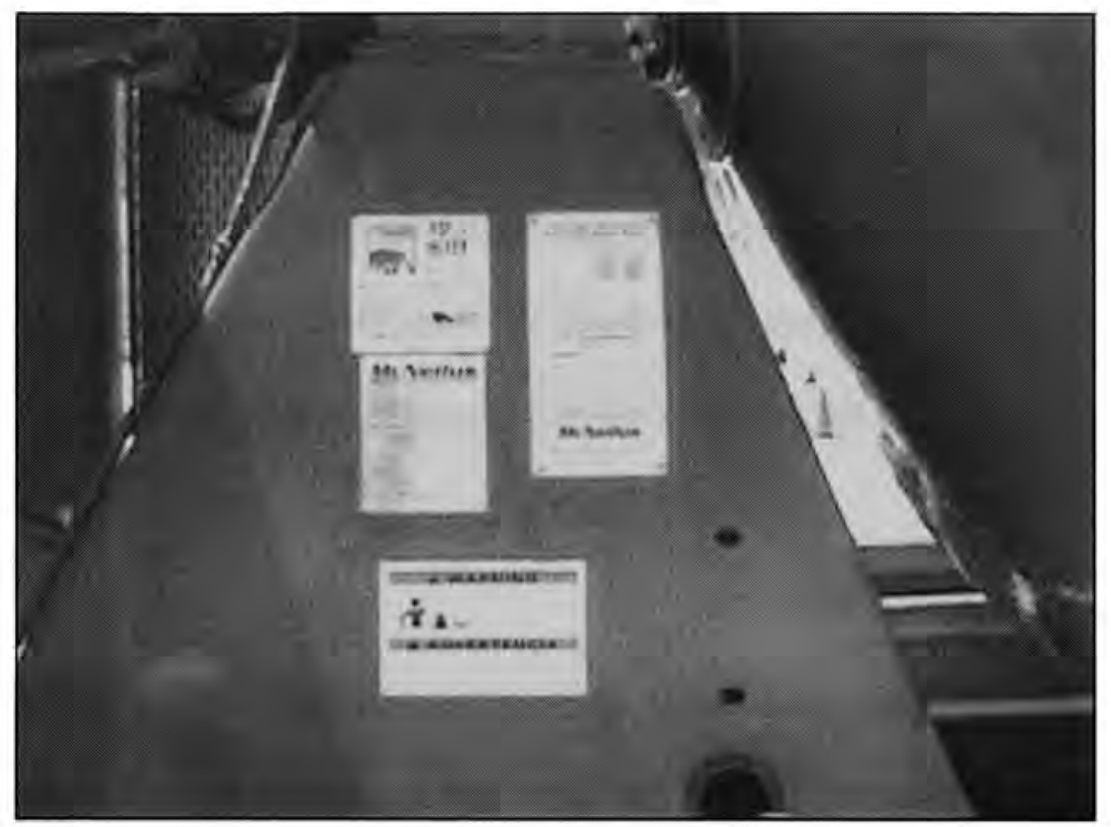

Figure 2.4 Required Capacities and Approval Metal Plate of a CSR Rinker Truck mixer

Similarly, ASTM and FDOT require the truck mixer to be capable of discharging the concrete with a satisfactory degree of uniformity; free from balls or lumps of cementitious material (FDOT, 1999). This is the reason this research is being performed. (Note: The sequence or method of charging the mixer will have an important effect on the uniformity of the concrete. For additional information please refer to Section 2.7).

ASTM C 94 recommends that slump tests (Section 2.2 and Appendix A) of individual samples be taken after discharge is approximately at $15 \%$ and at $85 \%$ of the load, in order to provide a quick check of the probable degree of uniformity. These two 
samples shall be obtained within an elapsed time of not more than $15 \mathrm{~min}$. A sample at the middle of the load can be a pretty good measure of the uniformity and therefore the sample will taken at that time in this research batching procedures. No samples should be taken before $10 \%$ or after $90 \%$ of the batch has been discharged. Due to the difficulty of determining the actual quantity of concrete discharged, the intent is to provide samples that are representative of widely separated portions, but not the beginning and end of the load.

The Florida Department of Transportation uses truck mixers of the inclined axis revolving drum type. The batching plant must make available at all times a copy of the manufacturer's design, showing dimensions and arrangement of blades (Figures 2.5 and 2.6). Truck mixers must be equipped with a hatch in the periphery of the drum shell which permits access to the inside of the drum for inspection, cleaning and repair of the blades. The water supply system mounted on truck mixers must be equipped with a volumetric water gauge or approved water meter in operating condition. When job site water additions are controlled by a truck mixer volumetric gauge, if the additional water exceeds $4 \mathrm{gal} / \mathrm{yd}^{3}$ of concrete, ensure that the water measuring equipment has an accuracy of within $3 \%$ of the indicated quantity. (Note: These water additions will create the highslump concrete in this project, Sections 3.4). 


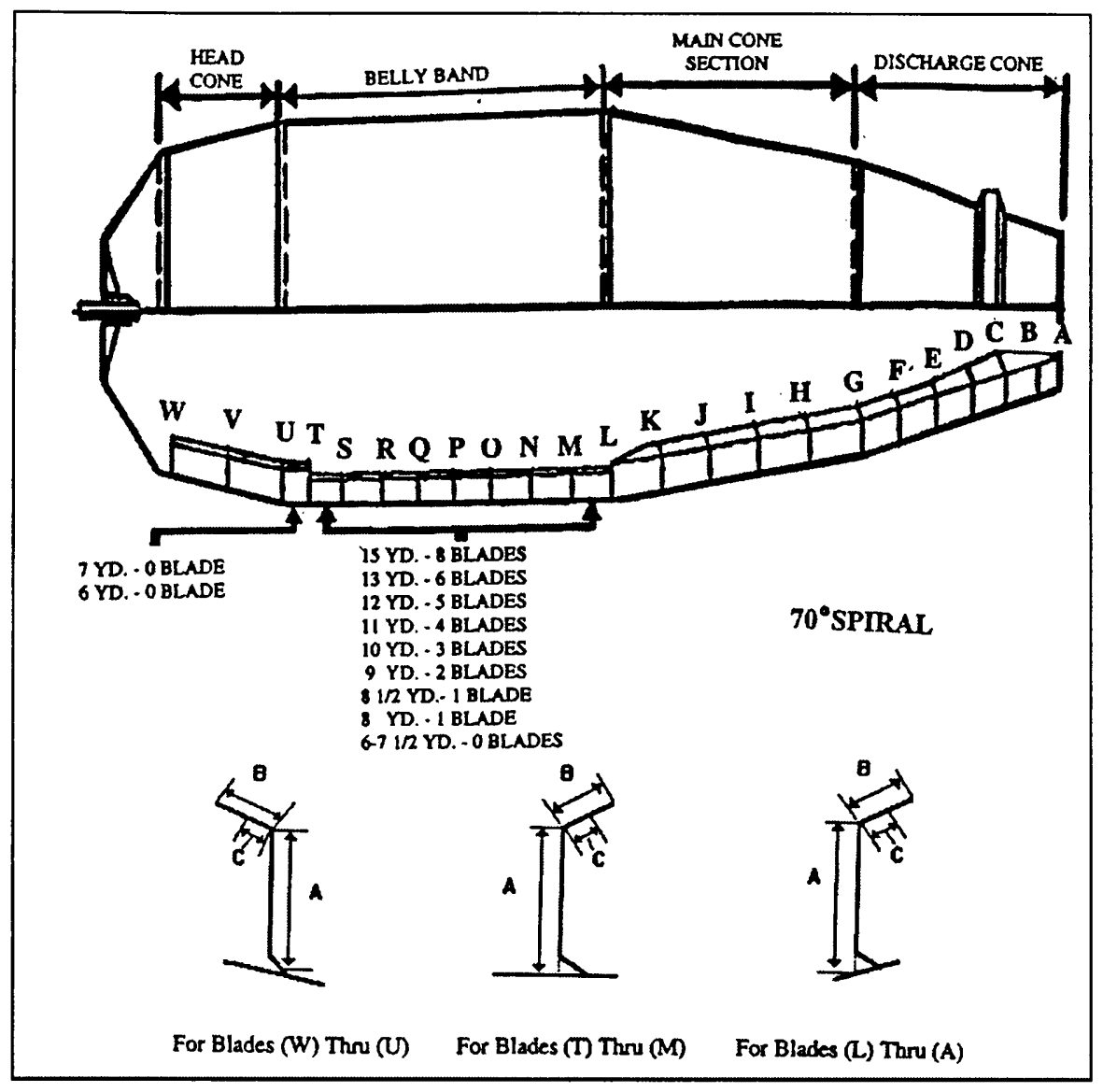

Figure 2.5 Truck Mixing Drum Layout (FDOT)

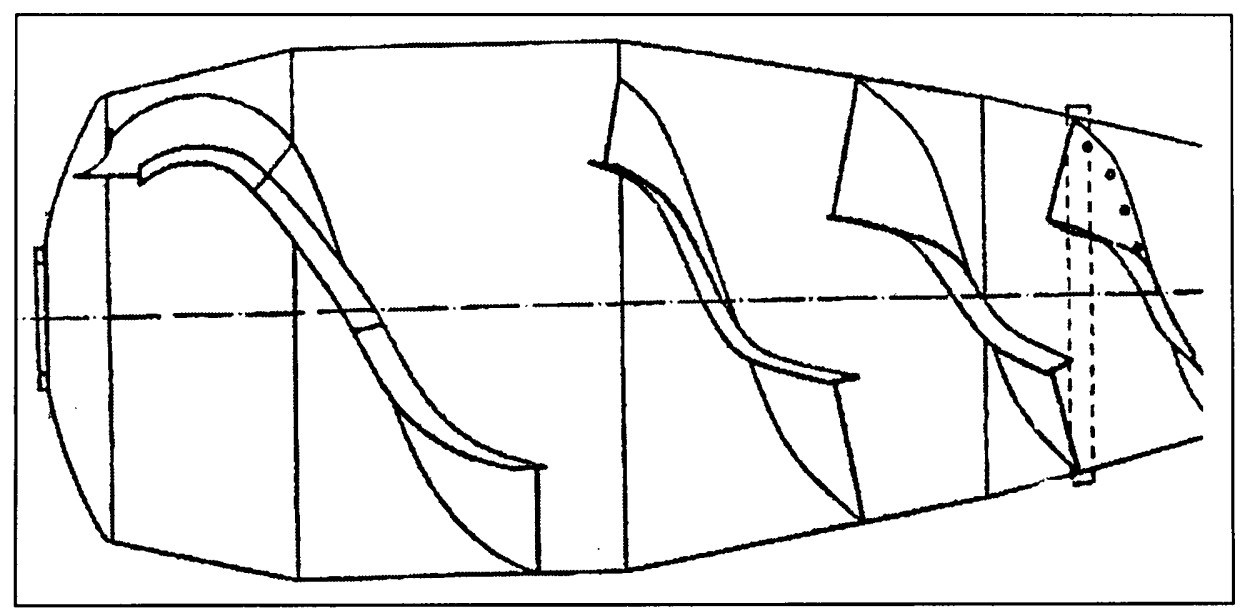

Figure 2.6 Drum Blades (FDOT) 
Finally, FDOT suggest repairing or replacing the mixer blades of revolving drum type mixers when the radial height of the blade at the point of maximum drum diameter is less than $90 \%$ of the design radial height. One may resolve questions of performance through mixer uniformity tests as described in ASTM C 94.

\subsection{CONCRETE MIXING}

Ensuring that the components of concrete are combined into a homogeneous mix requires effort and care. The sequence of charging ingredients into the mixer plays an important part in the uniformity of the finished product. The sequence, however, can be varied and still produce a quality concrete. Different sequences require adjustments in the time of water addition, the total number of revolutions of the mixer drum, and the speed of revolution. Adjustments in the time of water additions and the total number of revolutions were performed to mix the high-slump concrete used in this research. Other important factors in mixing are the size of the batch in relation to the size of the mixer drum, the elapsed time between batching and mixing, and the design, configuration, and condition of the mixer drum and blades. All of which are studied in this research in highslump concrete. "Approved mixers, correctly operated and maintained ensure an end-toend exchange of materials by a rolling, folding, and kneading action of the batch over itself as the concrete is mixed" (CPCA, 2001). 


\subsubsection{Mixing Codes}

The FDOT 346 (Appendix C) and the ASTM C (2001) requires truck mixers to have mixing speeds of 6 to $18 \mathrm{rpm}$ and agitating speeds of 2 to $6 \mathrm{rpm}$ (Agitating speed used when charging the materials into the drum) when mixing concrete. The volume of material mixed per batch must not exceed the manufacturer's rated mixing capacity (Section 2.5). The initial mixing time of each batch is between 70 and 100 revolutions of the drum at mixing speed (12 to $18 \mathrm{rpm}$ ). When water is added at the job site (job site allowable) the concrete must be mixed for an additional 30 mixing revolutions. If one is mixing for the purpose of adjusting consistency, one cannot allow the total number of revolutions at mixing speed to exceed 160 . All the concrete must be discharge from the truck mixer before total drum revolutions exceed 300 (mixing and charging). Each batch is charged into the drum so that some water enters both, in advance of and after the cementitious material and aggregates (loading procedures, Section 2.8.3). If the batch requires the use of fly ash in the mix, charge it into the drum over approximately the same interval as the cement. For more detailed information please refer to Appendix B.

\subsection{PRODUCTION MIXING TECHNIQUES FOR TRUCK MIXED CONCRETE}

In a truck mixed concrete, all raw ingredients are charged directly into the truck mixer drum. Most or all water is usually batched at the plant. The mixer drum is turned at charging (4 rpm) speed during the loading of the materials. According to the National 
Ready Concrete Mix Association (NRMA) there are three production techniques for truck mixed concrete:

1) Concrete mixed at the job site: While traveling to the job site the drum is turned at agitating speed (slow speed). After arriving at the job site, the concrete is completely mixed. The drum is then turned for 70 to 100 revolutions, or about five minutes, at mixing speed to ensure uniform mixing.

2) Concrete mixed in the yard: The drum is turned at high speed or $12-15 \mathrm{rpm}$ for 50 revolutions. This allows a quick mixing of the batch. The concrete is then agitated slowly while driving to the job site.

3) Concrete mixed in transit: The drum is turned at medium speed or about $8 \mathrm{rpm}$ for 70 revolutions while driving to the job site. The drum is then slowed to agitating speed till it reached the job site.

\subsection{PRIOR RESEARCH}

By now, one can see the limited information available by the way of research or codes for high-slump concrete. The attempt of chapter two is to use current concrete technology (i.e., normal-slump concrete) as a basis and apply it to high-slump concrete. Most of the topics discussed in this chapter are relevant to both normal and high-slump concrete. The following are previous concrete homogeneity research performed in normal 
slump concrete. Still, they illustrate procedures that can be incorporated and used or enhanced in order to mix high-slump concrete.

\subsubsection{Mixing Concrete in a Truck Mixer}

The National Ready Mix Concrete Association has extensively researched the mixing sequence used to batch concrete in a truck mixer. Batching procedures create the biggest homogeneity problems if not properly conducted. Former director of the NRMA Mr. Richard Gaynor provides an elaborate research for mixing concrete in a truck mixer. Gaynor and his team conducted elaborate testing for a period of three years from 1969 to 1972. Publication No. 148 called "Mixing Concrete in a Truck Mixer" (NRMCA, 1975) investigated the factors that determine the homogeneity of concrete (Gaynor, 1975). The study points out that the loading sequence greatly influences the homogeneity of the mix. The study is a collection of batching results, in which the sequence of loading the materials in a truck mixer is extensively tested. From these tests an optimum loading sequence is attained.

Gaynor outlines "factors that determined the homogeneity of concrete as it comes from the truck mixer" (Gaynor, 1975). These factors are summarized in these thirteen conclusions and recommendations:

1. Method of loading. Cement last, slurry mix, and ribbon are examples of different loading methods. This is the most influential variant and it has the greatest effect 
on the batch uniformity. If not properly mixed the method of loading should be examined first. Furthermore, the water adding procedure should also be examined.

2. Blending Fine and Coarse Aggregate. When coarse aggregates are batched as two separate sizes and the maximum size is greater then one and one-half inches (1.5"), the fine and coarse aggregates should be blended during charging. In all loadings, the coarse aggregate should start ahead of the sand in order to avoid head packs. Non-uniform distribution is more likely to occur on high slump concrete due to segregation during discharge rather than improper mixing.

3. Ribbon Loading. These loadings involve blending of sand, gravel, and cement during the loading cycle. Ribbon loading is susceptible to the formation of headpacks and cement balls. In order to avoid this, the coarse aggregates and some water should be placed before the sand and cement. The charging of water is reasonably flexible in this loading. The best uniformity was obtained when half of the water was batched before the solids and half after the solids.

4. Cement-Last Loading. This type of loading is very sensitive to the method of adding water and can be either very good or very poor in uniformity. The advantage of this loading is that if the cement is loaded last without turning the drum and mixing is performed after arrival at the job, then very little cement becomes wetted and delivery time can be extended an hour or more without loss in quality. These are useful when a plant needs to handle a variety of different cements and aggregates. The maximum batch size will be less than rated mixer 
capacity. Coarse aggregate should lead the sand and cement to avoid head-packs and $1 / 4$ of the water should be added after the cement.

5. Sandwich Loadings. This loading involved charging the cement between equal increments of ribboned aggregates and water. Mixing was marginally acceptable.

6. Double Batching. Two, four cubic yards cement-last batches were used. Although mixing was only marginally acceptable, uniformity was much better than a single eight cubic yard drop of this same loading.

7. Slurry Mixing. The time required for this procedure makes it impractical, but it produced the best uniformity and strength. Furthermore, it avoided the occurrence of head-packs, sand streaks and cement balls. This is a good loading to try when nothing else works.

8. Mixing Revolutions. When concrete is improperly mixed, additional revolutions will not necessarily solve the problem. A change in loading procedure is likely to provide the best solution. In loadings where mixing is marginal to fair at 50 revolutions the additional mixing of 100 or 150 revolutions will produce only modest improvement. Only rarely will an increase from the ASTM minimum of 70 to the maximum of 100 produce a marked improvement in uniformity. As a general rule the number of revolutions should be doubled to obtain significant improvement in uniformity.

9. Mixing Speeds. These tests demonstrate that in the range of 4 to $12 \mathrm{rpm}$, drum speed does not significantly affect the uniformity obtained in a fixed number of revolutions. However, mixing does improve in the range of 12 to $22 \mathrm{rpm}$ 's in some cases. Above $22 \mathrm{rpm}$ mixing deteriorates. 
10. Tempering Water. When the quantity of water added is less than 2.5 gallons per cubic yard, there was no measurable difference whether the water was added through the nozzle in the hub or the one in the discharge end of the drum.

11. Charging Speed and Inclination. This does not greatly influence mixing, headpacks, or cement balls.

12. Batch Size. This is not one of the critical variables affecting uniformity. A one or two cubic yard reduction of the rated mixer capacity will produce a modest improvement in uniformity, but seldom will such a change solve serious uniformity problems.

13. Concrete Proportions and Materials. Limited test were conducted with concrete of different slumps, air contents and cement contents using a variety of aggregates. These variations in the mix composition did not have large or constant effects on the ease or difficulty of producing well-mixed concrete.

\subsubsection{Avoiding Uniformity Problems in Truck-Mixed Concrete}

Mr. Richard Gaynor outlines the problem of cement balls in an essay published in concrete world by the Aberdeen group called, "Avoiding uniformity problems in truckmixed concrete" (Gaynor, 1996). Although he mainly refers to normal slump concrete, 2 to 3 inches, he briefly mentions the problem in high-slump concrete. Gaynor talks about solutions to resolve the problem. First, he proposes to avoid cement balls by changing to slurry mixing. Gaynor suggests loading all the water, then the cement and mix for one 
minute at a high drum speed. Finally, the fine and coarse aggregate are ribboned in. The slurry mixing method works, but the procedure has proved to be time consuming and messy. Next, Gaynor recommends a more practical solution to the problem, by optimizing the loading procedure of coarse aggregate and water.

Gaynor states: "Put about 4,000 pounds of coarse aggregate into the drum first to avoid a head pack. Then add about $3 / 4$ of the water, ribbon in the rest of the aggregate (coarse and fine) and cement (Figure 2.7). And finally add the remaining $1 / 4$ of the water" (Gaynor, 1996). He mentions that the most important part is the $1 / 4$ of the water as the last ingredient. If more is used, nonuniform batching will occur. Moreover, Mr. Gaynor believes "a wet spots form in the discharge end of the drum before concrete in the head of the drum has any measurable slump. This prevents the needed flow pattern from developing" (Gaynor, 1996). Gaynor writes that

\section{To avold cement balls}

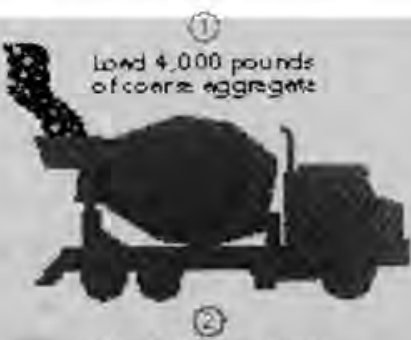

Add $3 / 4$ of the water

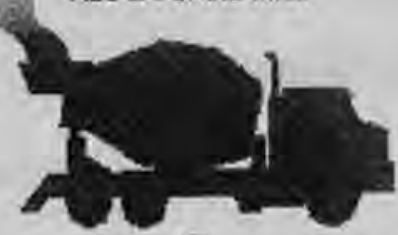

(3)

Ribbon bond cement, and. and rest of cos res nggregnte

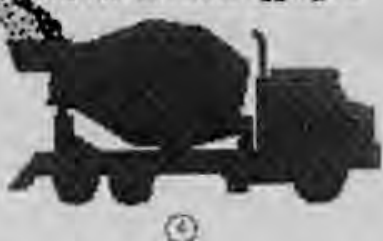

Add $h=1 / 4$ of weter

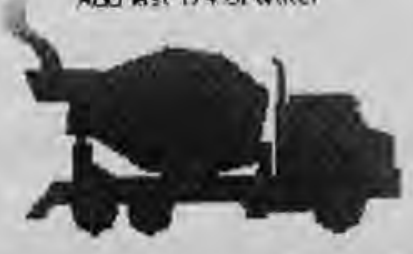

Figure 2.7 Batching Procedure

(Gaynor, 1996) 
head-packs are a result of sand being loaded before the coarse aggregate and before and accumulating in the front of the drum. Gaynor believes: "despite the absence of visual clues, head packs are undesirable because they cause variations in slump, air content, and strength (Gaynor, 1996). The flow pattern in the drum is also important. In order to see if one has the desired flow pattern; one must look inside the drum. Last, Gaynor refers to the wear of the mixing blades briefly mentioned in Section 2.5. He states: "vertical height of the blades should not be worn down by more than $10 \%$ of the original height" (Gaynor, 1996).

The non-uniformity of truck mixed concrete causes the development of head packs and concrete balls. Head packs refer to sand streaks that appear when discharging the final portions of the concrete. Head packs are produced when sand is loaded before coarse aggregates. The sand packs in the head of the drum and breaks loose after about half the load has been discharged. Usually the head pack goes unnoticed because the sand gets mixed into the concrete before it reaches the chute. Head packs can be avoided by loading sand and cement together after $50-75 \%$ of the coarse aggregates and water has been charged in the truck (Gaynor, 1996).

In the previous methods, Gaynor is referring to normal slump concrete. Although helpful in providing a guide to mix high-slump concrete, the procedures described by Gaynor do not recognize the difference in water of both concretes. He briefly mentions high-slump concrete and states a short term solution: 
"One quick way to fix this is to mix the concrete at a 2 inch slump, then add enough water to reach the desired slump. However, this is an ineffective solution because cement balls are a cause of improper loading or batching sequences. But, this procedure creates other problems such as shrinkage and high creep; furthermore, this is an expensive and timely solution" (Gaynor, 1996).

Gaynor discourages the practice of batching a 2 or 3 inch concrete and then using the job site allowable water to increase the slump to 8 inches. Nevertheless, to achieve the high amount of water needed in high-slump concrete, this method is the most commonly practiced and is used by CSR Rinker. However, this practice produces many cement lumps in the high-slump mix used by FDOT for drilled-shaft concrete. Therefore, this research must optimize this two part process batching procedure. Gaynor tells us that cement lumps are a cause of improper loading and sequence procedures; hence by finding the critical sequence and rates of the concrete materials; and water prior to any slump water adjustment, this research can theoretically provide an improved batching procedure for the drilled-shaft concrete mix used in this research. If initially, the concrete is not properly mixed, then any addition of water will increase the problem. In other words, the concrete must be well mixed in advance to any slump water adjustments. 


\subsubsection{CSR Rinker loading Sequence}

Because the loading sequence has been sufficiently tested and industry professionals such as CSR Rinker accept it as a standard, the loading sequence will not be studied in this research. The loading sequence to be used in the loading procedure in attachment \#11 of Sweetwater, No. 87-274 or the "Drill Shaft Concrete Loading Sequence" for FDOT Concrete (Appendix F).

1) Batch will be initiated with the charging of $50 \%$ to $90 \%$ of the batch water with all the admixtures.

2) Aggregates will begin charging.

3) After initiation of aggregate charge, cementitious material will be "ribbon fed" into the aggregate stream. Discharge of cementitious material will be completed prior to the completion of the aggregate charge.

4) Truck mixer will move out from under the concrete plant and begin initial mixing of the concrete.

5) Once the initial mixing is completed, the truck mixer will move back under the concrete plant and the balance of the batch water will then be added, via plant water meter, to the mixer.

(Note: Step 5 was changed to:

Truck will drive to slump stand where job site allowable water will be introduced. Both headwater and tail water are charged by the plant. (Please refer to Chapter 3). 


\subsection{PROFESSIONAL OPINIONS}

A lack of books and journals of reliable information on batching high-slump concrete required this author to send questioners via e-mail, to government and private concrete engineers inquiring information of their high-slump concrete batching practices. Corresponding with engineers across the nation, many similarities are noticed in techniques for batching high-slump concrete. Next are a few of these techniques and opinions.

\subsubsection{California Department of Transportation}

Mr. Daniel Zuhlke from the California Department of Transportation states his opinion why cement balls are formed: "increased water in a concrete mix tends to ball the cement since the dry cement coats rapidly with the water and leaves the interior dry" (Zuhlke, 2001). In other words, the cement is mixing with the aggregate before water can reach it. Mr. Zuhlke goes on to write on the remedy to the problem.

"To mitigate this condition, add mix water into the mixer over the full period of charging the mixer with the dry material. Ribbon feed the dry material at the same time. The mixer must be clean and in good condition, not overloaded, and operating at optimum speed; also make sure the mixer blades are not worn more than 10\%" (Zuhlke, 2001). 


\subsubsection{Georgia Department of Transportation}

Mr. Robert Crown from the Georgia Department of Transportation writes:

"It is Georgia's experience that lumps are usually related more to the batching sequence of the materials at the plant site. Batching sequence will vary at different plants due to type plant, central mix, dry batch or shrink mix. We have had very few problems with lumping. Most plants charge a portion of the mix water first and then some aggregate before the cement is charged. We have had, in some instances, where the water and cement stick in the front of the drum (head pack) and comes loose during transit and we end up with $0 "$ slump at the job and not enough water to bring it back to a usable slump. Changing the batch sequence solved the problem. Therefore, since there are varying batching situations, we depend on each producer to know his best batching sequence instead of specifying" (Crown, 2001).

\subsubsection{Online Concrete Database}

Using an online concrete database called Dr. Concrete, Mr. Kenneth from Austin, TX. States: "I don't know of any studies, but I can tell you from experience what can cause lumps or balls in the mix, whether it is high or low slump: There are several factors that contribute to those unsightly concrete balls coming out of your mixer and irritating the finishers. Worn down fins or fins with build up; charging speeds too slow or too fast; putting water in with cement; putting wet sand in with cement; not putting enough head water in the drum; not putting enough coarse aggregate in before adding sand and cement; not mixing long enough before leaving for the job; and the worst cause of all - clay balls in your aggregates. If 
you put as much water and coarse aggregate in the front of the load as you can, that will help overcome some of the other factors that create balls" (Kenneth, 2001).

\subsection{SPECIFIC PROBLEM}

Gaynor concluded that if the concrete is not properly mixed, the method of loading is probably the cause. Moreover, water addition procedure should be examined. This is relevant to our work because of the water additions used to batch high-slump concrete. Any incorrect timing or improper water loading affects the mix. Gaynor believes that ribbon loading is prone to form head-packs and cement lumps. To avoid this, Gaynor, suggests that the coarse aggregate and some water should be placed prior to the sand and cement (Gaynor, 1996). The batch procedure used for this research takes this into account (Section 2.8.3). Finally, Gaynor believes that only rarely will an increase from ASTM minimum of 70 to 100 revolutions produce improvement in uniformity (Gaynor, 1996). The tests batches performed in this reserch will explore the number of revolutions and determine if they improve uniformity for high-slump concrete used by FDOT.

From the professional opinions in the previous section, Zuhlke believes that to mitigate the homogeneity problems one must mix the water over the full period of charging the mix; instead of mixing the water as headwater and tail water. He also cautions to check the condition of the truck and its blades. Crown feels that each batching 
facility has different batching sequences, which are the cause of homogeneity problems. Therefore, it has been his experience to allow the manufacturer to know his best batching sequence. Finally, Mr. Kenneth from Austin, Texas thinks that putting as much water and coarse aggregate in front of the load as possible, one can overcome the factors that create cement lumps.

One may start to perceive cement lumps are most probably a cause of improper loading and sequence procedures, especially in high-slump concrete. High-slump concrete requires an unusually high amount of water in order to meet workability requirements. Batching all materials, including the water directly from the batch machine, does not produce a good mix. This is because the excess water does not permit the mix materials to be thoroughly combined; instead it creates a sea of sporadic materials in the truck mixer. If the concrete does not mix properly, any addition of water will increase the problem and reduce the concrete strength. The purpose of this research is to optimize a batching procedure which is practical and efficient, by optimizing the current high-slump batching procedure used by CSR Rinker. 


\section{CHAPTER 3: METHODOLOGY}

District concrete engineers and district materials engineers from the Florida Department of Transportation, local concrete producer CSR Rinker, as well as Florida State University and Florida International University graduate faculty; conduced experiments in order to determine the extent of the problem and find a possible solution that could remedy the cause of lumps and balls in high-slump concrete. These experiments consisted of concrete tests batches conducted at the CSR Rinker concrete plant in Miami, Florida. A total of seventeen test mixes were batched to gather research information and analyze it in order to narrow the factors or variables with the greatest effect in the high-slump concrete mix homogeneity. Originally, plans called for one phase of testing, but the results of the first set of trial mixes made additional testing necessary to find optimum results. With both phases of the project finalized during April 2001 and March 2002, the tests batches data was ready to be compiled, in order to find the best possible results.

\subsection{TEST VARIABLES}

A number of variables affect a concrete mix. The discharge rate, load size, headwater, tail-water, load sequence, temperature, entrapped air, moisture content of aggregates, aggregate size, mixing time, mixing speed and condition of mixing equipment are a few of the variants that affect a concrete mix. Due to the large scope of 
variants only some of them are studied in this research. Most of the variables not selected to study in depth have been previously researched and are accepted standards by engineering codes. The load sequence, moisture content, aggregate size, entrapped air, temperature, and mixing revolutions are maintained as constants. (Note: The load sequence of a mix has been extensively studied and outlined in section 2.8.3). In addition, from Chapter Two one is able to allocate possible critical values of the mix. The initial variables studied in phase I are: 1) load size, 2) discharge rate, and 3) head-water content of the mix. In phase II the variables are: 1) headwater content and 2) initial mixing revolution. A sufficient number of tests were conducted for each variable under study to provide statistically significant conclusions. Finally, lump samples of the two phases were collected and graded in order to compare the composition of aggregate and cement in the cement balls under study.

\subsection{DESIGN}

The concrete mix design used for this research is the same for all batches. The mix design conforms to ACI, ASTM, and FDOT code specifications as explained in chapter two. The concrete mix is a class IV drill shaft, 4,000-psi concrete and it is a FDOT approved mix numbered \# 06-0281 (Tables 3.1 and 3.2 or Appendix C). 


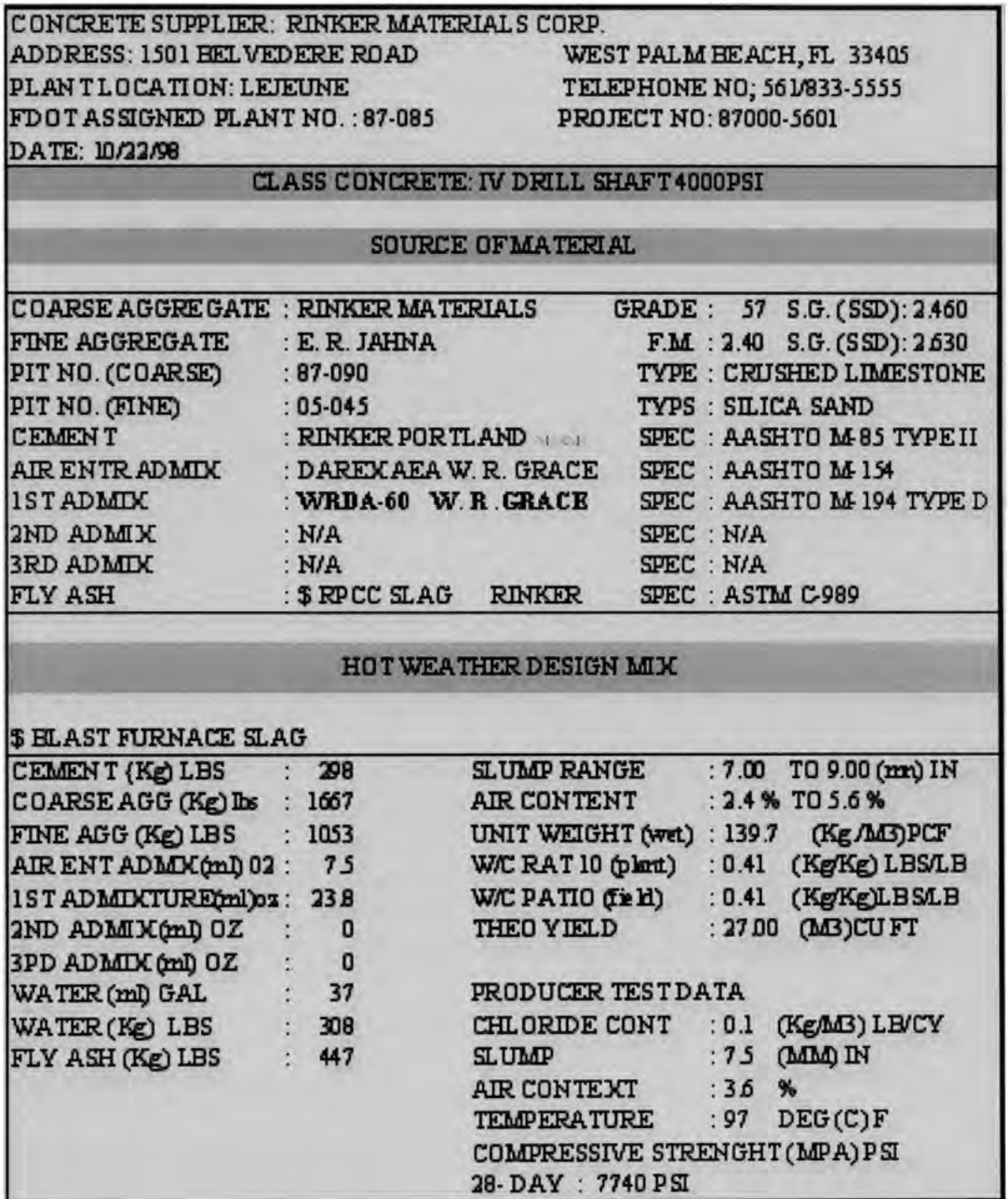

Table 3.1 Mix Design for Phase I 
COHCRETE SUPPLIER: RTHKER MATERIAL S CORP.

ADDRESS: 1501 BEL VEDERE RDAD

WEST PALM BEACH, FL 33405

PLAW T LOCA TION: LEJEUNE

TEJ.FPHONE HO; 56 1/833-5555

FDOT ASSTGKED PLANT KO. : 87-085

PRDJECT HO:87000-5601

DATE: $10 / 2298$

CIASS COHCRETE: IV DRLL SHAFT 4000PSI

SOURCE OFMATERT AL

COARSE AGGREGATE : RINKER MAA TERIALS

FTIE AFGREGATE : E. R. JAHWA

PIT KO.(COARSE) : : 87-090

PIT HO. (FIHE) : :05-045

CEMAEN T

AIR ENTR ADMTX

IS T ADMOXX

2ND ADMIX

3RD ADMTX

FLY ASH
: RINKERR PORTLAHD ।:

: DARETKAEA W. R. GRACE

: WRDA 64 W.R.GRACE

: N/A

: N/A

\$ RPCC SIAG RINKER
GRADE : 57 S.G.(SSD): 2.460

F.M : 2.40 S.G. (SSD): 2630

TYPE : CRUSHED LTMESTOHE

TYPS : SIICA SAHD

SPEC : AASHTO ME-85 TYPEII

SPEC : AASHTO MA 154

SPEC : ARSHTO MF 194 TYPE D

SPEC : H/A

SPEC : W/A

SPEC : ASTM C989

\section{HOT WEA THER DESIGH MIX}

\$ BL AST FURHACE SIAG

\begin{tabular}{|c|c|c|c|c|}
\hline $\begin{array}{l}\text { CEAUEN T \{KE LBS } \\
\text { COARSE AGG (KE) lls }\end{array}$ & $\begin{array}{r}298 \\
: 1607\end{array}$ & $\begin{array}{l}\text { SLUMNP RAFGE } \\
\text { AIR COHTEHT }\end{array}$ & $\begin{array}{l}: 7.00 \\
: 2.4 \%\end{array}$ & $\begin{array}{l}\text { TO } 9.00(\mathrm{~mm}) \text { IH } \\
\text { TO } 5.6 \%\end{array}$ \\
\hline $\begin{array}{l}\text { FTHE AFG (KE) LBS } \\
\text { AIR EFT ADLCX(m) } 02\end{array}$ & $\begin{array}{r}1053 \\
: \quad 75\end{array}$ & $\begin{array}{l}\text { URIT WETGHT (HEt) } \\
\text { WC RAT } 10 \text { (plat) }\end{array}$ & $\begin{array}{l}: 139.7 \\
: 0.41\end{array}$ & $\begin{array}{c}\text { (KE /MS)PCF } \\
\text { (KEKE) LBSLB }\end{array}$ \\
\hline $\begin{array}{l}\text { 1ST ADMOXTURE(mi)oT } \\
\text { 2HD ADMIX(m) OZ }\end{array}$ & $\begin{array}{rr}238 \\
: \quad 0\end{array}$ & $\begin{array}{l}\text { WC PATIO (Fi H) } \\
\text { THED YIELD }\end{array}$ & $\begin{array}{l}: 0.41 \\
: 2700\end{array}$ & $\begin{array}{l}\text { (KE)KE)LBSLB } \\
(M,) C U F T\end{array}$ \\
\hline 3PD ADMUX (mi) OZ & 0 & & & \\
\hline WA TER (mI) GAL & 37 & \multicolumn{3}{|c|}{ PRODUCER TEST DATA } \\
\hline WA TER (KE) LBS & 308 & THLORDE COHT & $: 0.1$ & $(K \sin )$ LBCY \\
\hline \multirow[t]{4}{*}{ FLY ASH (KE) LBS } & 447 & SLURDP & $: 75$ & (MAd) IN \\
\hline & & AIR CONTEXT & $: 36$ & $\%$ \\
\hline & & TEMAPERA TURE & $: 97$ & $\mathrm{DEG}(\mathrm{C}) \mathrm{F}$ \\
\hline & & \multicolumn{3}{|c|}{$\begin{array}{l}\text { COMPRESSTVE STRENGHT (MPA)PSI } \\
\text { 28-DAY : } 7740 \text { PSI }\end{array}$} \\
\hline
\end{tabular}

Table 3.2 Mix Design for Phase II 


\subsection{CONCRETE TRUCK MIXER}

The same standard ten cubic yard concrete truck mixer is used for all test batches. Rinker truck number 2964 and US DOT number 328986 is used in all test batches (Figure 2.2). The truck has a maximum capacity of $10 \frac{1}{2}$ cubic yards (drum volume is 473 cubic feet), an agitating speed of 2 to $6 \mathrm{rpm}$ 's, mixing speed of 12 to $16 \mathrm{rpm}$ 's, and holds 80 gallons of water. The truck is manufactured by McNeilus model KX6-414, serial number 7498 and is both NRMA and TMMB approved (Figure 2.3).

\subsection{METHODOLOGY}

The load sequence, or Attachment \#11 (Appendix F) used by the CSR Rinker plant has been previously discussed in Chapter 2. Still, there are some inconsistencies with the actual sequence and terminology. To avoid misinterpretation of batching terms, the actual load sequence of the mixing truck under the chute, will be described (Figure 3). First, with the drum mixer of the truck at charging mode (2 to $4 \mathrm{rpm}$ ), the headwater and admixtures are introduced into the truck by the plant machine. Second, the aggregates begin to discharge. While this continues, cementitious material begins to be ribboned in the truck via the chute. The aggregates continue to discharge though the chute, continuously during the whole process (even while the cement has stopped). Finally, the tail-water flows in the truck by the machine plant. 


\section{Methodology Plant Batching Procedure}

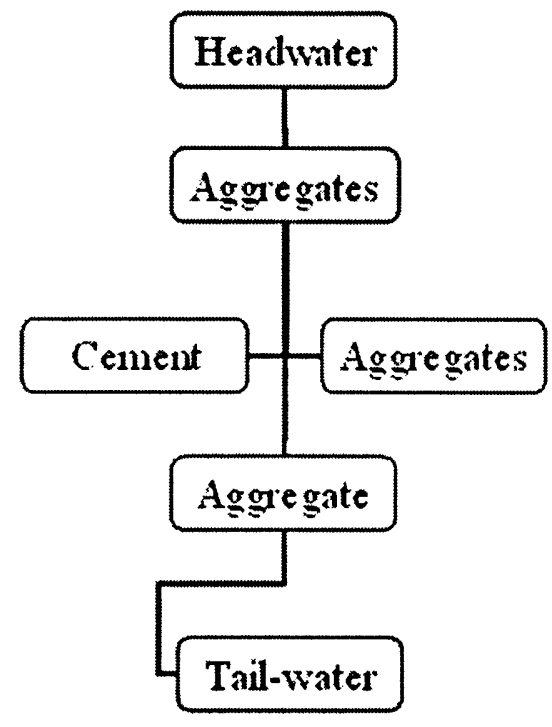

Discharge Secplence

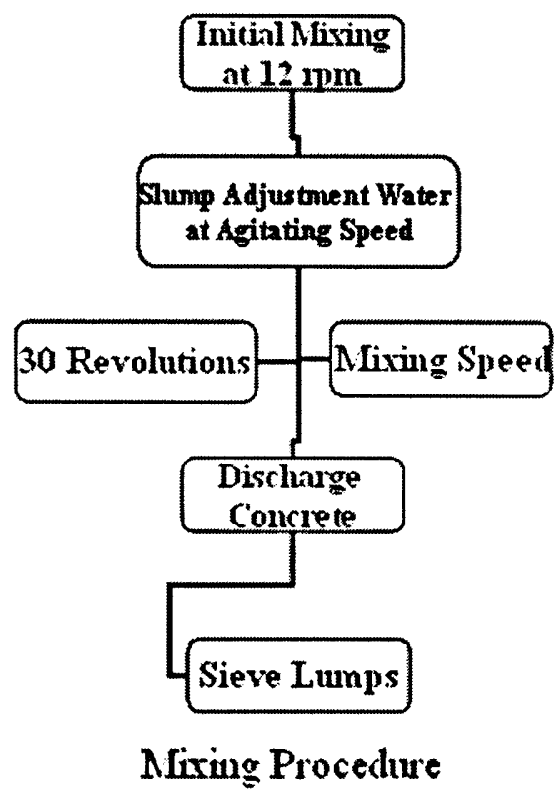

Figure 3 Batching Procedure

The truck mixes the concrete, using the initial revolutions $(40,50,70, \mathrm{ECT} \ldots)$ at $12 \mathrm{rpm}$. The slump water adjustment follows in order to convert the concrete slump from a 3 inch to a 7 or 8 inch slump, since the computer is batching a 3 inch slump concrete. The slump water is originally deducted from the total mix design water (along with the moisture compensation) (Appendix E). Subsequently, the slump water adjustment is manually fed into the truck drum not charged by the batching plant. (Slump adjustment accounted before batching and discounted of total water as jobsite allowable.) In all water additions, the truck mixer must be at charging speeds ( 2 to 6 rpm's). Subsequently, after 
any addition of water, the concrete must be mixed for an additional 30 revolutions at mixing speeds (12 rpm). Finally, the concrete is discharged and the cement lumps sieved.

\subsubsection{Phase I}

This part of the project consisted of 11 test batches performed during April and May 2001. Phase I was supposed to dictate a solution to the problem of cement lumps in high-slump concrete, but after careful consideration, it was determined that results of Phase I were inconclusive and more testing was necessary.

1) Load truck mixer with the specified concrete mix (Table 3.1).

Use the load sequence outlined above in Sections 3.4 or 2.8.3.

2) Vary the discharge rate, load size, the headwater percentage.

3) Perform three or four tests per variable. The load size: $3,5,7, \& 9$ cubic yards; the discharge rate: $150,200, \& 250 \mathrm{lbs} / \mathrm{sec}$; and the headwater percentage: $80 \%, 70 \%, \&$ $60 \%$.

4) Transport the mixed concrete in the truck to the slump stand. Mixing the concrete at a mixing rate of 12 revolutions per minute (rpm), but adding the necessary water at a charging speed of 2 to 4 revolutions per minute (rpm).

5) Take the necessary samples and measure the slump, density, temperature, and entrapped air in the concrete. Furthermore, make cylinder samples to determine the compressive strength at 7 and 28 days. Take the samples at the beginning and middle of each load (Figures 3.2 to 3.4 ) in order to meet ASTM requirements. 

A) Sampling Freshly Mixed Concrete: ASTM C172 (Figure 3.4).
B) Slump: ASTM C 143 (Figure 3.3).
C) Density and Unit weight: ASTM C 138.
D) Temperature: ASTM C 1064.
E) Entrapped air: ASTM C 173, C 231, C233 (Figure 3.4).
F) Compressive strength: ASTM C $31 \&$ C 39 (Figure 3.2).

6) Drive mixing truck to the discharge stand and discharge the mixed concrete into secondary mixing truck (Figure 3.7 to 3.8 ).

7) Sieve, collect and document the cement balls as they appear (Figure 3.8).

8) Take samples to be analyzed for composition and grading. Use ASTM sampling and testing methods ASTM (Vol. 04.02). (Sieve analysis ASTM C 136) (For lump samples see Figures in Chapter 4).

\subsubsection{Phase II}

Phase II was conducted in order to reaffirm phase I conclusions and to test new untested variants. Except for the variables under study the methodology is very similar.

1) Load truck mixer with the specified concrete mix (Table 3.2).

Use the load sequence outlined above in sections 3.4 or 2.8.3.

2) Vary the headwater percentage and mixing revolutions.

3) Perform three headwater percentage tests $(55 \%, 30 \%$, \& $20 \%)$ using 55 initial revolutions. Then, use the optimum headwater percentage to find the number of critical initial revolutions $(55,75$, or 100 revolutions). Code requires that after each water addition in all tests, 30 additional revolutions must be given to the mix at $12 \mathrm{rpm}$ 's. 
4) Transport the mixed concrete in the truck to the slump stand. Mix the concrete at a mixing rate of 12 revolutions per minute (rpm), but add the necessary slump water from the job allowable, at a charging speed of 2 to 4 revolutions per minute (rpm). Mix concrete for an additional 30 revolutions after slump adjustment at 12 rpm's.

Note: Steps 5 through 8 of Phase I are the same for Phase II.

\subsection{EXPECTED RESULTS}

Results are reported in terms of graphic charts and tables, as appropriate, to show the effects of the variables under study on the occurrence of lumps and balls in highslump ready-mix concrete. Test results are presented using tables and graphs that categorized the variables: load size, discharge rate, slump, percentage air entrapped, density, number of revolutions, concrete compressive strength (at 7 and 28 days), and number and size of balls are included in these tables.

Steps to be taken to avoid lumps and balls in concrete are recommended based on these results. Furthermore, reasons for the problem are pointed out and suggestions made based on these findings. The recommendations consider manufacturers procedures, so that they can be implemented in most or a majority of the plants operating in the State of Florida. 


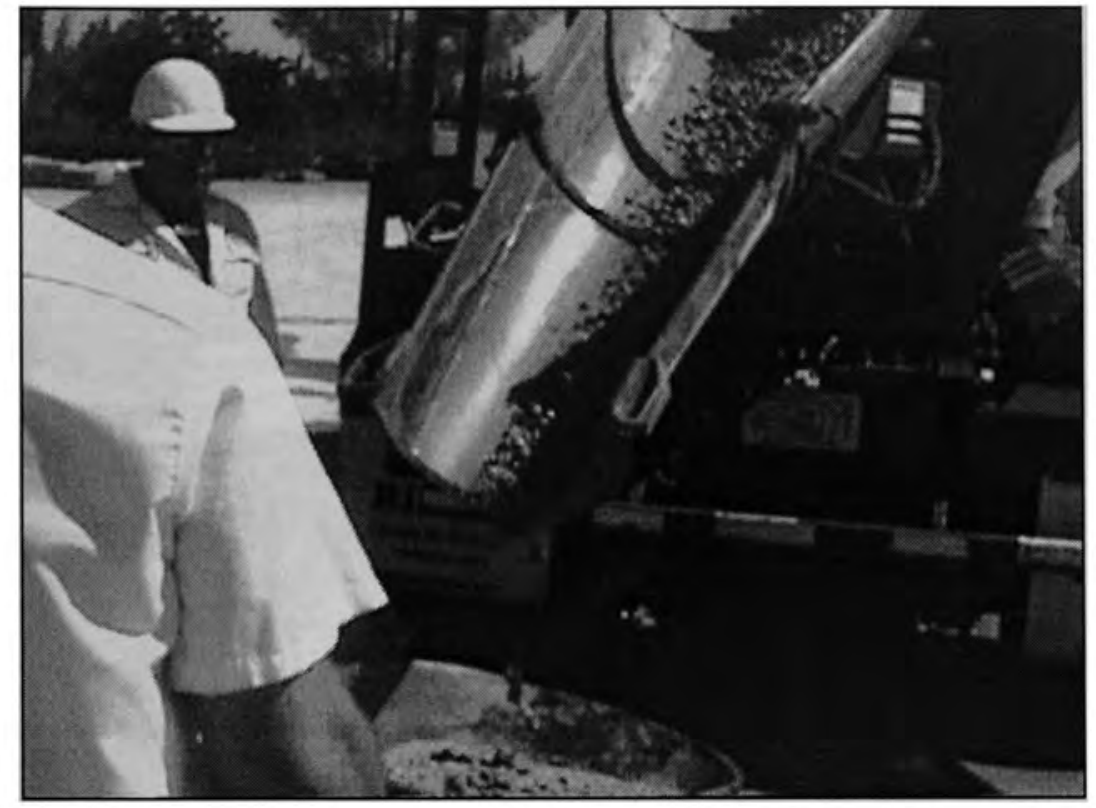

Figure 3.1 Concrete for Samples

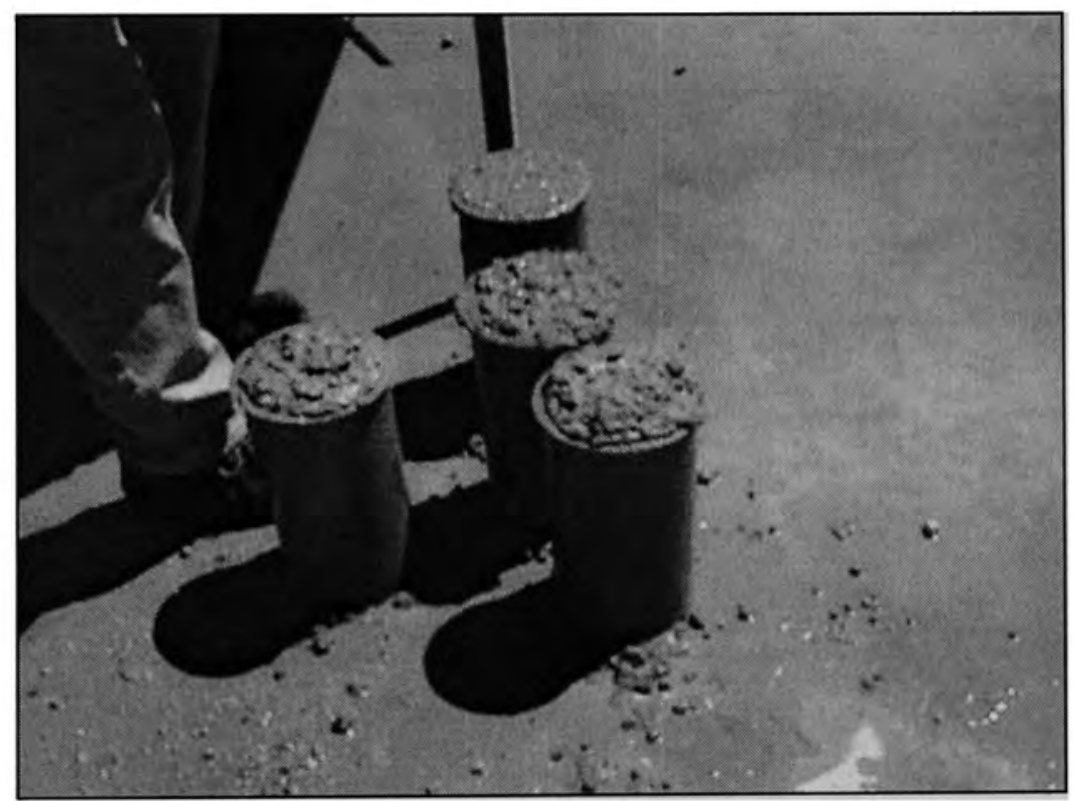

Figure 3.2 Concrete Cylinder Samples 


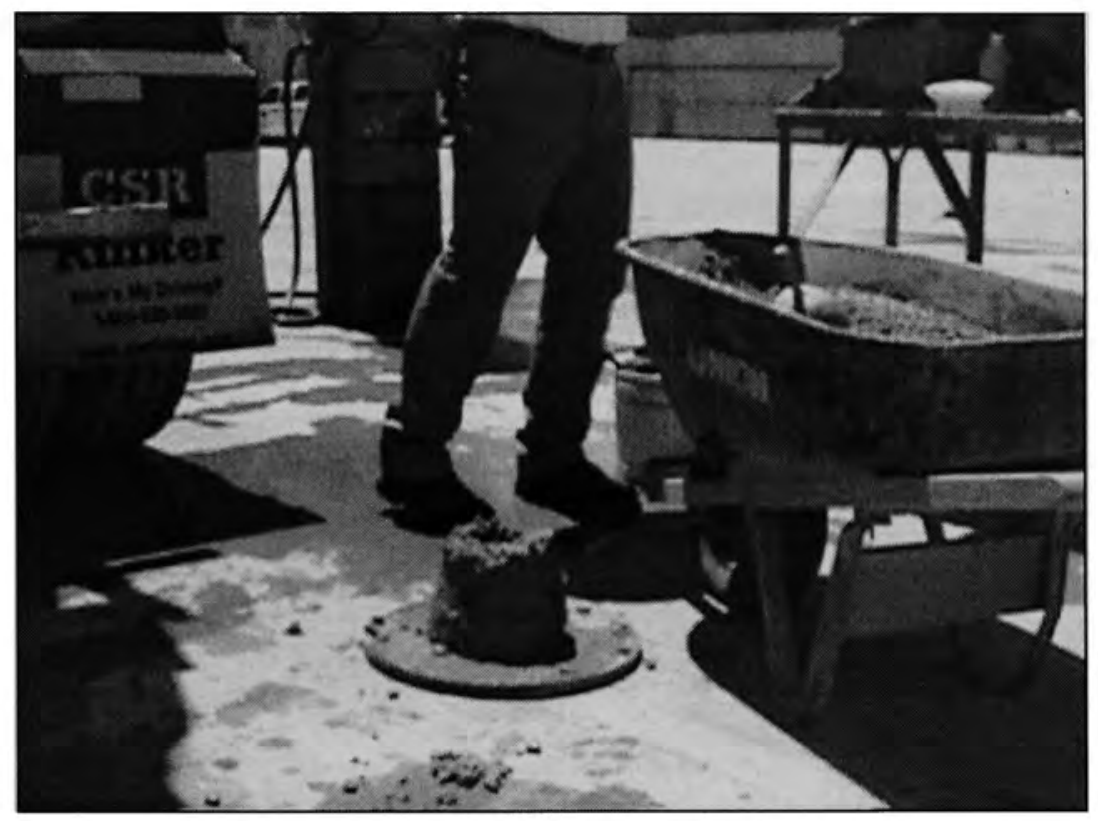

Figure 3.3 Concrete Slump Test

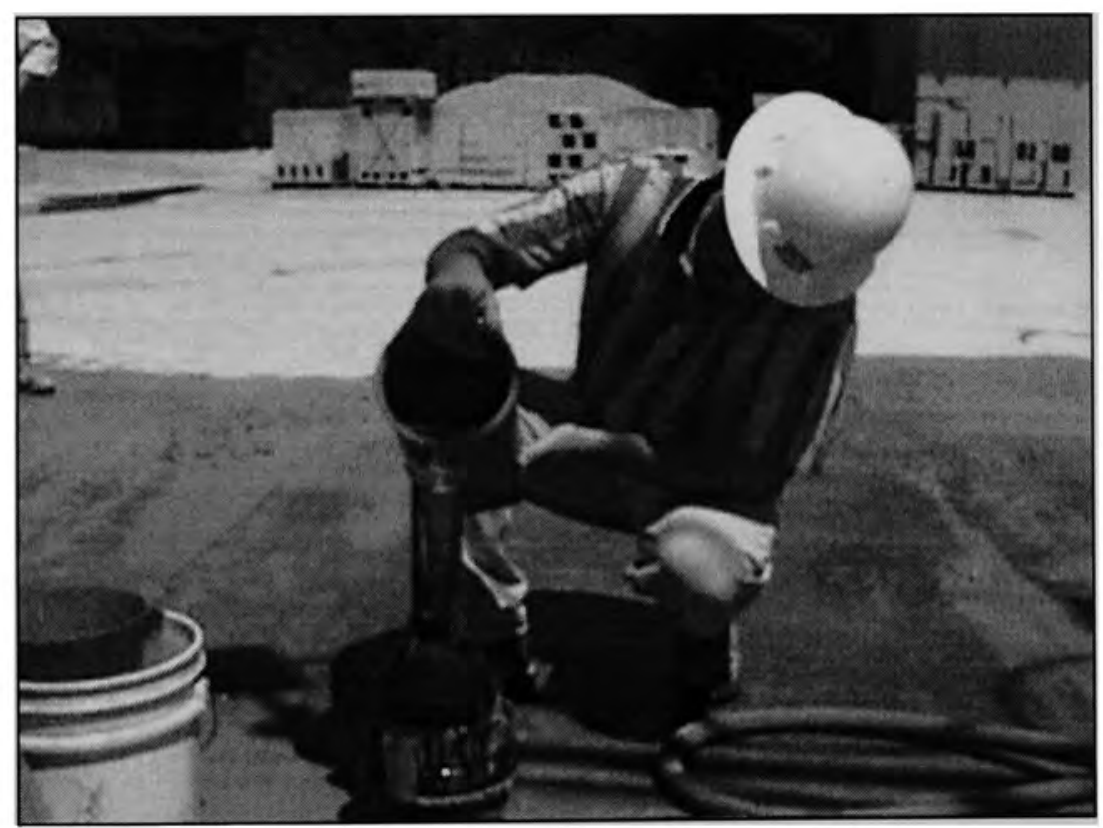

Figure 3.4 Concrete Air Content Test 


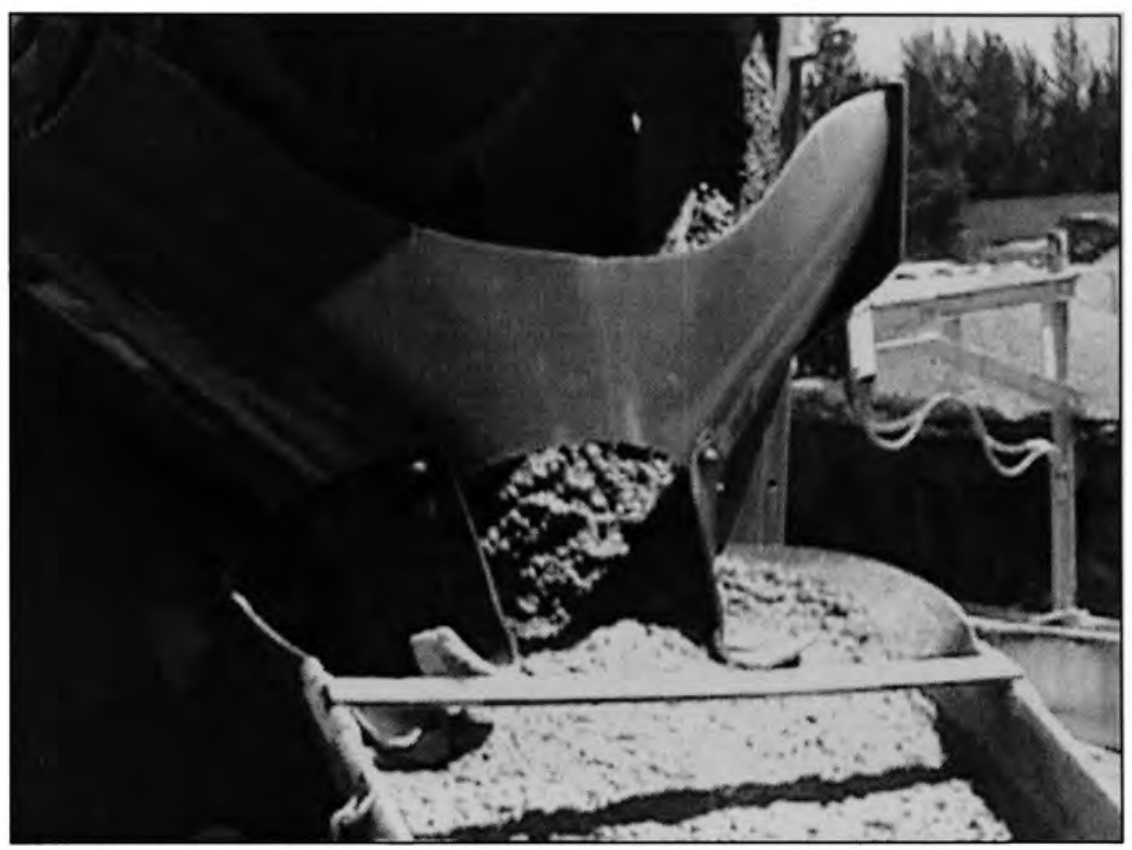

Figure 3.5 Concrete Discharge

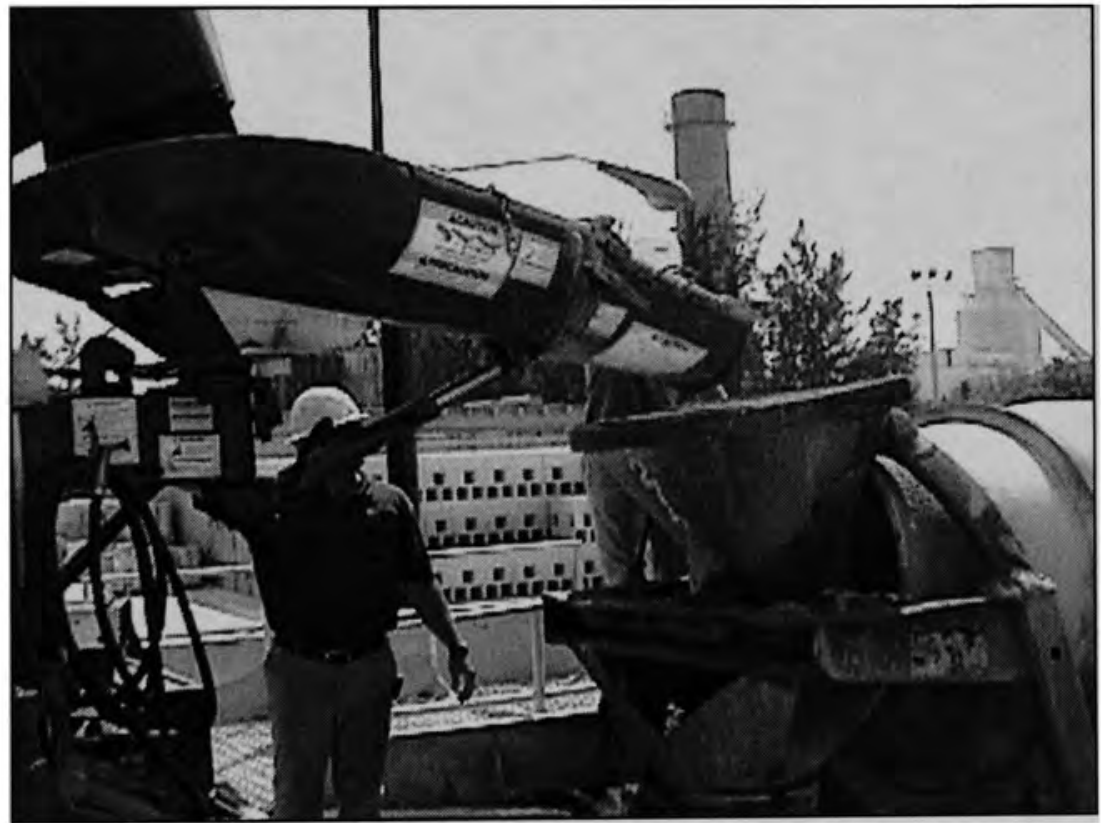

Figure 3.6 Discharging Concrete into Secondary Truck 


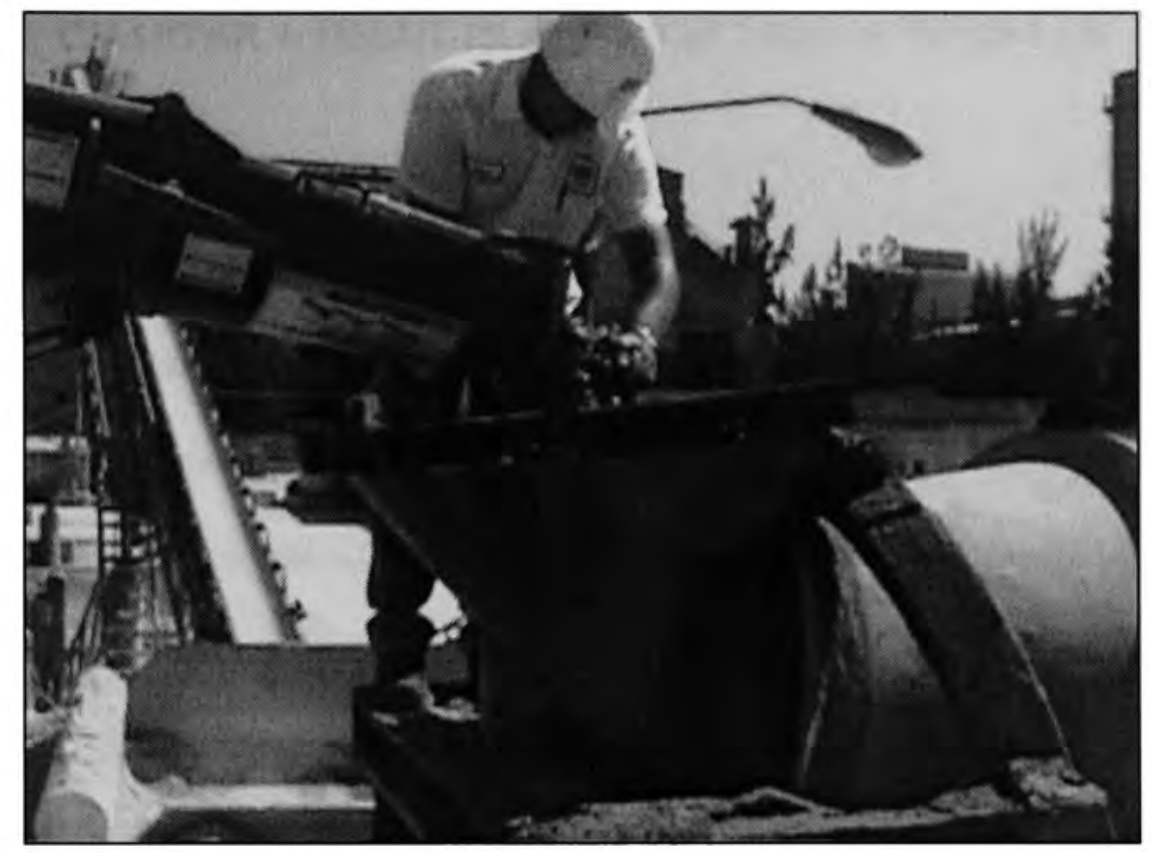

Figure 3.7 Concrete Cement Lump Retreival

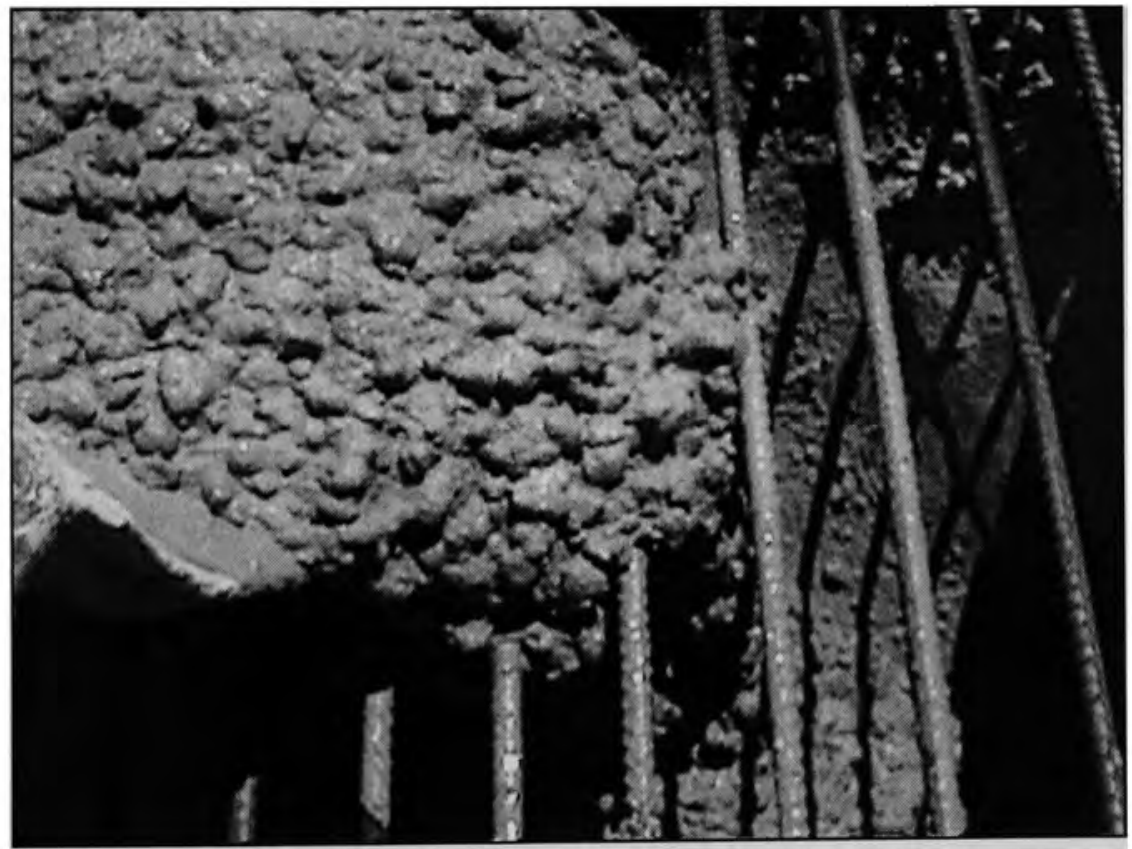

Figure 3.8 Sieving Concrete 


\section{CHAPTER 4: RESULTS AND ANALYSIS OF FINDINGS}

Initially, the scope of this research consisted of batching concrete tests to find the best possible mix homogeneity results for the FDOT high-slump concrete mix used for drilled-shaft foundations. Specific variables believed to cause cement lumps in highslump concrete were picked for testing in preliminary meetings at Florida International University. After these concrete test batches were conducted, the results demonstrated progress, but were still inconclusive. Therefore, a series of additional testing had to be performed. This was done in order to confirm primary results and to test more critical variables.

The first round of batches or (Phase I) consisted of twelve experimental batches. These tests were performed at the CSR Rinker, at their Sweetwater plant, during three days in the months of April and May 2001. A year later, during two days of March 2002, the second set of testing (Phase II) was carried out. Phase II consisted of five, nine cubic yard experimental batches, as stipulated in chapter three. All concrete test batches were consistent with the specified Florida Department of Transportation approved mix design number 06-0281 for high-slump concrete (Table $3.1 \& 3.2$ or Appendix C). Personnel from CSR Rinker, Florida International University, Florida State University, and Florida Department of Transportation were involved in the research project. These tests consist of loading the truck mixer, mixing the concrete, taking concrete samples and 


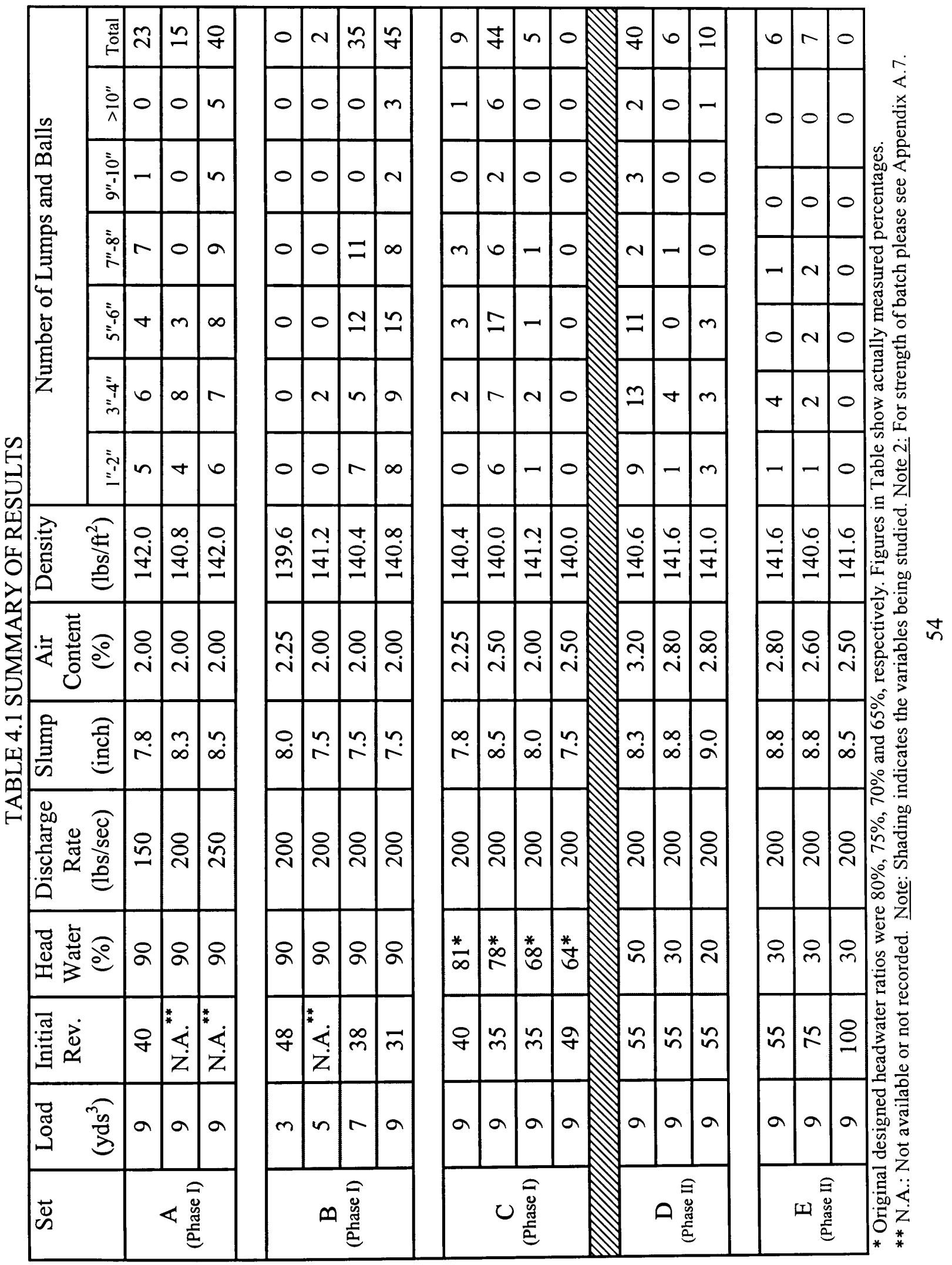




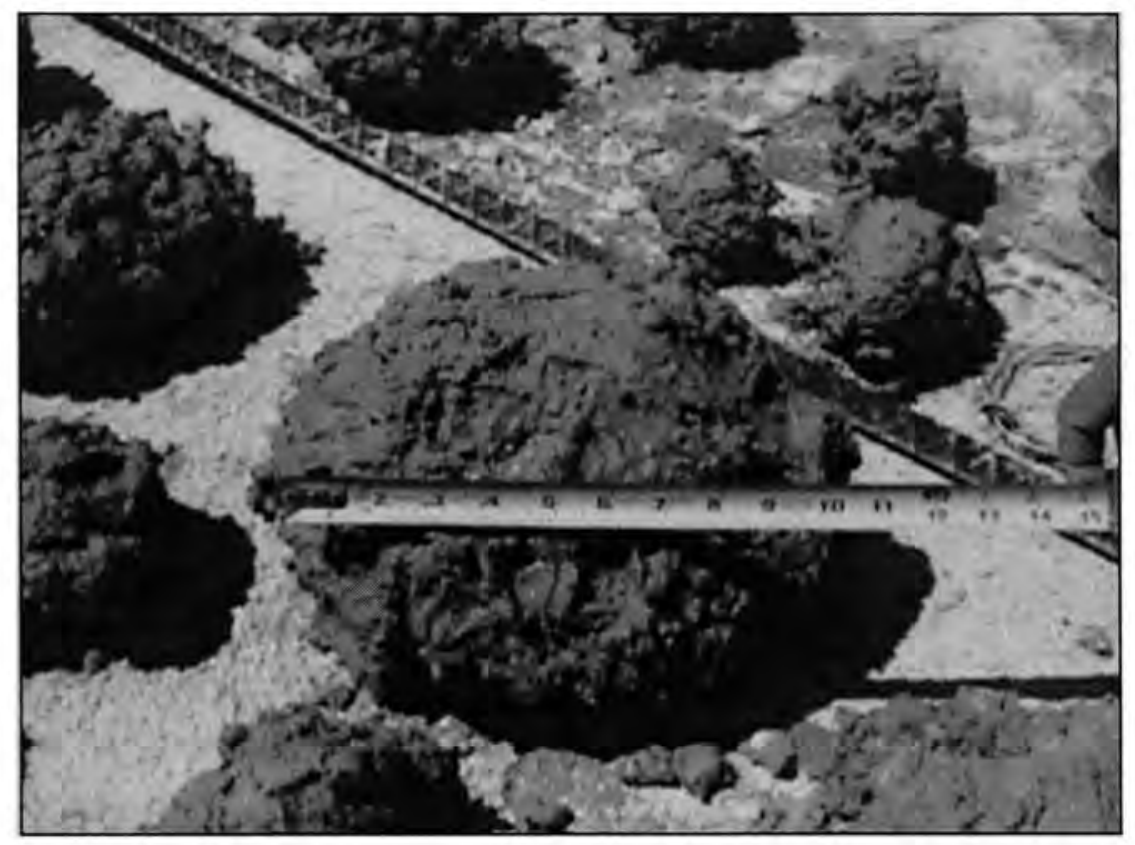

Figure 4.1 Ten Inch Cement Lump

readings, making any necessary water additions, and finally sieving and collecting the concrete lumps for documentation.

\subsection{TEST BATCHES}

The concrete test batches performed in this research, studied the following variables. For details of trial A, B, C, D, \& E please refer to Table 4.1.

\section{Phase I}

1) In trial " $A$ ", the discharged rate was varied from 150,200 , and $250(\mathrm{lb} / \mathrm{sec})$ and produced 23,15 , and 40 lumps respectively.

2) In trial "B", the size of the batch load was varied from 3, to 5, to 7, and 9 (cu yd) and produced $0,2,35$, and 45 lumps respectively. 
3) In trial " $\mathrm{C}$ ", four batches were charged with different headwater percentage of $81 \%, 78 \%, 68 \%$, and $64 \%$ and produced $9,44,5$, and 0 lumps respectively.

\section{Phase II}

4) Two trials of results or five 9 cubic yard batches were performed each at a discharged rate of $200 \# / \mathrm{sec}$.

5) In trial " $D$ " is a continuation of phase I headwater tests. The critical headwater content was attained, by using variations of $50 \%, 30 \%$, and $20 \%$ of headwater ratio and produced 49,6 , and 10 lumps respectively.

6) In trial "E", the optimum headwater content was used to find the most favorable initial mixing revolutions from 55,75 , and 100 produced 6,7 , and 0 lumps respectively.

\subsubsection{Test Batches of Varying Discharge Rate}

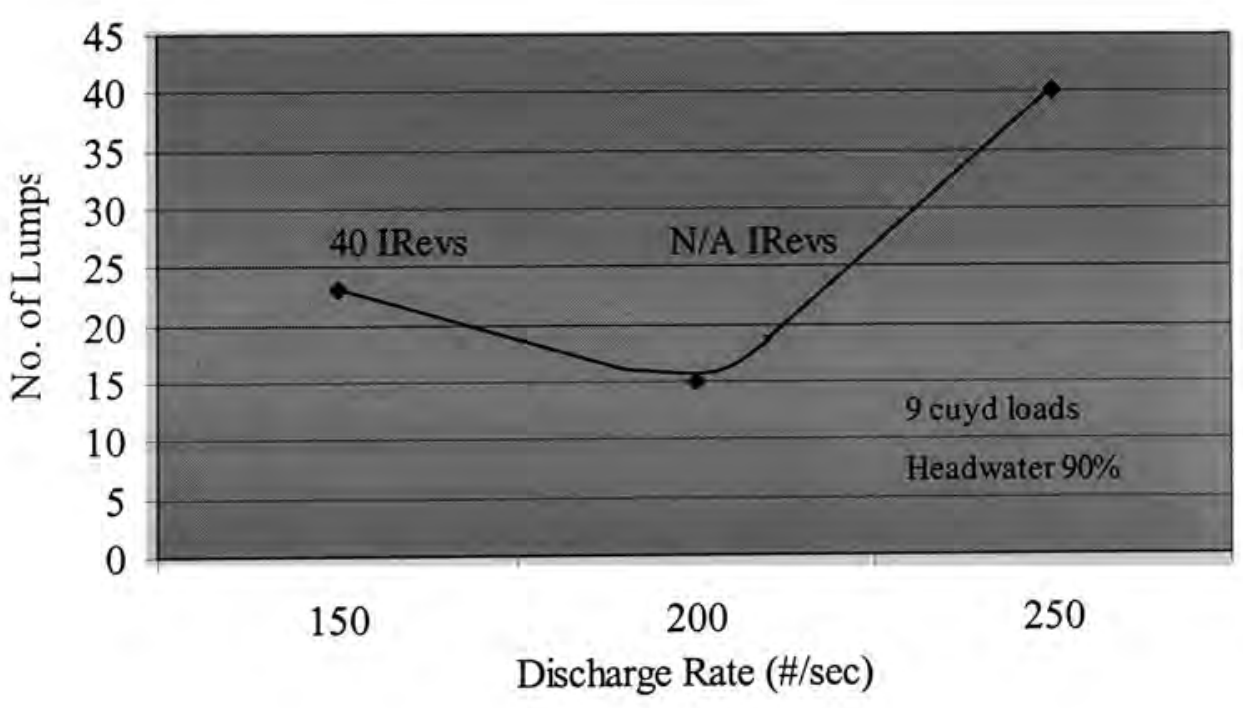

Figure 4.2 Trial A: Discharge Rate 
Trial "A" consisted of three batch trials with variations of the discharge rate as chapter three stipulated. The "discharge rate" $(\mathrm{lbs} / \mathrm{sec})$, refers to the speed at which the materials exit the loader through the chute into the mixing truck. The discharged rate results are illustrated in Figure 4.2.

The batches of trial A, or the discharge rate tests, had a volume of 9 cubic yards, a $90 \%$ headwater ratio, and met requirements of slump, air content, density, and strength (Appendix E). Figure 4.2 seems to indicate that the second test batch of $200 \mathrm{lb} / \mathrm{sec}$ resulted in fewer cement lumps of smaller diameters. Figures 4.1 and 4.4 are samples of one cement lump from the $250 \mathrm{lb} / \mathrm{sec}$ discharge. Besides having the greatest number of cement lumps, this trial batch produced the largest sized lumps of all trials. It seems that the materials were loaded too fast. Therefore, the rapid discharge improperly combines the fluid concrete and does not allow for a gradual introduction of materials in to the truck mixer, which would create a better mix.

Information on the number of initial and total revolutions is unavailable, except for test 1 batch $(150 \mathrm{lb} / \mathrm{sec})$, which was given 40 initial revolutions prior to slump water adjustment (Figure 4.3). Nevertheless, one may presume that initial mixing revolutions did not differ much in this set of trial batches, to have a decisive effect in the mix. No additional mixing revolution information is available. Initial sets of batches appear to indicate an optimal discharge rate of materials in the truck mixer of $200 \mathrm{lb} / \mathrm{sec}$, which will be used for all other trials. 


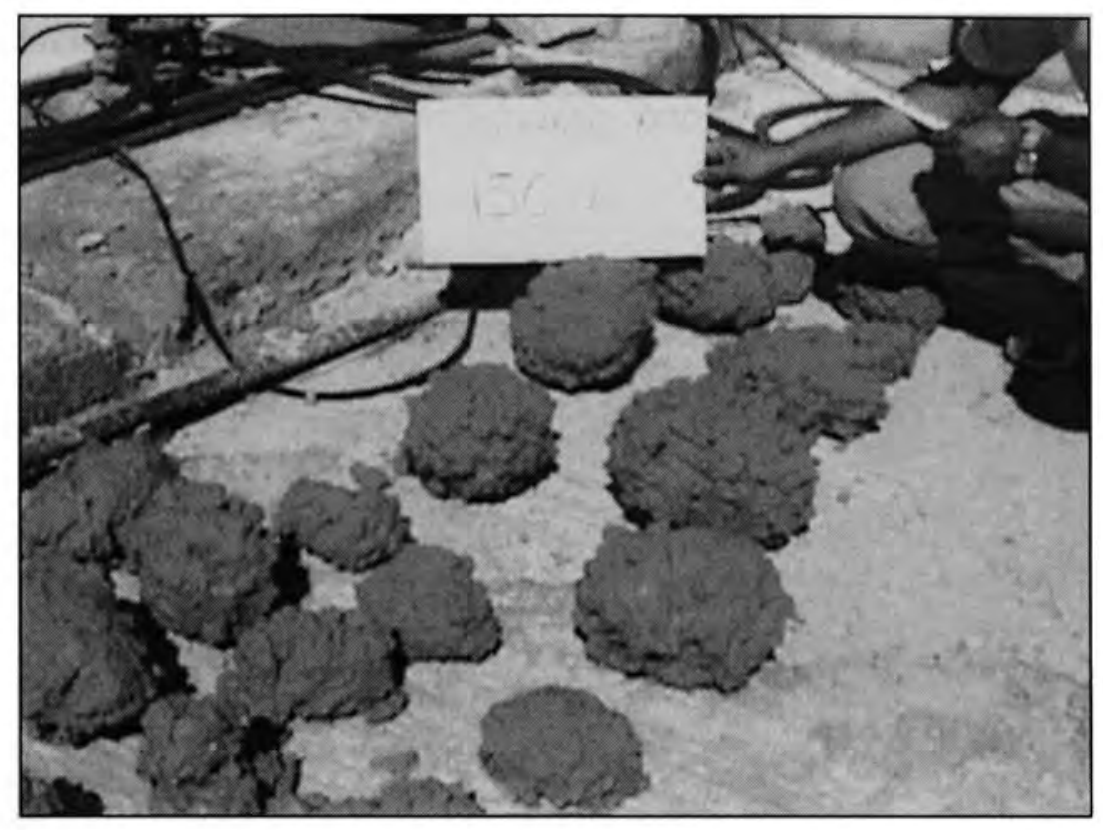

Figure 4.3 Cement Lumps of $150 \mathrm{lb} / \mathrm{sec}$ Batch

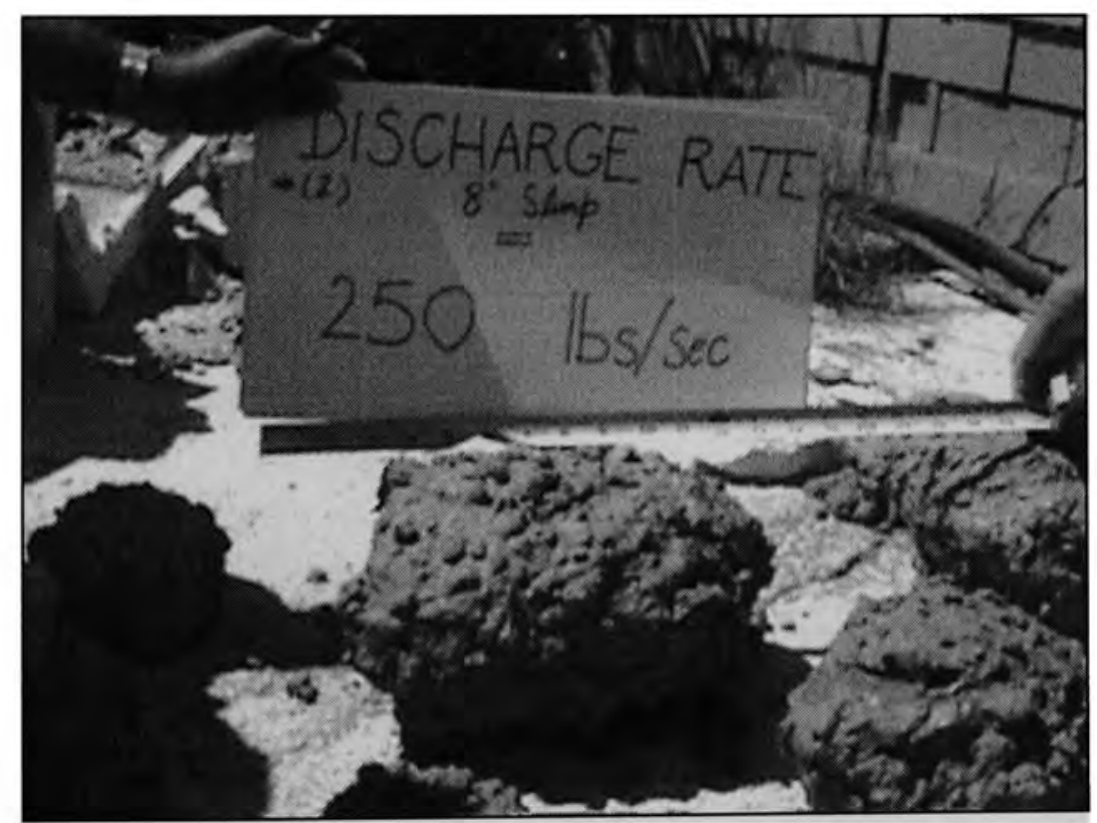

Figure 4.4 Cement Lump of $250 \mathrm{lb} / \mathrm{sec}$ Batch 


\subsubsection{Test Batches of Varying Load Size}

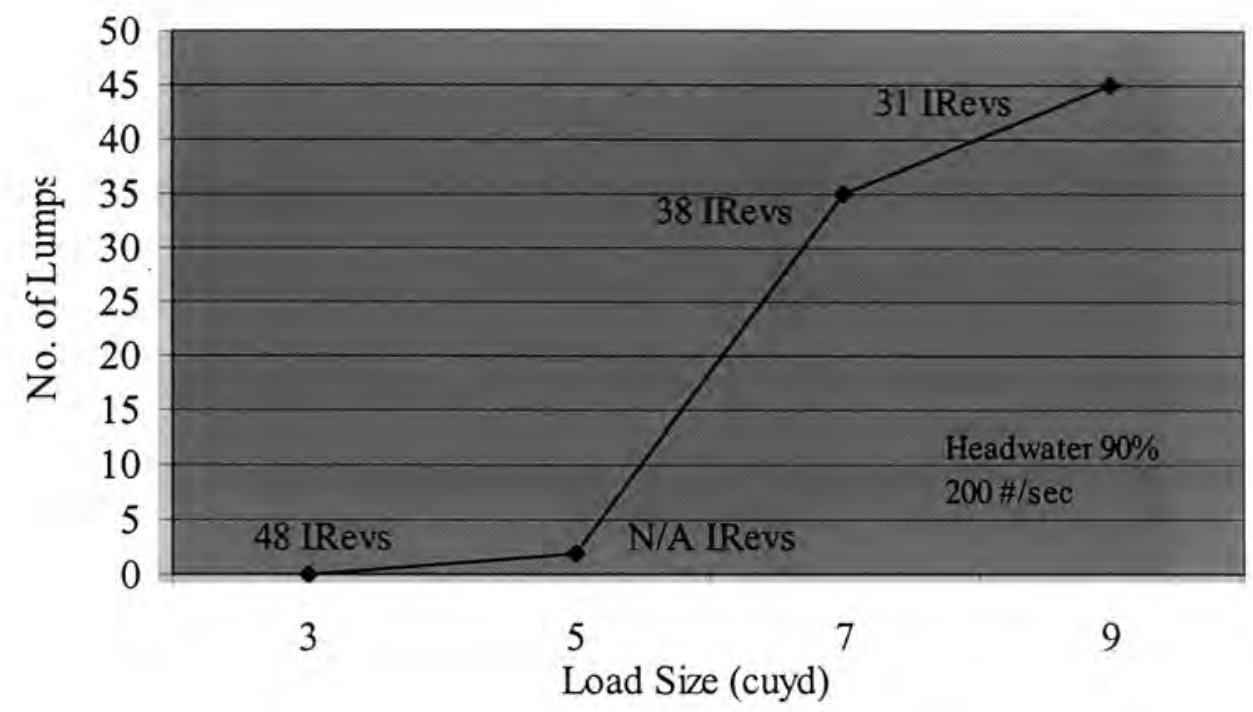

Figure 4.5 Trial B: Load Size

Trial "B" consisted of four experimental batch trials with load size variations of 3 , 5,7 , and 9 cubic yards. Trial B had a $90 \%$ headwater ratio, but of very different water amount, due to different load size. Slump, air content, density, and compressive strength all meet requirements (Appendix E).

The 7 and 9 cubic yards batches had plenty of cement lumps sieved from their composition (Figure 4.6). The 3 and 5 cubic yards batches had no, or very few, visible lumps. This is mainly because their small material content is easily mixed in a drum designed for 3 times the volume of material. Figure 4.5 illustrates an optimum load size 
between 3 to 5 cuyd, which if a double batching procedure was being used, these load sizes would serve as favorable values. However, this practice is very time consuming and highly discouraged by Mr. Gaynor (Chapter two, Gaynor, 1973).

Tests proved inconclusive for the purpose of this research, principally because a load size of 3 to 5 cubic yards is not commercially feasible for a plant batching 9 cuyd loads. Initial revolutions did not differ greatly between batches, so no indication of critical revolutions can be deduced. Moreover, if the results are normalized (load size divided by number of lumps) the ratio is equal to $20 \%, 20 \%, 25 \%$, and 0 . So the results are constant and a 9 cubic yard load is taken as critical because it is more commercially feasible.

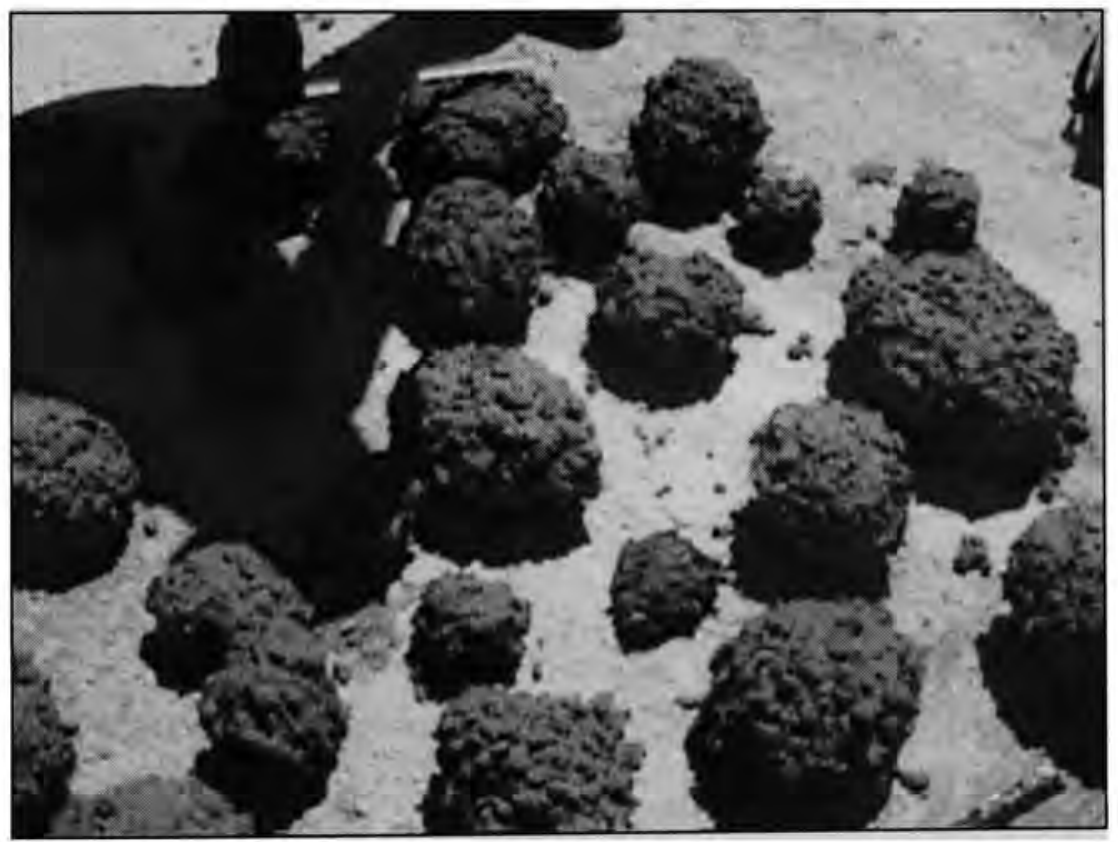

Figure 4.6 Cement Lumps from 7 cuyd Load 


\subsubsection{Test Batches of Varying Head-Water Content}

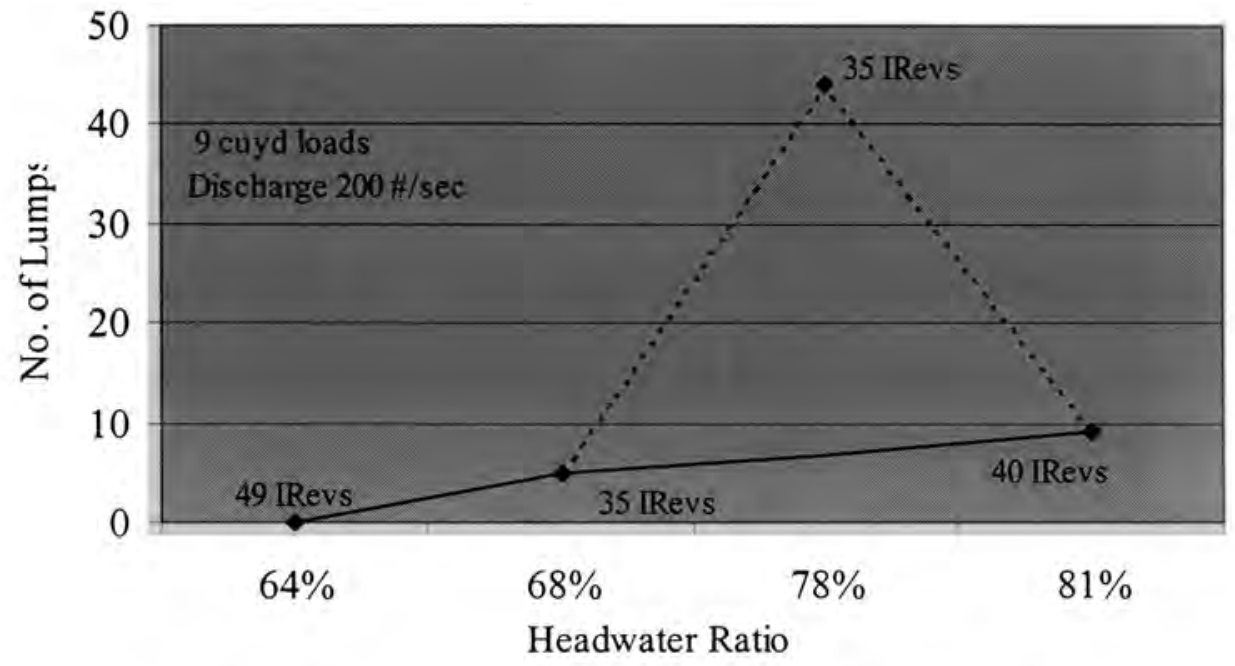

Figure 4.7 Trial C: Headwater Ratio

Trial "C" made up of four 9 cuyd batch trials discharged at $200 \mathrm{lb} / \mathrm{sec}$, which carried out variations of the headwater content. Four test trials of $81 \%, 78 \%, 68 \%$ and $64 \%$ initial headwater content were batched (originally planed to be 80,70 , and 65 percent). Actual headwater ratios are slightly different. Except for the first batch $(90 \%)$ the differences are small, but the actual headwater percentages are used. Slump, air content, density, and compressive strength all met requirements (Appendix E). 
As illustrated by Figure 4.7 the first two batches ( $81 \%$ and $78 \%$ ) of trail $\mathrm{C}$ had similar headwater ratios, but the second batch (78\%) increased dramatically in the number of cement lumps by 36 (Figure 4.7). Results seem to indicate that the initial mixing revolutions did not play a major role in the increase of cement lumps. Trial $\mathrm{C}$ had $40,35,35$, and 49 initial revolutions prior to slump stand water additions and the slump water adjustment was $7,9,40$, and 40 gallons in batches $81 \%, 78 \%, 68 \%$, and $64 \%$ respectively (Appendix E). The wide range of water additions along with a lack of constant and accurate mixing revolutions do not allow for credible conclusions.

However, Figure 4.7 almost depicts the gradual decrease of cement lumps with a lower headwater ratio. The $78 \%$ headwater ratio batch produced 44 cement lumps. This out-laying trial (batch $78 \%$ ) could have been caused by insufficient mixing revolutions and improper water additions. So if omitted from the trial and not represented in Figure 4.7, the graph would increase the number of cement lumps almost linearly with an increase of headwater. The $81 \%$ headwater ratio test batch produced 9 cement lumps. The $68 \%$ headwater ratio produced 5 cement lumps. And the final batch of trial $\mathrm{C}$ had a $64 \%$ and 0 cement lumps. Except for the batch of $78 \%$ headwater, the results seem to indicate a reduction of cement lumps with a lower headwater ratio. 


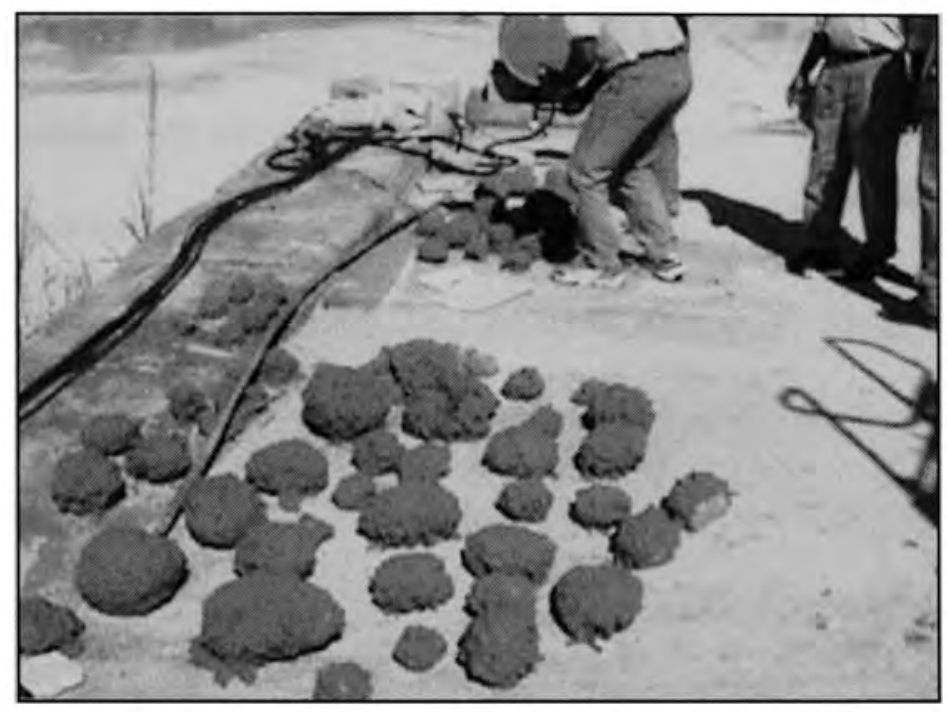

Figure 4.8 Cement Lumps in One Day of Testing of Phase I

\section{Phase II}

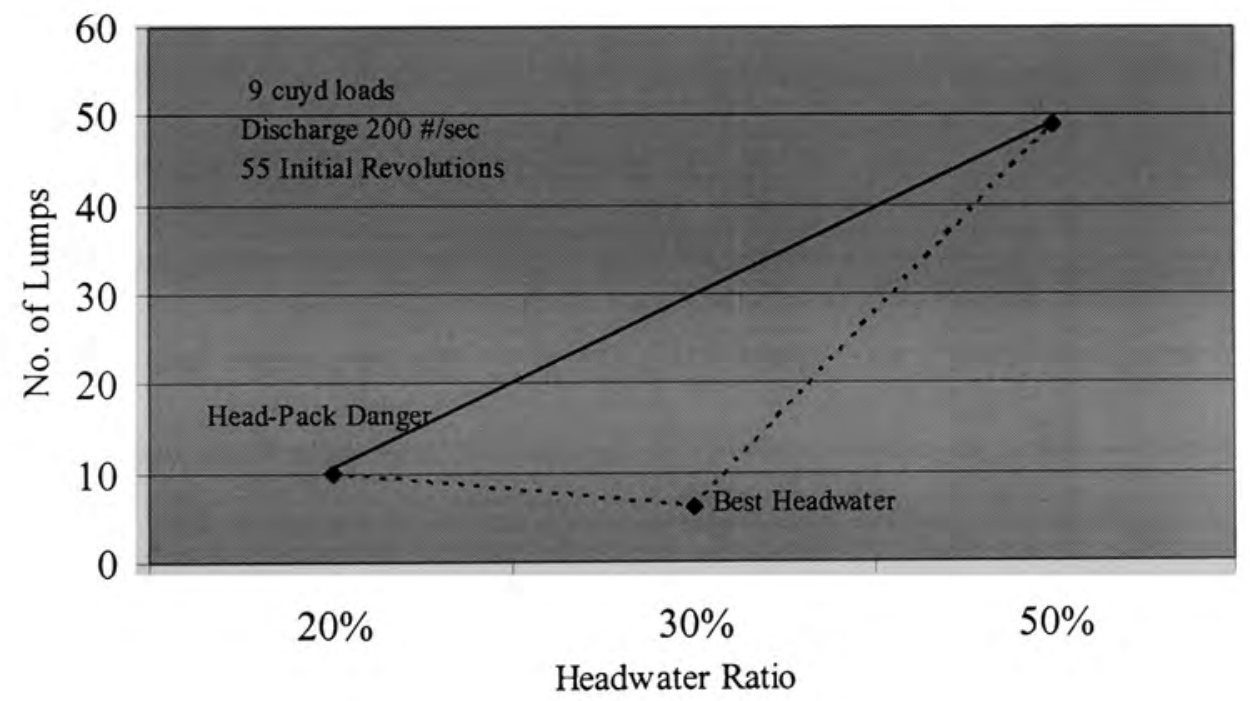

Figure 4.9 Trial D: Headwater Ratio 
The trial $\mathrm{D}$ was maintained to 55 initial revolutions prior to slump stand water addition and additional 30 revolutions, while the headwater content was decreased to even lower ratios of headwater content $(50 \%, 30 \%$, and $20 \%)$. Figure 4.9 illustrates an optimum headwater percentage of $30 \%$ (Figure 4.11 ). The great number of cement lumps in the $50 \%$ headwater batch tends to reveal a link of cement balls with low headwater ratio's and high initial revolutions. The $50 \%$ headwater (Figure 4.10 ) test proved too high (49 cement lumps) and the $20 \%$ too low (10 cement lumps) with all other variables constant (revolutions, discharge, load size, and water additions). Figure 4.9 seems to show almost a linear decrease of cement lumps with a diminish headwater ratios. But, since the $20 \%$ headwater test seem to demonstrate a tendency to create a head-pack in the drum, it was taken as an outlier and the $30 \%$ headwater ratio accepted as the optimum value.

The results of trial $\mathrm{D}$ seem to prove the previous conclusions of trial $\mathrm{C}$, that a lower headwater ratio would create less cement lumps. In addition, the sizes of the lumps were also reduced with a lower headwater ratio. Because of the extra care taken with the water additions and mixing revolutions, Phase II headwater results are more realistic. Therefore, an optimum headwater percentage of $30 \%$ is used for the next series of tests or trial E. 


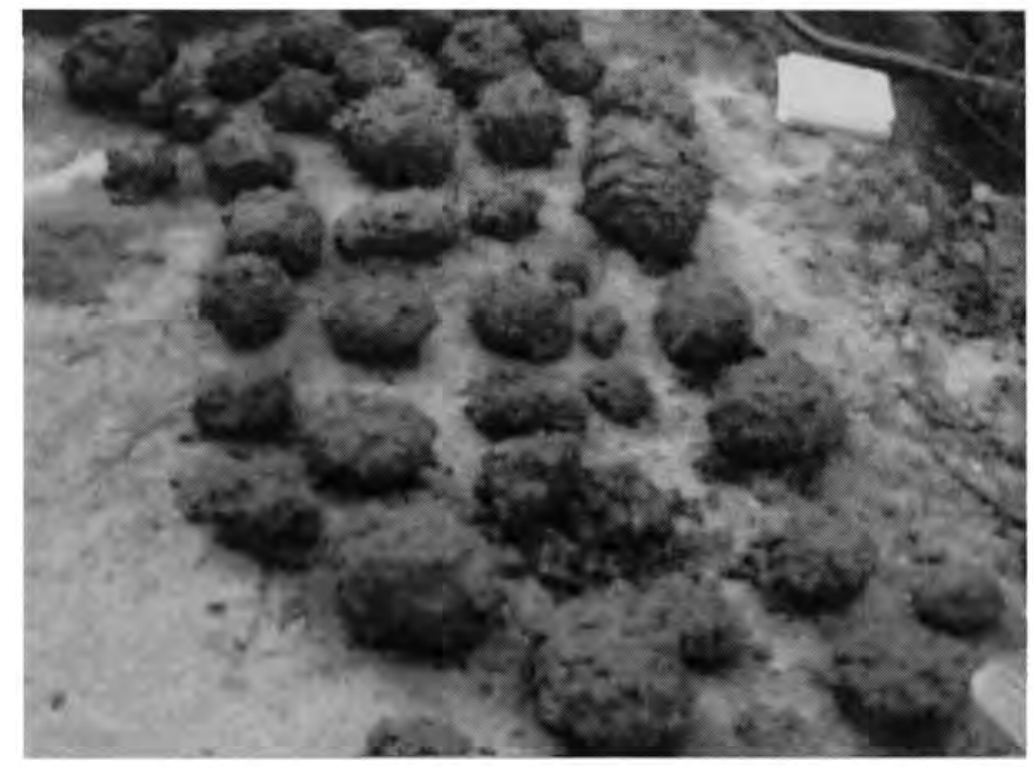

Figure 4.10 Cement Lump of $50 \%$ Headwater Ratio and 55 Initial Revolutions in Phase II

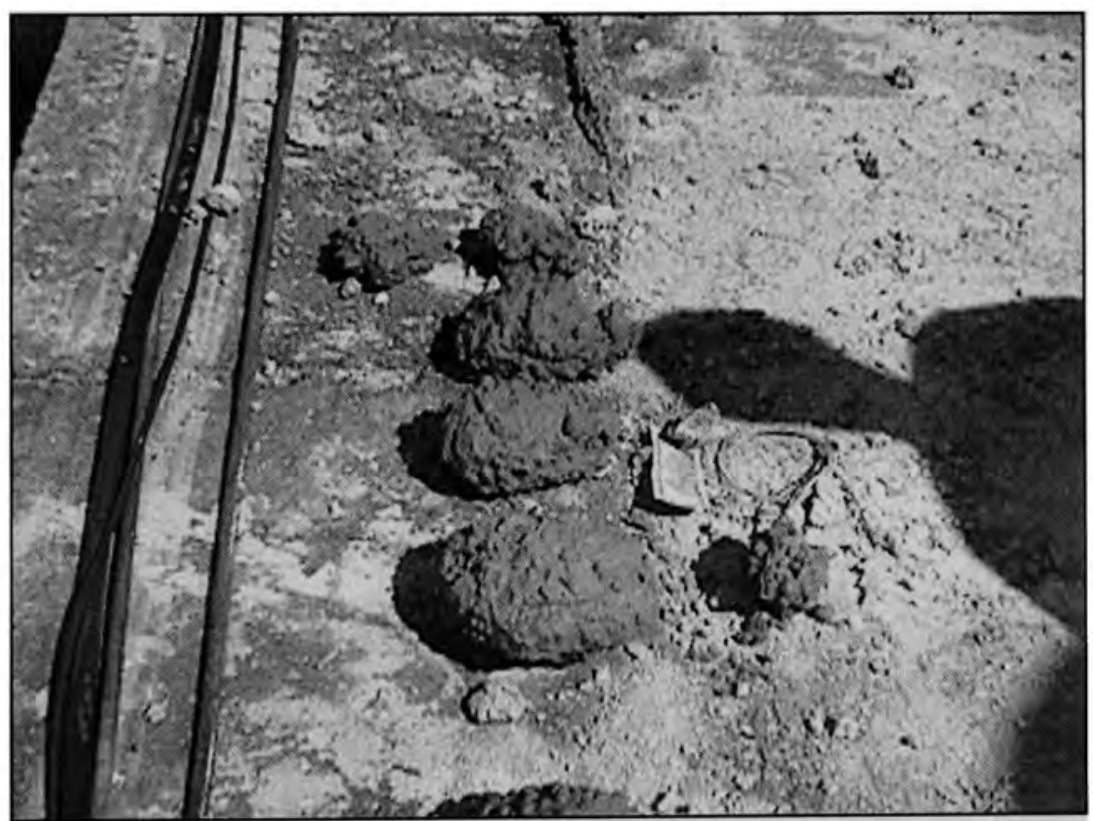

Figure 4.11 Cement Limp of $30 \%$ Headwater Ratio and 55 Initial Revolutions in Phase II 


\subsubsection{Test Batches of Varying Initial Revolutions}

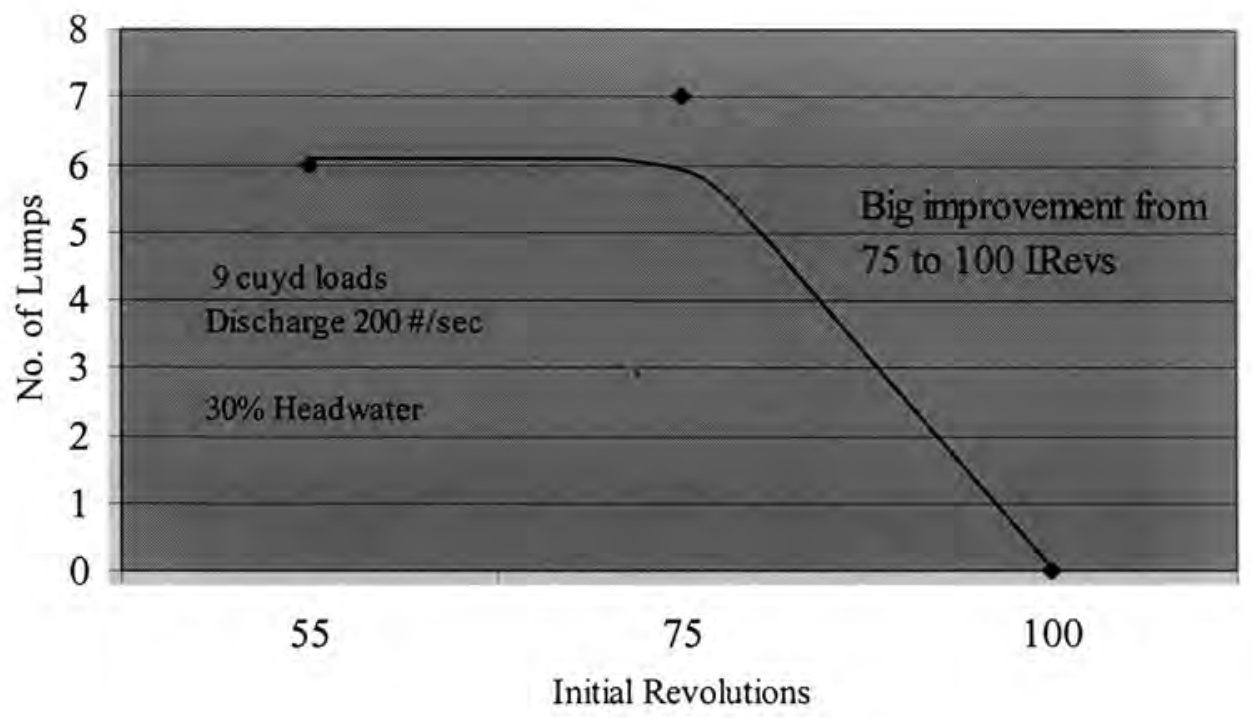

Figure 4.12 Trial E: Initial Mixing Revolutions

Using a headwater percentage of $30 \%$, a discharged rate of $200 \mathrm{lb} / \mathrm{sec}$, trial E tested $9 \mathrm{cu}$ yd loads with variations of the initial revolutions between 55,75 and 100 . The first batch of 55 initial revolutions had 6 cement lumps. The 75 initial revolutions had 7 cement lumps. The last batch of 100 the initial revolutions had 0 cement lumps. A considerable decrease of cement lumps is reflected by Figure 4.12 between 75 and 100 initial revolutions. Furthermore, Figure 4.12 seems to illustrate the optimum number of initial revolutions to be 100 , for a total of 130 mixing revolutions at $12 \mathrm{rpm}$. Code specifies a maximum of 100 revolutions to mix concrete; therefore, if suggestions are accepted, the specifications will have to be changed. The high number of mixing 
revolutions appears to provide preliminary confirmation for of a link between lower initial water amounts, higher initial revolutions, and fewer cement lumps.

\subsubsection{Headwater and Initial Revolutions}

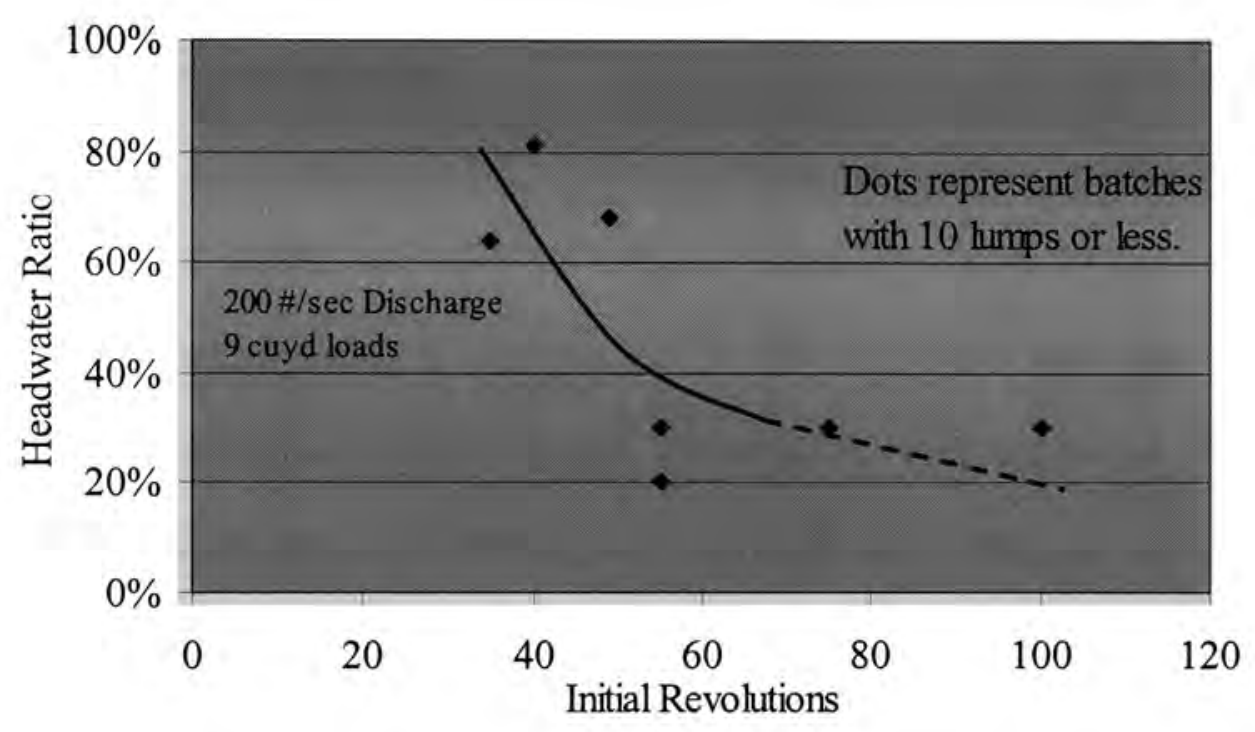

Figure 4.13 Initial Mixing Revolutions and Headwater Ratio

Graph 4.13 illustrates the initial revolutions versus the headwater ratio of both Phase I and Phase II, all $9 \mathrm{cu}$ yd batches discharged at $200 \mathrm{lbs} / \mathrm{sec}$ with less than ten cement lumps. These range from 35 to 100 initial revolutions and from 20 to 90 percent headwater content. 
Because these parameters (initial revolutions along with headwater content) were not precisely documented in Phase I the results of higher headwater content cannot be interpreted as perfect results. Proper mixing sequences, water additions, and revolutions were not accurately performed in Phase I. On the other hand, Phase II of the research did test and document these variables correctly. In spite of this, Figure 4.13 gives the impression of a relationship between high headwater content and few initial revolutions, and a reverse relation of low headwater content and high initial revolutions, both of which reflect fewer cement lumps.

Figure 4.13 depicts two optimum values of reversed values, for example a $65 \%$ headwater ratio and 50 initial revolutions, and a $30 \%$ headwater ratio and 100 initial revolutions, both produced 0 cement lumps. Moreover, a lower headwater ratio $(30 \%)$ and higher initial revolutions $(75,100)$ produced cement lumps of smaller diameters. It is this author's belief that due to the uncertainty of Phase I results and the smaller cement lumps found in Phase II, the relation of less headwater content and more initial revolutions will be suggested as the best batching procedure. Figure 4.13 illustrates a trend-line that is dashed under $30 \%$ headwater ratio; this is because a lower headwater ratio is prone to form head-packs and the headwater is therefore maintained at $30 \%$ 


\subsection{CEMENT LUMP SAMPLE GRADATION}

Grading samples were collected from both phases of study (Appendix E). Seven samples were selected to find the cement lumps composition and ascertain if all lumps have similar makeup (Figure 4.14) (Tables 4.2 and 4.3). A possible link between material composition and the abundance of cement lumps was believed to exist.

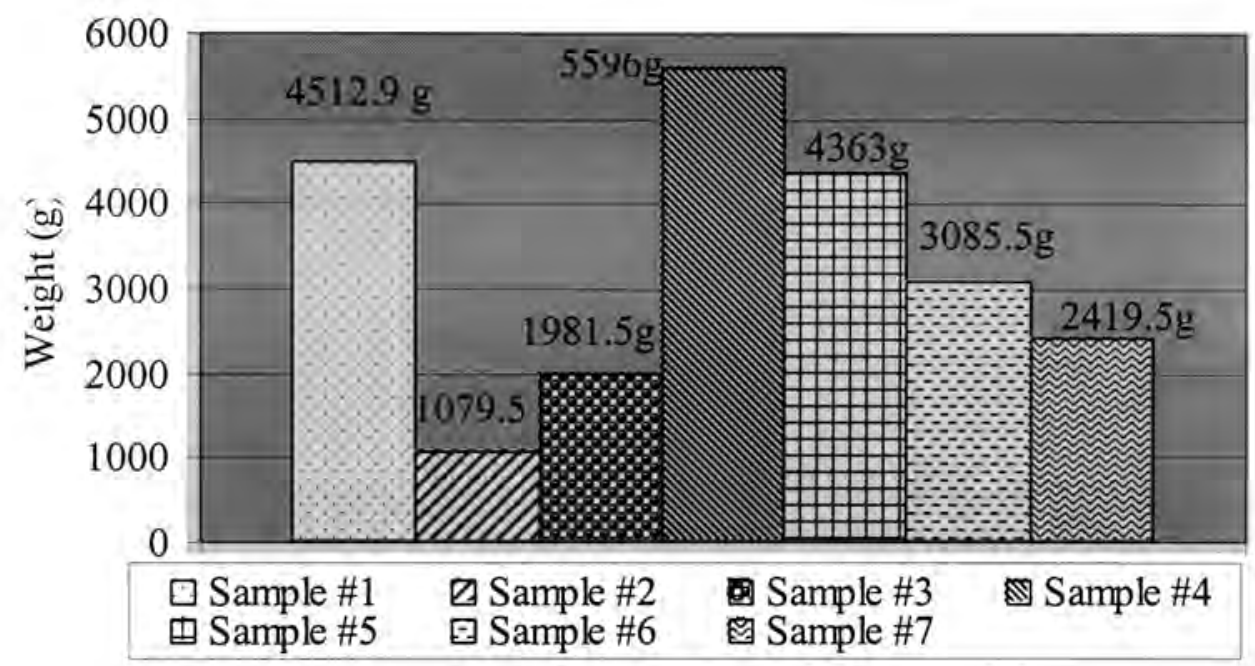

Figure 4.14 Grading Sample Weights

\subsubsection{Grading Samples Discussion}

The grading samples indicate that the solid materials in the cement lumps appear well graded, in other words the lumps consist of similar size aggregate and cement. The cement lumps range almost linearly; but between the maximum nominal size of $3 / 4$ inch and the No. 100 sieve (or 100 openings per square inch sieve) the grading graph indicates 
a reduction of slope. This demonstrates that $20 \%$ of the material is between small coarse aggregate and fine aggregates or coarse sand in the cement lumps. First, the Figure 4.15 illustrates that about $20 \%$ of the cement lumps is very fine sand or cement (No.100 to No. 30 sieves). Secondly, another $20 \%$ is fine aggregate or coarse sand. Third, the Figure illustrates an accumulation of $20 \%$ between the No. 30 and No. 4 sieves. Finally, the last $40 \%$ ranges from the No. 4 sieve and $3 / 4$ inch sieve. This is indicative of a cement lump composition of mostly small coarse aggregate and coarse sand. The samples used for grading weighed between 15 pounds and 3 pounds, but the average dry weight was around 8 pounds. Therefore, the coarse aggregate cannot be large in proportion with the fine aggregates in the cement lump

PERCENT THAT PAST THE SIEVE BY WEIGHT (7 SAMPLES, APPENDIX E)

\begin{tabular}{|c|c|c|c|c|c|c|c|}
\hline SIEVE & $\begin{array}{c}\text { Percent } \\
\text { Past } \\
\text { Sample\#1 }\end{array}$ & $\begin{array}{c}\text { Percent } \\
\text { Past } \\
\text { Sample\#2 }\end{array}$ & $\begin{array}{c}\text { Percent } \\
\text { Past } \\
\text { Sample\#3 }\end{array}$ & $\begin{array}{c}\text { Percent } \\
\text { Past } \\
\text { Sample\#4 }\end{array}$ & $\begin{array}{c}\text { Percent } \\
\text { Past } \\
\text { Sample\#5 }\end{array}$ & $\begin{array}{c}\text { Percent } \\
\text { Past } \\
\text { Sample\#6 }\end{array}$ & $\begin{array}{c}\text { Percent } \\
\text { Past } \\
\text { Sample\#7 }\end{array}$ \\
\hline$\uparrow^{\prime \prime}$ & 100 & 100 & 100 & 100 & 100 & 100 & 100 \\
\hline $3 / 4^{\prime \prime}$ & 92.1 & 91.6 & 92.8 & 92.6 & 97 & 99.2 & 95.6 \\
\hline $1 / 2^{\prime \prime}$ & 70.3 & 69.2 & 73.5 & 82.1 & 81.2 & 81.5 & 81.2 \\
\hline $3 / 8^{\prime \prime}$ & 57.2 & 58.6 & 61.2 & 72.2 & 71.2 & 72.9 & 69.1 \\
\hline$\# 4$ & 49.6 & 44 & 47.9 & 59.4 & 58.2 & 59.2 & 54.8 \\
\hline$\# 8$ & 48.9 & 41.4 & 45.2 & 56.7 & 55.7 & 56.4 & 52.1 \\
\hline$\# 10$ & 48.6 & 41.1 & 44.9 & 56.4 & 55.3 & 55.9 & 48.3 \\
\hline$\# 16$ & 46 & 38.4 & 42.1 & 52.9 & 51.7 & 52.3 & 22.8 \\
\hline$\# 30$ & 23.3 & 18.5 & 19.9 & 25.2 & 24.2 & 24.5 & 12.8 \\
\hline$\# 40$ & 12.7 & 10.4 & 10.9 & 14.2 & 13.6 & 13.5 & 7.7 \\
\hline$\# 50$ & 7.6 & 6.4 & 6.5 & 8.8 & 8.4 & 7.9 & 3 \\
\hline$\# 80$ & 2.1 & 2.7 & 2.5 & 3.9 & 3.6 & 2.9 & 1.7 \\
\hline$\# 100$ & 1.2 & 1.8 & 1.5 & 2.8 & 2.4 & 1.7 & 0.7 \\
\hline \#200 & 0.3 & 0.8 & 0.5 & 1.7 & 1.4 & 0.6 & 0.2 \\
\hline$M \& C$ & 0.1 & 0.4 & 0.1 & 1.1 & 0.9 & 0 & 0 \\
\hline
\end{tabular}

M \& C - Silts \& Clays / Percent past of samples are in order (1-7) in Appendix E

Table 4.2 Grading Samples: Percent Passing 


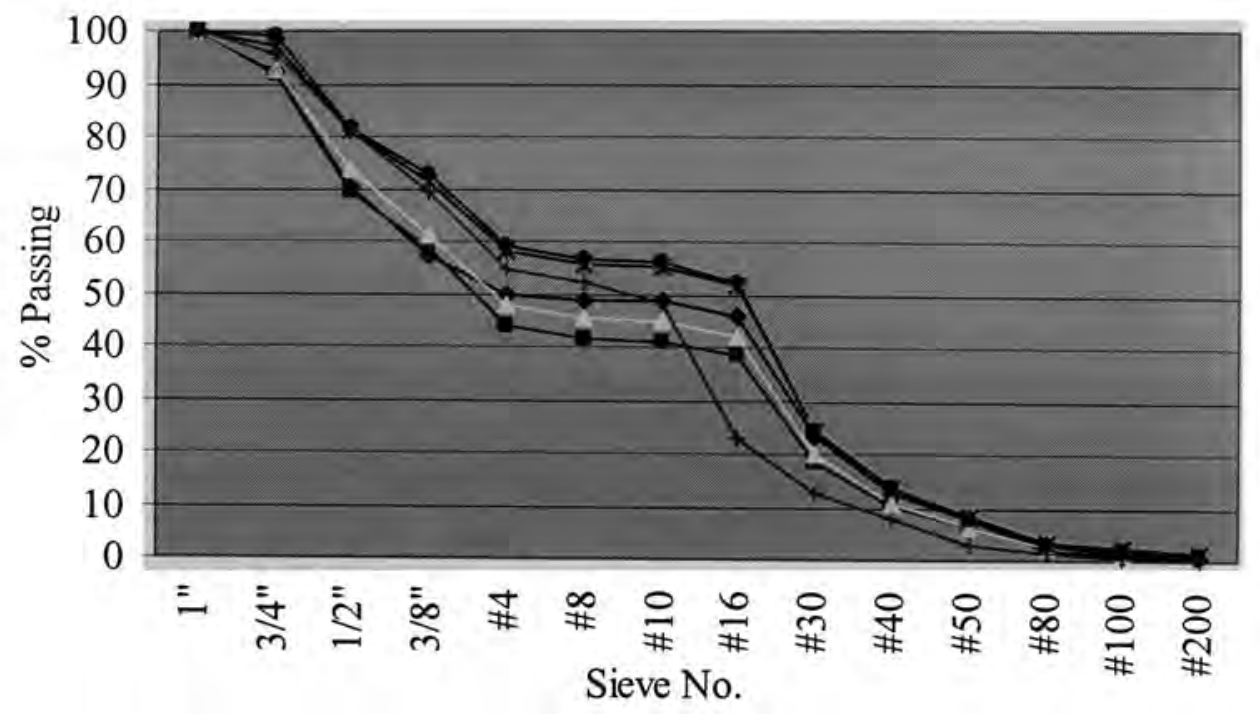

Figure 4.15 Percent Passing

PERCENT RETAINED ON INDIVIDUAL SIEVE, BY WEIGHT (7 SAMPLES, APPENDIX E)

\begin{tabular}{|c|c|c|c|c|c|c|c|}
\hline SIEVE & $\begin{array}{c}\text { Percent } \\
\text { Retained } \\
\text { Sample\#1 }\end{array}$ & $\begin{array}{c}\text { Percent } \\
\text { Retained } \\
\text { Sample\#2 }\end{array}$ & $\begin{array}{c}\text { Percent } \\
\text { Retained } \\
\text { Sample\#3 }\end{array}$ & $\begin{array}{c}\text { Percent } \\
\text { Retained } \\
\text { Sample\#4 }\end{array}$ & $\begin{array}{c}\text { Percent } \\
\text { Retained } \\
\text { Sample\#5 }\end{array}$ & $\begin{array}{c}\text { Percent } \\
\text { Retained } \\
\text { Sample\#66 }\end{array}$ & $\begin{array}{c}\text { Percent } \\
\text { Retained } \\
\text { Sample\#7 }\end{array}$ \\
\hline $11 / 2^{\prime \prime}$ & 0 & 0 & 0 & 0 & 0 & 0 & 0 \\
\hline $1^{\prime \prime}$ & 0 & 0 & 0 & 0.8 & 0.4 & 0 & 0 \\
\hline $3 / 4 "$ & 7.9 & 8.4 & 7.2 & 3.4 & 3 & 0.8 & 4.4 \\
\hline $1 / 2^{\prime \prime}$ & 21.8 & 22.4 & 19.3 & 14.5 & 15.8 & 17.7 & 14.4 \\
\hline $3 / 8^{\prime \prime}$ & 13.1 & 10.6 & 12.3 & 9.9 & 10 & 8.6 & 12.1 \\
\hline$\# 4$ & 7.6 & 14.7 & 13.3 & 12.8 & 13 & 13.7 & 14.3 \\
\hline$\# 8$ & 0.8 & 2.6 & 2.6 & 2.7 & 2.6 & 2.9 & 2.6 \\
\hline$\# 10$ & 0.2 & 0.3 & 0.3 & 0.3 & 0.4 & 0.4 & 0.5 \\
\hline$\# 16$ & 2.6 & 2.6 & 2.8 & 3.5 & 3.6 & 3.6 & 3.4 \\
\hline$\# 30$ & 22.7 & 20 & 22.2 & 27.6 & 27.5 & 27.9 & 25.5 \\
\hline$\# 40$ & 10.6 & 8.1 & 8.9 & 11 & 10.6 & 11 & 10.1 \\
\hline$\# 50$ & 5 & 4 & 4.5 & 5.4 & 5.2 & 5.6 & 5.1 \\
\hline$\# 80$ & 5.6 & 3.7 & 4 & 4.9 & 4.8 & 5 & 4.7 \\
\hline$\# 100$ & 0.9 & 0.9 & 1 & 1.2 & 1.1 & 1.2 & 1.2 \\
\hline$\# 200$ & 0.9 & 1 & 1 & 1 & 1 & 1 & 1.1 \\
\hline M \& C & 0.2 & 0.4 & 0.4 & 0.6 & 0.6 & 0.6 & 0.5 \\
\hline Total & 99.9 & 99.6 & 99.9 & 99.6 & 99.6 & 100 & 99.8 \\
\hline
\end{tabular}

M \& C - Silts \& Clays / Percent retained samples are in order (1-7) in Appendix E.

Table 4.3 Grading Samples: Percent Retained 
The next series of grading samples in Figure 4.16 depict the amount present or retained by each sieve. The percent retained also illustrates the accumulation of materials at the $1 / 2$ inch and No. 4 sieves; and at the No. 30 and No. 40 sieves, illustrating once again that the cement lumps are mostly composed of small coarse aggregate and coarse sand (Figure 4.16). Using the percent retained, the finesse modulus was attained for all samples and the average is 4.5 . Unfortunately, a link between the lumps composition and their formation was not determined.

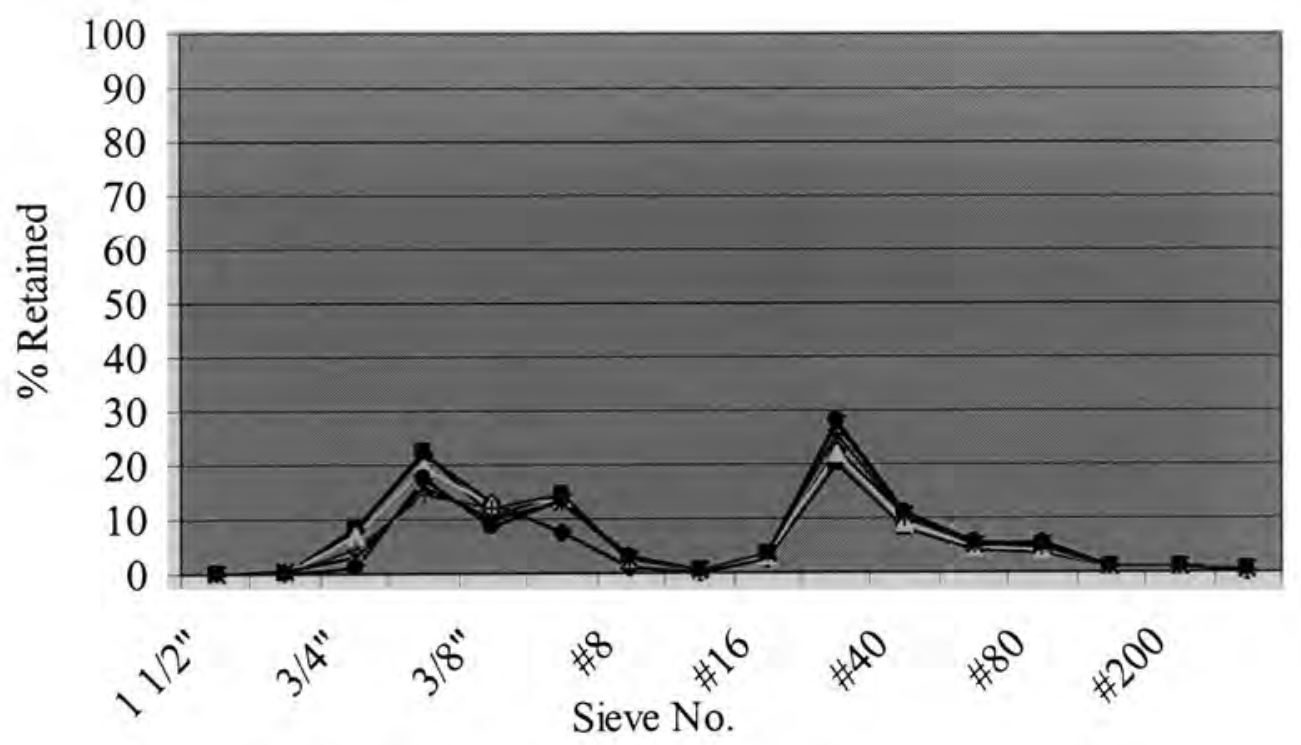

Figure 4.16 Percent Retained 


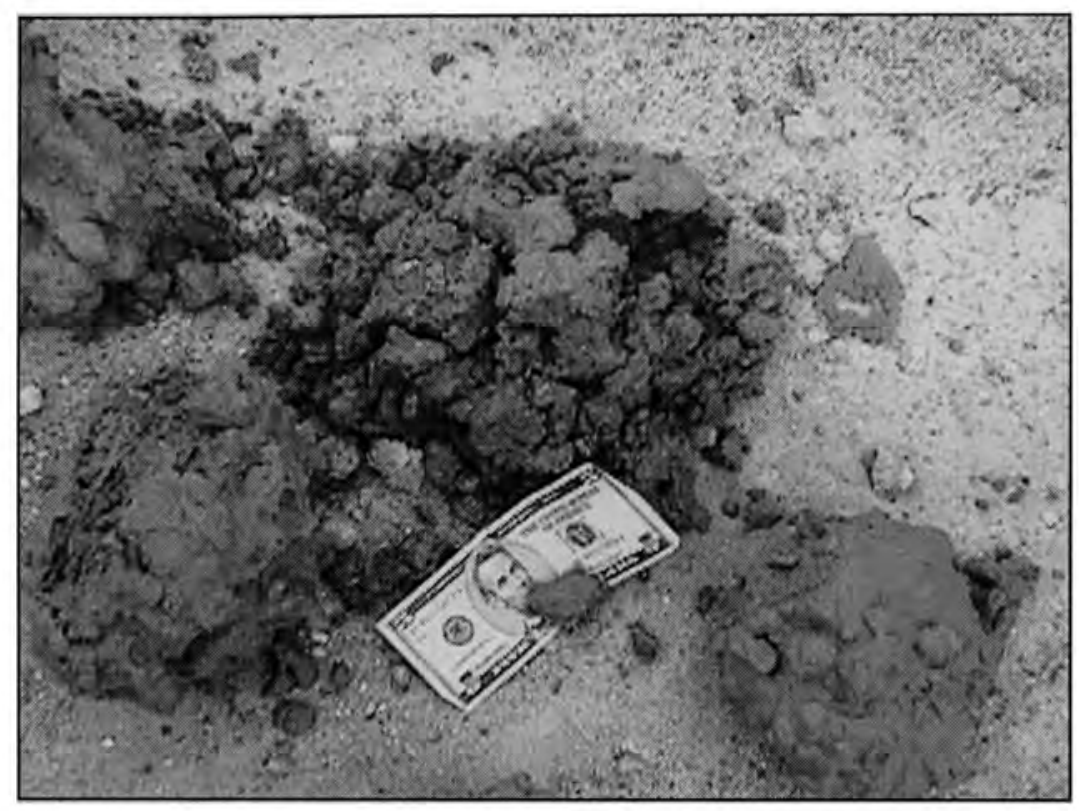

Figure 4.17 Cement Lump Composition 


\section{CHAPTER 5: DISCUSSION AND CONCLUSIONS}

\subsection{DISCUSSION}

Trials $\mathrm{A}, \mathrm{B}$, and $\mathrm{C}$ gave some insight to the problem at hand, but fell short of determining definite recommendations for a lumps-free batch. Trail A seem to provide an optimum discharge rate of $200 \mathrm{lb} / \mathrm{sec}$. Trial B tested load sizes of 3, 5, 7, and 9 cubic yards and showed an expected reduction of cement lumps with a decrease of load size. This proved to be impractical for daily FDOT and Rinker work that usually batch 9 cubic yard loads. Finally, trial $\mathrm{C}$ results appear to illustrate a reduction of cement lumps by decreasing the headwater content in the mixing procedure. (Note: truck mixer drums were not dry before tests were initiated, and the exact amount of water in the drum at that time was unknown). Furthermore, a trend of reduction of cement lumps was achieved, when additional drum revolutions are performed. The test appeared to show a correlation between a high number of initial revolutions and lower headwater content, to fewer cement lumps in the mix. A lack of information of initial revolution, total revolutions, and precise water additions prevented further conclusions on the homogeneity problem.

Trials $\mathrm{D}$ and $\mathrm{E}$ were therefore performed. These test further investigated the headwater, initial revolutions, and the total revolutions. Any water addition and mixer revolutions were carefully performed. Trial D maintained the initial revolutions at 55 and had variations on the headwater ratios. This provided an optimum value of the headwater 
ratio of $30 \%$. When a $20 \%$ headwater ratio was tested the head of the truck mixer closely resembled a head-pack therefore the headwater was increased to $30 \%$ as an optimum value. Using the optimum value attained in trial $\mathrm{D}$ of $30 \%$ headwater ratio, the initial revolutions before the slump water adjustments were tested. Test showed no cement lumps developed with 100 initial revolutions at 12 revolutions per minute.

\subsection{CONCLUSIONS}

Preliminary tests on the high-slump concrete mix design used in this research appear to demonstrate that by using a discharge rate of $200 \mathrm{lb} / \mathrm{sec}$, (a load sequence described in Chapter Three, for a standard 9 cubic yards load), reducing headwater percentage to $30 \%$, and increasing the initial revolutions to 100 revolutions for a total of 130 revolutions seems to virtually eliminate cement lumps in the high-slump concrete used for this research. Chapter 4 describes another possible link between a high headwater ratio and low initial revolutions, which also might reduce the number of cement lumps in the concrete batch. But this link cannot be completely relied upon because phase I headwater and revolution results (which appear to demonstrated this link) were inconclusive. The mixing revolutions of the batches were not a primary concern in Phase I. Therefore, the results considered as conclusive are the low headwater ratio and high initial mixing revolutions of Phase II. Moreover, Phase II results produced less and smaller size cement lumps. 
The grading samples give the impression that most of the lumps were similar in composition. The graded samples of cement lumps seem to be mainly made up of small coarse aggregates, coarse sand and cement (detailed proportions can be appreciated in Figures 4.14 and 4.15). No link between the cement lumps and their composition was found.

The suggested batching procedure might affect cost in different ways. The manufacturer must implement quality control by retraining personnel to supervise the new batching procedure. This requires personnel familiar with the suggested batching procedure; and since the new suggested values for charging the truck mixer are controlled by a batching computer, the staff of the concrete producer needs to become familiar with the program to input the necessary values when batching high-slump concrete. Nevertheless, the increase cost will probably be noticed mainly when the re-training of staff occurs. The suggestions determined by this research are not completely different from previous procedures used before. Moreover, if a lumps-free concrete can be consistently delivered to the customer, no losses of time and materials will take place. If no batches are returned the savings provided can outweigh any preliminary staff retraining costs seen by the manufacturer. Finally, if concrete manufacturers can provide a lumps-free high-slump concrete the concrete purchaser may also save time and money. By receiving a usable product (high-slump concrete), construction delays would be reduced and subsequently cost created by these delays might not increase. In the case of a 
State funded organization like FDOT, the savings would be passed to the taxpayer by way of better construction and maintenance of transportation infrastructures.

\subsection{CONTRIBUTION OF RESEARCH/ IMPLEMENTATION}

This research has been successful in providing preliminary answers to the problem statement. This work explored the occurrence of cement lumps in the highslump concrete mix design used by FDOT and to determine a possible reason and remedy to the problem. The limited results seem to demonstrate that the main reason a high number of cement lumps are present in the high-slump concrete mix used by FDOT for their drilled-shaft foundations may be that the concrete was being inadequately mixed prior to any slump stand water additions. The slump stand water additions were taken from the job site allowable water was trimmed from the mix design; it varied from 3 to 8 gallons per cubic yard (Appendix E). (A two-part process is used: the concrete is initially mixed at a 2 or 3 inch slump and then the remainder of the water is added to achieve a high-slump of 8 inches). If any water addition is made before the concrete is well mixed at a 3 inch slump, this will only increase problem. To remedy this problem proper initial mixing must be performed, by using the following procedure modified with the findings

of this research a lumps free high-slump concrete might be attainable (originally described in section 2.7.3 as Attachment \#11): 
1) A 9 cuyd batch will be prepared by initially charging $30 \%$ to $40 \%$ of the batch water with all the admixtures. Both headwater and tail-water are charged by the plant.

2) Aggregates will begin charging and all the materials are charged at $200 \mathrm{lbs} / \mathrm{sec}$.

3) After initiation of aggregate charge, cementitious material will be "ribbon fed" into the aggregate stream. Discharge of cementitious material will be completed prior to the completion of the aggregate charge. Finally the tail-water is charged.

4) The truck mixer will move out from under the concrete plant and begin initial mixing of the concrete for 100 revolutions at $12 \mathrm{rpm}$.

5) Once the initial mixing is completed, the truck mixer will drive to the slump stand to receive the remainder of the water. The job site allowable water will used to increase the slump to 8 inches. The concrete is then mixed for an additional 30 revolutions at $12 \mathrm{rpm}$.

Note: A 3" grate should be used to sieve any lumps, if some are present.

\subsection{FUTURE STUDIES}

This research study has provided an initial, but incomplete guide to mix highslump concrete in a truck mixer, without the occurrence of cement lumps and balls. The research has outlined a possible solution to the problem by suggesting a mixing procedure for high-slump concrete used by FDOT in their drilled-shafts. A continuation 
of this work is imperative in order to make conclusive recommendations to the Florida Department of Transportation.

Further testing these recommendations, will one day form the basis of a Florida Department of Transportation protocol on mixing high-slump concrete.

1) More test batches need to be conducted using the optimum values attained in these tests. A minimum of fifteen test batches (requirement for mix designs are 15 to 30 for FDOT, Appendix B) of the procedure outlined in this report should indicate whether the results of this research are actually feasible and correct using the outlined mix design.

2) The effect of other variables in the mix design need to be further analyzed. This research studied one mix design, which did not take into account the possible variations of admixtures and their affect on the mix homogeneity or the water content. Furthermore, not enough testing was performed in order to find precise values for the conclusions given by this research.

3) The trimmed water for each batch varied from 3 to $8 \mathrm{gal} /$ cuyd of concrete (trimmed from the total mix design water), this water was used to increase the slump to 7 or 8 inches (Appendix E). The impact on the homogeneity of concrete by these variations was not studied. Further experimentation is necessary to determine the how the trim water impacts the ratio of water added by the batch 
plant and the water that is manually fed to create the high-slump concrete. (Final results were achieved using an $8 \mathrm{gal} /$ cuyd trim, please see results in Appendix E.)

4) The influence of computer software should be investigated. The way software is configured or programmed at the batching plant need to be addressed, to verify if a different configuration can batch a high-slump concrete directly from the batching machine, without the need for water adjustments. 


\section{REFERENCES}

American Concrete Institute (ACI) (1999), Manual of Concrete Practice, Part 1 \& 2 $(116,201,211,212,214,221,304$, and 318), Michigan: ACI.

American Standards for Testing of Materials (ASTM) (2001), Annual Book of ASTM Standards (Vol. 04.02) (C 31, 39, 136, 138, 143, 172, 173, 231, 233, 494, 618, 989, 1017, and 1064) Pennsylvania: ASTM 2001.

American Standards for Testing of Materials (ASTM) (2001), Standard Specification for Ready-Mix Concrete, C94-00 2000: ASTM

American Standards for Testing of Materials (ASTM), Special Technical Publication (1978) Significance of Tests and Properties of Concrete and Concretes-Making Materials (No. 169B), Pennsylvania: ASTM.

Crown, R. Georgia Department of Transportation. Email inquiry: 2001

Florida Department of Transportation (FDOT) (2001), Portland Cement Concrete (section 346; subsections 346-3.2, 6.2, 7.2, 7.4, \& 8), Tallahassee: Florida, (Internet Website).

Florida Department of Transportation (FDOT) (2001), Coarse Aggregates (section 901), Tallahassee: Florida, (Internet Website).

Florida Department of Transportation (FDOT) (2001), Fine Aggregates (section 902), Tallahassee: Florida, (Internet Website).

Florida Department of Transportation (FDOT) (2001), Admixture for Concrete (section 924), Tallahassee: Florida, (Internet Website).

Florida Department of Transportation (FDOT) (2001), Slag for Portland Cement Concrete (section 929), Tallahassee: Florida, (Internet Website).

Florida Department of Transportation (FDOT) (2001), "Drilled Shaft" Construction Project Administration Manual (section 9.5), Tallahassee: Florida, (Internet Website).

Florida Department of Transportation (FDOT) (2001), "Concrete Production Facilities" Concrete Production Materials Manual (section 9.2), Tallahassee: Florida, (Internet Website).

Gambhir (1989) Concrete Technology, London, Great Britain: Oxford Ltd. 
Gaynor, R. (1996) “Avoiding Uniformity Problems in Truck-Mixed Cement." Concrete Producer: 20-25.

Gaynor, R. (1975) Mixing Concrete in a Truck Mixer, National Ready Mix Concrete Association publication No. 148, Maryland: NRMA

Haught, Jerry. Drill-Shaft Meeting Discussions and Notes. November 2001.

Kenneth, M. Email inquiry via database, Dr. Concrete: 2001.

Kosmatka, S.H., and Panarese, W.C. (1994) Design and Control of Concrete Mixtures, Illinois: PCA.

Markert, Lea. Drill-Shaft Meeting Discussions and Notes. November 2001.

McCormac, J. (1997), Design of Reinforced Concrete, California: Addison-Wesley.

Neville, A.M. (1986) Properties of Concrete, Great Britain: Longman Scientific \& Technical.

Nilson, A.H. (1997) Design of Concrete Structures, Boston: McGraw-Hill.

Rose, J. (1995), “Concrete Mix Design.” Concrete Producer: 23-26

Suprenant, B.A. (1997) "Mixing Concrete in a Truck Takes Proper Procedure." Concrete Producer: 12-22

Zuhlke, D., California Department of Transportation. Email inquiry: 2001

\section{WWW References}

www.acpa.com (Concrete Materials), First accessed: 08/2001

www.cpca.com (Fundamentals of Concrete), First accessed: 12/2001

www.drconcrete.com (Concrete Inquiry), First accessed: 12/2001

www.nrmca.com (National Ready Mix Concrete Association), First accessed: 12/2000

www.worldofconcrete.com (World of concrete), First accessed: Summer 2001. 
APPENDIX A

CONCRETE INGREDIENTS 


\section{APPENDIX A: CONCRETE INGREDIENTS}

\section{A.1 CEMENT}

The simplest explanation for cement is to think of cement as an adhesive or glue paste that bonds earth to form structural members. Cement is obtained by "intimately mixing together calcareous (calcium) and argillaceous, or other silica-, alumina-, and iron oxide-bearing materials, burning them at a clinkering temperature, and grinding the resulting clinker" (McCormack, 1997). Commonly called Portland cement because its close resemblance of the color and quality to Portland limestone quarries in Dorset of England, cement is a made up of mostly aggregate and sand. Cement and water molecules bond and create a chemical reaction called hydration. Hydration causes the cement and water to form a paste that in turn bonds the aggregates and sand to create a stone like mass. The variation of size between coarse and fine aggregates as well as sand, gives the member structural integrity by filling any existing voids present in the member. Theoretically, the concrete continues to bond and hardened for up to fifty years, but concrete reaches its designed strength at twenty-eight days after casting.

Portland cements are hydraulic cements composed primarily of hydraulic calcium silicates, these silicates along with the ones mentioned previously "combine to form a type of growth on its surface that gradually spreads until it links up with the growth of other cement particles or adheres to adjacent particles. The building up results in progressive stiffening, hardening, and strength development" (Kostmatka, 1994). 


\section{A.1.2 CEMENT MANUFACTURE \& CLASSIFICATION (PCA, 1994)}

In the United States of America the more commonly used cement are Portland cement Type I, II, III, VI, \& V; (others, such as blended hydraulic cements, expansive or special cements will not be discussed). Type I or normal Portland cement, is considered general-purpose cement suitable for all uses where the special properties of other types are not required. Type II or moderate sulfate resistance Portland cement is used where precaution against moderate sulfate attack is important. For example drainage structures, where sulfate concentrations in groundwater are higher than normal. Furthermore, Type II will generate less heat at a slower rate than Type I. Type III or early strengths Portland cement provides high strengths at an early period. It is similar to Type I cement except for its particles being grounded finer, this type is used when the structure must be in use quickly or when the forms need to be removed as soon as possible. Type IV or low heat of hydration Portland cement is used where the rate and amount of heat generated from hydration must be minimized like in the case of dams, where the amount of cement used is massive. Type IV develops strength at a lower rate than other types of cement. Type V or high-sulfate resistance Portland cement is used in concrete exposed to severe sulfate action. The high-sulfate resistance is attributed to low tricalcium aluminate content.

Cement is manufactured from raw materials "consisting of limestone, cement rock, marl or oyster shells, and shale, clay, sand, or iron ore" (PCA). Stone is first 


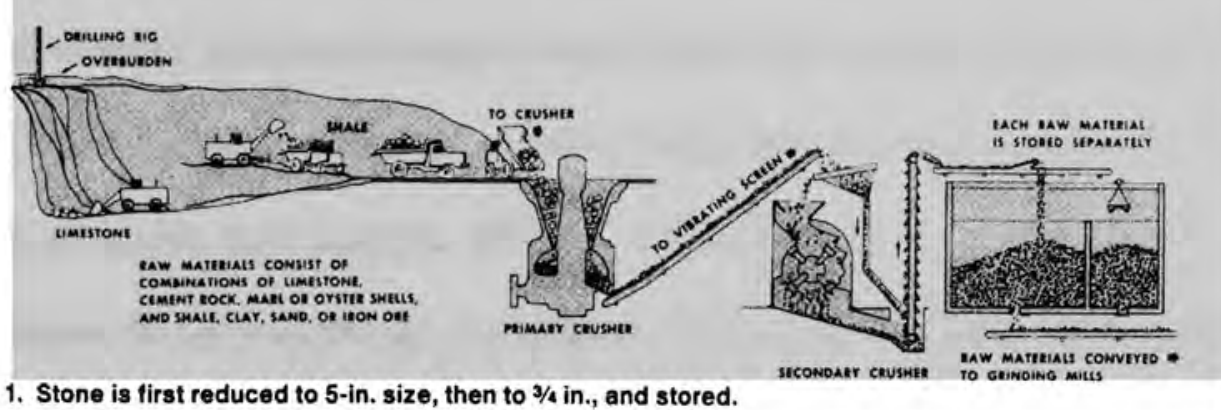

1. Stone is first reduced to 5 -in. size, then to $3 / 4$ in., and stored.

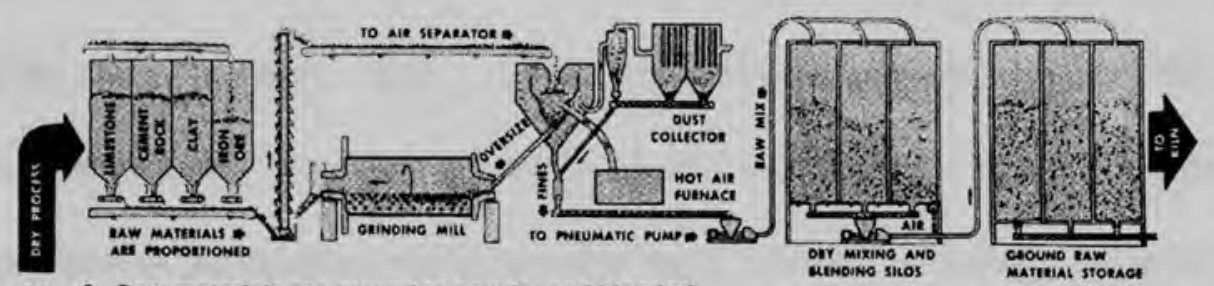

OR 2. Raw materials are ground to powder and blended.
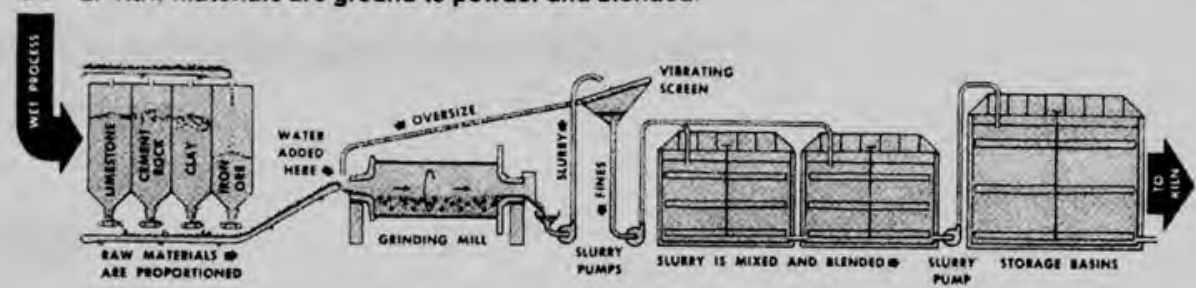

2. Raw materials are ground, mixed with water to form slurry, and blended.

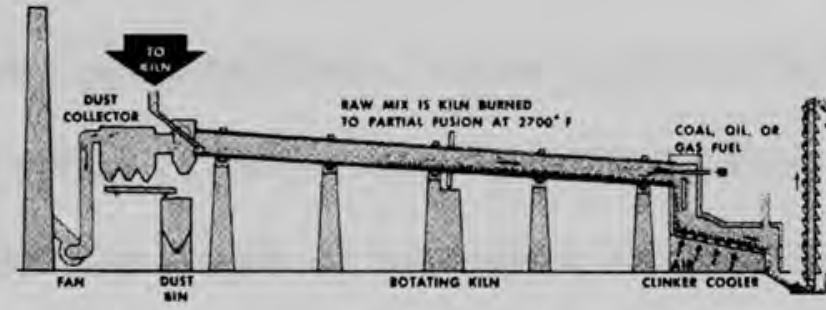

matemals ati

3. Burning changes raw mix chemically into cement clinker.
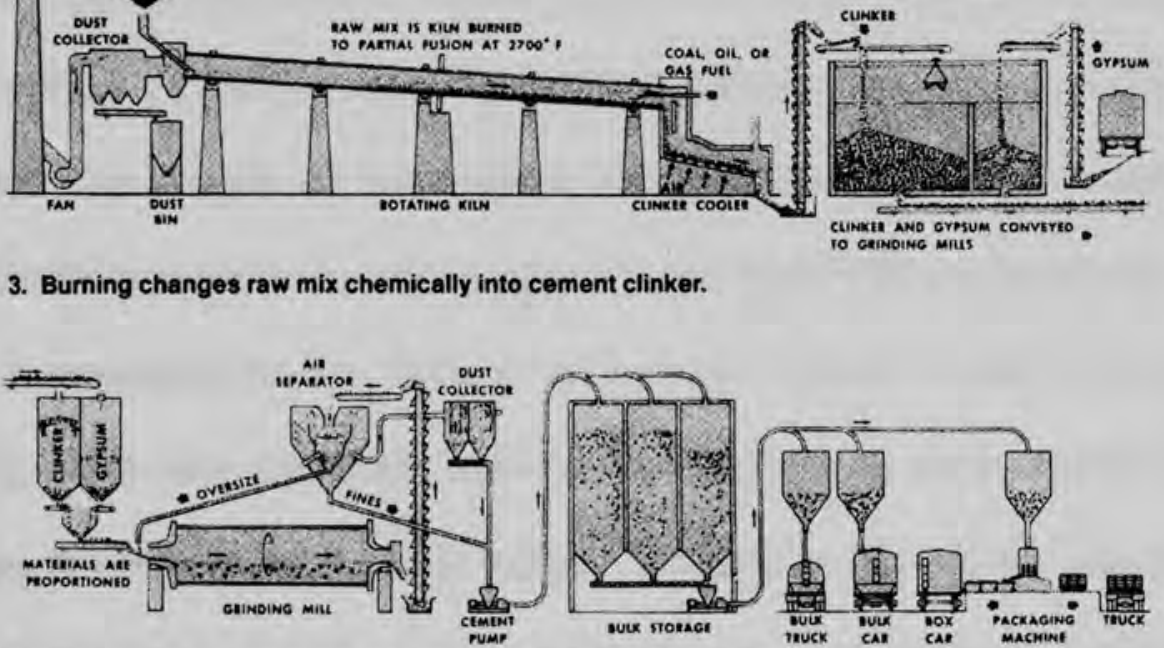

4. Clinker with gypsum is ground into portland cement and shipped.

Figure A.1 Cement Manufacturing (PCA, 1994) 
reduced to five inch and then to three quarters of an inch. Raw materials are ground to powder and blended. Burning changes the raw mixed into cement clinker in a four-stage pre-heater, flash furnace, and a shorter kiln. Finally the clinker with gypsum is ground into Portland cement and shipped. Either a dry process or a wet process is used to produce cement. In the wet process raw materials are mixed with water to form slurry and then blended, while in the dry process the raw material is mixed without the need for water. In the dry process, hot dust is created which must be collected and re-mixed in to the production process. New innovations in cement production allow the cement dust to be incorporated in pre-heaters, which provide more calcination before the cement enters the kiln. (For more details please refer to FDOT 921.)

\section{A.2 WATER}

For complete hydration of a given amount of cement an amount of water equal to about 25 percent of that of cement, by weigh or a water-cement ratio of 0.25 is needed chemically. Any amount of water above the 25 percent consumed in the chemical reaction produces pores in the cement paste. The strength of the hardened paste decreases in inverse proportion to the fraction of the total volume occupied by pores. Put differently, since only the solids, and not the voids, resist stress, strength increases directly as the fraction of the total volume occupied by the solids. That is why the strength of the cement paste depends primarily on, and decreases directly with, an increasing water-cement ratio. For normal concretes, the water-cement ratio is generally in the range of about 0.40 to 0.60 , although for high-strength concretes, ratios as low as 
0.25 have been used. When additional workability is needed to provide mobility for the water in the cement paste such as in the case of high slump concrete, the needed workability is obtained through the use of admixtures or a higher water-cement ratio.

Concrete does not need any special type of water in order to create hydration with cement. In fact, any drinking water is suitable for mixing concrete, but water that is not safe to drink could be used to batch concrete. Questionable water can be used for making concrete "if mortar cubes (ASTM 109) made with it have 7-day strength equal to at least $90 \%$ of companion specimens made with drinkable or distilled water" (Kosmatka, 1996). (For more information please see ASTM C 94 Volume 04.02 and FDOT 346-7 in Appendix B.)

\section{A.3 AGGREGATES}

In ordinary structural concretes the aggregates occupy about 70 to 75 percent of the volume of the hardened mass. The remainder consists of hardened cement paste, unmixed water, and air voids. The latter two, do not contribute to the strength of the concrete. In general, the denser the aggregate is packed, the better the strength, weather resistance, and economy of the concrete. For this reason in order to produce close packing the gradation of the particle sizes in the aggregate is of considerable importance.

It is also important that the aggregate has good strength, durability, and weather resistance. Furthermore, the surface must be free from impurities such as loam, silt, and organic matter which may weaken the bond with cement paste and that no unfavorable 
chemical reaction takes place between it and the cement. (For more information please refer ASTM C 33 and C 294 or FDOT 901 and 902.)

\section{A.4 ADMIXTURES}

In addition to the main components of concrete (aggregate, water, \& cement), admixtures are often used to improve concrete performance and can be classified by such:

1) Air-entrained admixtures

2) Water-reducing admixtures

3) Retarding admixtures

4) Accelerating admixtures

5) Super plasticizers

6) Finely divided mineral admixtures

7) Miscellaneous admixtures

There are admixtures to accelerate or retard setting and hardening, to improve workability, to increase strength, to improve durability, to lower the heat of hydration, decrease permeability, and to impart other properties. The beneficial effects of particular admixtures are well established. The major reasons for using admixtures are:

1) To reduce the cost of concrete construction

2) To achieve certain properties in concrete more effectively than by other means

3) To ensure the quality of concrete during the stages of mixing, transporting, placing, and curing in adverse conditions

4) To overcome certain emergencies during concreting operations. 
Chemical admixtures should meet the requirements of ASTM C 494 (2001), "Standard Specification for Chemical Admixtures for Concrete". Due to the great number of admixtures available for numerous mixing concerns, air-entrained and water-reducing admixtures; as well as blast-furnace slag (or fly ash) admixtures will be the discussed further. These are the admixtures incorporated in the high-slump mix design to be used in this project. (For more information on measuring admixtures please see FDOT 346-7.2 in Appendix B.)

\section{A.4.1 AIR-ENTRAINING ADMIXTURES}

Air-entraining agents are probably the most commonly used admixtures at the present time. They cause the entrainment of air in the form of microscopic-dispersed bubbles in the concrete. These improve workability and durability, and reduce segregation during placing. They decrease concrete density because of the increased void ratio and thereby decrease strength. However, this decrease can be partially offset by a reduction of mixing water without loss of workability. The chief use of air-entrained concretes is in pavements, but they are also used for structures, particularly for exposed weathered elements. (For more information please see FDOT 346-2.5.2 in Appendix B or please refer to FDOT 924-2.3.) 


\section{A.4.2 WATER-REDUCING ADMIXTURES}

Certain organic and inorganic compounds are used to reduce the water requirement of a concrete mix for a given slump. Such compounds are termed plasticizers. Reduction in water demand may result in either a reduction in the watercement ratio for a given slump and cement content, or an increase in slump for the same water-cement ratio and cement content. Plasticizers work by reducing the interparticle forces that exist between cement grains in the fresh paste, thereby increasing the paste fluidity. High-range water reducing admixtures, or superplasticizers, are used to produce high-strength concrete with a very low water-cement ratio while maintaining the higher slumps needed for proper placement and compaction of the concrete. Superplasticizers differ from conventional water-reducing admixtures in that they do not affect the surface tension of the water significantly; therefore, they can be used at higher dosages without excessive air entrainment.(For more information see FDOT 346-2.5.1 and FDOT 924-2.4 in Appendix B.)

\section{A.5 BLAST-FURNACE SLAG}

Blast-furnace slag (or fly ash) is finely divided mineral admixtures pulverized and added to concrete before or during mixing in order to enhance or change the plastic or hardened properties of concrete. Slag is classified according to its properties, see table 
A.1. (For more information please see FDOT 346-2.3 in Appendix B or please refer to ASTMC 109, C 989; ASTM tests C 188, 430, 204, and 185; and FDOT 929-2.2 \& 2.3.)

Hydraulic hydrated lime-ASTM C 141

Ground granulated iron blast-furnace slag-ASTM C 989

Grade 80

Slag with a low activity index

Grade 100

Slag with a moderate activity index

Grade 120

Slag with a high activity index

Fly ash and natural pozzolans-ASTM C 618

Class $\mathrm{N}$

Raw or calcined natural pozzolans including

Diatomaceous earths

Opaline cherts and shales

Tuffs and volcanic ashes or pumicites

Some calcined clays and shales

Class F

Fly ash with pozzolanic properties

Class C

Fly ash with pozzolanic and cementitious properties

Table A.1 Specifications and Classes of Finely Divided Mineral Admixtures

\section{A.6 SLUMP TEST}

Highly workable concrete, known as high slump concrete is usually specified to be from 7 to 9 inches. In order to be certain that the specified design slump is being used, a test known as "the slump test" is performed. This test is the most widely used, primarily because of the simplicity of the test. A project engineer at the job site usually performs 
this slump test (Figure A.2). The slump test indicates the behavior of a compacted concrete cone under the action of gravitational forces. The test is carried out with a mold called the "slump cone". The Florida Department of Transportation outlines a slump lost procedure of their own, for more details please refer to their code in appendix B.

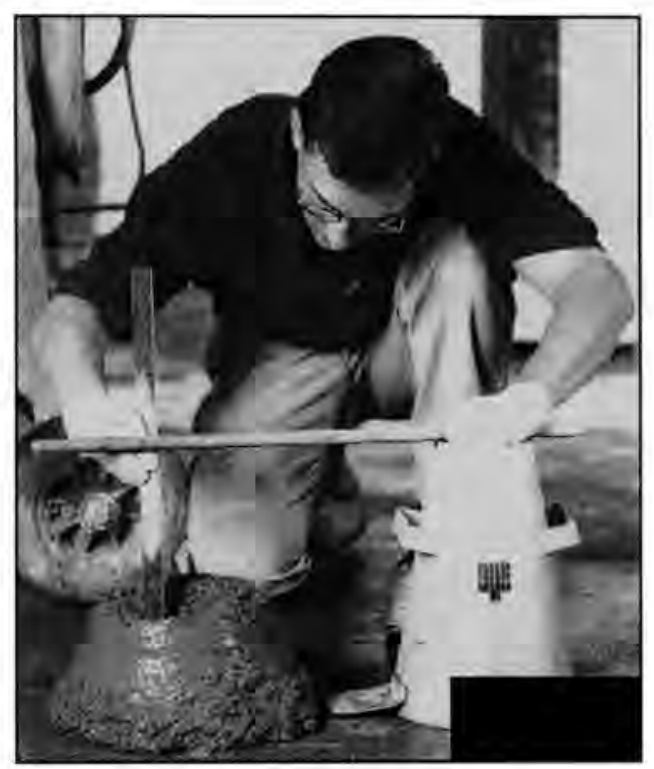

FIGURE A.2 SLUMP TEST

\section{A.7 COMPRESSIVE STRENGHT RESULTS}

Compressive strength cylinder test were performed in most batches in Phase I. As described in Chapter Three cylinder samples were collected in order to test strength requirement at 7 and 28 days. In Phase II no strength tests were performed. Compressive strength results suggest that the batch to batch uniformity of compressive strength of the 
batches in Phase I are quite good. This is reflected by the low coefficient of variation apparent in Table A.2 between $3.5 \%$ and $5.5 \%$. The concrete strength at 7 and 28 days averaged 5,783 psi and 7,177 psi respectively. The mix is designed to be a 4,000 psi mix design, but the actual strength is much larger. This is because the mix is over-design for safety concerns. The influence over-design requirements have on the mix homogeneity was not determined or studied.

Compressive Strength Tests

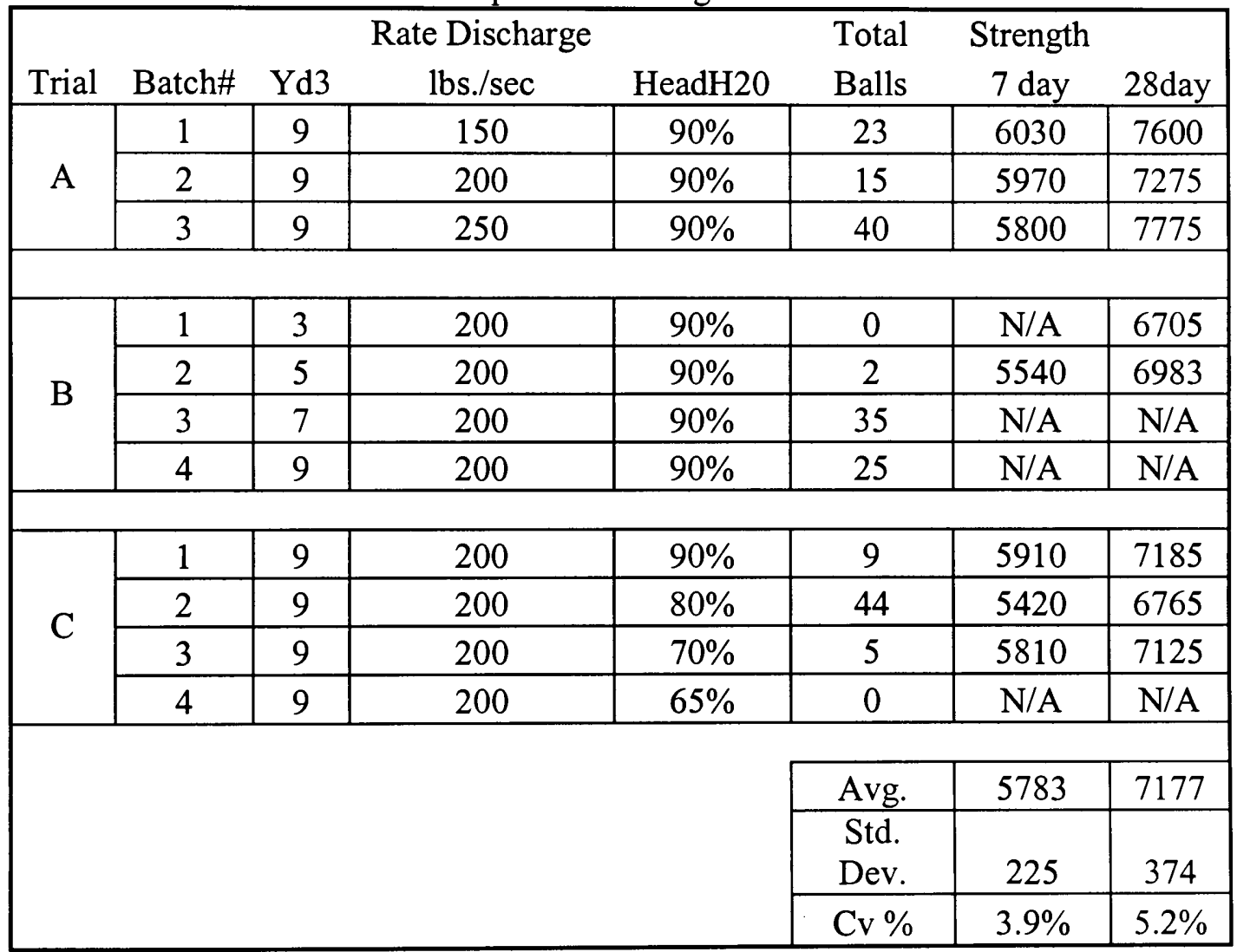

Table A.2 Compressive Strength Results 


\begin{abstract}
APPENDIX B
FLORIDA DEPARTMENT OF TRANSPORTATION

FDOT 346 STANDARD SPECIFICATIONS FOR ROAD BRIDGE CONSTRUCTION

PORTLAND CEMENT CONCRETE
\end{abstract}




\section{SECTION 346 \\ PORTLAND CEMENT CONCRETE}

\section{6-1 Description.}

Use concrete composed of a mixture of portland cement, aggregate, water, and, where specified, admixtures and pozzolan. Deliver the portland cement concrete to the site of placement in a freshly mixed, unhardened state.

Meet the production and quality control of concrete provisions of this Section and the Florida Department of Transportation Standard Operating Procedures.

\section{6-2 Materials.}

346-2.1 General: Meet the following requirements:

Coarse Aggregate Section 901

Fine Aggregate* Section 902

Portland Cement Section 921

Water Section 923

Admixtures Section 924

Fly Ash, Slag** and Microsilica (Pozzolanic Materials) Section 929

*The Engineer will allow only silica sand except as provided in 902-5.2.3.

**The Engineer will allow only granulated blast furnace slag.

Use the materials containing no hardened lumps, crusts or frozen matter, and that are not contaminated with dissimilar material.

346-2.2 Types of Cement: Unless a specific type of cement is designated elsewhere, use Type I, Type IP, Type IS, Type IP(MS), Type II, or Type III cement in all classes of concrete. Use only the types of cements designated for each environmental condition in structural concrete.

\begin{tabular}{|c|c|c|c|}
\hline \multicolumn{4}{|c|}{ TABLE 1} \\
\hline \multicolumn{4}{|c|}{ BRIDGE SUPERSTRUCTURES } \\
\hline Component & $\begin{array}{c}\text { Slightly Aggressive } \\
\text { Environment }\end{array}$ & $\begin{array}{c}\text { Moderately Aggressive } \\
\text { Environment }\end{array}$ & $\begin{array}{c}\text { Extremely Aggressive } \\
\text { Environment }\end{array}$ \\
\hline $\begin{array}{l}\text { Precast Superstructure } \\
\text { and Prestressed }\end{array}$ & $\begin{array}{l}\text { Type I, Type II, Type } \\
\text { III, Type IP, Type IS, or } \\
\text { Type IP (MS) }\end{array}$ & $\begin{array}{l}\text { Type I, Type II, and } \\
\text { Type III all with Fly } \\
\text { Ash or Slag; Type IP, }\end{array}$ & $\begin{array}{l}\text { Type II with Fly Ash or } \\
\text { Type II with Slag }\end{array}$ \\
\hline
\end{tabular}




\begin{tabular}{|c|c|c|c|}
\hline \multicolumn{4}{|c|}{ TABLE 1} \\
\hline \multicolumn{4}{|c|}{ BRIDGE SUPERSTRUCTURES } \\
\hline Elements & & $\begin{array}{c}\text { Type IS, or Type } \\
\text { IP(MS) }\end{array}$ & \\
\hline $\begin{array}{l}\text { C.I.P. Superstructure } \\
\text { Slabs and Barriers }\end{array}$ & $\begin{array}{l}\text { Type I, Type II, Type } \\
\text { IP, Type IS, or Type } \\
\text { IP(MS) }\end{array}$ & $\begin{array}{l}\text { Type I with Fly Ash or } \\
\text { Slag, Type II, Type IP, } \\
\text { Type IS, or Type } \\
\text { IP(MS) }\end{array}$ & $\begin{array}{c}\text { Type II with Fly Ash or } \\
\text { Type II with Slag }\end{array}$ \\
\hline \multicolumn{4}{|c|}{ BRIDGE SUBSTRUCTURE, DRAINAGE STRUCTURES AND OTHER STRUCTURES } \\
\hline Component & $\begin{array}{c}\text { Slightly Aggressive } \\
\text { Environment }\end{array}$ & $\begin{array}{c}\text { Moderately Aggressive } \\
\text { Environment }\end{array}$ & $\begin{array}{c}\text { Extremely Aggressive } \\
\text { Environment }\end{array}$ \\
\hline $\begin{array}{l}\text { All Structure } \\
\text { Components }\end{array}$ & $\begin{array}{c}\text { Type I, Type II, Type } \\
\text { III, Type IP, Type IS, or } \\
\text { Type IP (MS) }\end{array}$ & $\begin{array}{l}\text { Type I with Fly Ash or } \\
\text { Slag, Type II, Type IP, } \\
\text { Type IP(MS), or Type } \\
\text { IS }\end{array}$ & $\begin{array}{l}\text { Type II with Fly Ash or } \\
\text { Type II with Slag }\end{array}$ \\
\hline
\end{tabular}

346-2.3 Use of Fly Ash, Slag, Microsilica, and Other Pozzolanic Materials: The Contractor may use fly ash, slag, microsilica and other pozzolanic materials as a cement replacement in all classes of concrete (when Type I, Type II, or Type III cement is used) with the following limitations:

(1) When fly ash, slag or microsilica is used as a cement replacement, use it on a pound per pound [kilogram per kilogram] basis. Calculate cement replacement as shown in the example. Example - Assume a total cementitious content of 752 pounds $[341 \mathrm{~kg}$ ]. Calculate the required microsilica for a $7.6 \%$ replacement as 752 by $.076=57$ pounds [ 341 by $.076=26 \mathrm{~kg}$ ]. Calculate the required fly ash for a $20 \%$ replacement as 752 by $0.20=151$ pounds [ 341 by $0.20=68 \mathrm{~kg}$ ]. Cement required is 544 pounds [247 kg].

(2) Ensure that the quantity of cementitious material replaced with fly ash in mass concrete is greater than $18 \%$ and less than $50 \%$ by weight of the total cementitious content. The minimum cementitious content for each class of concrete is shown in the Master Proportion Table (Table 3). 
(3) Ensure that the quantity of cementitious material replaced with fly ash in drilled shaft concrete is $35 \pm 2 \%$ by weight of the total cementitious content.

(4) For all other concrete uses not covered in (2) and (3) above, ensure that the quantity of cementitious material replaced with fly ash is greater than $18 \%$ and less than $22 \%$ by weight of the total cementitious content.

(5) Ensure that the pozzolan constituent of Type IP(MS) is in the range of 15 to $40 \%$ by weight of the portland-pozzolan cementitious material.

(6) Obtain the Engineer's approval to use pozzolanic materials other than Class F fly ash.

(7) Ensure that the quantity of cementitious material replaced with slag in drilled shaft concrete is $60 \pm 2 \%$ by weight of the total cementitious content.

(8) For all other concrete uses not covered in (7) above, ensure that the quantity of cementitious material replaced with slag is not less than $25 \%$ or greater than $70 \%$ of the total cementitious content when used in Slightly and Moderately Aggressive environments, and not less than $50 \%$ or greater than $70 \%$ of the total cementitious content when used in Extremely Aggressive environments. When used in combination with microsilica, ensure that the slag does not replace less than $50 \%$ or more than $55 \%$ of the total cementitious content.

(9) Ensure that the quantity of cementitious material replaced with microsilica is not less than $7 \%$ or greater than $9 \%$. Use high range water reducing admixtures in concrete mixes incorporating microsilica.

346-2.4 Coarse Aggregate Gradation: Produce all concrete using Size No. 57 or Size No. 67 coarse aggregate except as follows:

(1) With the Engineer's approval, the Contractor may use Size No. 8 or Size No. 89 either alone or blended with Size No. 57 or Size No. 67 for concrete construction that is heavily reinforced or for barrier wall or curb construction using slip forms.

(2) The Engineer may approve other gradations of aggregates. The Engineer will consider requests for approval of other gradations individually and will require the Contractor to submit sufficient statistical data to establish production quality and uniformity of the subject aggregates, and to establish the quality and uniformity of the resultant concrete. Furnish aggregate gradations sized larger than nominal maximum size of 1.5 inch [37.5 mm] as two components.

(3) Select the maximum coarse aggregate size so as not to violate the reinforcement spacing provisions given for reinforced concrete in the AASHTO Standard Specifications for Highway Bridges. 


\section{6-2.5 Admixture Requirements:}

346-2.5.1 Chemical Admixtures: Use concrete containing a water-reducing admixture (Type A) or water-reducing and retarding admixture (Type D). Use a dosage rate that is generally in accordance with the manufacturer's recommended dosage rate. When necessary, adjust the dosage rate.

The Engineer may approve the use of other admixtures. The Engineer will require the Contractor to submit statistical evidence supporting successful laboratory and field trial mixes which demonstrate improved concrete quality or handling characteristics.

The Engineer will not allow chemical admixtures or additives containing calcium chloride (either in the raw materials or introduced during the manufacturing process) in reinforced concrete.

346-2.5.2 Air Entrainment Admixtures: Ensure that all concrete except counterweight concrete contains an air entraining admixture. Establish dosage rates by trial mixes, and adjust them to meet field conditions.

346-2.5.3 High Range Water Reducing Admixtures: Use high range water reducing admixtures in concrete mixes incorporating microsilica. The Contractor may propose the use of an approved High Range Water Reducer (HRWR) admixture, either Type F or Type G. In a proposal to use HRWR for precast items, include a list of precast items for which it is proposed. The Contractor may also propose the use of HRWR for cast-in-place concrete, except for concrete used in drilled shafts. In a proposal to use HRWR for cast-in-place items, include a detailed listing of the areas, locations, elements, etc. for which its use is proposed and the anticipated benefits to be derived from the use of HRWR in each instance.

Perform all testing for plastic concrete properties after the HRWR has been added to the concrete mix.

The Department will not consider Value Engineering credits or other price adjustments for proposals to utilize HRWR in order to reduce the specified minimum cementitious requirements for the various classes of concrete.

In a proposal to use HRWR in concrete, include the following:

A certification from the HRWR supplier that the HRWR admixture proposed meets the requirements of ASTM C 494, Type F or G. Ensure that the certificate states that the one year tests representing the admixture to be supplied have been performed by an independent laboratory approved by the Cement and Concrete Reference Laboratory (CCRL) and that the records of such tests will be furnished to the Department on request. Ensure that the certification also includes an 
additional statement from the HRWR supplier or an approved independent testing laboratory that the proposed HRWR admixture is compatible with all other admixtures to be included in the concrete design mix.

When a HRWR admixture is proposed for use in the design mix, propose a target slump value. Ensure that the target slump does not exceed 7 inches [180 mm]. Meet the other control requirements and ranges as specified herein.

Include with the confirming data all details of the design mix ingredients, all required certificates from the supplier and independent testing laboratory, and a certificate from the Witnessing Department Engineer. Ensure that the certificate states that the Contractor has demonstrated through production and placement of the required number of batches that concrete containing HRWR has been produced meeting all test requirements, that the HRWR concrete has been satisfactorily mixed in accordance with the Contractor's proposed methods and sequences, and that the concrete was acceptably placed, consolidated and cured.

Before the Engineer approves any design mix, demonstrate through production of at least three batches $\left(3 \mathrm{yd}^{3}\left[2.3 \mathrm{~m}^{3}\right]\right.$ minimum size each) of concrete containing the HRWR that the concrete plant can produce concrete consistently meeting specified slump, air content, and compressive strength requirements. Also demonstrate to the Witnessing Department Engineer that the concrete containing the HRWR admixture in accordance with the proposed design mixes can be placed, consolidated and finished under conditions existing for the proposed uses. Obtain the Engineer's approval before using HRWR concrete design mixes.

The Engineer may approve proposed HRWR mixes for concrete, centrally mixed at the placement site, without the production of demonstration batches providing you meet the requirements of 346-6.2, and:

(1) A previously approved HRWR mix of the same class has demonstrated satisfactory performance under the proposed job placing conditions with a minimum of 15 consecutive Department acceptance tests which met all plastic and hardened concrete test requirements.

(2) The cement and water reducing admixtures used in the proposed mix are the same materials from the same source used in the previously approved mix (Item (1) above), and the other materials and mix proportions are approved as similar by the Engineer.

Dispose of concrete produced for demonstration purposes at no expense to the Department. Subject to the Engineer's approval, the Contractor may incorporate this concrete into unreinforced concrete items. 
Include with each design mix a description of methods, sequences, times and places that the HRWR will be introduced into the concrete mix for each proposed use. Adjust methods, sequences, times and places for introduction of the HRWR to suit the requirements for each proposed use and condition. The Contractor may transfer design mixes including a HRWR based on demonstrated ability of the mix to perform its intended function.

The Engineer will consider design mixes submitted for approval upon receiving certification from the Witnessing Department Engineer that the Contractor has demonstrated the ability to produce concrete containing a HRWR admixture in accordance with the proposed design mixes, meeting minimum strength requirements within specified ranges for slump and air, and which can be placed, consolidated and finished under conditions existing for the proposed uses. In addition, the Witnessing Department Engineer will include in the certification the test values of the slump, air and 28-day strength tests for all demonstration batches of concrete, and an evaluation and description of the Contractor's actual sequences, methods and time required for the placement and consolidation of each batch of concrete. Also include in the certification, the Witnessing Department Engineer's evaluation of the appearance, apparent consolidation and finish texture after form removal of each item cast.

Except for casting unreinforced concrete items as approved by the Engineer, do not produce or place demonstration concrete containing a HRWR admixture for payment under Contract pay items until design mixes containing the HRWR have been approved. To qualify for payment under Contract pay items, ensure that unreinforced demonstration concrete, cast with the approval of the Engineer, meets minimum strength and entrained air requirements contained in these Specifications, and that the slump is within 1.5 inch [ $40 \mathrm{~mm}$ ] of the target slump proposed by the Contractor.

346-2.5.4 Corrosion Inhibitor Admixture: Ensure that concrete containing a corrosion inhibitor admixture also contains cementitious materials consisting of Type II cement and Class F fly ash. The Contractor may use ground granulated blast furnace slag in lieu of fly ash.

Ensure that concrete containing a corrosion inhibitor admixture also contains a water reducing retardant admixture (Type $\mathrm{D}$ ). The Contractor may also need to use a high range water reducer Type $\mathrm{F}$ (or Type $\mathrm{G}$ ) to provide the required workability and to normalize the setting time of concrete. Ensure that all admixtures are compatible with the corrosion inhibitor admixture.

346-2.6 Mixing Different Coarse Aggregates: The Engineer may allow the substitution of coarse aggregate of the same type from a different source in an approved concrete mix when the aggregate to be substituted is also from an approved source and has similar physical and 
chemical properties. If unsatisfactory results are obtained with the different source aggregate, return to the aggregate from the originally approved aggregate source of supply.

\section{6-3 Classification, Strength, Slump, and Air Content.}

346-3.1 General: The separate classifications of concrete covered by this Section are designated as Class I, Class II, Class III, Class IV, Class V, and Class VI. Strength, slump, and air content of each class are specified in the following (Table 2):

\begin{tabular}{|c|c|c|c|}
\hline \multicolumn{4}{|c|}{ TABLE 2} \\
\hline Class of Concrete & $\begin{array}{c}\text { Specified Minimum } \\
\text { Strength (28-day) (psi) } \\
{[(\mathrm{MPa})]}\end{array}$ & $\begin{array}{c}\text { Target Slump } \\
\text { (inches) }[(\mathrm{mm})](\mathrm{d})\end{array}$ & $\begin{array}{l}\text { Air Content } \\
\text { Range (\%) }\end{array}$ \\
\hline \multicolumn{4}{|c|}{ STRUCTURAL CONCRETE } \\
\hline I (Pavement) (b) & $3,000[21]$ & $2[50]$ & 1 to 6 \\
\hline I (Special) (a) & $3,000[21]$ & $3[75]$ & 1 to 6 \\
\hline II (a) & $3,400[23]$ & $3[75](c)$ & 1 to 6 \\
\hline II (Bridge Deck) & $4,500[31]$ & $3[75](c)$ & 1 to 6 \\
\hline III & $5,000[35]$ & $3[75](c)$ & 1 to 6 \\
\hline III (Seal) & $3,000[21]$ & $8[200]$ & 1 to 6 \\
\hline IV & $5,500[38]$ & $3[75](c)$ & 1 to 6 \\
\hline IV (Drilled Shaft) & $4,000[28]$ & $8[200]$ & 0 to 6 \\
\hline V (Special) & $6,000[41]$ & $3[75](\mathrm{c})(\mathrm{e})$ & 1 to 5 \\
\hline $\mathrm{V}$ & $6,500[45]$ & $3[75](\mathrm{c})$ & 1 to 5 \\
\hline $\mathrm{VI}$ & $8,500[59]$ & $3[75](c)$ & 1 to 5 \\
\hline
\end{tabular}

(a) The Contractor may use concrete meeting the requirements of ASTM C 478 $(4,000 \mathrm{psi})$ [ASTM C $478 \mathrm{M}(30 \mathrm{MPa})$ ] in lieu of Class I or Class II concrete in precast items manufactured in plants which meet the Department's Standard Operating Procedures for Precast Drainage products. Apply the chloride content limits specified in 346-4.2 to all precast or cast-inplace box culverts. 
(b) Ensure that consistency of the concrete is such that the edges of the pavement surface consistently meet the surface requirements in Section 350 .

(c) The Engineer may allow higher target slump, not to exceed 7 inches [180 $\mathrm{mm}]$, when a high range water reducer is used.

(d) The Engineer may approve a reduction in the target slump for slipformed or prestressed elements.

(e) When the use of microsilica is required as a pozzolan in Class V (Special) concrete, ensure that the concrete does not exceed a permeability of 1,000 coulombs at 28-days when tested per AASHTO T 277. Submit 2, 4-inch [102 mm] diameter by 8 inch [203 mm] length cylindrical test specimens to the Engineer for permeability testing prior to mix design approval. The permeability of the concrete will be taken as the average of two tests. The Engineer may require permeability tests during production.

346-3.2 Drilled Shaft Concrete: When drilled shaft concrete is specified or required in the Contract Documents and is to be placed in any wet shaft, provide concrete in accordance with the following specified slump loss requirements. When concrete is placed in a dry excavation, do not test for slump loss, except where a temporary removable casing is required.

Ensure that drilled shaft concrete has a slump between 7 inches and 9 inches $[180 \mathrm{~mm}$ and $230 \mathrm{~mm}$ ] when placed and maintains a slump of 4 inches $[100 \mathrm{~mm}$ ] or more throughout the drilled shaft concrete elapsed time. Ensure that the slump loss is gradual as evidenced by slump loss tests described below. The concrete elapsed time is the sum of the mixing and transit time, the placement time and the time required for removal of any temporary casing that causes or could cause the concrete to flow into the space previously occupied by the temporary casing.

Provide slump loss tests before drilled shaft concrete operations begin, demonstrating that the drilled shaft concrete maintains a slump of at least 4 inches $[100 \mathrm{~mm}]$ throughout the concrete elapsed time. Inform the Engineer at least 48 hours prior to performing such tests in order to allow arrangements to be made for a Department representative to witness the mixing and testing required. Perform slump loss testing of the drilled shaft mix using a laboratory acceptable to the Engineer. Use a laboratory that (1) has been inspected by the CCRL on a regular basis, with all deficiencies corrected, and under the supervision of a Specialty Engineer, or (2) meets all the requirements of ASTM C 1077.

Perform the following procedures for slump loss tests:

(1) Perform a test for time of setting of concrete mixtures by penetration resistance (FM 1-T 197). 
(2) Prepare the mix for the slump loss test at a temperature consistent with the highest ambient and concrete temperatures expected during actual concrete placement. Obtain the Engineer's approval of the test temperature.

(3) Ensure that the mix is at least $3 \mathrm{yd}^{3}\left[2.3 \mathrm{~m}^{3}\right]$ and is mixed in a mixer truck.

(4) After initial mixing, determine the slump, concrete temperature, ambient temperature and air content. Ensure that the concrete properties are within the required specification limits. Initiate the time of setting test (FM 1-T 197) at this time.

(5) Mix the concrete intermittently for 30 seconds every five minutes at the mixing speed of the mixer.

(6) Determine slump, concrete temperature, ambient temperature and air content at 30 minute intervals until the slump is 2 inches [50 mm] or less. Remix the mix for one minute at the mixing speed of the mixer before these tests are run.

(7) Begin all elapsed times when water is initially introduced into the mix.

(8) Ensure that the concrete maintains a slump of at least 4 inches $[100 \mathrm{~mm}]$ for the anticipated elapsed time.

(9) Obtain the Engineer's approval of slump loss test results in terms of elapsed time prior to concrete placements.

346-3.3 Mass Concrete: When mass concrete is designated in the Contract Documents, provide an analysis of the anticipated thermal developments in the mass concrete elements for all expected project temperature ranges using the proposed mix design, casting procedures, and materials. Additionally, describe the measures and procedures intended for use to maintain a temperature differential of $35^{\circ} \mathrm{F}\left[20^{\circ} \mathrm{C}\right]$ or less between the interior and exterior portions of the designated mass concrete elements during curing. Submit both the mass concrete mix design and the proposed plan to monitor and control the temperature differential concurrently to the Engineer for approval a minimum of ten working days prior to concrete placement. Provide temperature monitoring devices approved by the Engineer to record temperature development between the interior and exterior portions of the elements at points approved by the Engineer. Read the monitoring devices and record the readings at not greater than 6-hour intervals, as approved by the Engineer, beginning when casting is complete and continuing until the maximum temperature differential is reached and begins dropping. If monitoring indicates the $35^{\circ} \mathrm{F}\left[20^{\circ} \mathrm{C}\right]$ differential has been exceeded, take immediate action to retard further growth in the temperature differential and make the necessary revisions to the approved plan to maintain the $35^{\circ} \mathrm{F}\left[20^{\circ} \mathrm{C}\right]$ or less differential on any remaining placements. Obtain the Engineer's approval of revisions to the 
approved plan prior to implementation.

\section{6-4 Composition of Concrete.}

346-4.1 Master Proportion Table: Proportion the materials used to produce the various classes of concrete in accordance with the following (Table 3):

\begin{tabular}{|c|c|c|}
\hline & TABLE 3 & \\
\hline Class of Concrete & $\begin{array}{c}\text { Minimum Total Cementitious } \\
\text { Content } \mathrm{lb} / \mathrm{yd}^{3}\left[\mathrm{~kg} / \mathrm{m}^{3}\right]\end{array}$ & $\begin{array}{c}\text { *Maximum Water Cement } \\
\text { Ratio lb/lb }[\mathrm{kg} / \mathrm{kg}]\end{array}$ \\
\hline I (Pavement) & $508[300]$ & 0.50 \\
\hline I (Special) & $508[300]$ & 0.50 \\
\hline II & $564[335]$ & 0.49 \\
\hline II (Bridge Deck) & $611[365]$ & 0.44 \\
\hline III & $611[365]$ & 0.44 \\
\hline III (Seal) & $611[365]$ & 0.41 \\
\hline IV & $658[390]$ & 0.41 \\
\hline IV (Drilled Shaft) & $658[390]$ & $0.37^{* *}$ \\
\hline V (Special) & $752[445]$ & $0.37^{* *}$ \\
\hline V & $752[445]$ & 0.37 \\
\hline VI & $752[445]$ & 0.52 \\
\hline
\end{tabular}

*The Engineer will calculate water cement ratio $(\mathrm{W} / \mathrm{C})$ based on the total cementitious material including microsilica, fly ash or slag.

**When the use of microsilica is required as a pozzolan, the Engineer will approve mix designs at a maximum water cement ratio of 0.35 .

\section{6-4.2 Chloride Content Limits for Concrete Construction:}

346-4.2.1 General: Use the following maximum chloride content limits for the concrete application shown: 


\begin{tabular}{|c|c|c|}
\hline \multirow[b]{2}{*}{ Application } & \multicolumn{2}{|c|}{$\begin{array}{l}\text { Maximum Allowable } \\
\text { Chloride Content } \mathrm{lb} / \mathrm{yd}^{3}\left[\mathrm{~kg} / \mathrm{m}^{3}\right]\end{array}$} \\
\hline & Production & Mix Design \\
\hline Non Reinforced Concrete & N/A & N/A \\
\hline $\begin{array}{l}\text { Reinforced Concrete that does not require Type II } \\
\text { cement plus slag or pozzolan(s) }\end{array}$ & $0.70[0.42]$ & $0.64[0.38]$ \\
\hline $\begin{array}{l}\text { All applications that require Type II cement plus } \\
\qquad \operatorname{pozzolan(s)}\end{array}$ & $0.40[0.24]$ & $0.34[0.20]$ \\
\hline Prestressed Concrete & $0.40[0.24]$ & $0.34[0.20]$ \\
\hline
\end{tabular}

Determine the chloride content as the average of three tests on samples taken from the concrete. Ensure that the range of results of the three tests does not exceed a chloride content of $0.08 \mathrm{lb} / \mathrm{yd}^{3}\left[0.05 \mathrm{~kg} / \mathrm{m}^{3}\right]$ of concrete. When test results are outside of the allowable range, run an additional three tests until the test results are within the allowable range. The Contractor may obtain samples from representative concrete cylinders or cores tested for compressive strength. If the cylinders or cores have been exposed to salt or aggressive environment, discard the outer 1 inch [25 $\mathrm{mm}$ ] surface of the sample.

346-4.2.2 Sampling and Testing: Determine chloride content in accordance with FM 5-516.

(1) For all concrete requiring Type II cement with pozzolan(s) or slag and prestressed concrete, determine the chloride content on a frequency that is in accordance with these Specifications and the following procedures:

(a) When the chloride content is $0.25 \mathrm{lb} / \mathrm{yd}^{3}\left[0.15 \mathrm{~kg} / \mathrm{m}^{3}\right]$ or less, make subsequent tests on a frequency of not less than one for every four weeks of production as long as the test results remain at or below $0.25 \mathrm{lb} / \mathrm{yd}^{3}\left[0.15 \mathrm{~kg} / \mathrm{m}^{3}\right]$. As an exception to the aforementioned testing frequency, when eight consecutive tests show chloride content below $0.25 \mathrm{lb} / \mathrm{yd}^{3}\left[0.15 \mathrm{~kg} / \mathrm{m}^{3}\right]$, the Engineer may reduce the frequency of testing.

(b) When the chloride content is greater than 0.25 [0.15] and less than or equal to $0.33 \mathrm{lb} / \mathrm{yd}^{3}\left[0.20 \mathrm{~kg} / \mathrm{m}^{3}\right]$, make subsequent tests at a frequency of not less than one for every two weeks of production, as long as the values remain at or below $0.33 \mathrm{lb} / \mathrm{yd}^{3}$ $\left[0.20 \mathrm{~kg} / \mathrm{m}^{3}\right]$.

(c) When the chloride content is greater than $0.33 \mathrm{lb} / \mathrm{yd}^{3}\left[0.20 \mathrm{~kg} / \mathrm{m}^{3}\right]$, make subsequent chloride content tests for each day's production. 
(2) For all reinforced concrete other than concrete requiring Type II cement with slag or pozzolan(s) and prestressed concrete, determine the chloride content on a frequency of not less than one test every four weeks. As an exception to the aforementioned testing frequency, when eight consecutive chloride content determinations are below $0.40 \mathrm{lb} / \mathrm{yd}^{3}$ $\left[0.24 \mathrm{~kg} / \mathrm{m}^{3}\right]$ of concrete, the Engineer may reduce the frequency of testing.

For any case listed above, when the source of any concrete component material, including admixtures, is changed, determine the chloride content immediately.

Test results obtained at the frequency provided above represent the chloride content of all concrete placed subsequent to the preceding test for the determination of chloride content.

346-4.2.3 Certification: Determine the chloride content, and certify the test results of chloride determinations to the Department. Include in the certification all pertinent data required by the Department. The Department will require properly executed certifications showing the chloride content within the required limits for acceptance of all concrete produced in accordance with these Specifications.

346-4.2.4 Control Level for Corrective Action: If the test results indicate that the chloride level is greater than the following limits, suspend concrete production until implementing corrective measures.

(1) Chloride content of $0.65 \mathrm{lb} / \mathrm{yd}^{3}\left[0.39 \mathrm{~kg} / \mathrm{m}^{3}\right]$ or greater for reinforced concrete that does not require Type II cement plus slag or pozzolan(s).

(2) Chloride content of $0.35 \mathrm{lb} / \mathrm{yd}^{3}\left[0.21 \mathrm{~kg} / \mathrm{m}^{3}\right]$ or greater for prestressed concrete and all applications that require Type II cement with slag or pozzolan(s).

The Engineer will reject the concrete exceeding the maximum allowable chloride content limits shown in 346-4.2.1, if an analysis by the Department indicates an unacceptable loss of concrete durability considering the environmental classification of the site.

\section{6-5 Sampling and Testing Methods.}

Perform concrete sampling and testing in accordance with the following standard Florida Test Methods: 


\begin{tabular}{|l|l|}
\hline Description & Method \\
\hline Slump & FM 1-T 119 \\
\hline Air Content* & FM 1-T 152 \\
\hline Pressure Type meter & FM 1-T 196 \\
\hline Volumetric Type meter & FM 1-T 199 \\
\hline Chace & FM 1-T 023 \\
\hline Making and Curing Test Cylinders** & FM 1-T 022 \\
\hline Testing Cylinders** & FM 1-T 024 \\
\hline Taking and Testing Drilled Core Samples & FM 5-501 \\
\hline $\begin{array}{l}\text { Early sampling of fresh concrete from revolving drum truck } \\
\text { mixers or agitators }\end{array}$ & \\
\hline Low Levels of Chloride in Concrete and Raw Materials & FM 5-516 \\
\hline Yield Test & FM 1-T 121 \\
\hline Temperature & ASTM C 1064 \\
\hline Sampling Fresh Cement Concrete & FM 1-T 141 \\
\hline $\begin{array}{l}\text { Time of Setting of Concrete Mixtures by Penetration } \\
\text { Resistance }\end{array}$ & FM 1-T 197 \\
\hline
\end{tabular}

*Use the same type of meter for Quality Control tests as the Department uses for Quality Assurance testing. Where selecting pressure type meters, use an aggregate correction factor determined by the concrete producer for each mix design to be tested. Record and certify test results for correction factors for each type of aggregate at the plant. Use the Chace Air Indicator method for estimates only, and not for acceptance measurements.

**To determine when a precast member or a structure may be put into service, when a prestress force may be transferred, or when forms may be removed, use the results of a strength test which is the average of the compressive strengths of two test cylinders cast from concrete sampled from the LOT representing that member or structure. Cure the cylinders by methods identical to those used in curing the concrete member or structure.

\section{6-6 Control of Quality.}

346-6.1 General: Use a concrete plant approved by the Department for all concrete produced for incorporation into the work. Control Concrete production to meet the following criteria:

(1) Ensure that the average of any three consecutive strength test results does not fall below the specified minimum strength.

(2) Ensure that no strength test result falls more than $500 \mathrm{psi}[3 \mathrm{MPa}]$ below the specified minimum strength. 
If the Contractor fails to meet the above specified criteria, the Department will automatically void plant approval. To obtain plant re-approval, implement corrective actions as approved by the Engineer. The Engineer may allow the Contractor to continue any ongoing concrete placement being supplied from a plant for which approval is voided during the progress of that placement; but the Engineer will not accept concrete from an unapproved plant for any new placement.

If the Department withdraws plant approval during production for a construction project, the Contractor is solely responsible to (a) obtain another approved concrete plant to produce the concrete, or (b) await re-approval of the concrete plant, prior to any further production and placement of concrete on the construction project. The Engineer will not allow changes in Contract Time or completion dates. The Contractor shall bear all delay costs or other costs associated with plant approval or disapproval.

In addition to plant approval, the Contractor and the concrete supplier shall exercise two levels of concrete quality control.

Exercise the first level of quality control in accordance with the approved Level I Quality Control Plan requirements in the Standard Operating Procedures. Include in the Level I Quality Control Plan all control activities for the production of concrete and its transport to the point of delivery at the site.

Exercise the second level of concrete quality control in accordance with the approved Level II Quality Control Plan requirements in the Standard Operating Procedures. Include in the Level II Quality Control Plan the necessary requirements to control the quality of the concrete between the point of delivery at the site and the final placement location, and other requirements contained in the Standard Operating Procedures.

Produce all concrete in accordance with an approved Quality Control Plan (including Level I and Level II) that has been developed and implemented by the Contractor and the concrete supplier in accordance with the Department's Standard Operating Procedures. These procedures require, in addition to a written Quality Control Plan, certified personnel and assurances that materials, plant, production, delivery and use of concrete comply with this Section.

346-6.2 Concrete Design Mix: Furnish concrete in accordance with the following requirements or order the concrete from a plant approved by the Department which has approved mix designs. 
Prior to production of any concrete, submit a proposed mix design to the Engineer. Make a separate submittal for each class of concrete and each particular combination of component materials to be used at trial mix temperatures of 70 to $85^{\circ} \mathrm{F}$ [20 to $30^{\circ} \mathrm{C}$, and for hot weather mixes as described in 346-6.2(5) at a minimum temperature of $94^{\circ} \mathrm{F}\left[35^{\circ} \mathrm{C}\right]$. Use only design mixes approved by the State Materials Office. The approved concrete mix design will remain in effect until a change is authorized in writing by the Engineer.

Include the following with the mix design submittal:

(1) The Department approved source identification number for coarse and fine aggregates, along with the size of coarse aggregate and target Fineness Modulus for fine aggregate. Identify other component materials by manufacturer, brand name, and type.

(2) The actual proportions of raw materials intended to be combined to produce the concrete.

(3) The following mix data:

(a) Historical data from a minimum of 15 consecutive Department acceptance tests of production concrete made in accordance with the proposed mix design that demonstrates that the proposed mix has met all applicable plastic and hardened concrete specification criteria herein without failure. For drilled shaft concrete to be placed in (1) a wet shaft, or (2) a dry shaft requiring a temporary removable casing, provide acceptable slump loss test results. The Engineer will not approve hot weather mixes based on historical data. When required, establish the plant standard deviation and overdesign requirements as described below.

(b) Alternatively, test data from a single trial mix which demonstrates that concrete produced using the proposed mix, designated ingredients and designated water-cement ratio will have a slump within \pm 0.5 inch $[ \pm 15 \mathrm{~mm}]$ of the target value (or for mixes utilizing HRWR, within \pm 1 inch $[ \pm 25 \mathrm{~mm}]$ of the target value), air content of $2.5 \%$ to $5 \%$ and strength required to meet an overdesign which is the minimum required strength plus 1.6 standard deviations.

(4) The chloride content of the proposed design mix. The Engineer will not approve mix designs when the chloride content of the trial mix exceeds the limits shown in 346-4.2.1.

(5) For design mixes developed for use under hot weather concreting conditions:

(a) Hold the trial mix prepared at a minimum temperature of $94^{\circ} \mathrm{F}\left[34^{\circ} \mathrm{C}\right]$ in the mixer for 90 minutes after completion of initial mixing. The Engineer will not require extended mixing for precast/prestressed concrete when centrally mixed at the placement site.

On completion of the extended mixing period, ensure that the trial mix concrete has a slump within \pm 0.75 inch $[ \pm 20 \mathrm{~mm}]$ of the target value $( \pm 1$ inch $[ \pm 25 \mathrm{~mm}]$ for mixes utilizing 
HRWR), and an air content between $2 \%$ and $5 \%$.

Ensure that the mix temperature at the end of the extended mixing period is not less than $94^{\circ} \mathrm{F}\left[35^{\circ} \mathrm{C}\right]$.

During the extended mixing period, turn the drum intermittently for 30 seconds every five minutes. Cover the drum with wet burlap or an impermeable cover material during the rest periods.

At the end of the 90-minute period, remix the trial mix for a minimum of one minute and make a slump test to verify that the concrete is within the specified range for slump. If below the target range, the Contractor may adjust the slump by a water addition. After the water addition, remix the concrete for a minimum of two minutes.

The total water used in initial mixing and the final slump adjustment constitutes the design mix water content. Ensure that the total water content does not exceed the maximum water cement ratio of Table 346-3 for the respective class of concrete.

(b) Ensure that the heat of hydration of the cement does not exceed $80 \mathrm{cal} / \mathrm{g}[335 \mathrm{~kJ} / \mathrm{kg}]$ at seven days measured as the average of three samples, and that no individual measurement exceeds $90 \mathrm{cal} / \mathrm{g}[375 \mathrm{~kJ} / \mathrm{kg}]$.

Where fly ash is $18 \%$ or greater or slag is $50 \%$ or greater of the total cementitious material, ensue that the heat of hydration of the cement does not exceed $88 \mathrm{cal} / \mathrm{g}[370 \mathrm{~kJ} / \mathrm{kg}]$ at seven days measured as the average of three samples, and ensure that no individual measurement exceeds $96 \mathrm{cal} / \mathrm{g}[400 \mathrm{~kJ} / \mathrm{kg}]$.

Do not apply these requirements to Type III cement, as allowed in 346-2.2, when used for precast and prestressed superstructures; do not apply these requirements to cements used for steam cured concrete.

(c) Supplement standard curing practices with additional methods, supplies or equipment which further reduce moisture loss from exposed surfaces during the required 72-hour curing period. These methods may include but are not limited to the following examples:

(1) Continuous or intermittent regular water fogging.

(2) Insulated curing blankets approved by the Engineer.

(3) Curing compound applied at a rate of 1.25 times the minimum rate required in $400-16.1 .2$.

(6) For design mixes proposed for use in wet drilled shafts, demonstrate the additional requirements in 346-3.2. 
Ensure that strength test data for establishing the standard deviation of the plant proposed for use represents concrete produced to meet the specified strength of the mix submitted for approval within 1,000 psi [7 MPa]. Ensure that the strength test data represents either a group of at least 30 consecutive tests or a statistical average for two groups totaling 30 or more tests. When the Engineer cannot determine the plant standard deviation from historical data, apply an overdesign requirement, based on a singular trial mix, that is the minimum required strength plus $1,200 \mathrm{psi}$ [ $8 \mathrm{MPa}$ ] for minimum required concrete strengths of 5,000 psi [35 MPa] or less. For minimum required concrete strengths above $5,000 \mathrm{psi}$ [35 MPa], apply an overdesign requirement that is the minimum required strength plus $1,400 \mathrm{psi}$ [10 MPa].

Demonstrate the production and testing of the trial mix concrete in the presence of the Engineer. The Contractor may also demonstrate a proposed mix design at a water-cement ratio exceeding that proposed to meet the slump, air and strength requirements above (but not to exceed the maximum water-cement ratio in Table 3). The Engineer will allow the highest watercement ratio so demonstrated to provide the required overdesign strength requirements as an adjustment during production to maintain both plastic property and strength requirements of delivered concrete.

Ensure that preparation and testing of the trial mixes is performed by a laboratory acceptable to the Engineer which (1) has been inspected by the CCRL on a regular basis, with all deficiencies corrected, and under the supervision of a Specialty Engineer, or (2) meets all the requirements of ASTM C 1077. The Engineer may give consideration to approval of laboratories operating under other independent inspection programs demonstrated to be equivalent to the programs recognized in (1) and (2) above. Ensure that the 28-day strength (or strength at any other designated age) of trial mixes meets the above stated overdesign requirements to ensure that concrete sampled and tested at the point of placement has a strength exceeding the specified minimum strength in Table 2.

Do not place concretes of different compositions such that the plastic concretes may combine, except where the plans require concrete both with and without microsilica or calcium nitrite in a continuous placement. Produce these concretes using two separate design mixes. Designate the mix with microsilica or calcium nitrite as the original mix, and the mix without microsilica or calcium nitrite as the redesigned mix. Ensure that both mixes contain the same cement, fly ash or slag, coarse and fine aggregates and compatible admixtures. Submit both mixes for approval as separate mix designs, both meeting all requirements of this Section. Ensure that the redesigned mix exhibits plastic and hardened qualities which are additionally approved by the 
Engineer as suitable for placement with the original mix. The Engineer will approve the redesigned mix for commingling with the original mix and for a specific project application only. Alternately, place a construction joint at the location of the change in concretes.

346-6.3 Delivery Certification: Furnish certification to the Department with each batch of concrete delivered before unloading at the site. Certification shall be in the form of a delivery ticket on which is printed, stamped or written the information required in the Standard Operating Procedures, Attachment E.

346-6.4 Tolerances: Meet the following tolerances from target values for plastic concrete properties specified in 346-3.1:

\begin{tabular}{|c|c|}
\hline Property & Tolerance \\
\hline Slump (Non-Drilled Shaft Concrete) & \pm 1.5 inch $[ \pm 40 \mathrm{~mm}]$ \\
\hline Slump (Drilled Shaft Concrete) & \pm 1 inch $[ \pm 25 \mathrm{~mm}]$ \\
\hline Air Content & As shown in the range in Table 2 \\
\hline
\end{tabular}

The Engineer will reject concrete with slump exceeding the above tolerances or air content exceeding the ranges in Table 2. The Engineer will not allow concrete to remain in a transporting vehicle to reduce slump. Do not add water to concrete delivered to the site which is within the target range for slump (target value \pm 0.75 inch $[ \pm 20 \mathrm{~mm}]$ for non-drilled shaft concrete and \pm 1 inch $[ \pm 25 \mathrm{~mm}]$ for drilled shaft concrete), except in accordance with the approved Level II Quality Control Plan as allowed in the Standard Operating Procedures.

If the slump of non-drilled shaft concrete varies from the target value in excess of 0.75 inch [20 mm] (1 inch [25 mm] for concrete containing HRWR), immediately adjust the concrete mixture to correct the slump of succeeding batches. For concrete used in slipforms, make adjustments when the slump exceeds the target value by 0.75 inch $[20 \mathrm{~mm}]$ or is 1.5 inch [40 mm] below the target value. The Engineer will allow a reasonable time for adjustment, considering trucks already in route from the concrete plant. If the Contractor does not implement adjustments at the earliest possible time, the Engineer will reject the concrete and terminate further production until the Contractor makes corrections.

\section{6-7 Concrete Plant Requirements.}

346-7.1 General: Produce concrete at plants that qualify as approved sources in accordance with the Standard Operating Procedures for Quality Control of Concrete. 
Use equipment for handling elements, mixing concrete, handling the mixed concrete, transporting and depositing the mixed concrete that has no detrimental effect on the hardened concrete. Do not use equipment with aluminum surfaces in physical contact with the elements of concrete or mixed product.

\section{6-7.2 Measuring Materials:}

346-7.2.1 Water: Measure water by volume or weight. Whichever method is used, construct the equipment so that the accuracy of measurement is not affected by variations in pressure in the water supply line. Use a meter or weighing device capable of being set to deliver the required quantity and to automatically cut off the flow when the required quantity has been discharged. Ensure that the measuring equipment has an accuracy, under all operating conditions, within $1 \%$ of the quantity of water required for the batch. Verify the accuracy of measuring devices at the request of the Department, or at least quarterly.

The Contractor may exceed design mix water-cement ratios at the job site only if the Engineer has verified each mix to meet the minimum overdesign compressive strength requirements specified herein at the higher water-cement ratio. Adjust the mix consistency at the job site, within the allowable limit for the addition of water, only upon initial arrival of the concrete to the job site, as shown in the Level II Quality Control Plan requirements in the Standard Operating Procedures, and not thereafter.

Adjust the weight of mixing water for a concrete mix containing the corrosion inhibitor admixture calcium nitrite to account for water in the calcium nitrite solution. For each gallon [liter] of calcium nitrite solution added to the concrete, deduct 0.84 gallon [ 0.84 liter] or 7.0 pounds $[3.2 \mathrm{~kg}]$ of water from the weight of the mixing water.

346-7.2.2 Admixtures: Measure admixtures by weight or volume. Use measuring equipment that has an accuracy, under all operating conditions, within $3 \%$ of the quantity of admixture required for the batch. Measure microsilica slurry to an accuracy of $1 \%$. Ensure that the admixture supplier certifies the accuracy of measuring devices. Measure each admixture separately, and add it to the mixing water in a separate sequence as the mixing water is introduced into the mix.

For the dispensing equipment for a corrosion inhibitor admixture calcium nitrite solution, meet the requirements for measuring water as stated in 346-7.2.1. Store the calcium nitrite solution (neutral set version) in a dark container to protect against photo degradation.

The Engineer may make exceptions to the above method of admixture addition if the Contractor achieves the desired goals of each admixture and does not sacrifice the accuracy of 
measurement.

346-7.2.3 Cement, Fly Ash, Slag, and Microsilica: Measure cement, fly ash, slag, and microsilica (excluding slurries) by weight within an accuracy of $1 \%$ of the required total amount, except that for concrete batches of $3 \mathrm{yd}^{3}\left[3 \mathrm{~m}^{3}\right]$ or less, the Engineer will allow accuracy of $2 \%$. Weigh cement, fly ash, slag and microsilica separately from other materials. When weighing cement, fly ash, slag, and microsilica in a cumulative weigh hopper, weigh the cement first. Measure microsilica slurry as an admixture.

If bag cement is permitted, proportion the batch to use only whole bags.

346-7.2.4 Fine and Coarse Aggregates: Measure aggregates by weight or volume within an accuracy of $1 \%$ of the required amount. Apply aggregate surface moisture corrections.

\section{6-7.3 Batching Plants:}

346-7.3.1 Bins: Provide bins of adequate capacity for the required concrete production. Support the bins upon a rigid framework founded upon a stable foundation capable of holding them in a safe and secure position. Design each compartment to discharge efficiently and freely into the weigh hopper. Provide positive means of control so that as the quantity desired in the weigh hopper is approached, the material can be added slowly and the addition of further material can be stopped precisely. Use a discharging mechanism that prevents loss of material when it is closed. Construct aggregate storage bins sufficiently tight to prevent leakage of material, and divide them into at least one compartment for the fine aggregate and one compartment for each size of coarse aggregate to be used. Provide compartment partitions that are sufficiently tight and high enough to prevent intermingling of the several materials. Construct leak-proof and moistureproof cement bins, and provide them with vibrators or other means to aid the flow of cement from the bin.

346-7.3.2 Weigh Hoppers: Provide weigh hoppers consisting of suitable containers freely suspended from scales and protected from the elements so that accuracy is not adversely affected. Equip the hoppers with a discharge mechanism which prevents leakage or loss of material when closed. Vent hoppers to permit air to escape and equip them with vibrators or other equipment that ensures complete and efficient discharge of materials.

346-7.3.3 Scales: Provide either beam type or springless dial type scales, or electronic devices such as load cells, manufactured by a recognized scale manufacturer. Where using beam type scales, provide suitable means to hold poises securely in position after they are set. Keep scales clean and in good operating condition. Where necessary, provide the scale operator with an unobstructed view of all indicating devices and convenient access to all controls. Use graduated 
weigh beam or dials to permit reading to $0.1 \%$ of the capacity of the scales.

Prior to beginning any work, ensure that all scales and other weighing devices used in batching are checked for accuracy by a qualified representative of a scale company registered with the Bureau of Weights and Measures of the Florida Department of Agriculture.

Recheck scales once every three months or more often if deemed necessary by the Engineer. Check scales up to at least the maximum load normally handled on each respective scale.

Maintain cement scales, pozzolan scales, and coarse and fine aggregate scales to an accuracy of $0.5 \%$ of the maximum load normally handled.

Affix a certificate of inspection bearing the date of the certification and signed by the scale company representative to each weighing device. Make available at the plant a copy of the scale company's report corresponding with the current certificate of inspection showing the date of inspection, signature of the scale company representative, the observed scale deviations for the loads checked, and a statement that the scale meets the requirements of Chapter 531 of the Florida Statutes pertaining to specifications, tolerances and regulations, as administered by the Bureau of Weights and Measures of the Florida Department of Agriculture.

Calibrate the dispensing equipment for calcium nitrite quarterly.

\section{6-7.4 Mixers:}

346-7.4.1 General Requirements: Provide mixers of an approved type that are capable of combining the components of the concrete into a thoroughly mixed and uniform mass, free from balls or lumps of cementitious material, and that are capable of discharging the concrete with a satisfactory degree of uniformity.

346-7.4.2 Design: Use truck mixers of the inclined axis revolving drum type, or concrete plant central mixers of the non-tilting, tilting, vertical shaft or horizontal shaft types.

Make available at the batching plant at all times a copy of the manufacturer's design, showing dimensions and arrangement of blades. The Contractor may use mixers that have been altered from such design in respect to blade design and arrangement, or to drum volume, when recommended by the manufacturer and approved by the Engineer.

Ensure that metal rating plates are attached to each mixer specifying its mixing speed, agitating speed, rated capacity and unit serial number.

346-7.4.3 Truck Mixers: Use truck mixers with a drum that is actuated by a power source independent of the truck engine or by a suitable power take-off. Ensure that either system used provides control of the rotation of the drum within the limits specified on the manufacturer's 
rating plate, regardless of the speed of the truck. Use truck mixers of the revolving drum type that are equipped with a hatch in the periphery of the drum shell which permits access to the inside of the drum for inspection, cleaning and repair of the blades.

Use truck mixers equipped with revolution counters of an approved type and mounting, by which the number of revolutions of the drum may be readily verified.

Ensure that the water supply system mounted on truck mixers is equipped with a volumetric water gauge or approved water meter in operating condition. Calibrate water measuring devices on truck mixers or other water sources used for concrete water adjustments annually.

Where job site water additions are controlled by a truck mixer volumetric gauge, park truck mixers in a level condition during on-site water adjustments so that the gauge is indicating a specific tank volume before and after the concrete adjustment. When water additions exceed $4 \mathrm{gal} / \mathrm{yd}^{3}\left[20 \mathrm{~L} / \mathrm{m}^{3}\right]$ of concrete, ensure that the water measuring equipment has an accuracy of within $3 \%$ of the indicated quantity.

346-7.4.4 Timers: Use stationary type mixers equipped with an approved timing device which will automatically lock the discharge lever when the drum is charged and release it at the end of the mixing period. In the event of failure of the timing device, the Engineer may allow operations to continue. Do not extend such operations beyond the end of that working day.

346-7.4.5 Cleaning and Maintenance of Mixers: Repair or replace mixer blades of revolving drum type mixers when the radial height of the blade at the point of maximum drum diameter is less than $90 \%$ of the design radial height. Repair or adjust mixers of other designs per manufacturer's instructions. Resolve questions of performance through mixer uniformity tests as described in ASTM C 94.

346-7.5 Trucks for Transporting Wet Batches: The Contractor may transport wet batches of concrete in either agitating or nonagitating trucks. Provide nonagitating trucks with bodies that are smooth, mortar tight containers with round internal corners, and capable of discharging the concrete at a satisfactorily controlled rate without segregation. Provide covers for nonagitating trucks for protection from the elements.

\section{6-8 Mixing and Delivering Concrete.}

346-8.1 General Requirements: Operate truck mixers at mixing speeds of 6 to $18 \mathrm{rpm}$ and agitating speeds of 2 to $6 \mathrm{rpm}$ (of the drum). Operate concrete plant mixers at speeds per the manufacturer's design or recommendation. Do not allow the volume of material mixed per batch 
to exceed the manufacturer's rated mixing capacity.

346-8.2 Central Mixing: After all materials are in the mixer, mix the concrete a minimum of two minutes or the manufacturer's recommended minimum, whichever is longer, unless a reduced mixing time is authorized by the Department. Mix concrete containing microsilica in accordance with the microsilica supplier's recommendations.

346-8.3 Transit Mixing: Initially mix each batch between 70 and 100 revolutions of the drum at mixing speed. When water is added at the job site, mix the concrete 30 additional mixing revolutions. When mixing for the purpose of adjusting consistency, do not allow the total number of revolutions at mixing speed to exceed 160 . Discharge all concrete from truck mixers before total drum revolutions exceed 300 .

Do not haul concrete in mixer trucks loaded with more than the rated capacity shown on their attached plates.

346-8.4 Mixing at the Site: For mixing concrete at the job site, use a mixer of sufficient capacity to prevent delays that may be detrimental to the quality of the work. Ensure that the accuracy of batching equipment is in accordance with requirements of this Section.

346-8.5 Charging the Mixer: Charge each batch into the drum so that some water enters both in advance of and after the cementitious material and aggregates. If using fly ash in the mix, charge it into the drum over approximately the same interval as the cement. Introduce microsilica into the mixer in accordance with the microsilica supplier's recommendations. The Contractor may use other time intervals for the introduction of fly ash into the mix when the Contractor demonstrates, using test requirements specified in ASTM C 94, that he can achieve uniformity of the concrete mix.

For concrete mixes containing the corrosion inhibitor calcium nitrite, charge the batch materials into the mixer in a sequence recommended by the calcium nitrite supplier.

346-8.6 Concreting in Cold Weather: Do not mix concrete when the air temperature is below $45^{\circ} \mathrm{F}\left[7^{\circ} \mathrm{C}\right]$ and falling. The Contractor may mix and place concrete when the air temperature in the shade, and away from artificial heat, is above $40^{\circ} \mathrm{F}\left[4^{\circ} \mathrm{C}\right]$ and rising. Do not heat aggregates or use salts to reduce the freezing temperature. Protect the fresh concrete from freezing until the concrete reaches a minimum compressive strength of 1,500 psi [10 MPa]. Do not apply this requirement where concrete is to be heat cured.

346-8.7 Concreting in Hot Weather: Hot weather concreting is defined as the production, placing and curing of concrete when the concrete temperature at placing exceeds $85^{\circ} \mathrm{F}$ $\left[30^{\circ} \mathrm{C}\right]$ but is less than $100^{\circ} \mathrm{F}\left[40^{\circ} \mathrm{C}\right]$. 
Unless the specified hot weather concreting special measures are in effect, including a design mix complying with $346-6.2$, the Engineer will reject concrete exceeding $85^{\circ} \mathrm{F}$ [ $\left.30^{\circ} \mathrm{C}\right]$ at the time of placement. Regardless of special measures taken, the Engineer will reject concrete exceeding $100^{\circ} \mathrm{F}\left[40^{\circ} \mathrm{C}\right]$. Predict the concrete temperatures at placement time and implement hot weather measures to avoid production shutdown.

When the corrosion inhibitor calcium nitrite is used in a hot weather concrete mix, use a water reducing retardant admixture (Type D) and a high range water reducing admixture (Type F), and place the concrete in the early morning or at night.

346-8.8 Transit Time: Ensure compliance with the following maximum allowable time between the initial introduction of water into the mix and depositing the concrete in place:

\begin{tabular}{|c|c|}
\hline Non-Agitator Trucks & Agitator Trucks \\
\hline 45 minutes & 60 minutes \\
\hline 75 minutes* & 90 minutes* \\
\hline
\end{tabular}

* When a water reducing and retarding admixture (Type D or Type $G$ ) is used.

All time limits are subject to the ability of the Contractor to properly place and consolidate the concrete. When unable to place and consolidate the concrete within the time limits specified above, reduce the time limits to those limits which will result in acceptable placement and consolidation.

\section{6-9 Plastic Concrete Verification Sampling and Testing.}

The Department will make initial verification tests on a sample from the initial delivery of each class of concrete to the job site each day to ensure compliance with the requirements in this Section for air content, temperature and slump. Furnish the Engineer sufficient concrete of each design mix as required by the Engineer for verification testing. Do not proceed with the placement operation until the delivered concrete complies with the specified tolerances in this Section for the plastic concrete. The Engineer will reject non-complying loads which cannot be adjusted at the job site in accordance with 346-6.4 and the Standard Operating Procedures. Ensure that corrections are made by the concrete producer on subsequent loads.

After the Contractor begins concrete placement, the Department will make intermediate verification tests, as determined necessary by the Engineer, to ensure compliance with specification requirements for concrete plastic properties. The Engineer will reject noncomplying loads which cannot be adjusted at the job site in accordance with 346-6.4 and the Standard Operating Procedures. 
If the Engineer obtains an intermediate verification test failure of a load of concrete before any concrete from that load is placed, the Engineer will reject the load. Continue placement operations with the next load that is in compliance with requirements for air content, temperature and slump. The Engineer will not terminate the LOT.

If the Engineer obtains an intermediate verification test failure of a load of concrete that has been partially placed, The Engineer will reject the remainder of that load and terminate the LOT. The Engineer will make acceptance cylinders representing that LOT from the same sample of concrete unless acceptance cylinders have previously been made representing that LOT.

Following termination of a LOT, the Engineer will re-initiate initial verification tests until such time as the air content, temperature and slump comply with specification requirements. The Engineer will initiate a new LOT once the testing indicates compliance with specification requirements.

When three consecutive LOTs, or when five LOTs in two days of production of the same design mix are outside the specified tolerances, suspend production. Make the necessary revisions to concrete operations or the Quality Control Plan to bring the concrete within allowable tolerances. Obtain the Engineer's approval of the revisions prior to resuming production.

\section{6-10 Acceptance Sampling and Testing.}

346-10.1 General: The Department will make acceptance testing on samples of the concrete delivered to the job site. Furnish the Engineer sufficient concrete of each design mix as required by the Engineer for acceptance testing.

Furnish and maintain, throughout the required curing period, facilities suitable for curing concrete test cylinders in accordance with the requirements of FM 1-T 023 including power supply, equipment and materials necessary for proper operation.

346-10.2 Sampling Frequency for Acceptance Tests: The Engineer will randomly sample and test concrete for each design mix for air content, temperature, slump and compressive strength in accordance with the following schedules as a minimum. The Engineer will select acceptance samples from each LOT on a random basis to represent the entire LOT of concrete. The Engineer may perform additional sampling and testing to satisfy the Department's Material Sampling, Testing and Reporting Guide requirements. If the Contractor stops concrete placement for more than 90 minutes, the Engineer will initiate a new LOT when the Contractor restarts concrete placement. The Engineer will terminate a LOT when any acceptance test fails. 


\begin{tabular}{|c|c|}
\hline Class Concrete & Maximum LOT Size \\
\hline I (Pavement) & $\begin{array}{r}1 \mathrm{mile}[1.5 \mathrm{~km}] \text { or } 1 / 2 \text { day's production, } \\
\text { whichever is less }\end{array}$ \\
\hline I (Special) & $\begin{array}{c}150 \mathrm{yd}^{3}\left[125 \mathrm{~m}^{3}\right] \text { or one day's production, } \\
\text { whichever is less }\end{array}$ \\
\hline $\begin{array}{c}\text { II, II (Bridge Deck), III, IV, IV (Drilled Shaft), } \\
\text { V (Special), V, VI }\end{array}$ & $\begin{array}{c}50 \mathrm{yd}^{3}\left[40 \mathrm{~m}^{3}\right], \text { or one day's production, } \\
\text { whichever is less }\end{array}$ \\
\hline III (Seal) & Each Seal placement \\
\hline
\end{tabular}

346-10.3 Strength Test Definition: The Department will determine a strength test for a LOT as the average of the compressive strengths of two test cylinders cast from a sample of concrete from the LOT, except that if one test cylinder shows evidence of improper sampling, molding, handling, curing or testing, the Engineer will disregard that cylinder and the Department will determine the compressive strength value for the LOT as the test result of the remaining cylinder.

346-10.4 Acceptance of Hardened Concrete: The Engineer will accept (or reject) hardened concrete on the basis of strength test results as defined in 346-10.3. The Engineer will not discard a cylinder strength test result based on low strength (strength below the specified minimum strength as per the provisions of 346-3 and 346-10). The Engineer will accept at full pay only LOTs of concrete represented by strength test results which equal or exceed the respective specified minimum strength. The Department will obtain strength test results at the frequency specified in 346-10.2.

\section{6-11 Investigation of Low Strength Concrete for Structural Adequacy.}

346-11.1 General: When a concrete acceptance strength test result falls more than $10 \%$ or $500 \mathrm{psi}$ [ $3.5 \mathrm{MPa}$ ] below the specified minimum strength, whichever is the lesser deviation from the specified minimum strength, and when the Department determines that an investigation is necessary, the Department will make an investigation into the structural adequacy of the LOT of concrete represented by that strength test result.

346-11.2 Determination of Structural Adequacy: When the Department determines a need to investigate structural adequacy, perform a structural analysis as shown in (b) below or take drilled core samples to determine the in-place strength of the LOT of concrete in question. If 
the Contractor takes cores, both the Contractor and the Department shall accept the core strength test results obtained as the in-place strength of the LOT of concrete in question. These core strength test results will be final and used in lieu of the cylinder strength test results for determination of structural adequacy.

If drilled cores are taken and the core strength test results are less than $10 \%$ below the specified minimum strength, and this deviation from the specified minimum strength does not exceed $500 \mathrm{psi}$ [3.5 MPa], consider the concrete represented by the cores structurally adequate. If the core strength test results are more than $10 \%$ or $500 \mathrm{psi}[3.5 \mathrm{MPa}$ ] below the specified minimum strength, whichever is the lesser deviation from the specified minimum strength, the Department will consider the concrete represented by the cores structurally questionable. Then the Contractor may either:

(a) Remove and replace the LOT of concrete in question at no additional expense to the Department, or

(b) Submit a structural analysis performed by a Specialty Engineer. If the results of the analysis, approved by the Department, indicate adequate strength to serve its intended purpose with adequate durability, the Contractor may leave the concrete in place. Otherwise, remove and replace the LOT of concrete in question at no additional expense to the Department.

The Engineer may accept low strength concrete at reduced payment in accordance with the provisions of 346-12.

346-11.3 Coring for Determination of Structural Adequacy: If the Contractor uses core samples from the hardened concrete to determine structural adequacy, the Contractor shall obtain the cores and repair the core holes. Drill the cores at the same approximate locations from which the test cylinder concrete was obtained, as approved by the Engineer. Select the location of the drilled cores so that the structure is not impaired and does not sustain permanent damage after repairing the core holes. When the Contractor supplies drilled core samples, the Engineer will require three undamaged samples. The Engineer will not accept cores taken without Department approval.

346-11.4 Core Conditioning and Testing: If the Contractor provides drilled core samples for determination of structural adequacy, the Department will test the cores in accordance with FM 1-T 024. The Department will immerse the cores in water for at least 40 hours, and test the cores wet.

346-11.5 Core Strength Representing In-Place Concrete Strength: The Department will consider the core strength obtained as the in-place concrete strength for structural 
determinations of the LOT of concrete in question. The Department will calculate the strength value to be the average of the compressive strengths of the three individual cores. The Department will accept this strength at its actual measured value, as determined by FM 1-T 024 .

\section{6-12 Pay Adjustments for Low Strength Concrete.}

346-12.1 General: The Engineer may accept any LOT of concrete failing to meet the specified minimum strength as defined in 346-3, 346-10 and 346-11 when the Department determines that the concrete has been adequately consolidated, cured, and satisfactorily meets all other requirements of the Contract Documents, including structural adequacy. The Engineer will individually reduce in price, in accordance with 346-12, any LOT of low strength concrete accepted.

346-12.2 Basis for Pay Adjustments: When a concrete acceptance strength test result falls more than $10 \%$ or $500 \mathrm{psi}$ [ $3.5 \mathrm{MPa}$ ] below the specified minimum strength, whichever is the lesser deviation from the specified minimum strength, the Contractor may elect to drill core samples from the respective LOT of concrete represented by the low acceptance strength test result for determining pay adjustments.

When cores are not taken, the Engineer will determine payment reductions based upon the results of strength tests performed on acceptance sample cylinders required in accordance with 346-10.

When the Contractor elects to supply drilled cores and submits acceptable drilled core samples to the Engineer for testing, the Engineer will determine payment reductions based upon the results of strength tests performed on those cores. Both the Contractor and the Department shall accept the results of strength tests of the drilled cores, subject to 346-12.5 and 346-12.6, as final and in lieu of the cylinder strength test results for determining pay adjustments.

Do not core hardened concrete for determining pay adjustments when the 28-day acceptance cylinder strength test results are less than $10 \%$ below the specified minimum strength, and this deviation from the specified minimum strength does not exceed $500 \mathrm{psi}$ [3.5 MPa].

346-12.3 Coring for Determination of Pay Adjustments: If the Contractor elects to drill core samples from the hardened concrete for determination of pay adjustments, obtain the cores in accordance with 346-11.3.

346-12.4 Core Conditioning and Testing: If the Contractor elects to provide drilled core samples for determination of pay adjustments, the Department will test the cores in accordance with 346-11.4. 
346-12.5 Core Strength Representing Equivalent 28-Day Strength: For cores tested no later than 42 days after the concrete was cast, the Engineer will accept the core strengths obtained as representing the equivalent 28-day strength of the LOT of concrete in question. The Department will calculate the strength value to be the average of the compressive strengths of the three individual cores. The Department will accept this strength at its actual measured value, as determined by FM 1-T 024.

346-12.6 Core Strength Adjustments: For cores tested later than 42 days after the concrete was cast, the Department will establish the equivalency between 28-day strength and strength at ages after 42 days based on test data developed by a Department approved testing laboratory to relate strength at the actual test age to 28-day strength for the particular class of concrete and design mix represented by the cores. Obtain such data at no additional expense to the Department. When such data is not available and cannot be produced, as determined by the Department, the Department will determine the equivalent 28-day strength by adjusting the tested core strengths according to the following relationship:

Equivalent 28-Day Strength $=\underline{\text { Average Core Strength X } 100}$

where:

$$
\begin{array}{cc}
F=4.4+39.1(\ln x)-3.1(\ln x)^{2} & \text { (Type I Cement) } \\
F=-17.8+46.3(\ln x)-3.3(\ln x)^{2} & \text { (Type II Cement) } \\
F=48.5+19.4(\ln x)-1.4(\ln x)^{2} & \text { (Type III Cement) } \\
& x=\text { number of days since the concrete was placed } \\
\ln =\text { natural } \log &
\end{array}
$$

346-12.7 Calculating Pay Adjustments: The Engineer will determine payment reductions for low strength concrete accepted by the Department and represented by either cylinder or core strength test results below the specified minimum strength, in accordance with the following:

Reduction in Pay $=\$ 0.80 / \mathrm{yd}^{3}\left[\$ 1.05 / \mathrm{m}^{3}\right]$ for each $10 \mathrm{psi}[70 \mathrm{kPa}]$ of strength test value below the specified minimum strength.

The Engineer will denominate low strength concrete paid on a per foot [meter] basis in cubic yards [cubic meters] by multiplying the plan cross-section of the element incorporating the low strength concrete by the full length of that element, or by 150 feet [45 $\mathrm{m}$ ], whichever is less.

The Engineer will apply a reduction in pay to the entire LOT of concrete represented by the low strength test results except as noted above for concrete paid on a per foot [meter] basis, where the amount might exceed one LOT. 


\begin{abstract}
APPENDIX C
FLORIDA DEPARTMENT OF TRANSPORTATION

DRILLED-SHAFT FOUNDATIONS MIX DESIGN
\end{abstract}




\section{APPFOVED}

DRTE QCT. 30.1998

BY

DETRIET VAATERIRLS ENGRONGRETE MIX DESIGN

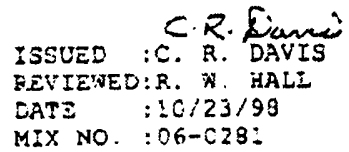

$\# 12: 13: 31$

CONCFEIE SUPYLIER: RINKER UATERIALS CORP

RDDRESS: 1501 BELVEDERE ROFD

PLANT LOGATION: LEJEUNE

EDOT ASSIGNED PLANT NO.:87-0E5

DATE: $10 / 22 / 98$

\author{
PEST PALM PEACH, EL 33406 \\ TELEFHONO NO:553/833-5555 \\ PROJECI NO: $87000-360$ :
}

CHASS CONCRETE: IV ORILL SHATT HCOCPSI

SOURCE CF MATEREALS

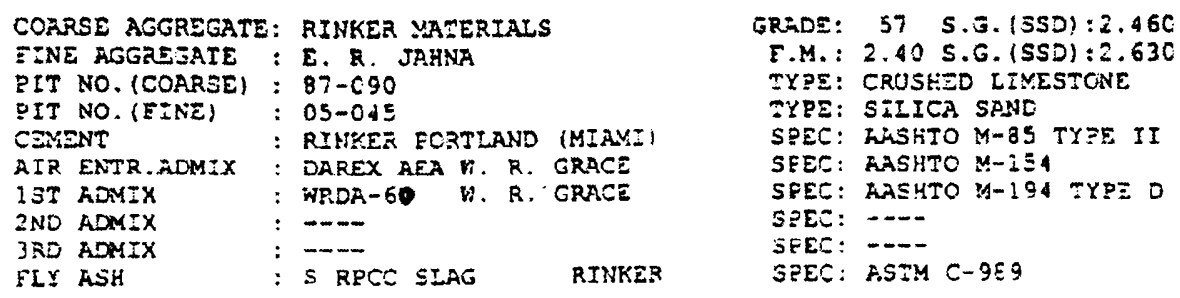

HOT WEATHER DESEGN MTX

\$ BLAST FURNACE SLAG

CEMENT $\{\mathrm{Kg}$ ) LBS

COARSZ AGG (Kg) IBS

FINE AGG (Kg) LBS

AIR EN? ADMX (mI) OL

ISI ALMIXIURE (mL: OZ

2ND ACMIX imL) OZ

3RD ADMIX ( $\mathrm{mL}$ ) OZ

TAMER (ML) GR

WAFER (Kg) IBS

FLY ASH !Kg; ZBS

Ec:

U. M. S. 4 \&

TEST EILE

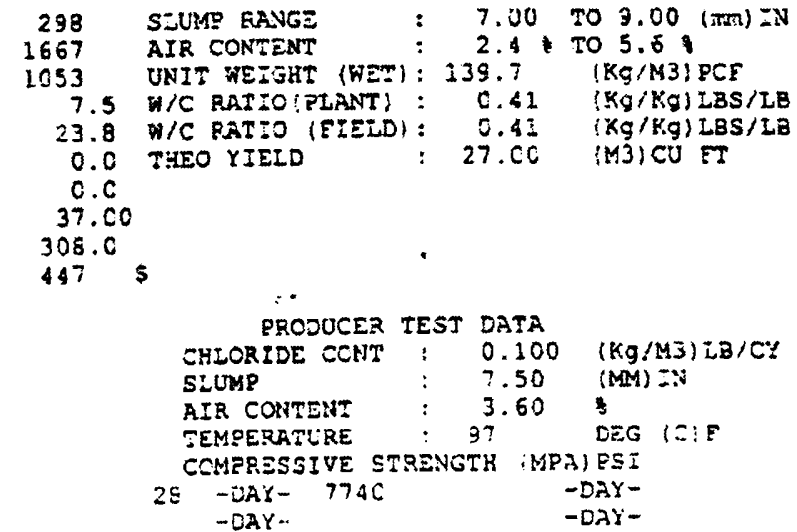


APPENDIX D

AMERICAN CONCRETE INSTITUTE

ACI 211 


\section{APPENDIX D}

\section{D.1: AMERICAN CONCRETE INSTITUTE 211}

"Standard Practice for Selecting Proportions for Normal, Heavyweight, and Mass Concrete" (ACI 211.1) is the most widely used guide for concrete mix design. The method has a sound technical basis and provides a first approximation of proportions. But as with any other method, calculated proportions are subject to revision on the basis of experience with trial batches. The major steps are outlined by Mr. Jerry Rose in his "Concrete Mix Design" paper and are as follows:

1) Choose the slump range and nominal maximum size of coarse aggregate for the type of construction and placing conditions. Guidelines are given based on experience with materials to provide the required workability.

2) Use tables to approximate the mixing water and air content requirements for different slumps, aggregate maximum sizes, and exposure conditions. Adjustments can be made for different aggregate textures and shapes, or the inclusion of chemical admixtures and workability agents. Some specifications limit the mixing water permitted in the mix.

3) Select the water-cement or water-cementitious material ratio to meet strength and durability requirements. Tables relate these factors to expected compressive strengths and durability levels. The recommended values for strength are conservative. To produce the lowest cost mix, it's best to develop relationships between strength and water-cementitious ratio for the materials actually being used.

4) Calculate the amount of cementitious material needed per unit volume of concrete by dividing the weight of mixing water required by the water-cementitious ratio. Some specifications give minimum allowable cement contents. If the calculated amount is less than a specified use the minimum amount instead. 
5) Use the table in ACI 211.1 to estimate the dry-rodded volume of coarse aggregate needed to produce satisfactory workability for normal conditions. The volume of coarse aggregate needed is primarily dependent on the coarse aggregate maximum size and fineness modus of the fine aggregate. Multiply the volume by the dry rodded unit weight to get the weight of coarse aggregate needed.

6) Sum the solid volumes of water, cementitious materials, air, and coarse aggregate and subtract them from the unit volume to calculate the solid volume of fine aggregate needed. Multiply the solid volume by the solid unit weight for fine aggregate to get the weight of fine aggregate needed.

7) On jobs where the optimum ratio of fine to coarse aggregate is known, based on experience, the coarse aggregate table doesn't have to be used. Instead, determine how much volume must be filled by aggregate and proportion the amount of coarse and fine aggregates to yield the optimum ratio.

8) Aggregate design weights can be calculated assuming either a saturated surface dry or oven dry moisture condition. These are standard definable moisture contents and aggregate specific gravities are calculated for both conditions.

\section{Trial Batches}

The final phase of mix design is checking calculated mixture proportions by making laboratory trial batches or full-sized field batches. Only enough water should be added to produce the required slump, regardless of the amount assumed when selecting trial proportions. Check the concrete unit weight and yield, air content, and temperature at the specified slump. Evaluate workability, freedom from segregation, and finishable.

Make adjustments as needed in the proportions of subsequent ' batches. For example, dosage of air entraining agent can be changed to adjust air content. If the actual 
water content doesn't match the design value, adjust the cementitious content to maintain the desired water cementitious ratio. Also adjust aggregate weights to maintain the correct yield.

After determining the mix proportions that produce the required slump, air content, and yield, makes strength test specimens for testing. The average strength must exceed the design strength by a sufficient margin to keep the number of low tests below specified limits.

Specific examples of mix design calculations and adjustments are given in ACI 211.1, published by other agencies such as the Portland Cement Association also give example mix design calculations In their publications. Remember, however, that properties of most mixes should be verified with trial batches before the concrete is used on a job. 
APPENDIX E

RESULTS OF PHASE I AND II

GRADING RESULTS 1 TO 7 
E.1 Test Butch Hl; Discharge Rate

\begin{tabular}{|c|c|c|c|c|c|c|c|}
\hline \multicolumn{8}{|c|}{ E.1.1 Butch Deta } \\
\hline \multicolumn{2}{|c|}{ Date } & \multicolumn{2}{|l|}{$: 4 / 9 / 2001$} & \multicolumn{2}{|c|}{ Discharge Rate } & \multicolumn{2}{|c|}{200 \#/sec } \\
\hline \multirow{2}{*}{\multicolumn{2}{|c|}{$\begin{array}{l}\text { Drin Shaft Mix Ho. } \\
\text { Truck Mixer No. }\end{array}$}} & \multirow{2}{*}{\multicolumn{2}{|c|}{$\begin{array}{l}: 06-0081 \\
: 2969\end{array}$}} & \multicolumn{2}{|c|}{ Thuck Shmp Gegr } & \multicolumn{2}{|c|}{$: 4.9 \mathrm{n}$} \\
\hline & & & & \multicolumn{2}{|c|}{ Visual Slmp } & \multicolumn{2}{|l|}{$: 8.0 \mathrm{n}$} \\
\hline \multicolumn{2}{|c|}{ He edwater } & $: 90 \%$ & $: 10 \%$ & \multicolumn{2}{|c|}{$\begin{array}{l}\text { Loed Sirse } \\
\text { Mixing Spe ed }\end{array}$} & \multicolumn{2}{|c|}{$\begin{array}{l}: 9 \text { cuyds } \\
: 12 \text { rpm }\end{array}$} \\
\hline \multicolumn{8}{|c|}{ E1.2 Butch Recoud } \\
\hline Materials & $\begin{array}{l}\text { Source } \\
\text { andiru } \\
\text { Type }\end{array}$ & Mix Desien & Tar get Wh ight & $\begin{array}{l}\text { Artual } \\
\text { weigits }\end{array}$ & Tolenerces & $\begin{array}{l}\text { Auto ar } \\
\text { Mrowal }\end{array}$ & Mbisture Percent \\
\hline$\# 57$ & Rinker & $1,667 \mathrm{bs}$ & $15,288 \mathrm{Ib}$ & $15,400 \mathrm{~b}$ & IN & Auto & $1.90 \%$ \\
\hline Sand & Ortoma & $1,053 \mathrm{bs}$ & $9,557 \mathrm{Ibs}$ & 9,900 bs & UUT & Auto & $1.90 \%$ \\
\hline Cemert & $\begin{array}{l}\text { Type II } \\
\text { Rinker }\end{array}$ & $298 \mathrm{Ibs}$ & 2,582 Ibs & 2,680 bs & IN & Auto & \\
\hline Slag & Rinkex & $447 \mathrm{Ibs}$ & 4 D23 Ibs & 4 مוر bs & IN & Manal & \\
\hline$A \dot{r}$ & $\begin{array}{l}\text { Derex } \\
\text { (Gence) }\end{array}$ & $20 z$ & 54 or & 53 ox & IN & Autt & \\
\hline Retarder & $\begin{array}{l}\text { WRDA } \\
60 \text {; Chace }\end{array}$ & $80 x$ & $2140 z$ & $2150 \mathrm{x}$ & IN & Auto & \\
\hline Water & weIl & $37 \mathrm{gal}$ & $249 \mathrm{gal}$ & 249 ol & IN & Auto & \\
\hline \multicolumn{8}{|c|}{ 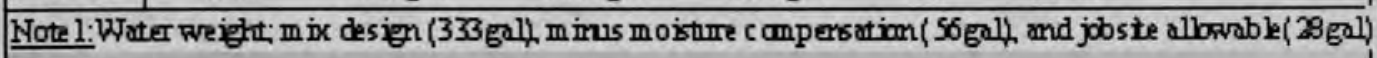 } \\
\hline \multicolumn{8}{|c|}{ E 13 Batch Carcrete Properties } \\
\hline & Shmp & $A \dot{x} \%$ & Tempentume & $\begin{array}{l}\text { Unt } \\
\text { weigit } \\
\text { (H/Cu ft) }\end{array}$ & \multicolumn{2}{|c|}{$\begin{array}{l}\text { Cylinder cest } 8 \\
7 \text {-days }\end{array}$} & $\begin{array}{l}\text { Cylinder } 8 \\
\text { 28-days }\end{array}$ \\
\hline Iruitial & $825 \mathrm{in}$ & $3.00 \%$ & N/A & 140 & \multicolumn{2}{|c|}{ N/A } & H/A \\
\hline Final & $850 \mathrm{in}$ & $2.00 \%$ & $\Leftrightarrow \mathrm{F}$ & 1416 & \multicolumn{2}{|c|}{2} & 2 \\
\hline \multicolumn{8}{|c|}{ E1.4 Shmp Stand Dete } \\
\hline & $\begin{array}{l}\text { Allowed } \\
\text { whter } \\
28 \text { el }\end{array}$ & $\begin{array}{c}\text { Visual slmp } \\
\text { N/A } \\
\end{array}$ & $\begin{array}{l}\text { No intial } \\
\text { revoltims } \\
\text { N/A }\end{array}$ & $\begin{array}{l}\text { Whter } \\
\text { adied } \\
\text { W/A }\end{array}$ & \multicolumn{2}{|c|}{$\begin{array}{l}\text { Addtional } \\
\text { rewhitions } \\
\text { N/A }\end{array}$} & $\begin{array}{c}\text { Totel \#revs } \\
\text { dischmirge } \\
85 \\
\end{array}$ \\
\hline \multicolumn{8}{|c|}{ 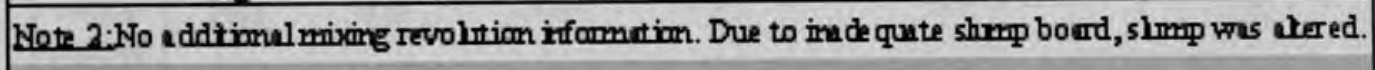 } \\
\hline \multicolumn{8}{|c|}{ E1.5 Iumps Dischreged } \\
\hline $\begin{array}{c}\text { Sime of } \\
\text { Blls }\end{array}$ & $\begin{array}{l}3 \text { to } 4 \\
\text { (in) }\end{array}$ & $\begin{array}{l}5 \text { to } 6 \\
\text { (iin) }\end{array}$ & $\begin{array}{l}7 \text { to } 8 \\
\text { (in) }\end{array}$ & $\begin{array}{l}9 \text { to } 10 \\
\text { (im) }\end{array}$ & $\begin{array}{c}11 \text { to } 12 \\
\text { (in) }\end{array}$ & $\begin{array}{l}>12 \\
\text { (iin) }\end{array}$ & Total \# of Bals \\
\hline \# of Bulk & 12 & 3 & 0 & 0 & 0 & 0 & 15 \\
\hline
\end{tabular}


E.2 Test. Buch H2; Discharge Rate (Rejected bitch, due to inadequate shimp.)

\begin{tabular}{|c|c|c|c|c|c|c|c|}
\hline \multirow{2}{*}{\multicolumn{4}{|c|}{$\begin{array}{ll}\text { Date } & : 4 / 10 / 2001 \\
\text { Drill Shaft Mix Ho. } & : 06-0281\end{array}$}} & \multicolumn{2}{|c|}{ Discharge Rate } & \multicolumn{2}{|l|}{250 Hex } \\
\hline & & & & Thuck Shamp & p Gege & \multicolumn{2}{|l|}{ : H/A } \\
\hline \multicolumn{2}{|c|}{$\begin{array}{l}\text { Truck Majoer Ho. } \\
\text { He ectwoter }\end{array}$} & $\begin{array}{l}2969 \\
: 90 \%\end{array}$ & & $\begin{array}{l}\text { Visual Slmm } \\
\text { Load Sise }\end{array}$ & & $\begin{array}{l}: 60 \text { in } \\
: 9 \text { cuyds }\end{array}$ & \\
\hline \multicolumn{2}{|c|}{ Whish worer } & $: 10 \%$ & & \multicolumn{2}{|c|}{ Mfixing Speed } & \multicolumn{2}{|l|}{$12 \mathrm{rmm}$} \\
\hline \multicolumn{8}{|c|}{ Rejexted Batch } \\
\hline \multicolumn{8}{|c|}{ E22 Butch Recond } \\
\hline Materinls & $\begin{array}{l}\text { Sourne el } \\
\text { Type }\end{array}$ & $\begin{array}{c}\text { Moix } \\
\text { Design }\end{array}$ & $\begin{array}{l}\text { Turget. } \\
\text { Weight }\end{array}$ & $\begin{array}{l}\text { Actural } \\
\text { Weights }\end{array}$ & Tolerences & $\begin{array}{l}\text { Auto or } \\
\text { Marual }\end{array}$ & $\begin{array}{l}\text { Moisture } \\
\text { Percent }\end{array}$ \\
\hline$\# 57$ & Rirker & 1607 bs & $15,258 \mathrm{Ib}$ & $15,320 \mathrm{~b}$ & IN & Auto & $1.70 \%$ \\
\hline Sund & Ortan & $1,0.3 \mathrm{bs}$ & $9.714 \mathrm{Ths}$ & $9,760 \mathrm{Ibs}$ & IN & Auto & $2.50 \%$ \\
\hline Camert & $\begin{array}{l}\text { Type II } \\
\text { Rinker }\end{array}$ & $298 \mathrm{Ibs}$ & $2 \$ 82 \mathrm{Ibs}$ & $2,700 \mathrm{Ibs}$ & IN & Auto & \\
\hline Slag & Rirker & $447 \mathrm{Ibs}$ & $4 \rho 23$ Ibs & 4,000 Ibs & IN & Marual & \\
\hline $\mathrm{A} \dot{\mathbf{r}}$ & $\begin{array}{l}\text { Derex } \\
\text { (Grace) }\end{array}$ & $20 z$ & 54 ox & 54 oz & If & Anto & \\
\hline Raterder & $\begin{array}{l}\text { WRDA } \\
64 ; \text { Gtace }\end{array}$ & $80 x$ & 214 ox & $2150 z$ & IN & Auto & \\
\hline Water & WeIl & $37 \mathrm{gal}$ & $247 \mathrm{gel}$ & $247 \mathrm{gel}$ & II & Anto & \\
\hline \multicolumn{8}{|c|}{ Wotel: Water wreight; m ix desien (333 gall minus moisture compersatim( 59 gal), and jobsite allowable(28gal) } \\
\hline \multicolumn{8}{|c|}{ E 23 Butch Carcrete Properties } \\
\hline & Slmp & $A \dot{x} \%$ & Temperature & $\begin{array}{c}\text { Unt } \\
\text { weight } \\
\text { (\#/cu ft) }\end{array}$ & $\begin{array}{l}\text { Cyinde: } \\
7-0\end{array}$ & $\begin{array}{l}\text { I cest \& } \\
\text { hys }\end{array}$ & $\begin{array}{l}\text { Cylinder cest of } \\
28 \text {-days }\end{array}$ \\
\hline Irutial & $5.50 \mathrm{n}$ & H/A & H/A & N/A & & /A. & W/A \\
\hline $\begin{array}{l}8 \text { gol } \\
\text { wuter } \\
\text { additim }\end{array}$ & N/A & H/A & H/A & H/A & H & AR. & H/A \\
\hline $\begin{array}{c}6 \mathrm{gel} \\
\text { whter } \\
\text { addition }\end{array}$ & W/A & H/A & H/A & N/A & $\mathrm{H}$ & AA & W/A \\
\hline Final & $7.00 \mathrm{in}$ & $2.25 \%$ & $82 \mathrm{~F}$ & 1423 & & 2 & 2 \\
\hline
\end{tabular}




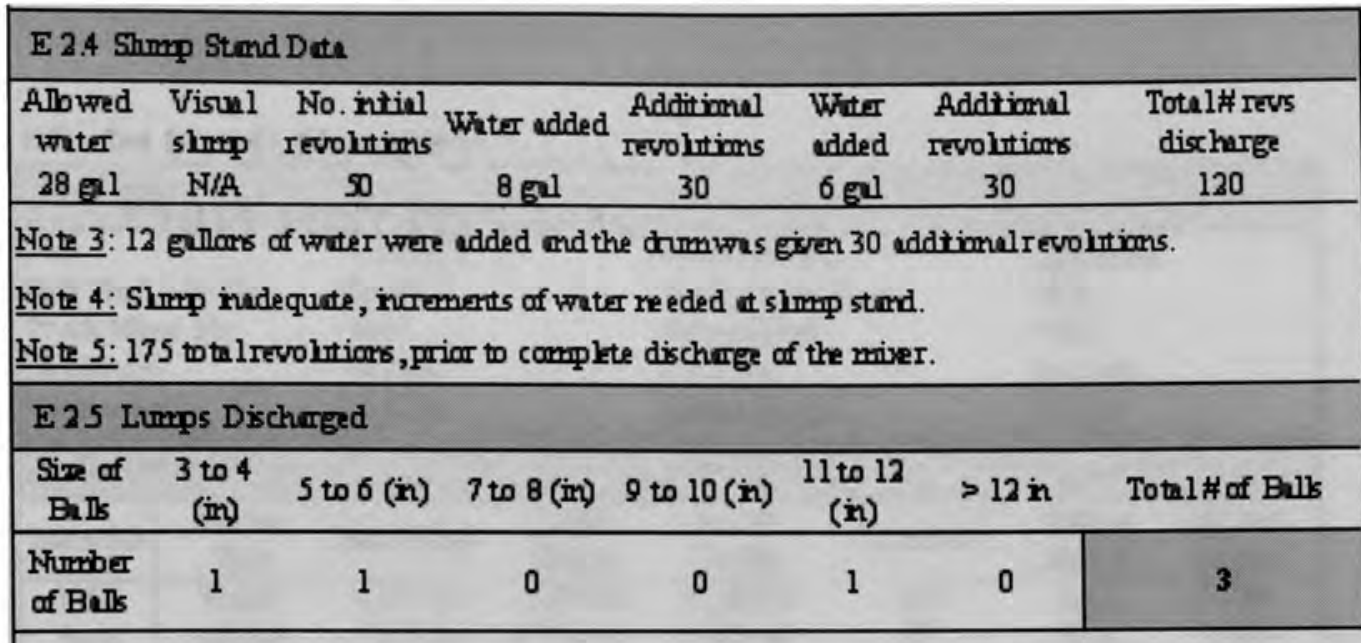

Hote 6: One bellweight 32 bs.

No te: Batch \#2 rejected, due to inadequate slump. 
E 3 Test Butch \#3; Dischirge Rate

\begin{tabular}{|c|c|c|c|c|c|c|c|}
\hline \multirow{2}{*}{\multicolumn{2}{|c|}{$\begin{array}{l}\text { Dete } \\
\text { Drill Shaft Mix Ko. } \\
\text { Truck Miver Ho. }\end{array}$}} & \multirow{2}{*}{\multicolumn{2}{|c|}{$\begin{array}{l}: 4 / 10 / 2001 \\
: 06-0281\end{array}$}} & \multicolumn{2}{|c|}{ Dixcharge Rite } & \multicolumn{2}{|c|}{250 \#/sex } \\
\hline & & & & Truck Slmp & Gage & W/A & \\
\hline \multicolumn{2}{|c|}{$\begin{array}{l}\text { He edwuter } \\
\text { Whis woter }\end{array}$} & $: 90.00 \%$ & & \multicolumn{2}{|c|}{$\begin{array}{l}\text { Loed Sime } \\
\text { Mdixing Speed }\end{array}$} & \multicolumn{2}{|l|}{$\begin{array}{l}: 9 \text { cu yds } \\
: 12 \text { rpm }\end{array}$} \\
\hline \multicolumn{8}{|c|}{ E 32 Batch Recard } \\
\hline Morterials & $\begin{array}{l}\text { Sourre- } \\
\text { Type }\end{array}$ & Mjix Design & $\begin{array}{l}\text { Target. } \\
\text { Weight }\end{array}$ & $\begin{array}{l}\text { Actural } \\
\text { Weigitit }\end{array}$ & Tolerences & $\begin{array}{l}\text { Auto or } \\
\text { Mnnuulal }\end{array}$ & $\begin{array}{l}\text { Moitare } \\
\text { Percent }\end{array}$ \\
\hline$\# 57$ & Rinker & $1667 \mathrm{bs}$ & $15,258 \mathrm{~b}$ & $5,280 \mathrm{~b}$ & IN & Auto & $1.70 \%$ \\
\hline Sand & Ortma & $1053 \mathbf{~ b s}$ & 9,714 bs & 9,700 bs & IN & Ainto & $2.50 \%$ \\
\hline Cenmert & $\begin{array}{l}\text { Type II } \\
\text { Rinker }\end{array}$ & $298 \mathrm{bs}$ & 2,682 bs & 2,600 bs & IIT & Autto & \\
\hline Slag & Rinker & 447 bs & $4,023 \mathrm{bs}$ & 4,000 bs & IN & Autto & \\
\hline$A \dot{r}$ & $\begin{array}{l}\text { Darex } \\
\text { (Grace) }\end{array}$ & $20 x$ & 54 or & 54 ox & IN & مt: & \\
\hline Retarder & $\begin{array}{l}\text { WRDA } \\
64 \text {;Grece }\end{array}$ & $80 x$ & 214 or & $2150 \mathrm{z}$ & IN & Auto & \\
\hline Wuter & Well & $37 \mathrm{gal}$ & $247 \mathrm{gel}$ & 246 gal & IN & Auto & \\
\hline \multicolumn{8}{|c|}{ 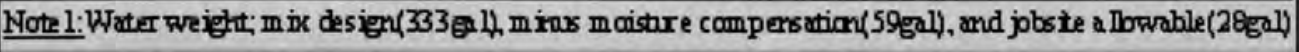 } \\
\hline \multicolumn{8}{|c|}{ E 33 Butch Carcrete Propenties } \\
\hline & Slmp & Air \% & Tempenture & \multicolumn{2}{|c|}{$\begin{array}{l}\text { Unt weight Cylinder cost Q } \\
\text { (H/fu ft) } \quad 7 \text {-doys }\end{array}$} & \multicolumn{2}{|c|}{$\begin{array}{l}\text { Cylinder cest } \\
\text { 28-days }\end{array}$} \\
\hline Iritial & 8.25 in & $250 \%$ & $85 \mathrm{~F}$ & 142 & N/A & \multicolumn{2}{|c|}{ H/A } \\
\hline Final & $7.50 \mathrm{in}$ & $200 \%$ & $84 \mathrm{~F}$ & 142 & 2 & \multicolumn{2}{|c|}{2} \\
\hline \multicolumn{8}{|c|}{ E 3.4 Shamp Stand Dite } \\
\hline & $\begin{array}{l}\text { Allowed } \\
\text { weter } \\
28 \mathrm{gal}\end{array}$ & $\begin{array}{l}\text { Visual } \\
\text { slimp } \\
\text { N/A }\end{array}$ & $\begin{array}{l}\text { No. intial } \\
\text { rewo litims } \\
\text { N/A }\end{array}$ & $\begin{array}{c}\text { Whiter } \\
\text { edded } \\
\text { N/A }\end{array}$ & $\begin{array}{l}\text { Additimal } \\
\text { revolitims } \\
\text { N/A }\end{array}$ & \multicolumn{2}{|c|}{$\begin{array}{c}\text { Totel \#revolitims } \\
\text { Q dischur ह5e } \\
120\end{array}$} \\
\hline \multicolumn{8}{|c|}{ Note 2: No addtiomalniking revolitim information avilkbl. } \\
\hline \multicolumn{8}{|c|}{ E 35 Lumps Dischrrged } \\
\hline $\begin{array}{l}\text { Sire of } \\
\text { Buls }\end{array}$ & $\begin{array}{c}3 \text { to } 4 \\
\text { (in) }\end{array}$ & $\begin{array}{c}5 \text { to } 6 \\
\text { (in) }\end{array}$ & $\begin{array}{c}7 \text { to } 8 \\
\text { (in) }\end{array}$ & $\begin{array}{l}9 \text { to } 10 \\
\text { (iin) }\end{array}$ & $\begin{array}{c}11 \text { to } 12 \\
\text { (in) }\end{array}$ & $\begin{array}{l}>12 \\
\text { (in) }\end{array}$ & $\begin{array}{c}\text { Total \# of } \\
\text { Bulk }\end{array}$ \\
\hline $\begin{array}{l}\text { Shrmber } \\
\text { of Bulls }\end{array}$ & 13 & 8 & 9 & 5 & 5 & 0 & 40 \\
\hline
\end{tabular}


E4 Test Butch \#4; Discharge Rate

\begin{tabular}{|c|c|c|c|c|c|c|c|}
\hline \multicolumn{2}{|c|}{ Dete } & \multicolumn{2}{|l|}{$: 4 / 10 / 2001$} & \multicolumn{2}{|c|}{ Discharge Rate } & \multicolumn{2}{|c|}{150 H/sex } \\
\hline \multirow{2}{*}{\multicolumn{2}{|c|}{$\begin{array}{l}\text { Drill Shaft Mix No. } \\
\text { Truck Maiver No. }\end{array}$}} & \multirow{2}{*}{\multicolumn{2}{|c|}{$\begin{array}{l}: 06-0281 \\
: 2969\end{array}$}} & \multicolumn{2}{|c|}{$\begin{array}{l}\text { Truck Slmp Guge } \\
\text { Visul Shmm }\end{array}$} & \multicolumn{2}{|c|}{$\begin{array}{l}: \text { W/A } \\
\text { : F/A }\end{array}$} \\
\hline & & & & Visuel Slmp & & N/A & \\
\hline \multicolumn{2}{|c|}{$\begin{array}{l}\text { He adwiter } \\
\text { Whis water }\end{array}$} & \multicolumn{2}{|l|}{$\begin{array}{l}: 90.00 \% \\
: 10.00 \%\end{array}$} & \multicolumn{2}{|l|}{$\begin{array}{l}\text { Loed Sime } \\
\text { Mining Speed }\end{array}$} & \multicolumn{2}{|l|}{$\begin{array}{l}: 9 \mathrm{cu} y \mathrm{ds} \\
: 12 \mathrm{rpm}\end{array}$} \\
\hline \multicolumn{8}{|c|}{ E42 Bdch Rec ard } \\
\hline Materials & $\begin{array}{l}\text { Sorrues- } \\
\text { Type }\end{array}$ & Mix Design & $\begin{array}{l}\text { Tre get } \\
\text { Whight }\end{array}$ & $\begin{array}{l}\text { Acturel } \\
\text { Whigitt }\end{array}$ & Tolerences & $\begin{array}{l}\text { Auto or } \\
\text { Mnrunal }\end{array}$ & $\begin{array}{l}\text { Mbisture } \\
\text { Percent }\end{array}$ \\
\hline$\# 57$ & Rinkex & $1567 \mathrm{bs}$ & $15,258 \mathrm{~b}$ & $15,320 \mathrm{~b}$ & IN & Auto & $1.70 \%$ \\
\hline Send & Ortme & $1053 \mathrm{bs}$ & 9,714 bs & 9,700 bs & IN & Auto & $2.50 \%$ \\
\hline Cemert & $\begin{array}{l}\text { Type II } \\
\text { Rinker }\end{array}$ & $298 \mathrm{bs}$ & 2,582 bs & 2,690 bs & IN & Auto & \\
\hline Slag & Rinker & 447 bs & $4,023 \mathrm{bs}$ & 4 م30 bs & IN & Auto & \\
\hline$A \dot{r}$ & $\begin{array}{l}\text { Derex } \\
\text { (Grece) }\end{array}$ & $20 x$ & 54 ox & 54 or & IN & Auto & \\
\hline Retarder & $\begin{array}{l}\text { WRDA } \\
64 \text {;Chace }\end{array}$ & 8 or & $2140 \mathrm{z}$ & $2150 \mathrm{x}$ & IN & Alto & \\
\hline Whiter & Well & $37 \mathrm{gal}$ & 247 gal & $246 \mathrm{gl}$ & IN & Auto & \\
\hline \multicolumn{8}{|c|}{ 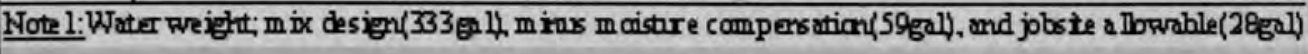 } \\
\hline \multicolumn{8}{|c|}{ E 43 Batch Corcrete Properties } \\
\hline & Slmp & Air \% & Temperutire & \multicolumn{2}{|c|}{ 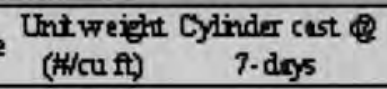 } & \multicolumn{2}{|c|}{$\begin{array}{l}\text { Cylinder cast \& } \\
\text { 28-doys }\end{array}$} \\
\hline Irütial & $7.75 \mathrm{in}$ & $200 \%$ & $82 \mathrm{~F}$ & 142 & H/A & \multicolumn{2}{|c|}{ H/A } \\
\hline Final & $7.50 \mathrm{in}$ & $200 \%$ & $84 \mathrm{~F}$ & 142 & 2 & \multicolumn{2}{|c|}{2} \\
\hline \multicolumn{8}{|c|}{ E 4.4 Shmp Stand Date } \\
\hline & $\begin{array}{l}\text { Allowed } \\
\text { wuter }\end{array}$ & $\begin{array}{l}\text { Visual } \\
\text { shmpp }\end{array}$ & $\begin{array}{l}\text { No. intial } \\
\text { rewo htims }\end{array}$ & $\begin{array}{l}\text { What } \\
\text { adiled }\end{array}$ & $\begin{array}{l}\text { Additimal } \\
\text { revolutions }\end{array}$ & \multirow{2}{*}{\multicolumn{2}{|c|}{$\begin{array}{c}\text { Total \#revolitions } \\
\text { Q dischrege } \\
85\end{array}$}} \\
\hline & $28 \mathrm{gel}$ & N/A & 40 & 9 gal & 45 & & \\
\hline \multicolumn{8}{|c|}{ Note 2: No addtional nwing revolitim information arihble. } \\
\hline \multicolumn{8}{|c|}{ E 45 Iunps Discharged } \\
\hline $\begin{array}{c}\text { Sire of } \\
\text { BIIs }\end{array}$ & $\begin{array}{c}3 \text { to } 4 \\
\text { (in) }\end{array}$ & $\begin{array}{c}5 \text { to } 6 \\
\text { (iin) }\end{array}$ & $\begin{array}{l}7 \text { to } 8 \\
\text { (in) }\end{array}$ & $\begin{array}{l}9 \text { to } 10 \\
\text { (in) }\end{array}$ & $\begin{array}{c}11 \text { to } 12 \\
\text { (in) }\end{array}$ & $\begin{array}{l}>12 \\
\text { (in) }\end{array}$ & $\begin{array}{c}\text { Total \# of } \\
\text { Bulks }\end{array}$ \\
\hline $\begin{array}{l}\text { Kroniber } \\
\text { of Bulls }\end{array}$ & 11 & 4 & 7 & 1 & 0 & 0 & 23 \\
\hline
\end{tabular}


E S Test Butch H5; Loed Sime

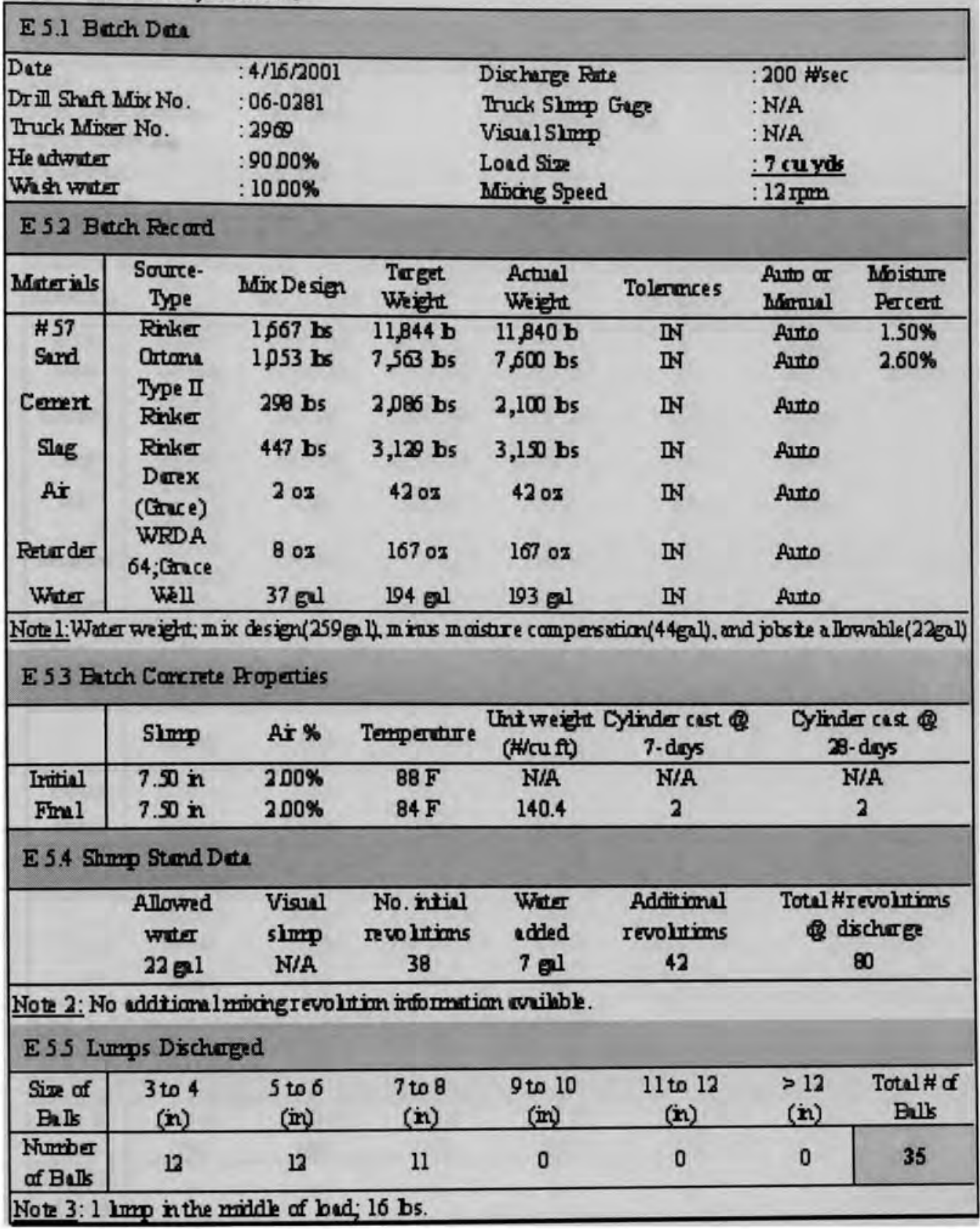


E6 Test Butch Ha; Loed Sire

\begin{tabular}{|c|c|c|c|c|c|c|c|}
\hline \multicolumn{2}{|c|}{ Dete } & $: 4 / 16 / 2001$ & & \multicolumn{2}{|c|}{ Discharge Rate } & \multicolumn{2}{|c|}{\begin{tabular}{|l} 
E 6.1 Butch Dete \\
Dete
\end{tabular}} \\
\hline \multirow{2}{*}{\multicolumn{2}{|c|}{$\begin{array}{l}\text { Drill Shaft Mix No. } \\
\text { Truck Mfincer No. }\end{array}$}} & $: 06-0281$ & & \multicolumn{2}{|c|}{ Truck Slmp Gage } & \multicolumn{2}{|l|}{$:$ W/A } \\
\hline & & & & \multicolumn{2}{|c|}{ Visual Slmmp } & \multicolumn{2}{|l|}{$:$ N/A } \\
\hline \multicolumn{2}{|c|}{ He chtruter } & $\begin{array}{l}: 9000 \% \\
: 1000 \%\end{array}$ & & \multicolumn{2}{|l|}{$\begin{array}{l}\text { Load Sixe } \\
\text { Miscing Speed }\end{array}$} & \multicolumn{2}{|l|}{$\frac{: 5 \text { cuyds }}{: 12 \text { rpm }}$} \\
\hline \multicolumn{8}{|c|}{ E 62 Batch Record } \\
\hline Moterials & $\begin{array}{l}\text { Sourre- } \\
\text { Type }\end{array}$ & Mix Design & $\begin{array}{l}\text { Treget. } \\
\text { Weight }\end{array}$ & $\begin{array}{l}\text { Actual } \\
\text { Weight }\end{array}$ & Tolerances & $\begin{array}{l}\text { Auto ar } \\
\text { Monoual }\end{array}$ & $\begin{array}{l}\text { Moistare } \\
\text { Percent }\end{array}$ \\
\hline$\# 57$ & Rinker & $1,667 \mathrm{bs}$ & $8,400 \mathrm{~b}$ & $8,440 \mathrm{~b}$ & IN & Auto & $1.50 \%$ \\
\hline Sind & Ortome & $1053 \mathbf{~ b s}$ & 5,400 bs & 5,300 bs & IN & Auto & $2.60 \%$ \\
\hline Cemert & $\begin{array}{l}\text { Type II } \\
\text { Rinker }\end{array}$ & 298 bs & 1,490 bs & 1,510 bs & IN & Auto & \\
\hline Slag & Rinker & 447 bs & 2,235 bs & 2,240 bs & IN & Auto & \\
\hline$A \dot{x}$ & $\begin{array}{l}\text { Derex } \\
\text { (Grece) }\end{array}$ & $20 x$ & $30 \mathrm{or}$ & $290 x$ & IN & Auto & \\
\hline Ratarder & $\begin{array}{l}\text { WRDA } \\
64 \text {;Gnce }\end{array}$ & $80 x$ & $119 \mathrm{oz}$ & $1200 \mathrm{x}$ & IN & Auto & \\
\hline Wuter & well & 37 gol & 139 al & 138 gel & IN & Auto & \\
\hline \multicolumn{8}{|c|}{ 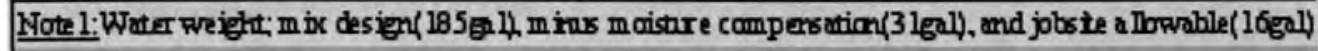 } \\
\hline \multicolumn{8}{|c|}{ E 63 Batch Carcrete Properties } \\
\hline & Slmp & $A \dot{I} \%$ & Temperume & Unt weight Cyinder cert \& & $\begin{array}{l}\text { 7-dogs } \\
\text { 7.der cest }\end{array}$ & \multicolumn{2}{|c|}{$\begin{array}{c}\text { Cylinder cest } \\
28 \text {-doys }\end{array}$} \\
\hline Iritial & $7.50 \mathrm{in}$ & N/A & $83 \mathrm{~F}$ & W/A & N/A & \multicolumn{2}{|c|}{ N/A } \\
\hline Final & $7.50 \mathrm{in}$ & $225 \%$ & $86 \mathrm{~F}$ & 141.2 & 3 & \multicolumn{2}{|c|}{2} \\
\hline \multicolumn{8}{|c|}{ E 6.4 Shmp Stand Dete } \\
\hline & $\begin{array}{l}\text { Allowed } \\
\text { wer }\end{array}$ & $\begin{array}{l}\text { Visual } \\
\text { shmp }\end{array}$ & $\begin{array}{l}\text { No. intial } \\
\text { rewo htimens }\end{array}$ & $\begin{array}{l}\text { Wuter } \\
\text { ediled }\end{array}$ & $\begin{array}{l}\text { Additional } \\
\text { revolutions }\end{array}$ & \multirow{2}{*}{\multicolumn{2}{|c|}{$\begin{array}{c}\text { Total Hr evolitions } \\
\text { \& discharge } \\
82\end{array}$}} \\
\hline & 16 ogl & N/A & H/A & N/A & N/A & & \\
\hline \multicolumn{8}{|c|}{ Note 2: No additiom lnincing r evolution information arihble. } \\
\hline \multicolumn{8}{|c|}{ E.65 Lumps Discharged } \\
\hline $\begin{array}{l}\text { Sime of } \\
\text { Bulk }\end{array}$ & $\begin{array}{c}3 \text { to } 4 \\
\text { (in) }\end{array}$ & $\begin{array}{c}5 \text { to } 6 \\
\text { (iin) }\end{array}$ & $\begin{array}{c}7 \text { to } 8 \\
\text { (in) }\end{array}$ & $\begin{array}{l}9 \text { to } 10 \\
\text { (in) }\end{array}$ & $\begin{array}{l}11 \text { to } 12 \\
\text { (in) }\end{array}$ & $\begin{array}{l}>12 \\
\text { (in) }\end{array}$ & $\begin{array}{c}\text { Total \# of } \\
\text { Blls }\end{array}$ \\
\hline $\begin{array}{l}\text { Fumber } \\
\text { of Buls }\end{array}$ & 2 & 0 & 0 & 0 & 0 & 0 & 2 \\
\hline
\end{tabular}




\begin{tabular}{|c|c|c|c|c|c|c|c|}
\hline \multicolumn{8}{|c|}{ E7.1 Betch Date } \\
\hline \multicolumn{2}{|c|}{ Date } & \multicolumn{2}{|l|}{$: 4 / 17 / 2001$} & \multicolumn{2}{|c|}{ Dischurge Rate } & \multicolumn{2}{|l|}{ : $200 \mathrm{H}$ Hec } \\
\hline \multirow{2}{*}{\multicolumn{2}{|c|}{$\begin{array}{l}\text { Drill Shaft Mix Ho. } \\
\text { Truck Miver No. }\end{array}$}} & \multirow{2}{*}{\multicolumn{2}{|c|}{$\begin{array}{l}: 06-0281 \\
: 2969\end{array}$}} & \multirow{2}{*}{\multicolumn{2}{|c|}{ Truck Shmp Gege }} & \multicolumn{2}{|l|}{$: \mathrm{N} / \mathrm{A}$} \\
\hline & & & & & & :N/A & \\
\hline \multicolumn{2}{|c|}{ He edwoter } & \multicolumn{2}{|l|}{$: 9000 \%$} & \multicolumn{2}{|l|}{ Loed Siz } & \multicolumn{2}{|l|}{ : 3 cuyds } \\
\hline \multicolumn{2}{|c|}{ Whin wrter } & $: 1000 \%$ & & \multicolumn{2}{|l|}{ Mising Speed } & \multicolumn{2}{|l|}{$12 \mathrm{rpm}$} \\
\hline \multicolumn{8}{|c|}{ E72 Butch Recond } \\
\hline Moterinls & $\begin{array}{l}\text { Sourre- } \\
\text { Type }\end{array}$ & Mix Design & $\begin{array}{l}\text { Tri get } \\
\text { Weight } \\
\end{array}$ & $\begin{array}{l}\text { Actinal } \\
\text { Weight }\end{array}$ & Tolerences & $\begin{array}{l}\text { Autro or } \\
\text { Manual }\end{array}$ & $\begin{array}{l}\text { Mbitarre } \\
\text { Percent }\end{array}$ \\
\hline$\# 57$ & Rinker & $1 \not 667 \mathrm{bs}$ & $5,0 \pi 6 \mathrm{~b}$ & $5,120 \mathbf{b}$ & IN & Auto & $1.50 \%$ \\
\hline Sand & Ortoma & $1053 \mathrm{bs}$ & 3,241 bs & 3,240 bs & IN & Auto & $2.60 \%$ \\
\hline Cenert & $\begin{array}{l}\text { Type II } \\
\text { Rinke }\end{array}$ & $298 \mathrm{bs}$ & $894 \mathrm{bs}$ & 910 bs & IN & Auto & \\
\hline Slag & Rinker & $447 \mathrm{bs}$ & 1,341 bs & $1,330 \mathrm{bs}$ & IN & Auto & \\
\hline $\mathrm{Ar}$ & $\begin{array}{l}\text { Darex } \\
\text { (Grece) }\end{array}$ & $20 x$ & $18 \mathrm{oz}$ & 17 ox & IN & Auto & \\
\hline Rater der & $\begin{array}{l}\text { WRDA } \\
64 \text {; Grace }\end{array}$ & $80 x$ & $710 \mathrm{z}$ & $720 \mathrm{x}$ & IN & Auto & \\
\hline Whe & well & $37 \mathrm{gel}$ & $83 \mathrm{gal}$ & $82 \mathrm{gel}$ & IN & Auto & \\
\hline \multicolumn{8}{|c|}{ 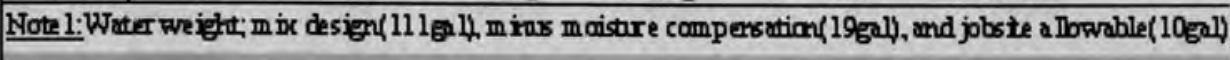 } \\
\hline \multicolumn{8}{|c|}{ E 73 Batch Corcrete Properties } \\
\hline & Shmp & Air \% & Temperarre & \multicolumn{2}{|c|}{$\begin{array}{l}\text { Unitweight Cyinder cast } \\
\text { (H/cu ft) 7-dos }\end{array}$} & \multicolumn{2}{|c|}{$\begin{array}{l}\text { Cylinder cest } \\
\text { 2B-dogs }\end{array}$} \\
\hline Irutial & $80 \mathrm{n}$ & N/A & $82 \mathrm{~F}$ & W/A & N/A & \multicolumn{2}{|c|}{ N/A } \\
\hline Fimal & 80 in & $225 \%$ & $84 \mathrm{~F}$ & 139.6 & 2 & \multicolumn{2}{|c|}{2} \\
\hline \multicolumn{8}{|c|}{ E7.4 Shmp Stand Date } \\
\hline & $\begin{array}{l}\text { Allowed } \\
\text { water }\end{array}$ & $\begin{array}{l}\text { Visual } \\
\text { slimp }\end{array}$ & $\begin{array}{l}\text { Ho, intial } \\
\text { rewo htims }\end{array}$ & $\begin{array}{l}\text { Witer } \\
\text { ediled }\end{array}$ & $\begin{array}{l}\text { Additional } \\
\text { revolutions }\end{array}$ & \multirow{2}{*}{\multicolumn{2}{|c|}{$\begin{array}{c}\text { Totel Hrevolitions } \\
\text { discharge } \\
\infty\end{array}$}} \\
\hline & 10 & N/A & 48 & 3 ol & 32 & & \\
\hline \multicolumn{8}{|c|}{ Wote 2: 107 tothlnevolitions, prior to conplete discharge of the miver. } \\
\hline \multicolumn{8}{|c|}{ E75 Lumps Discharged } \\
\hline $\begin{array}{c}\text { Sime of } \\
\text { Buls }\end{array}$ & $\begin{array}{l}3 \text { to } 4 \\
\text { (in) }\end{array}$ & $\begin{array}{l}5 \text { to } 6 \\
\text { (in) }\end{array}$ & $\begin{array}{l}7 \text { to } 8 \\
\text { (n) }\end{array}$ & $\begin{array}{l}9 \text { to } 10 \\
\text { (in) }\end{array}$ & $\begin{array}{c}11 \text { to } 12 \\
\text { (in) }\end{array}$ & $\begin{array}{l}>12 \\
\text { (in) }\end{array}$ & $\begin{array}{c}\text { Total H of } \\
\text { Bells }\end{array}$ \\
\hline $\begin{array}{l}\text { Kunmber } \\
\text { of } \mathrm{Balls}\end{array}$ & 0 & 0 & 0 & 0 & 0 & 0 & 0 \\
\hline
\end{tabular}


E8 Test Butch t Loed Sim

\begin{tabular}{|c|c|c|c|c|c|c|c|}
\hline \multicolumn{8}{|c|}{ E 8.1 Butch Dete } \\
\hline \multicolumn{2}{|c|}{ Dete } & \multicolumn{2}{|l|}{$: 4 / 17 / 2001$} & \multicolumn{2}{|c|}{ Dixcharge Rate } & \multicolumn{2}{|l|}{ :200 H'sec } \\
\hline \multirow{2}{*}{\multicolumn{2}{|c|}{$\begin{array}{l}\text { Drill Shaft Mix No. } \\
\text { Truck Miver No. }\end{array}$}} & \multirow{2}{*}{\multicolumn{2}{|c|}{$\begin{array}{l}: 06-0281 \\
: 2969\end{array}$}} & \multicolumn{2}{|c|}{ Truck Slmp Gage } & \multicolumn{2}{|l|}{ N/A } \\
\hline & & & & \multicolumn{2}{|c|}{ Visul Shmp } & \multicolumn{2}{|l|}{ N/A } \\
\hline \multicolumn{2}{|c|}{ He adtroter } & $\begin{array}{l}: 2900 \\
.0000 \%\end{array}$ & & \multicolumn{2}{|l|}{ Loed Sim } & \multicolumn{2}{|l|}{ : 9 cuyds } \\
\hline \multicolumn{2}{|l|}{ Whath woter } & $: 1000 \%$ & & \multicolumn{2}{|c|}{ Mojing Speed } & \multicolumn{2}{|l|}{$12 \mathrm{Ipm}$} \\
\hline \multicolumn{8}{|c|}{ E 82 Butch Fecard } \\
\hline Materials & $\begin{array}{c}\text { Sourre- } \\
\text { Type }\end{array}$ & Mix Design & $\begin{array}{l}\text { Tr get } \\
\text { Weijitt }\end{array}$ & $\begin{array}{l}\text { Actural } \\
\text { Weigitit }\end{array}$ & Tolerences & $\begin{array}{l}\text { Auto ar } \\
\text { Manulal }\end{array}$ & $\begin{array}{l}\text { Moistare } \\
\text { Percent }\end{array}$ \\
\hline$\# 57$ & Rinker & $1 \not 567 \mathrm{bs}$ & $15,228 \mathbf{b}$ & $15,240 \mathrm{~b}$ & IN & Auto & $1.50 \%$ \\
\hline Sund & Ortane & $1053 \mathrm{bs}$ & 9,722 bs & 9,720 bs & IN & Auto & $2.60 \%$ \\
\hline Cemert & $\begin{array}{l}\text { Type II } \\
\text { Rinker }\end{array}$ & $298 \mathrm{bs}$ & 2,682 bs & 2,690 bs & IN & Auto & \\
\hline Slag & Rinker & 447 bs & 4 م2 bs & $4,030 \mathrm{bs}$ & IN & Auto & \\
\hline$A \dot{x}$ & $\begin{array}{l}\text { Derex } \\
\text { (Grece) }\end{array}$ & $20 x$ & 54 ox & $54 \mathrm{oz}$ & IN & Auto & \\
\hline Rater der & $\begin{array}{l}\text { WRDA } \\
64 \text {;Gnce }\end{array}$ & $80 \mathrm{oz}$ & 214 ox & $2150 x$ & IN & Auto & \\
\hline Wuter & WEll & 37 gal & $252 \mathrm{gel}$ & 251 gel & IN & Auto & \\
\hline \multicolumn{8}{|c|}{ 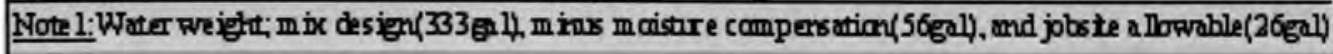 } \\
\hline \multicolumn{8}{|c|}{ E 83 Batch Carcrete Properties } \\
\hline & Slmep & $A \dot{x} \%$ & Tempenture & \multicolumn{2}{|c|}{ Unit wejeght Cyinder cost \& } & \multicolumn{2}{|c|}{$\begin{array}{c}\text { Cylinder cest } 8 \\
\mathbf{2 0} \text {-days }\end{array}$} \\
\hline Iruitial & $7.50 \mathrm{in}$ & H/A & $84 \mathrm{~F}$ & 142 & N/A & \multicolumn{2}{|c|}{ H/A } \\
\hline Frmal & $7.50 \mathrm{in}$ & $300 \%$ & $83 \mathrm{~F}$ & 140.8 & 2 & \multicolumn{2}{|c|}{3} \\
\hline \multicolumn{8}{|c|}{ E 8.4 Shmp Stand Date } \\
\hline & $\begin{array}{l}\text { Allowred } \\
\text { witer }\end{array}$ & $\begin{array}{l}\text { Viseul } \\
\text { slmp }\end{array}$ & $\begin{array}{l}\text { No. intial } \\
\text { rewolitims }\end{array}$ & $\begin{array}{l}\text { Wuter } \\
\text { ediled }\end{array}$ & $\begin{array}{l}\text { Additional } \\
\text { Ievolitions }\end{array}$ & \multirow{2}{*}{\multicolumn{2}{|c|}{$\begin{array}{c}\text { Totel Hrevolitions } \\
\text { \& dischrige } \\
80\end{array}$}} \\
\hline & 26 gal & N/A & 31 & $10 \mathrm{gel}$ & 49 & & \\
\hline \multicolumn{8}{|c|}{ Note 2: 120 tothlrevolitions, prior to complete dischnge of the miver. } \\
\hline \multicolumn{8}{|c|}{ E 85 Lumps Dischrrged } \\
\hline \begin{tabular}{|c|} 
Sime of \\
Bnls
\end{tabular} & $\begin{array}{l}3 \text { to } 4 \\
\text { (in) }\end{array}$ & $\begin{array}{l}5 \text { to } 6 \\
\text { (iin) }\end{array}$ & $\begin{array}{l}7 \text { to } 8 \\
\text { (in) }\end{array}$ & $\begin{array}{l}9 \text { to } 10 \\
\text { (in) }\end{array}$ & $\begin{array}{c}11 \text { to } 12 \\
\text { (in) }\end{array}$ & $\begin{array}{l}>12 \\
\text { (in) }\end{array}$ & $\begin{array}{c}\text { Total \# of } \\
\text { Bulk }\end{array}$ \\
\hline $\begin{array}{l}\text { Khmber } \\
\text { of Buls }\end{array}$ & 13 & 18 & 6 & 2 & 6 & 0 & 45 \\
\hline
\end{tabular}




\begin{tabular}{|c|c|c|c|c|c|c|c|}
\hline \multicolumn{8}{|c|}{ E9.1 Batch Dete } \\
\hline \multirow{5}{*}{\multicolumn{2}{|c|}{$\begin{array}{l}\text { Dete } \\
\text { Drill Shaft Mix No. } \\
\text { Truck Miver Ho. } \\
\text { He atwere } \\
\text { Whis witer } \\
\end{array}$}} & $: 5 n / 2001$ & & \multirow{2}{*}{\multicolumn{2}{|c|}{$\begin{array}{l}\text { Discherge Rate } \\
\text { Truck Slimp Gage }\end{array}$}} & \multicolumn{2}{|l|}{ : $200 \mathrm{H} / \mathrm{ec}$} \\
\hline & & $: 06-0281$ & & & & \multicolumn{2}{|l|}{ N/A } \\
\hline & & 2909 & & \multirow{2}{*}{\multicolumn{2}{|c|}{$\begin{array}{l}\text { Visual Shmp } \\
\text { Loed Sim }\end{array}$}} & \multirow{2}{*}{\multicolumn{2}{|c|}{$\begin{array}{l}: \text { H/A } \\
: 9 \text { cuyds }\end{array}$}} \\
\hline & & $981.009 \%$ & & & & & \\
\hline & & $: 1900 \%$ & & \multicolumn{2}{|l|}{ Moling Speed } & \multicolumn{2}{|l|}{$: 12 \mathrm{rmm}$} \\
\hline \multicolumn{8}{|c|}{ E 92 Butch Recond } \\
\hline Moterins & $\begin{array}{c}\begin{array}{c}\text { Sourre- } \\
\text { Type }\end{array} \\
\end{array}$ & Mix Design & $\begin{array}{l}\text { Triget } \\
\text { Whight }\end{array}$ & Actual Weight & Tolerences & $\begin{array}{l}\text { Auto ar } \\
\text { Monavel }\end{array}$ & $\begin{array}{l}\text { Moisture } \\
\text { Perceut }\end{array}$ \\
\hline$\# 57$ & Rinker & $1,667 \mathrm{bs}$ & $15,228 \mathbf{b}$ & $15,280 \mathbf{b}$ & IN & Aunto & $1.50 \%$ \\
\hline Sand & Ortone & $1053 \mathbf{b s}$ & 9,704 bs & $9,680 \mathrm{bs}$ & IN & Auto & $2.40 \%$ \\
\hline Cement & $\begin{array}{l}\text { Type II } \\
\text { Rinker }\end{array}$ & $298 \mathrm{bs}$ & 2,882 bs & $2,710 \mathrm{bs}$ & UUT & Auto & \\
\hline Slag & Rinker & 447 bs & $4 \mathrm{ma} \mathrm{bs}$ & $4,040 \mathrm{bs}$ & IN & Aun & \\
\hline$A \dot{I}$ & $\begin{array}{l}\text { Derex } \\
\text { (Grece) }\end{array}$ & $20 x$ & 54 ox & 54 or & IN & Auto & \\
\hline Retarder & $\begin{array}{c}\text { WRDA } \\
64 \text {; Crence }\end{array}$ & $80 x$ & 214 ox & $2150 x$ & IN & Auto & \\
\hline Witer & well & 37 gal & $226 \mathrm{gel}$ & 225 gl & IN & Autn & \\
\hline \multicolumn{8}{|c|}{ 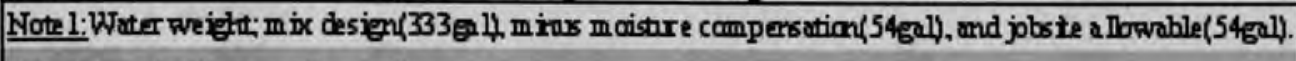 } \\
\hline \multicolumn{8}{|c|}{ E 93 Butch Courcrete Properties } \\
\hline & Slmp & $A \dot{x} \%$ & Temperture & $\begin{array}{l}\text { Unt weight } \\
\text { (\#ituft) }\end{array}$ & $\begin{array}{l}\text { Cylinder cest } \\
\text { Ofdays }\end{array}$ & \multicolumn{2}{|c|}{$\begin{array}{l}\text { Cylinder cest } \\
28 \text {-days }\end{array}$} \\
\hline $\begin{array}{l}\text { Iritial } \\
4 \mathrm{gel}\end{array}$ & $6.75 \mathrm{in}$ & N/A & B2F & N/A & N/A & \multicolumn{2}{|c|}{ W/A } \\
\hline $\begin{array}{l}\text { wuter } \\
\text { eddition }\end{array}$ & $7.25 \mathrm{in}$ & W/A & $82 \mathrm{~F}$ & N/A & N/A & \multicolumn{2}{|c|}{ N/A } \\
\hline Final & $7.75 \mathrm{in}$ & $225 \%$ & $82 \mathrm{~F}$ & 140.4 & 2 & \multicolumn{2}{|r|}{2} \\
\hline \multicolumn{8}{|c|}{ Note 2: Supplemertal4 gal witer adfition, meets shmp requiremarts. } \\
\hline \multicolumn{8}{|c|}{ E 9.4 Stump Stand Dote } \\
\hline \multirow{2}{*}{$\begin{array}{l}\text { Allowed } \\
\text { whter } \\
\text { S4 El }\end{array}$} & Visuel shmp & $\begin{array}{l}\text { No.intiel } \\
\text { revohtions }\end{array}$ & $\begin{array}{l}\text { Whter } \\
\text { additim }\end{array}$ & $\begin{array}{l}\text { Supplematal } \\
\text { water eddition }\end{array}$ & $\begin{array}{l}\text { Additimal } \\
\text { revoltitims }\end{array}$ & \multicolumn{2}{|c|}{$\begin{array}{c}\text { Total Hrewohtians } \\
\text { \& discharge }\end{array}$} \\
\hline & N/A & 40 & 7 gel & 4 gal & 43 & & 83 \\
\hline \multicolumn{8}{|c|}{ Wote 3: 181 tothlrevolutions, prior to complete discharge of the miver. } \\
\hline \multicolumn{8}{|c|}{ E95 Lumps Discharged } \\
\hline \begin{tabular}{|c|}
$\begin{array}{c}\text { Sime of } \\
\text { B.Is }\end{array}$ \\
\end{tabular} & \begin{tabular}{|c|}
3 to 4 \\
(in) \\
\end{tabular} & $\begin{array}{l}5 \text { to } 6 \\
\text { (iin) }\end{array}$ & $\begin{array}{l}7 \text { to } 8 \\
\text { (in) }\end{array}$ & $\begin{array}{l}9 \text { to } 10 \\
\text { (in) }\end{array}$ & $\begin{array}{l}11 \text { to } 12 \\
\text { (in) }\end{array}$ & $\begin{array}{l}>12 \\
\text { (in) }\end{array}$ & $\begin{array}{c}\text { Totel \# of } \\
\text { Bells }\end{array}$ \\
\hline \# of Blls & 2 & 3 & 3 & 0 & 0 & 1 & 9 \\
\hline
\end{tabular}




\begin{tabular}{|c|c|c|c|c|c|c|c|}
\hline \multicolumn{8}{|c|}{ E 10.1 Betch Dete } \\
\hline \multicolumn{2}{|c|}{ Dete } & \multicolumn{2}{|l|}{$: 5 n / 2001$} & \multicolumn{2}{|c|}{ Discharge Rate } & \multicolumn{2}{|l|}{$: 200$ Wsec } \\
\hline \multirow{2}{*}{\multicolumn{2}{|c|}{$\begin{array}{l}\text { Drin Shaft Mix Ko. } \\
\text { Truck Bdixcer No. }\end{array}$}} & \multirow{2}{*}{\multicolumn{2}{|c|}{$\begin{array}{l}06-0281 \\
2969\end{array}$}} & \multicolumn{2}{|c|}{ Truck Slmp Gege } & $\begin{array}{l}.200 \mathrm{Hsec} \\
\mathrm{N} / \mathrm{A}\end{array}$ & \\
\hline & & & & \multicolumn{2}{|c|}{ Visual Slmp } & \multicolumn{2}{|l|}{ N/A } \\
\hline \multicolumn{2}{|c|}{ He actwoter } & $\frac{78.00 \%}{: 22.00 \%}$ & & \multicolumn{2}{|l|}{$\begin{array}{l}\text { Loud Sime } \\
\text { Mfing Speed }\end{array}$} & \multicolumn{2}{|l|}{$\begin{array}{l}: 9 \text { cu yds } \\
: 12 \text { rpm }\end{array}$} \\
\hline \multicolumn{8}{|c|}{ E 102 Betch Recond } \\
\hline Materinls & $\begin{array}{l}\text { Sourre- } \\
\text { Type }\end{array}$ & Mix Design & $\begin{array}{l}\text { Tar get } \\
\text { Weightt }\end{array}$ & $\begin{array}{l}\text { Actual } \\
\text { Weight }\end{array}$ & Tolerences & $\begin{array}{l}\text { Auto ar } \\
\text { Manoul }\end{array}$ & $\begin{array}{l}\text { Moisture } \\
\text { Percert }\end{array}$ \\
\hline$\# 57$ & Rinker & $1 \not 667 \mathrm{bs}$ & $15,288 \mathrm{~b}$ & $15,240 \mathrm{~b}$ & II & Auto & $1.50 \%$ \\
\hline Sund & Ortane & $1053 \mathbf{~ b s}$ & 9,704 bs & 9,600 bs & IN & Auto & $2.40 \%$ \\
\hline Cemert & $\begin{array}{l}\text { Type II } \\
\text { Rinker }\end{array}$ & 298 bs & 2,682 bs & 2,700 bs & IN & Auto & \\
\hline Slag & Rinker & 447 bs & $4,022 \mathrm{bs}$ & $4,030 \mathrm{bs}$ & IN & Auto & \\
\hline Air & $\begin{array}{l}\text { Darex } \\
\text { (Grece) }\end{array}$ & $20 x$ & $54 \mathrm{oz}$ & $530 \mathrm{z}$ & IN & Auto & \\
\hline Reterder & $\begin{array}{l}\text { WIRDÁ } \\
64 \text {; Crence }\end{array}$ & $80 x$ & 214 ox & 214 ox & IN & Auto & \\
\hline Witer & Well & 37 gal & $218 \mathrm{gl}$ & $217 \mathrm{pl}$ & IN & Auto & \\
\hline \multicolumn{8}{|c|}{ 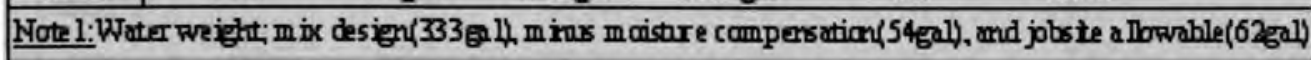 } \\
\hline \multicolumn{8}{|c|}{ E 103 Berth Concrete Properties } \\
\hline & Shmp & $A \dot{x} \%$ & Tempenture & \multicolumn{2}{|c|}{$\begin{array}{l}\text { Uni weight Cyinder cost Q } \\
\text { (H/cu ft) } 7 \text {-days }\end{array}$} & \multicolumn{2}{|c|}{$\begin{array}{c}\text { Cylinder cest } \\
\boldsymbol{x B} \text {-doys }\end{array}$} \\
\hline Initiel & $8.25 \mathrm{in}$ & N/A & $82 \mathrm{~F}$ & N/A & H/A & \multicolumn{2}{|c|}{ W/A } \\
\hline Final & $8.75 \mathrm{in}$ & $250 \%$ & N/A & 140 & 2 & \multicolumn{2}{|c|}{2} \\
\hline \multicolumn{8}{|c|}{ E 10.4 Shmp Stand Dote } \\
\hline & $\begin{array}{l}\text { Allowed } \\
\text { witer } \\
62 \mathrm{ez}\end{array}$ & $\begin{array}{c}\text { Vigen } \\
\text { slmp } \\
\text { N/A }\end{array}$ & $\begin{array}{c}\text { No.intiel } \\
\text { revolitions } \\
35\end{array}$ & $\begin{array}{l}\text { Wuer } \\
\text { edded } \\
9 \text { ell }\end{array}$ & $\begin{array}{l}\text { Additionel } \\
\text { revolitions } \\
50\end{array}$ & \multicolumn{2}{|c|}{$\begin{array}{c}\text { Total \#revolitims } \\
\text { Q discharge } \\
85\end{array}$} \\
\hline \multicolumn{8}{|c|}{ Wote: 181 totalrevoltims, priar to complete dischurge of the mixur. } \\
\hline \multicolumn{8}{|c|}{ E 10 S Lumps Dixharged } \\
\hline $\begin{array}{c}\text { Sime of } \\
\text { BIIs }\end{array}$ & $\begin{array}{c}3 \text { to } 4 \\
\text { (in) }\end{array}$ & $\begin{array}{l}5 \text { to } 6 \\
\text { (iin) }\end{array}$ & $\begin{array}{l}7 \text { to } 8 \\
\text { (in) }\end{array}$ & $\begin{array}{l}9 \text { to } 10 \\
\text { (im) }\end{array}$ & $\begin{array}{l}11 \text { to } 12 \\
\text { (in) }\end{array}$ & $\begin{array}{l}>12 \\
\text { (in) }\end{array}$ & $\begin{array}{c}\text { Total \# f } \\
\text { Bells }\end{array}$ \\
\hline $\begin{array}{l}\text { Kumber } \\
\text { of Bells }\end{array}$ & 13 & 17 & 6 & 2 & 2 & 4 & $\$ 4$ \\
\hline
\end{tabular}


E 11 Test Butch Al 1; He ad Whter

\begin{tabular}{|c|c|c|c|c|c|c|c|}
\hline \multicolumn{8}{|c|}{ 6.11.1 Butch Dete } \\
\hline$\overline{\text { Dete }}$ & & \multicolumn{2}{|l|}{$: 5 / 7 / 2001$} & \multicolumn{2}{|c|}{ Discharge Rate } & \multicolumn{2}{|l|}{$: 200$ W/sec } \\
\hline \multicolumn{2}{|c|}{ Drill Shaft Mix Ho. } & \multirow{2}{*}{\multicolumn{2}{|c|}{2900}} & \multicolumn{2}{|c|}{ Truck Shmp Gege } & \multicolumn{2}{|l|}{ N/A } \\
\hline \multicolumn{2}{|c|}{ Truck Hower Ho. } & & & \multicolumn{2}{|c|}{ Visuel Slmp } & \multicolumn{2}{|l|}{ W/A } \\
\hline \multicolumn{2}{|c|}{$\begin{array}{l}\text { He adwuter } \\
\text { Whish witer }\end{array}$} & \multicolumn{2}{|l|}{$\frac{: 08.00 \%}{: 32.00 \%}$} & \multicolumn{2}{|c|}{$\begin{array}{l}\text { Lood Sime } \\
\text { Moning Speed }\end{array}$} & \multicolumn{2}{|l|}{$\begin{array}{l}: 9 \text { cu yds } \\
: 12 \text { rpm }\end{array}$} \\
\hline \multicolumn{8}{|c|}{ E 112 Batch Recard } \\
\hline Materinls & $\begin{array}{l}\text { Sorrte- } \\
\text { Type }\end{array}$ & Mix Design & $\begin{array}{l}\text { Triget } \\
\text { Whijgtt } \\
\end{array}$ & $\begin{array}{l}\text { Actual } \\
\text { Whight }\end{array}$ & Tolerences & $\begin{array}{l}\text { Auto or } \\
\text { Manuelel }\end{array}$ & $\begin{array}{c}\text { Mbisture } \\
\text { Percent }\end{array}$ \\
\hline$\# 57$ & Rinker & $1567 \mathrm{hs}$ & $15,228 \mathrm{~b}$ & $15,240 \mathrm{~b}$ & IN & Auto & $1.50 \%$ \\
\hline Sand & Ortme & $1053 \mathbf{b s}$ & 9,704 bs & $9,720 \mathrm{bs}$ & IN & Anto & $2.40 \%$ \\
\hline Cemert & $\begin{array}{l}\text { Type II } \\
\text { Rinker }\end{array}$ & $298 \mathrm{bs}$ & 2,582 bs & 2,700 bs & IN & Auto & \\
\hline Slag & Rinker & 447 bs & 4,020 bs & 4 p10 bs & IN & Anto & \\
\hline Air & $\begin{array}{l}\text { Derex } \\
\text { (Grace) }\end{array}$ & $20 x$ & $54 \mathrm{oz}$ & $53 \mathrm{oz}$ & IN & Auto & \\
\hline Ratarder & $\begin{array}{l}\text { WRDA } \\
64 \text {;Chese }\end{array}$ & $80 x$ & $2140 x$ & 214 ox & IN & Auto & \\
\hline What & well & 37 gol & 190 gel & 189 al & IN & Auto & \\
\hline \multicolumn{8}{|c|}{ 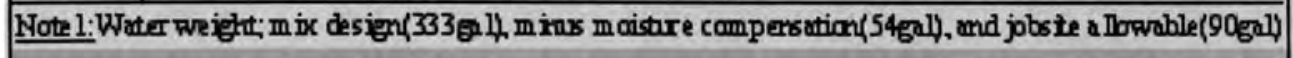 } \\
\hline \multicolumn{8}{|c|}{ E 113 Btrh Comate Properties } \\
\hline & Slmp & $\mathrm{A} \dot{\mathbf{r}} \%$ & Tempentare & \multicolumn{2}{|c|}{ 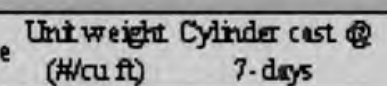 } & \multicolumn{2}{|c|}{$\begin{array}{l}\text { Cylinder cest } \\
23 \text {-doys }\end{array}$} \\
\hline Iruitial & $80 \mathrm{in}$ & N/A & $82 \mathrm{~F}$ & N/A & H/A & \multicolumn{2}{|c|}{ H/A } \\
\hline Fmal & $7.75 \mathrm{in}$ & $200 \%$ & N/A & 141.2 & 2 & \multicolumn{2}{|c|}{2} \\
\hline \multicolumn{8}{|c|}{ E 11.4 Shump Stand Dete } \\
\hline & $\begin{array}{l}\text { Allowred } \\
\text { witer }\end{array}$ & $\begin{array}{l}\text { Visul } \\
\text { slmp }\end{array}$ & $\begin{array}{l}\text { No.intial } \\
\text { rewolitims }\end{array}$ & $\begin{array}{l}\text { Witer } \\
\text { edded }\end{array}$ & $\begin{array}{l}\text { Additimal } \\
\text { revoltitims }\end{array}$ & \multirow{2}{*}{\multicolumn{2}{|c|}{$\begin{array}{c}\text { Totel Hrevolitions } \\
8 \text { discharge } \\
92\end{array}$}} \\
\hline & 62 gel & N/A & 35 & 40 gal & 57 & & \\
\hline \multicolumn{8}{|c|}{ Hote 2: 181 tothlrevolitims, prior to complate discharge of the miver. } \\
\hline \multicolumn{8}{|c|}{ E 115 Lumps Discharged } \\
\hline \begin{tabular}{|c|c|} 
Sime of \\
Bulk
\end{tabular} & $\begin{array}{c}3 \text { to } 4 \\
\text { (in) }\end{array}$ & $\begin{array}{c}5 \text { to } 6 \\
\text { (iii) }\end{array}$ & $\begin{array}{l}7 \text { to } 8 \\
\text { (in) }\end{array}$ & $\begin{array}{l}9 \text { to } 10 \\
\text { (iin) }\end{array}$ & $\begin{array}{l}11 \text { to } 12 \\
\text { (in) }\end{array}$ & $\begin{array}{l}>12 \\
\text { (in) }\end{array}$ & $\begin{array}{c}\text { Total \# of } \\
\text { Bulls }\end{array}$ \\
\hline $\begin{array}{l}\text { Finnber } \\
\text { of Balls }\end{array}$ & 3 & 1 & 1 & 0 & 0 & 0 & 5 \\
\hline
\end{tabular}


E 12 Test Butch H12; He ad Whter

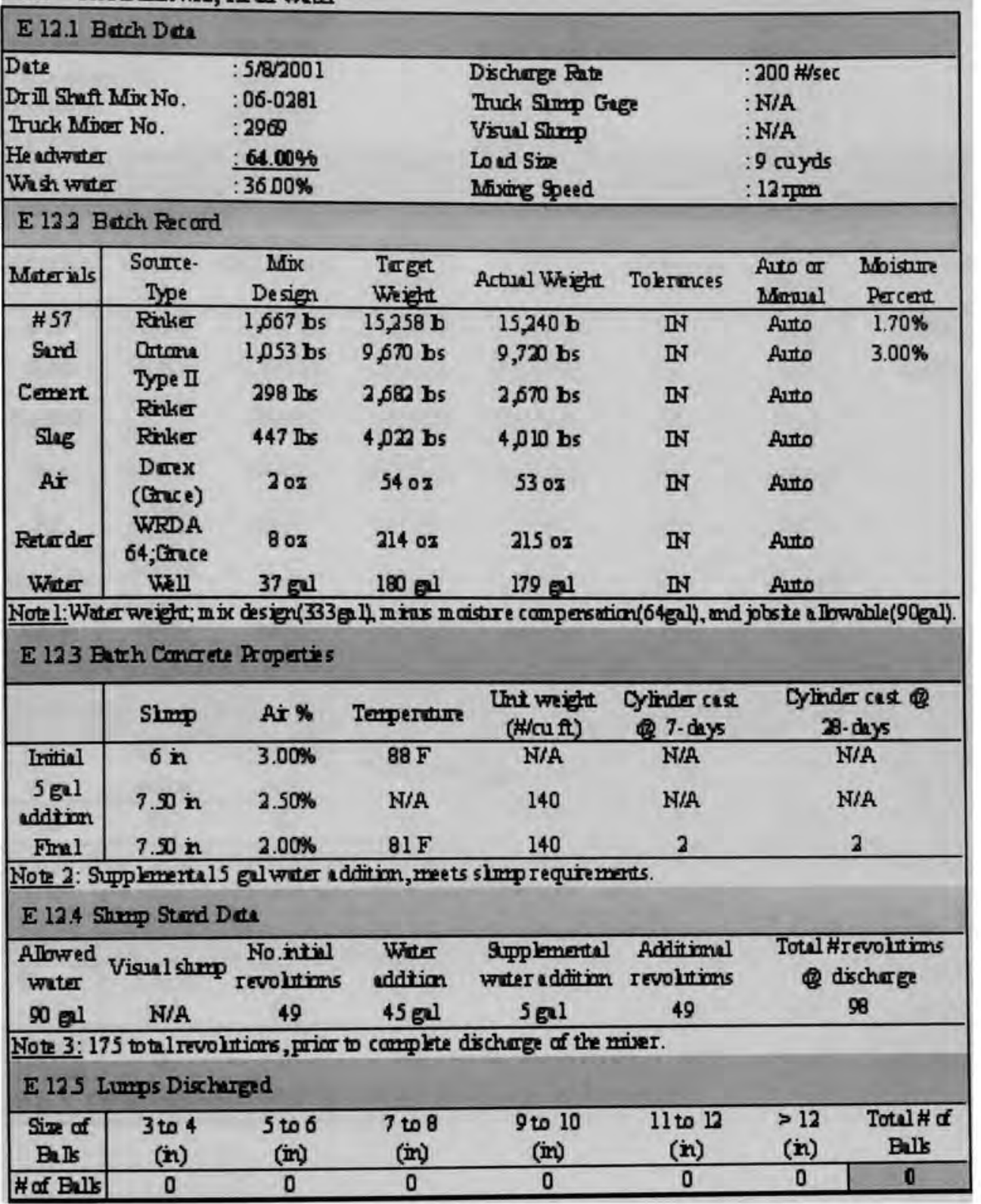


E 13 Test Batch H1; He ed Whter

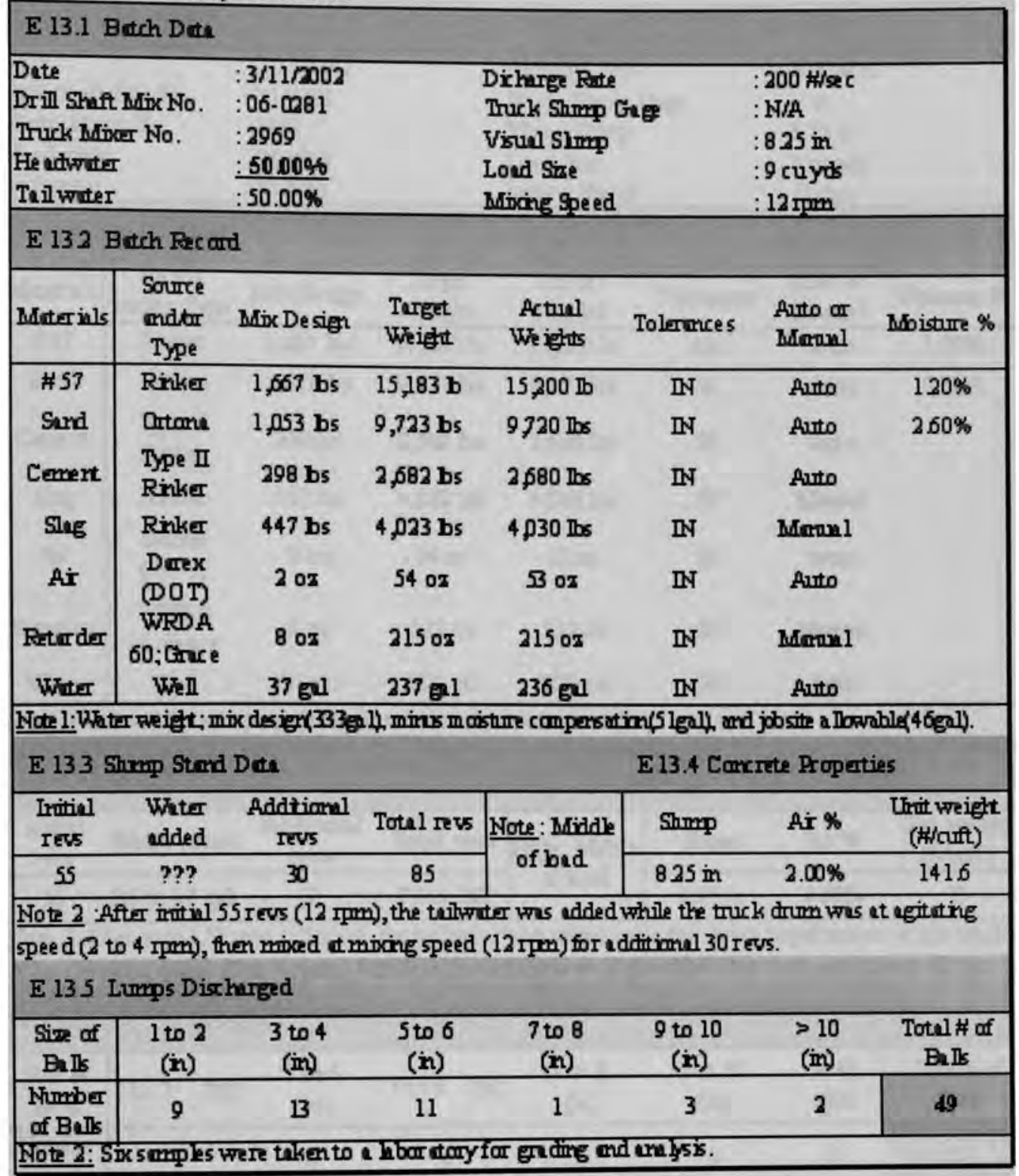


E 14 Test Batch 地; He ed Whter OF PHASE I

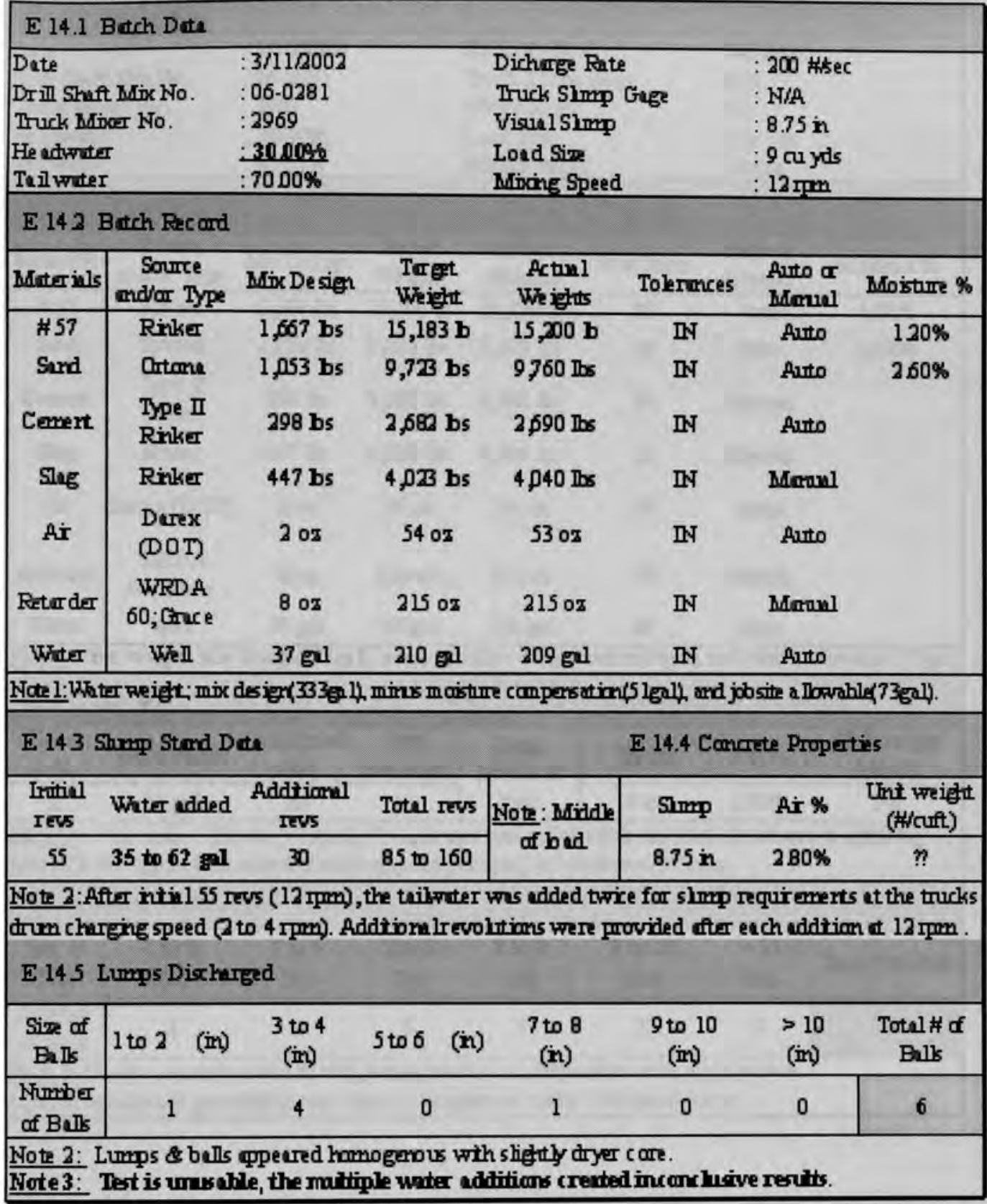


E 15 Test Butch \#3; Heed Whter of Phase II

\begin{tabular}{|c|c|c|c|c|c|c|c|}
\hline \multirow{4}{*}{\multicolumn{2}{|c|}{$\begin{array}{l}\text { Dete } \\
\text { Drill Shaft Mix No. } \\
\text { Truck Majoer No. } \\
\text { He actwiter } \\
\text { Tuilwuter }\end{array}$}} & \multirow{2}{*}{\multicolumn{2}{|c|}{$\begin{array}{l}: 3 / 12 / 2002 \\
: 06-0281\end{array}$}} & \multirow{3}{*}{\multicolumn{2}{|c|}{$\begin{array}{l}\text { Dirharge Rate } \\
\text { Thuck Slmp Guge } \\
\text { Visual Slmp }\end{array}$}} & \multicolumn{2}{|l|}{$: 200 \mathrm{H} / \mathrm{sec}$} \\
\hline & & & & & & : W/A & \\
\hline & & $: 2900$ & & & & $: 9 \mathrm{n}$ & \\
\hline & & $\frac{20.000 \%}{: 80.00 \%}$ & & \multicolumn{2}{|c|}{$\begin{array}{l}\text { Lood Size } \\
\text { Mbixing Speed }\end{array}$} & $\begin{array}{l}: 9 \mathrm{cu} \text { yds } \\
: 12 \mathrm{rm}\end{array}$ & \\
\hline \multicolumn{8}{|c|}{ E 152 Batch Aec ard } \\
\hline Moterinls & $\begin{array}{c}\text { Sourre } \\
\text { and/ar Type }\end{array}$ & Mix Design & $\begin{array}{l}\text { Terget } \\
\text { Wh ight }\end{array}$ & $\begin{array}{l}\text { Actural } \\
\text { Whigints }\end{array}$ & Tolerences & $\begin{array}{l}\text { Auto a } \\
\text { Menuel }\end{array}$ & Mositame \% \\
\hline$\# 57$ & Rinker & $1567 \mathrm{IbS}$ & $15,288 \mathrm{~b}$ & $15,280 \mathbf{b}$ & IN & Auto & $1.90 \%$ \\
\hline Sund & Ortme & $1,53 \mathrm{Ibs}$ & $9,723 \mathrm{bs}$ & 9,720 bs & IN & Auto & $2.60 \%$ \\
\hline Cenert & $\begin{array}{l}\text { Type II } \\
\text { Rinker }\end{array}$ & $298 \mathrm{bs}$ & $2 \not 582 \mathrm{bs}$ & 2,590 bs & IN & Manal & \\
\hline Slag & Rinker & $447 \mathrm{bs}$ & $4 \rho 23 \mathrm{bs}$ & 4,090 bs & IN & Manul & \\
\hline Ai & Dere $x(D O T)$ & $20 x$ & 54 or & 54 ox & IN & Auto & \\
\hline Futarder & $\begin{array}{l}\text { WRDA } \\
60 \text {; Gree }\end{array}$ & $80 z$ & $214 \mathrm{oz}$ & 215 ox & IN & Mennual & \\
\hline Wuter & well & 37 gal & $197 \mathrm{gal}$ & $196 \mathrm{gl}$ & IN & Auto & \\
\hline \multicolumn{8}{|c|}{ 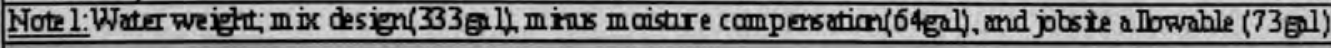 } \\
\hline \multicolumn{4}{|c|}{ E 153 Shmp Stend Dite } & \multicolumn{4}{|c|}{ E 15.4 Concte Properies } \\
\hline $\begin{array}{l}\text { Iritial } \\
\text { rews }\end{array}$ & Whter added & $\begin{array}{l}\text { Additional } \\
\text { revs }\end{array}$ & $\begin{array}{c}\text { Total } \\
\text { revolitimn } \\
\end{array}$ & \multirow{2}{*}{\begin{tabular}{|l|} 
Mote: \\
loed
\end{tabular}} & Slimp & Air \% & $\begin{array}{l}\text { Unt wreiglt } \\
\text { (Hituft) }\end{array}$ \\
\hline 55 & 56 gäl & 30 & 85 & & 9 in & $280 \%$ & 141 \\
\hline \multicolumn{8}{|c|}{ 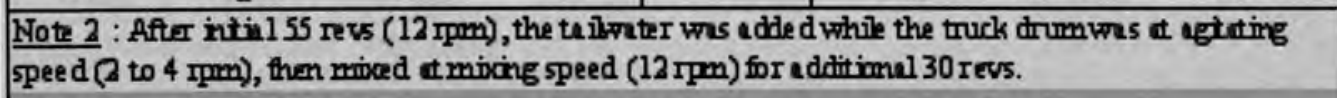 } \\
\hline \multicolumn{8}{|c|}{ E 155 Iumps Discharged } \\
\hline $\begin{array}{l}\text { Sime of } \\
\text { Buls }\end{array}$ & $\begin{array}{l}1 \text { to } 2 \\
\text { (in) }\end{array}$ & $\begin{array}{l}3 \text { to } 4 \\
\text { (in) }\end{array}$ & $\begin{array}{l}5 \text { to } 6 \\
\text { (in) }\end{array}$ & $\begin{array}{l}7 \text { to } 8 \\
\text { (in) }\end{array}$ & $\begin{array}{l}9 \text { to } 10 \\
\text { (in) }\end{array}$ & $\begin{array}{l}>10 \\
\text { (im) }\end{array}$ & Total \# of Buls \\
\hline \begin{tabular}{|l|} 
Kinmber \\
of Bells
\end{tabular} & 3 & 3 & 3 & 0 & 0 & 1 & 10 \\
\hline
\end{tabular}


E 16 Test Butch \#; Iritill Revoltions (30\% Heed Witer) of Phase II

\begin{tabular}{|c|c|c|c|c|c|c|c|}
\hline \multicolumn{8}{|c|}{ E 16.1 Betch Deth } \\
\hline \multicolumn{2}{|c|}{ Dete } & \multicolumn{2}{|l|}{$: 3 / 2 / 2002$} & \multicolumn{2}{|c|}{ Dirharge Rute } & :200 Hsec & \\
\hline \multicolumn{2}{|c|}{$\begin{array}{l}\text { Drill Shaft Mixix Ho. } \\
\text { Truck Maiker No. }\end{array}$} & \multicolumn{2}{|l|}{$\begin{array}{l}: 06-0281 \\
: 2900\end{array}$} & \multicolumn{2}{|c|}{ Truck Shmp Gege } & W/A & \\
\hline \multicolumn{2}{|c|}{$\begin{array}{l}\text { He edwoter } \\
\text { Teilwer } \\
\end{array}$} & $\begin{array}{l}: 3000 \% \\
: 7000 \% \\
\end{array}$ & & \multicolumn{2}{|c|}{$\begin{array}{l}\text { Loed Sise } \\
\text { Miscing Speed }\end{array}$} & $\begin{array}{l}: 8.75 \text { in } \\
: 9 \text { cu yds } \\
: 12 \text { rm }\end{array}$ & \\
\hline \multicolumn{8}{|c|}{ E 162 Batch Rec ard } \\
\hline Moterinls & $\begin{array}{c}\text { Sourre } \\
\text { ond/ar } \\
\text { Type }\end{array}$ & Mix Design & $\begin{array}{l}\text { Target. } \\
\text { we jight }\end{array}$ & $\begin{array}{l}\text { Actual } \\
\text { Weights }\end{array}$ & Toler ences & $\begin{array}{l}\text { Auto or } \\
\text { Mormal }\end{array}$ & Moistare \% \\
\hline$\# 57$ & Rinler & $1667 \mathrm{Ibs}$ & $15,288 \mathbf{b}$ & $15,320 \mathrm{~b}$ & II & Auto & $1.90 \%$ \\
\hline Sand & Ortana & $1,053 \mathrm{Ibs}$ & $9,723 \mathrm{bs}$ & $9800 \mathrm{Ibs}$ & IN & Auto & $2.60 \%$ \\
\hline Cemert & $\begin{array}{l}\text { Type II } \\
\text { Rinker }\end{array}$ & $298 \mathrm{bs}$ & 2 582 bs & $2 \not 80$ Ibs & IN & Auto & \\
\hline Slag & Rinker & $447 \mathrm{bs}$ & $4 \rho 23 \mathrm{bs}$ & $4 \rho 00 \mathrm{Ibs}$ & IN & Monural & \\
\hline$A \dot{r}$ & $\begin{array}{r}\text { Durex } \\
\text { (DOT) }\end{array}$ & $20 x$ & $54 \mathrm{oz}$ & 53 ox & రUT & Monomel & \\
\hline Retarder & $\begin{array}{l}\text { WRDA } \\
60 \text {; Chere }\end{array}$ & $80 x$ & 214 ox & $2150 x$ & IN & Mnoul & \\
\hline Water & WeIl & 37 al & 197 gal & $196 \mathrm{gul}$ & II & Auto & \\
\hline \multicolumn{8}{|c|}{ 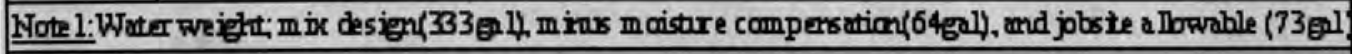 } \\
\hline \multicolumn{4}{|c|}{ E 163 Shmp Stand Dote } & \multicolumn{4}{|c|}{ E 16.4 Corrente Properties } \\
\hline $\begin{array}{l}\text { Initial } \\
\text { rews }\end{array}$ & $\begin{array}{l}\text { Wuter } \\
\text { edded }\end{array}$ & $\begin{array}{l}\text { Additimal } \\
\text { Iews }\end{array}$ & Totel rews & \multirow{2}{*}{$\begin{array}{l}\text { Wote: } \\
\text { Middle of } \\
\text { bed. }\end{array}$} & Slmm & Air \% & $\begin{array}{l}\text { Unit weight } \\
\text { (Hficut) }\end{array}$ \\
\hline \% & 55 gal & 30 & 105 & & $8.75 \mathrm{in}$ & $2.60 \%$ & 140.6 \\
\hline \multirow{2}{*}{\multicolumn{8}{|c|}{$\begin{array}{l}\text { Hote } 2 \text { : After intinl } 75 \text { revs (12 } \\
\text { speed (2 to } 4 \text { rpm), then mived } \\
\text { E 16.5 Lumps Discherged }\end{array}$}} \\
\hline & & & & & & & \\
\hline \begin{tabular}{|c|} 
Sive of \\
Bulls
\end{tabular} & $\begin{array}{l}1 \text { to } 2 \\
\text { (in) }\end{array}$ & $\begin{array}{l}3 \text { to } 4 \\
\text { (in) }\end{array}$ & $\begin{array}{l}5 \text { to } 6 \\
\text { (in) }\end{array}$ & $\begin{array}{l}7 \text { to } 8 \\
\text { (in) }\end{array}$ & $\begin{array}{l}9 \text { to } 10 \\
\text { (im) }\end{array}$ & $\begin{array}{l}>10 \\
\text { (in) }\end{array}$ & $\begin{array}{c}\text { Total \# of } \\
\text { Bulls }\end{array}$ \\
\hline \begin{tabular}{|c|} 
Fumber of \\
Buls
\end{tabular} & 0 & 1 & 2 & 2 & 2 & 0 & 7 \\
\hline
\end{tabular}


E 17 Test Butch th; Intial Navohtims (30\% Head Wtr) of Phose II

\begin{tabular}{|c|c|c|c|c|c|c|c|}
\hline \multicolumn{2}{|c|}{ Date } & \multicolumn{2}{|l|}{$: 3 / 12 / 2002$} & \multicolumn{2}{|c|}{ Dichrrg Rate } & \multicolumn{2}{|l|}{$: 200 \mathrm{H} / \mathrm{sec}$} \\
\hline \multirow{2}{*}{\multicolumn{2}{|c|}{$\begin{array}{l}\text { Drill Shaft Mix No. } \\
\text { Truck Miver No. }\end{array}$}} & \multirow{2}{*}{\multicolumn{2}{|c|}{$\begin{array}{l}: 05-0281 \\
: 2969\end{array}$}} & \multirow{2}{*}{\multicolumn{2}{|c|}{$\begin{array}{l}\text { Truck Shmp Gege } \\
\text { Visual Shmp }\end{array}$}} & \multicolumn{2}{|l|}{ N/A } \\
\hline & & & & \multirow{2}{*}{\multicolumn{2}{|c|}{$\begin{array}{l}\text { Lo ad Size } \\
\text { Mfixing Speed }\end{array}$}} & \multirow{2}{*}{\multicolumn{2}{|c|}{$\begin{array}{l}: 9 \text { cuyds } \\
: 12 \text { ram }\end{array}$}} \\
\hline \multicolumn{2}{|c|}{$\begin{array}{l}\text { He adwuter } \\
\text { Teil wuter }\end{array}$} & $70.00 \%$ & & & & & \\
\hline \multicolumn{8}{|c|}{ E 172 Bitch Recard } \\
\hline Materils & $\begin{array}{c}\text { Sourne } \\
\text { and/or } \\
\text { Type }\end{array}$ & Mix Design & $\begin{array}{l}\text { Torget. } \\
\text { Whight }\end{array}$ & $\begin{array}{l}\text { Actural } \\
\text { Weigits }\end{array}$ & Tolerences & $\begin{array}{l}\text { Auto ar } \\
\text { Marual }\end{array}$ & Mbisture \% \\
\hline$\# 57$ & Rirker & $1,567 \mathrm{bs}$ & $15,288 \mathrm{~b}$ & $15,280 \mathrm{~b}$ & IN & Anto & $190 \%$ \\
\hline Sund & Ortan & $1053 \mathrm{bs}$ & $9,723 \mathrm{bs}$ & $9,720 \mathrm{bs}$ & IN & Anto & $260 \%$ \\
\hline Cemert & $\begin{array}{l}\text { Type II } \\
\text { Rinker }\end{array}$ & 298 bs & 2,682 bs & $2 \$ 70 \mathrm{bs}$ & IN & 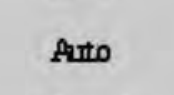 & \\
\hline Slag & Rirker & 447 bs & $4,023 \mathrm{bs}$ & $39,90 \mathrm{bs}$ & IN & Marual & \\
\hline $\mathrm{A} \dot{\mathbf{I}}$ & $\begin{array}{l}\text { Derex } \\
\text { (DOT) }\end{array}$ & $20 x$ & 54 ox & 53 oz & IN & Anto & \\
\hline Retarder & $\begin{array}{l}\text { WRDA } \\
\text { 60;Ctace }\end{array}$ & 802 & $214 \mathrm{oz}$ & $215 \mathrm{oz}$ & IN & Marual & \\
\hline Witer & whIl & 37 ol & 197 al & $197 \mathrm{gel}$ & IN & Anto & \\
\hline \multicolumn{8}{|c|}{ Note 1:Water weight; mix design (333 gall, minus moistre compersation(64gal), and jobste a Ibwable (72gal) } \\
\hline \multicolumn{4}{|c|}{ E 173 Shmp Stand Dote } & \multicolumn{4}{|c|}{ E 17.4 Carcrete Properties } \\
\hline $\begin{array}{l}\text { Iruitial } \\
\text { rews }\end{array}$ & $\begin{array}{l}\text { Witer } \\
\text { ediled }\end{array}$ & $\begin{array}{l}\text { Additional } \\
\text { revs }\end{array}$ & Total rews & \multirow{2}{*}{$\begin{array}{l}\text { Note: } \\
\text { Middle of } \\
\text { bed. }\end{array}$} & Slmp & $A \dot{r} \%$ & $\begin{array}{l}\text { Unit we igit: } \\
\text { (H/forf) }\end{array}$ \\
\hline 100 & 58 gal & 30 & 130 & & $850 \mathrm{in}$ & $2.50 \%$ & 141.4 \\
\hline \multicolumn{8}{|c|}{ 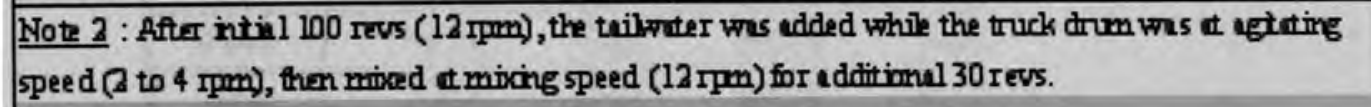 } \\
\hline \multicolumn{8}{|c|}{ E 175 Lumps Discharged } \\
\hline $\begin{array}{l}\text { Sime of } \\
\text { Brls }\end{array}$ & 1 to 2 (in) & 3 to 4 & 5 to 6 (im) & 7 to 8 (in) & $\begin{array}{l}9 \text { to } 10 \\
\text { (in) }\end{array}$ & $>10($ in) & $\begin{array}{l}\text { Totell of } \\
\text { Buls }\end{array}$ \\
\hline $\begin{array}{l}\text { Number } \\
\text { of Bulls }\end{array}$ & 0 & 0 & 0 & 0 & 0 & 0 & 0 \\
\hline
\end{tabular}




\section{CONCRETE BALL GRADATONS}

\begin{tabular}{cc} 
Tech. & BB \\
\hline Date & $4 / 18 / 2001$
\end{tabular}

INIT. WT. 4512.9

\begin{tabular}{|c|r|r|r|r|}
\hline SIEVE & WT. & \%ret. & \% cum. & \%pass \\
\hline $11 / 2^{\prime \prime}$ & 0.0 & 0.0 & 0.0 & 100.0 \\
\hline $1 "$ & 0.0 & 0.0 & 0.0 & 100.0 \\
\hline $3 / 4^{\prime \prime}$ & 357.0 & 7.9 & -7.9 & 92.1 \\
\hline $1 / 2^{\prime \prime}$ & 985.0 & 21.8 & 29.7 & 70.3 \\
\hline $3 / 8^{\prime \prime}$ & 589.0 & 13.1 & 42.8 & 57.2 \\
\hline$\# 4$ & 342.0 & 7.6 & $\cdot 50.4$ & 49.6 \\
\hline$\# 8$ & 35.0 & 0.8 & $\cdot 51.1$ & 48.9 \\
\hline$\# 10$ & 9.6 & 0.2 & 51.4 & 48.6 \\
\hline$\# 16$ & 118.6 & 2.6 & $\cdot 54.0$ & 46.0 \\
\hline$\# 30$ & 1026.0 & 22.7 & -76.7 & 23.3 \\
\hline$\# 40$ & 479.1 & 10.6 & 87.3 & 12.7 \\
\hline$\# 50$ & 226.4 & 5.0 & -92.4 & 7.6 \\
\hline$\# 80$ & 251.4 & 5.6 & 97.9 & 2.1 \\
\hline$\# 100$ & 41.2 & 0.9 & -98.8 & 1.2 \\
\hline$\# 200$ & 40.0 & 0.9 & 99.7 & 0.3 \\
\hline pan & 10.0 & 0.2 & 99.9 & 0.1 \\
\hline Total & 4510.3 & 99.9 & & \\
\cline { 1 - 3 } & & & &
\end{tabular}


Init Wt. g $1079.5 \quad \begin{gathered}\text { Ball Wt. g. before wash } \\ \text { Dry Wt after wash }\end{gathered} \frac{2975.0}{1079.5}$

\begin{tabular}{|c|c|c|c|c|c|c|}
\hline sieve & WT. & ind \%ret & cum\%ret & cum \% pass & \multirow{6}{*}{ Gilson pan wt. } & \multirow[b]{4}{*}{442.5} \\
\hline $1 "$ & 0.0 & 0.0 & 0.0 & 100.0 & & \\
\hline $3 / 4^{n}$ & 90.5 & 8.4 & 8.4 & 91.6 & & \\
\hline $1 / 2^{\prime \prime}$ & 242.0 & 22.4 & 30.8 & 69.2 & & \\
\hline $3 / 8^{\circ}$ & 114.0 & 10.6 & 41.4 & 58.6 & & \\
\hline \#4 & 158.5 & 14.7 & 56.0 & 44.0 & & 442.5 \\
\hline$\# 8$ & 28.0 & 2.6 & 58.6 & 41.4 & wt & factor \\
\hline$\# 10$ & 3.3 & 0.3 & 58.9 & 41.1 & 3.30 & 0.01 \\
\hline$\# 16$ & 28.6 & 2.6 & 61.6 & 38.4 & 28.60 & 0.06 \\
\hline$\# 30$ & 215.4 & 20.0 & 81.5 & 18.5 & 215.40 & 0.49 \\
\hline$\# 40$ & 86.9 & 8.1 & 89.6 & 10.4 & 86.90 & 0.20 \\
\hline$\# 50$ & 43.7 & 4.0 & 93.6 & 6.4 & 43.70 & 0.10 \\
\hline$\# 80$ & 39.8 & 3.7 & 97.3 & 2.7 & 39.80 & 0.09 \\
\hline$\# 100$ & 9.4 & 0.9 & 98.2 & 1.8 & 9.40 & 0.02 \\
\hline$\# 200$ & 10.4 & 1.0 & 99.2 & 0.8 & 10.40 & 0.02 \\
\hline pan & 4.6 & 0.4 & 99.6 & 0.4 & 4.60 & 0.01 \\
\hline Total & 1075.1 & 99.6 & 99.6 & & 442.10 & 1.00 \\
\hline
\end{tabular}

Init W: $\mathrm{g}$

Ball Wt. $g$ before wash

Dry Wt. after wash

2975

1981.5

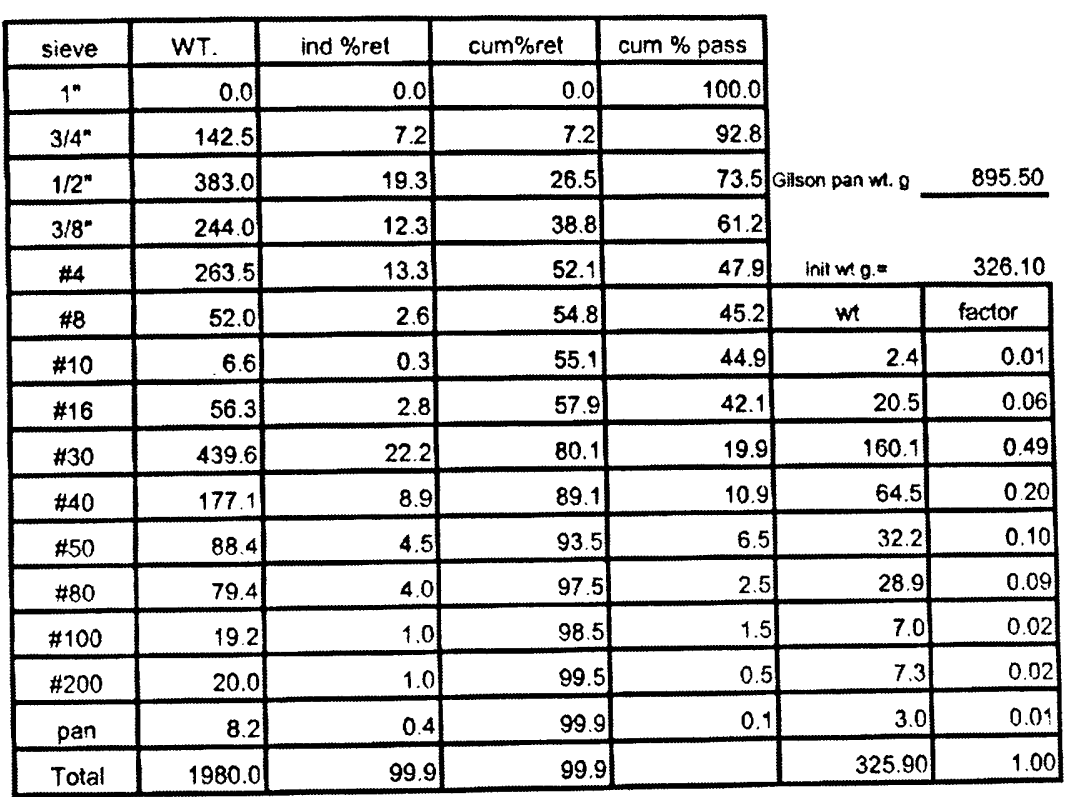


Init Wt. g 5596.0

Ball Wt. g before wash

Dry Wt. after wash

8307.0

\begin{tabular}{|c|c|c|c|c|c|c|}
\hline sieve & WT. & ind \%ret & cum\%ret & cum $\%$ pass & \multirow{6}{*}{ Gilson pan wt. g } & \multirow[b]{4}{*}{3114.0} \\
\hline $1^{n}$ & 42.0 & 0.8 & 0.0 & 100.0 & & \\
\hline $3 / 4^{\prime \prime}$ & 192.0 & 3.4 & 3.4 & 96.6 & & \\
\hline $1 / 2^{n}$ & 811.0 & 14.5 & 17.9 & 82.1 & & \\
\hline $3 / 8^{\prime \prime}$ & 552.5 & 9.9 & 27.8 & 72.2 & & \\
\hline$\# 4$ & 718.0 & 12.8 & 40.6 & 59.4 & & 318.10 \\
\hline$\# 8$ & 151.5 & 2.7 & 43.3 & 56.7 & $w t$ & factor \\
\hline$\# 10$ & 15.7 & 0.3 & 43.6 & 56.4 & 1.6 & 0.01 \\
\hline$\# 16$ & 196.8 & 3.5 & 47.1 & 52.9 & 20.1 & 0.06 \\
\hline$\# 30$ & 1546.7 & 27.6 & 74.8 & 25.2 & 158.0 & 0.50 \\
\hline$\$ 40$ & 617.7 & 11.0 & 85.8 & 14.2 & 63.1 & 0.20 \\
\hline$\# 50$ & 302.5 & 5.4 & 91.2 & 8.8 & 30.9 & 0.10 \\
\hline$\# 80$ & 273.1 & 4.9 & 96.1 & 3.9 & 27.9 & 0.09 \\
\hline$\# 100$ & 64.6 & 1.2 & 97.2 & 2.8 & 6.6 & 0.02 \\
\hline$\# 200$ & 56.8 & 1.0 & 98.3 & 1.7 & 5.8 & 0.02 \\
\hline pan & 34.3 & 0.6 & 98.9 & 1.1 & 3.5 & 0.01 \\
\hline Total & 5575.1 & 99.6 & 98.9 & & 317.5 & 1.00 \\
\hline
\end{tabular}

Init Wt. g

4363.0

Ball Wt. g before wash Dry Wt. after wash

62970

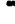
4363.0

\begin{tabular}{|c|c|c|c|c|c|c|}
\hline sieve & WT. & ind $\%$ ret & cum\%ret & cum $\%$ pass & \multirow{6}{*}{ Gilson pan wt. 0} & \multirow[b]{4}{*}{2395.0} \\
\hline 1" & 19.5 & 0.4 & 0.4 & 100.0 & & \\
\hline $3 / 4^{*}$ & 129.0 & 3.0 & 3.4 & 97.0 & & \\
\hline $1 / 2^{\prime \prime}$ & 689.5 & 15.8 & 19.2 & 81.2 & & \\
\hline $3 / 8^{n}$ & 438.0 & 10.0 & 29.2 & 71.2 & & \\
\hline$\# 4$ & 566.5 & 13.0 & 42.2 & 58.2 & & 345.70 \\
\hline$\# 8$ & 111.5 & 2.6 & 44.8 & 55.7 & $w t$ & factor \\
\hline$\# 10$ & 16.6 & 0.4 & 45.2 & 55.3 & 2.4 & 0.01 \\
\hline$\# 16$ & 155.9 & 3.6 & 48.7 & 51.7 & 22.5 & 0.07 \\
\hline$\# 30$ & 1202.0 & 27.5 & 76.3 & 24.2 & 173.5 & 0.50 \\
\hline$\# 40$ & 460.7 & 10.6 & 86.8 & 13.6 & 66.5 & 0.19 \\
\hline$\# 50$ & 227.9 & 5.2 & 92.1 & 8.4 & 32.9 & 0.10 \\
\hline$\# 80$ & 209.2 & 4.8 & 96.9 & 3.6 & 30.2 & 0.09 \\
\hline$\$ 100$ & 49.9 & 1.1 & 98.0 & 2.4 & 7.2 & 0.02 \\
\hline$\# 200$ & 43.6 & 1.0 & 99.0 & 1.4 & 6.3 & 0.02 \\
\hline pan & 24.9 & 0.6 & 99.6 & 0.9 & 3.6 & 0.01 \\
\hline Total & 4344.8 & 99.6 & 99.6 & & 345.1 & 1.00 \\
\hline
\end{tabular}




\begin{tabular}{|c|c|c|c|c|c|c|}
\hline sieve & WT. & ind \%ret & cum\%ret & cum \% pass & \multirow{6}{*}{ Gilson pan wt. G } & \multirow[b]{4}{*}{1736.0} \\
\hline $1^{\prime \prime}$ & 0.0 & 0.0 & 0.0 & 100.0 & & \\
\hline $3 / 4^{n}$ & 24.5 & 0.8 & 0.8 & 99.2 & & \\
\hline $1 / 2^{*}$ & 546.0 & 17.7 & 18.5 & 81.5 & & \\
\hline $3 / 8^{n}$ & 265.0 & 8.6 & 27.1 & 72.9 & & \\
\hline$\# 4$ & 421.0 & 13.7 & 40.8 & 59.2 & & 456.90 \\
\hline$\# 8$ & 88.0 & 2.9 & 43.6 & 56.4 & $w t$ & factor \\
\hline$\# 10$ & 13.7 & 0.4 & 44.1 & 55.9 & 3.6 & 0.01 \\
\hline$\# 16$ & 109.8 & 3.6 & 47.7 & 52.3 & 28.9 & 0.06 \\
\hline$\# 30$ & 859.1 & 27.9 & 75.5 & 24.5 & 226.1 & 0.49 \\
\hline$\# 40$ & 337.8 & 11.0 & 86.5 & 13.5 & 88.9 & 0.19 \\
\hline$\$ 50$ & 172.1 & 5.6 & 92.1 & 7.9 & 45.3 & 0.10 \\
\hline$\# 80$ & 155.4 & 5.0 & 97.1 & 2.9 & 40.9 & 0.09 \\
\hline$\# 100$ & 36.5 & 1.2 & 98.3 & 1.7 & 9.6 & 0.02 \\
\hline$\$ 200$ & 32.3 & 1.0 & 99.4 & 0.6 & 8.5 & 0.02 \\
\hline pan & 18.6 & 0.6 & 100.0 & 0.0 & 4.9 & 0.01 \\
\hline Total & 3079.7 & 100.0 & 100.0 & & 456.7 & 1.00 \\
\hline
\end{tabular}

\begin{tabular}{|c|c|c|c|c|c|c|}
\hline sieve & WT. & ind $\%$ ret & cum\%ret & cum \% pass & \multirow{6}{*}{ Gilson pan w. 0} & \multirow[b]{4}{*}{1259.0} \\
\hline 1 & 0.0 & 0.0 & 0.0 & 100.0 & & \\
\hline $3 / 4$ & 105.5 & 4.4 & 4.4 & 95.6 & & \\
\hline $1 / 2$ & 349.5 & 14.4 & 18.8 & 81.2 & & \\
\hline $3 / 8$ & 293.0 & 12.1 & 30.9 & 69.1 & & \\
\hline 4 & 346.0 & 14.3 & 45.2 & 54.8 & & 319.10 \\
\hline 8 & 64.0 & 2.6 & 47.9 & 52.1 & $w t$ & factor \\
\hline 10 & 11.0 & 0.5 & 48.3 & 51.7 & 2.8 & 0.01 \\
\hline 16 & 81.3 & 3.4 & 51.7 & 48.3 & 20.6 & 0.06 \\
\hline 30 & 646.7 & 25.5 & 77.2 & 22.8 & 156.3 & 0.49 \\
\hline 40 & 243.8 & 10.1 & 87.2 & 12.8 & 61.8 & 0.19 \\
\hline 50 & 123.1 & 5.1 & 92.3 & 7.7 & 31,2 & 0.10 \\
\hline 80 & 113.2 & 4.7 & 97.0 & 3.0 & 28.7 & 0.09 \\
\hline 100 & 29.2 & 1.2 & 98.2 & 1.8 & 7.4 & 0.02 \\
\hline 200 & 26.4 & 1.1 & 99.3 & 0.7 & 6.7 & 0.02 \\
\hline pan & 11.8 & 0.5 & 99.8 & 0.2 & 3.0 & 0.01 \\
\hline Total & 2414.6 & 99.8 & 99.8 & & 318.5 & 1.00 \\
\hline
\end{tabular}




\section{APPENDIX F}

FDOT ATTACHMENT \# 11

\section{CSR RINKER CYLINDER COMPRESSIVE STRENGHT TESTS}




\section{ATTACHMENT 11}

\section{Sweetwater \#87-274 \\ Drill Shaft Concrete Loading Sequence FDOT Concrete}
A) Batch will be initiated with the charging of $50 \%$ to $90 \%$ of the batch water with all of the admixtures.
B) Aggregates will begin charging.
C) After initiation of aggregate charge, cementitious materials will be "ribbon fed" into the aggregate stream. Discharge of the cementitious material will bc complete prior to the completion of the aggregate charge.
D) Truck mixer will move out from under the concrete plant and begin initial mixing of the concrete.
E) Once the initial mixing is complete, the truck mixer will move back under the concrete plant and the balance of the batch water will then be added, via plant water meter, to the mixer. 
Rinker

\section{Cylinder Compressive Strength $\quad 6 " \times 12$ "}

CMEC ACCREDITATION

NO: EN1591

Customer:

Project:

Date: June 29.2001

Contractor:

Plant: 1053 Sweetwater

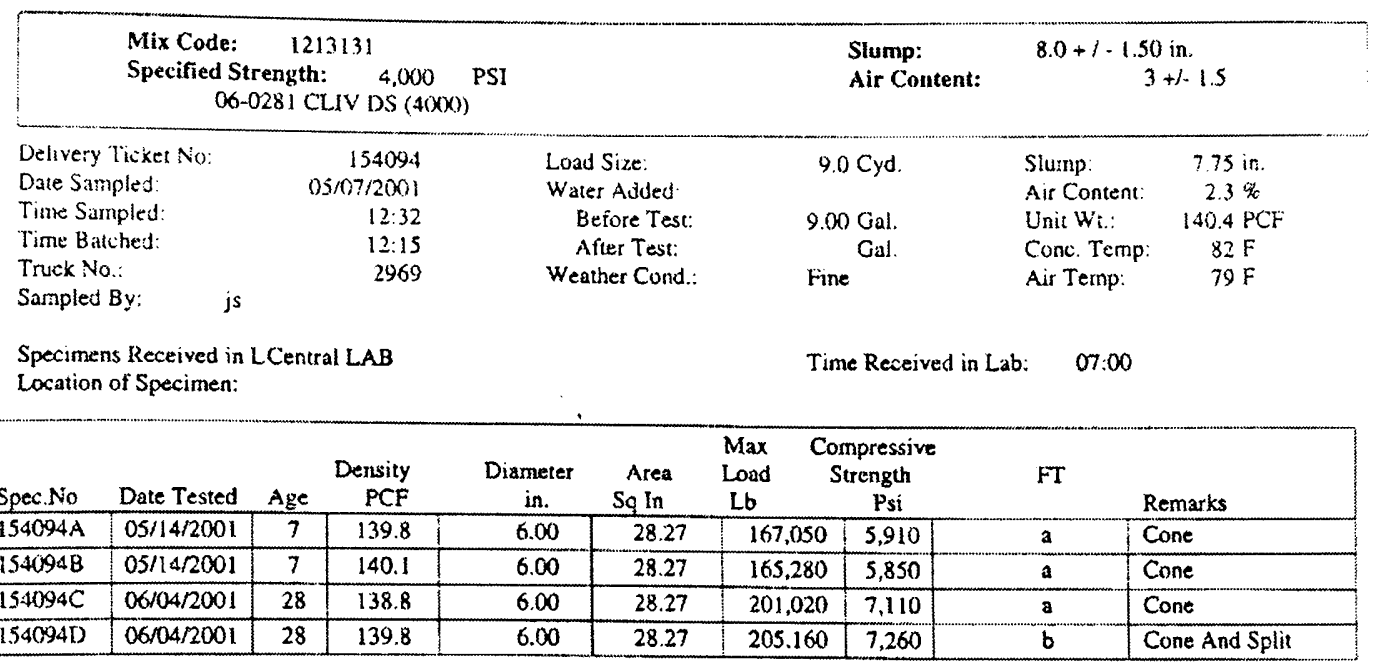

Notes:

1. Sampling, Sperimen Molding, Curing, and Testing have been performed in Accordance with Applicable ASTM Standards andi Methods. uniess otherwise noted.

2. Specimen Consolidition is by rotding unless otherwise noted

3. Specimen Capping is with Sulfur mortar, unless ocherwise noted.

4. Mass per volume hardened concrete was determined in standard moisture condition, uncapped. unless otherwise noted.

5. Fracaire type noted is that shown in ASTM C39 . 9.16 Figure 2.

General Remarks:

Distribution:

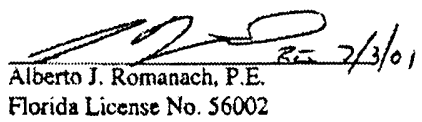

CSR Rinker Marerials Corporation, W.P.B. Laboratory, 1501 Belvedere RA., West Palm Beach, FL 33406, PO Bux 24635, West Palm Beach. FL 33416 Telephone (561) 820-8519 Facsimile (561) 820-8518 


\section{GSR \\ Rinker}

\section{Cylinder Compressive Strength $6 "$ " 12 "}

CMEC ACCREDITATION

NO: EN1591

Customer:

Project:

Date: June 22, 2001

Contractor

Plant: 1053 Sweetwater

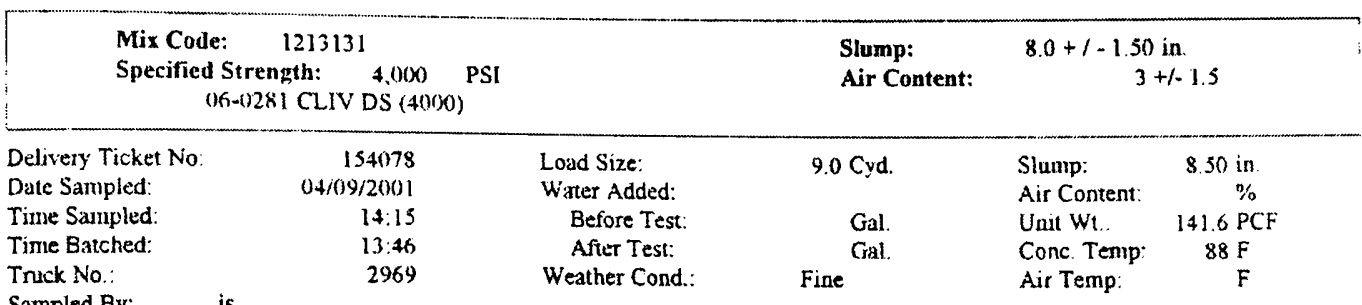

Sampled By: js

Specimens Received in LCentral LAB

Location of Specimen:

Time Received in Lab: $\quad$ 07:00

\begin{tabular}{|c|c|c|c|c|c|c|c|c|c|}
\hline Spec.No & Date Tested & Age & $\begin{array}{r}\text { Density } \\
\text { PCF }\end{array}$ & $\begin{array}{c}\text { Diameter } \\
\text { in. }\end{array}$ & $\begin{array}{l}\text { Area } \\
\text { Sq ln }\end{array}$ & $\begin{array}{l}\text { Max } \\
\text { Load } \\
\text { Lb }\end{array}$ & $\begin{array}{c}\text { ipressive } \\
\text { rength } \\
\text { Psi }\end{array}$ & $\mathrm{FT}$ & Remarks \\
\hline $154078 \mathrm{~A}$ & $04 / 16 / 2001$ & 7 & 140.3 & 6.00 & 28.27 & 164,100 & 5,800 & a & Cone \\
\hline $154078 \mathrm{~B}$ & $04 / 16 / 2001$ & 7 & 139.8 & 6.00 & 28.27 & 162,030 & 5,730 & a & Cone \\
\hline $154078 \mathrm{C}$ & $05 / 07 / 2001$ & 28 & 141.1 & 6.00 & 28.27 & 223,330 & 7,900 & a & Cone \\
\hline $154078 D$ & $05 / 07 / 200 !$ & 28 & 140.3 & 6.00 & 28.27 & 216,190 & 7,650 & a & Cone \\
\hline
\end{tabular}

Notes:

1. Sampling, Specimen Molding , Curing, and Testing have been periormed in Accordance with Applicable ASTM Standards and Methods, unless otherwise noted

2 Specirren Consolidation is by rodding unless otherwise noted.

3. Specimen Capping is with Sulfur mortar, unless otherwise noted.

4. Mass per volume hardened concrete was determined in saandard moisture condition, unkapped, unless otherwise noted.

5. Fracture type noted is that shown in AS7M C39-9.16 Figure 2

General Remarks:

Distribution:

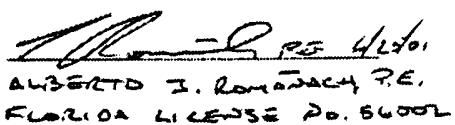

CSR Rinker Materials Corporation, W.P.B. Laboratory, 1501 Belvedere Rd., West Palm Beach, fil 33406, PO Box 24635, West Palm Beach, Fl. 33416 Telę̧hone (56i) 820-8519

Facsimile (561) 820-8518 


\section{GSR \\ Rinker}

\section{Cylinder Compressive Strength}

\section{CMEC ACCREDITATION}

NO: EN1591

\section{Customer:}

Project:

Contractor:

Date: June 29,2001

Plant: 1053 Sweetwater

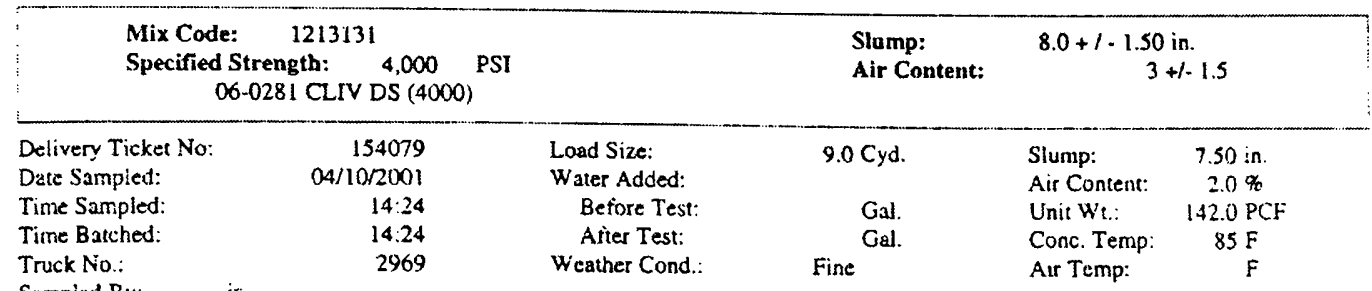

Sampled By: js

Specimens Received in LCentral LAB Location of Specimen:

Time Received in Lab: $\quad$ 07:00

\begin{tabular}{|c|c|c|c|c|c|c|c|c|c|}
\hline Spec.No & Dace Tested & Age & $\begin{array}{r}\text { Density } \\
\text { PCF }\end{array}$ & $\begin{array}{c}\text { Dianseter } \\
\text { in. }\end{array}$ & $\begin{array}{l}\text { Area } \\
\mathrm{Sq} \text { In }\end{array}$ & $\begin{array}{l}\text { Max } C \\
\text { Load } \\
\text { Lb }\end{array}$ & $\begin{array}{l}\text { mpressive } \\
\text { itrength } \\
\text { Psi }\end{array}$ & FT & Remark \\
\hline $154079 \mathrm{~A}$ & $04 / 17 / 2001$ & 7 & 140.6 & 6.00 & 28.27 & 168.670 & 5,970 & $a$ & Cone \\
\hline $154079 \mathrm{~B}$ & $04 / 17 / 2001$ & 7 & 141.6 & 6.00 & 28.27 & 166,460 & 5.890 & a & Cone \\
\hline $154079 \mathrm{C}$ & $05 / 08 / 2001$ & 28 & 140.6 & 6.00 & 28.27 & 206,630 & 7,310 & $\mathbf{a}$ & Cone \\
\hline $154079 D$ & $05 / 08 / 2001$ & 28 & 140.8 & 6.00 & 28.27 & 204,710 & 7,240 & $\bar{a}$ & Cone \\
\hline
\end{tabular}

Notes:

1. Sampling. Specimen Molding . Curing, and Testing bave been perforned in Accordance with Applicable ASTM Standards and Methods, unless otherwise noted.

2. Specimen Consolidation is by rodding unless otherwise noted.

3. Specimen Capping is with Sulfur mortar, unless otherwise noted.

4. Mass per volume hardened conerele was determined in standard moisture condition, uncapped. urless otherwise noted.

5. Fracture type noced is that shown in ASTM C39 - 9.16 Figure 2.

General Renurks:

Distribution:

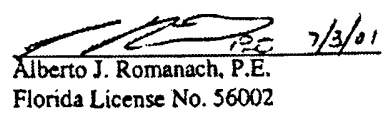

CSR Rinker Materials Comporation. W.P.B. Laboratory. 1501 Belvedere Rd., West Palm Besch, FL 33406, PO Box 24635, West Palm Beach, FL 33416 Teleptone (561) 820-8519

Facsimile (561) 820-8518 


\section{GSR \\ Rinker}

\section{Cylinder Compressive Strength $\quad 6^{\prime \prime} \times 12^{\prime \prime} \quad$ CMEC ACcRedration \\ NO: EN1591}

Customer:

Project:

Date: June 29, 2001

Contractor:

Plant: 1053 Sweetwater

\begin{tabular}{|c|c|c|c|c|c|}
\hline $\begin{array}{l}\text { Mix Code: } \\
\text { Specified Strengt } \\
06-0281\end{array}$ & $\begin{array}{l}213131 \\
\text { th: } \quad 4,000 \\
\text { CLIV DS }(4000)\end{array}$ & PSI & $\begin{array}{l}\text { Slump: } \\
\text { Air Content: }\end{array}$ & $8.0+1-1.50$ & 1.1 .5 \\
\hline $\begin{array}{l}\text { Delivery Ticket No: } \\
\text { Date Sampled: } \\
\text { Time Sampled: } \\
\text { Time Batched: } \\
\text { Truck No.: }\end{array}$ & $\begin{array}{r}154080 \\
04 / 10 / 2001 \\
15: 25 \\
15: 25 \\
2969\end{array}$ & $\begin{array}{l}\text { Load Size: } \\
\text { Water Added: } \\
\text { Before Test: } \\
\text { After Test: } \\
\text { Weather Cond:: }\end{array}$ & $\begin{array}{l}9.0 \mathrm{Cyd} . \\
\text { Gal. } \\
\text { Fine }\end{array}$ & $\begin{array}{l}\text { Slump: } \\
\text { Air Content: } \\
\text { Vnit We.: } \\
\text { Conc. Temp: } \\
\text { Air Temp: }\end{array}$ & $\begin{array}{c}7.75 \text { in. } \\
2.0 \% \\
142.0 \mathrm{PCF} \\
82 \mathrm{~F} \\
\mathrm{~F}\end{array}$ \\
\hline
\end{tabular}

Sampled By:

Specimens Received in LCentral LAB

Location of Specimen:

Time Received in Lab: $\quad$ 07:00

\begin{tabular}{|c|c|c|c|c|c|c|c|c|c|}
\hline Spec. No & Date Tested & Age & $\begin{array}{r}\text { Density } \\
\text { PCF } \\
\end{array}$ & $\begin{array}{c}\text { Diameter } \\
\text { in. } \\
\end{array}$ & $\begin{array}{c}\text { Area } \\
\text { Sq In }\end{array}$ & $\begin{array}{l}\text { Max } \\
\text { Load } \\
\text { Lb }\end{array}$ & $\begin{array}{l}\text { mpressive } \\
\text { trength } \\
\text { Psi }\end{array}$ & FT & Remarks \\
\hline $154080 \mathrm{~A}$ & $04 / 17 / 2001$ & 7 & 143.9 & 6.00 & 28.27 & 170,590 & 6,030 & a & Cone \\
\hline $154080 \mathrm{~B}$ & $04 / 17 / 2001$ & 7 & 143.9 & 6.00 & 28.27 & 168.380 & 5,960 & $\bar{a}$ & Cone \\
\hline $154080 \mathrm{C}$ & $05 / 08 / 2001$ & 28 & 140.6 & 6.00 & 28.27 & 219,480 & 7,760 & $\mathbf{a}$ & Cone \\
\hline $154080 \mathrm{D}$ & $05 / 08 / 2001$ & 28 & 140.6 & 6.00 & 28.27 & 210,330 & 7.440 & c & Cone And Shear \\
\hline
\end{tabular}

Notes:

1. Sampling. Specimen Molding. Curing. and Testing have been periormed in Accordance with Applicable ASTM Standards and Methods. unless otherwise noted.

2. Specimen Consolidation is by rodding unless otherwise noted.

3. Specimen Capping is with Sulfur mortar. unless otherwise noted.

4. Mass per volume hardened concrete was determined in standard moisture condition, uncapped, unless otherwise noted.

5. Fracture type noted is that shown in ASTM C39 - 9.16 Figure 2.

General Remarks:

Distribution:

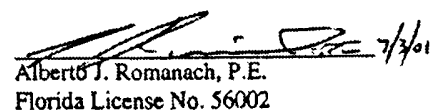

CSR Ririker Materials Corporation, W.P.B. Laboratory, 1 S01 Belvedere Rd., West Palm Beach, FL 33406, PO Box 24635. West Pelm Beach, FL 33416 Telephone (561) 820-8519 Facsitnile (561) 820-8518 
Cylinder Compressive Strength $\quad 6 " \times 12 "$

Project:

Contractor:
CMEC ACCREDTTATION

NO: EN1591

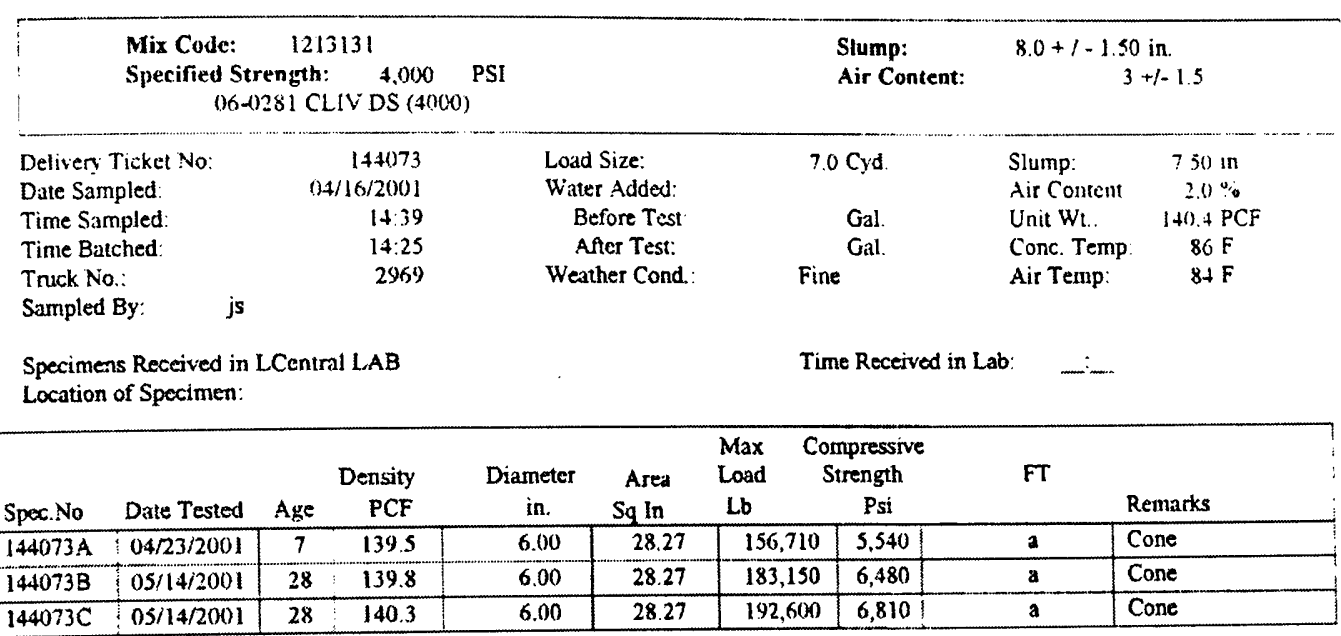

Notes:

1. Sampling, Specimen Molding, Curing, and Testing have been performed in Accordance with Applicable ASTM Standards and Methods, unless otherwise noted.

2. Specimen Consolidation is by rodding unless otherwise noted

3. Specimen Cappinz is with Sulfur mortar, unless otherwise noted.

4. Mass per volume hardetted concrete was deternined in standard moisture condition, uncapped, unless otherwiste noted.

5. Fracture cype noted is that shown in ASTM C39-9.10 Figure 2.

General Remarks:

Distribution:

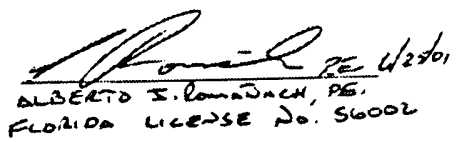

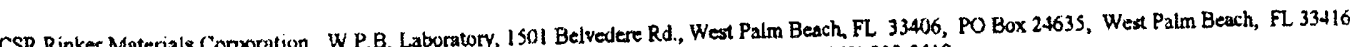
Telephone (561) 820-8519 Facsimile (561) 820-8518 


\section{CSSR \\ Rinker}

Cylinder Compressive Strength 6" x 12"

CMEC ACCREDITATION

NO: EN1591

Customer:

Project:

Contractor:

Date: June 29,2001

Plant: 1053 Sweetwater

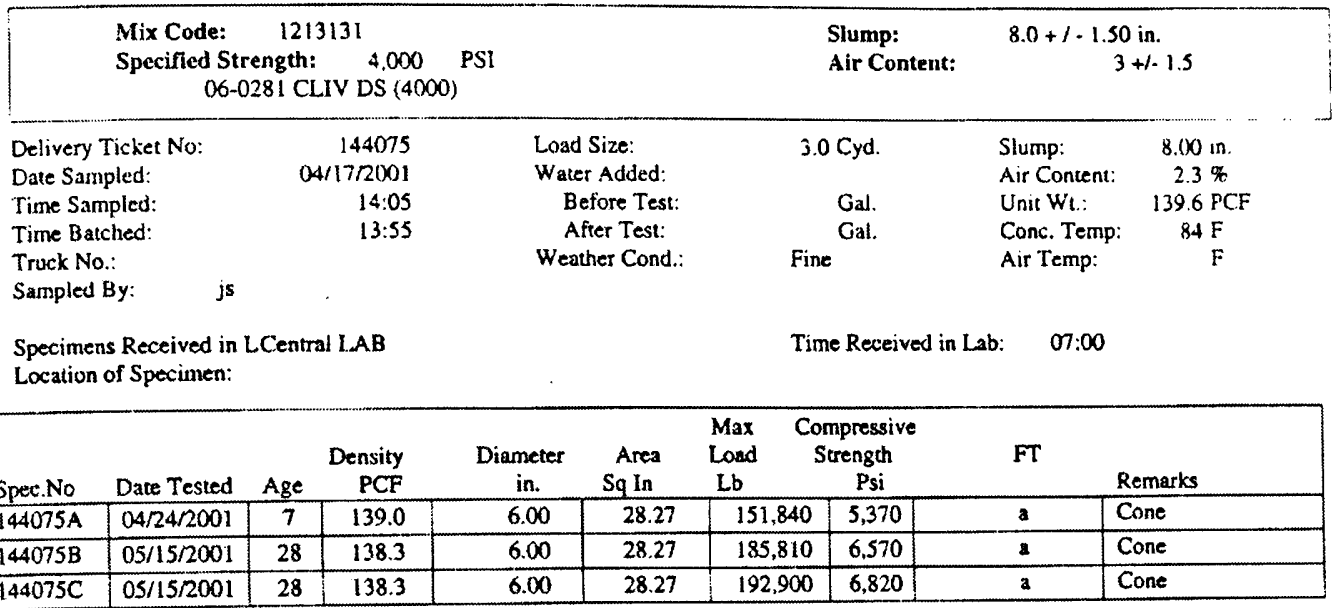

Notes:

1. Sampling, Specimen Molding, Curing, and Testing have been performed in Accordance with Applicable ASTM Standards and Methods, unless otherwise noted.

2. Specimen Consolidation is by rodding unjess otherwise noted.

3. Specimen Capping is with Sulfur mortar, unless otherwise noted.

4. Mass per volume hardened concrete was deternined in standard moisture condition, uncapped, unless otherwise noted.

5. Fracture type noted is that shown in ASTM C39-9.16 Figure 2.

General Remarks:

Distribution:

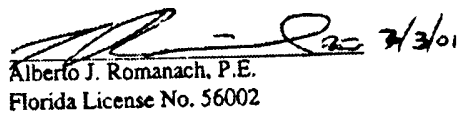

CSR Rinker Macerials Comocation, W.P.B. Laboratory, 1501 Belvedere Rd., West Paim Beach, FL 3340x. PO Box 24635. West Palm Beach, FL. 33416 Telephone (561) 820-8519

Facsimile (561) 820-8518 
Rinker

\section{Cylinder Compressive Strength 6" x 12" CMEC ACCREdrtation \\ NO: EN1591}

Customer:

Project:

Date: June 29, 2001

Contractor:

\begin{tabular}{|c|c|c|c|c|c|}
\hline $\begin{array}{l}\text { Mix Code: } \\
\text { Specified Strengt } \\
06-0281\end{array}$ & $\begin{array}{l}213131 \\
\text { th: } \quad 4,000 \\
\text { CLIV DS }(4000)\end{array}$ & PSI & $\begin{array}{l}\text { Slump: } \\
\text { Air Content: }\end{array}$ & $8.0+1-1.50$ & $\frac{n}{1.5}$ \\
\hline Delivery Ticket No: & 144076 & Load Size: & $9.0 \mathrm{Cyd}$. & Slump: & $7.50 \mathrm{in}$ \\
\hline Date Sampled: & $04 / 17 / 2001$ & Water Added: & & Air Content: & $2.0 \%$ \\
\hline Time Sampled: & $15: 00$ & Before Test: & Gal. & Untt Wt: & $140.8 \mathrm{PCF}$ \\
\hline Time Batched: & $14: 47$ & After Test: & Gal. & Conc. Temp: & $83 \mathrm{~F}$ \\
\hline Truck No.: & 2969 & Weather Cond: & Fine & Air Temp: & $\mathrm{F}$ \\
\hline
\end{tabular}

Sampled By: is

Specimens Received in LCeniral LAB

Location of Specimen:

\begin{tabular}{|c|c|c|c|c|c|c|c|c|c|}
\hline Spec.No & Date Tested & Age & $\begin{array}{r}\text { Density } \\
\text { PCF }\end{array}$ & $\begin{array}{c}\text { Dianleter } \\
\text { in. }\end{array}$ & $\begin{array}{l}\text { Area } \\
\mathrm{Sq} \text { In }\end{array}$ & $\begin{array}{l}\text { Max } \\
\text { Load } \\
\text { Lb }\end{array}$ & $\begin{array}{l}\text { mpressive } \\
\text { trength } \\
\text { Psi }\end{array}$ & FT & Remarks \\
\hline $144076 \mathrm{~A}$ & $04 / 24 / 2001$ & 7 & 141.1 & 6.00 & 28.27 & 154,940 & 5,480 & 2 & Cone \\
\hline $144076 \mathrm{~B}$ & $05 / 15 / 2001$ & 28 & 140.8 & 6.00 & 28.27 & 192,010 & 6,790 & $a$ & Cone \\
\hline $144076 \mathrm{C}$ & $05 / 15 / 2001$ & 28 & 139.5 & 6.00 & 28.27 & 189,350 & 6.700 & $a$ & Cone \\
\hline
\end{tabular}

Notes:

1. Sampling. Specimen Molding, Curing, and Testing have been periormed in Accordance with Applicable ASTM Standards and Methods, unless otherwise noted.

2. Specimen Consolidation is by rodding unless otherwise noted.

3. Specimen Capping is with Sulfur mortar, unless otherwise noted.

4. Mass per volume hardened concrete was determined in standard moisture condition, uncapped, unless otherwise nuted.

5. Fracture rype noted is that shown in ASTM C.39 9.16 Figure 2.

General Remarks:

Distribution:

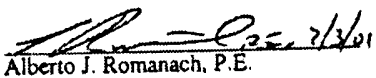

Florida License No. 56002

CSR Rinter Marerials Corporition Telephone (561) 820-8519 Factimile (561) 820-8518 


\section{CSR \\ Rinker}

\section{Cylinder Compressive Strength $6 "$ " $12 "$ CMEC ACCREDITATION}

\section{Customer:}

Date: June 22.20011

Project:

Plant: 1053 Sweetwater

Contractor:

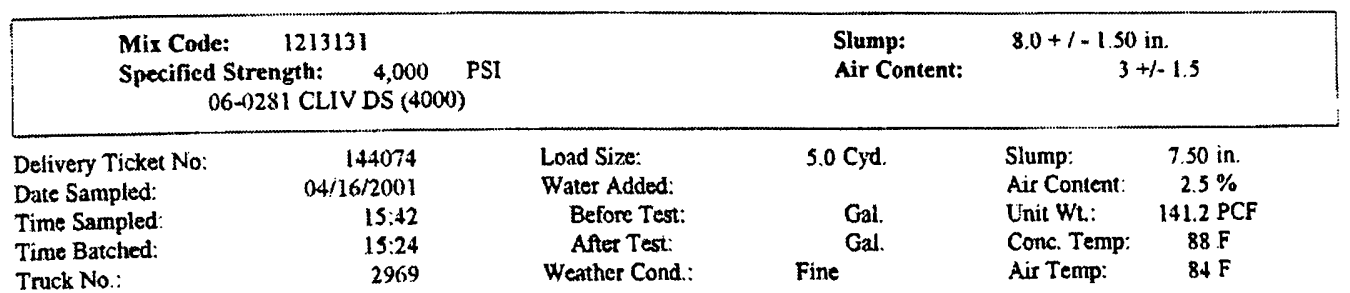

Sampled By:

js

Time Received in Lab: $\quad 07: 00$

Specimens Received in LCentral LAB

Location of Specimen:

\begin{tabular}{|c|c|c|c|c|c|c|c|c|c|}
\hline Spec. No & Date Tested & Age & $\begin{array}{r}\text { Derisity } \\
\text { PCF }\end{array}$ & $\begin{array}{c}\text { Dianneter } \\
\text { in. }\end{array}$ & $\begin{array}{l}\text { Area } \\
\text { Sq In }\end{array}$ & $\begin{array}{l}\text { Max } \\
\text { Load } \\
\text { Lb }\end{array}$ & $\begin{array}{l}\text { ompressive } \\
\text { Strength } \\
\text { Psi }\end{array}$ & $\mathrm{FT}$ & Remarks \\
\hline $144074 \mathrm{~A}$ & $04 / 30 / 2001$ & 14 & 138.3 & 6.00 & 28.27 & 184,180 & 6,510 & a & Cone \\
\hline $144074 \mathrm{~B}$ & $05 / 14 / 2001$ & 28 & 139.0 & 6.00 & 28.27 & 193,640 & 6,850 & a & Cone \\
\hline $144074 C$ & $05 / 1+12001$ & 28 & 139.3 & 6.00 & 28.27 & 185,360 & 6,560 & a & Cone \\
\hline
\end{tabular}

Notes:

1. Sampling Specimen Molding, Curing, and Testing bave been performed in Accordance with Applicable ASTM Standurds and Methods, unlexs otherwise noted.

2. Specimen Consolidation is by rodding unless otherwise noted.

3. Specimen Capping is with Sulfur mortar, unless otherwise noted.

- Mass per polume hardened concrete was determined in standard moisture condition, uncapped, unless otherwise noted.

5. Fracture type noted is that shown in ASTM C39 - 9.16 Figure 2.

General Remarks:

Distribution:

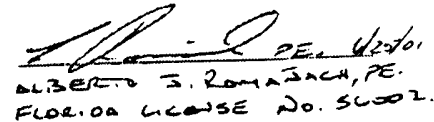

Laboratory, 1501 Belvedere Rd, West Palm Beach, FL 33406, PO Box 24635. West Palm Beach. FL 3341t CSR Rinker Materials Corporation, W P.B Luboratory, 1501 Belvedere Rd, Facsimile (561) $820-8518$ 


\section{CSI \\ Rinker}

\section{Cylinder Compressive Strength}

$6 " \times 12 "$
CMEC ACCREDTTATION

NO: EN1591

\section{Customer:}

Project:

Dute: June 22, 2001

Contractor:

Plant: 1053 Sweetwater

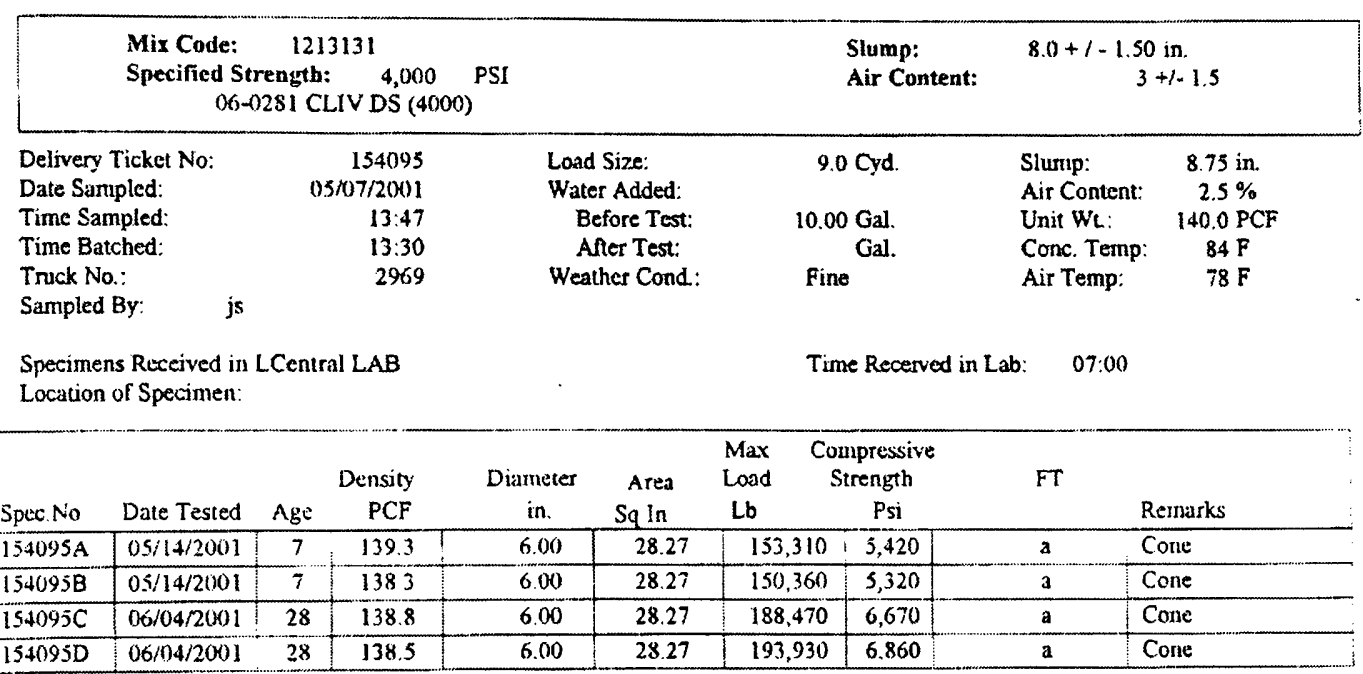

Notes:

1. Sarnpling. Specimen Molding, Curing, and Testing huve heen periormed in Accordance with Applicable ASTM Standards and Methods, unless otherwise noted.

2. Specimen Consolidation is by rodiding unless otherwise noted.

3. Specirmen Capping is with Sulfur mortar, unless otherwise noted.

4. Mass per volume hardented concrete was determined in standard moisture condition, uncapped, unless otherwhse noted.

5. Fracture type noted is thal shown in ASTM C39 - 9.16 Figure 2 .

\section{General Remarks:}

Distribution:

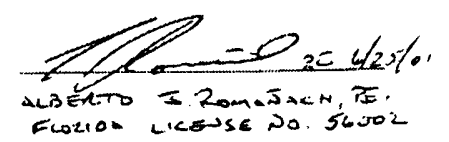

CSR Rinker Materials Corporation, W.P B. Laboratory, 1501 Belvedere Rd, West Palm Besch, FL 33406, PO Box 24635, West Palm Beach. FL 33416 Telephne (561) 820-8519 Facsimile (561) 820-8518 
Rinker

\section{Cylinder Compressive Strength \\ $6 " \times 12 "$}

CMEC ACCREDITATION

Customer:

Project:

Date: June 22, 2001

Contractor:

Plant: 1053 Sweetwater

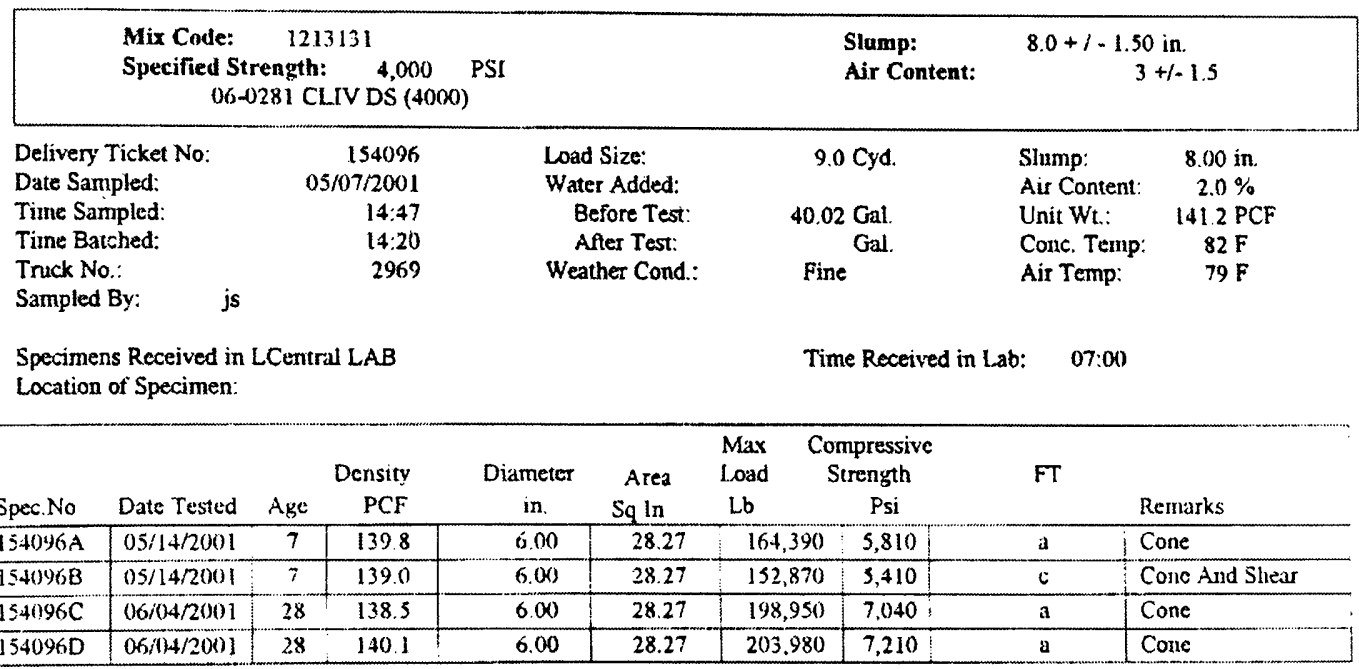

Notes:

1. Sampling, Specimen Molding , Curing, and Testing huve been perfurmed in Accordance with Applicable ASTM Standards and Methods, unless otherwise noted.

2. Specimen Consolidation is by rodding unless otherwise noted.

3. Specimen Capping is with Sulfur mortar. unless otherwise noted.

4. Mass per volume burtened concrete was determined in standard moisture condition, uncupped, unless otherwise noted.

5. Fracture type noted is that shown in ASTM C39 - 9.16 Figure 2.

General Remarks:

Distribution:

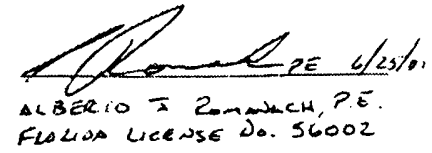

CSR Rinker Materials Corporation, W.P.B. Laboratory. 1501 Belvedere Rd., West Palm Beach, FL 33406, PO Box 24635, West Palm Beath, fL 334:t Teiephone (561) 820-8519 Facsimile (561) $820-8518$ 